Sheila Fernandes Pimenta e Oliveira Vânia de Fátima Martino Genaro Alvarenga Fonseca (org.)

\title{
Educação e Políticas Públicas em Viéses Interdisciplinares
}

Coleção Educação e Educandos
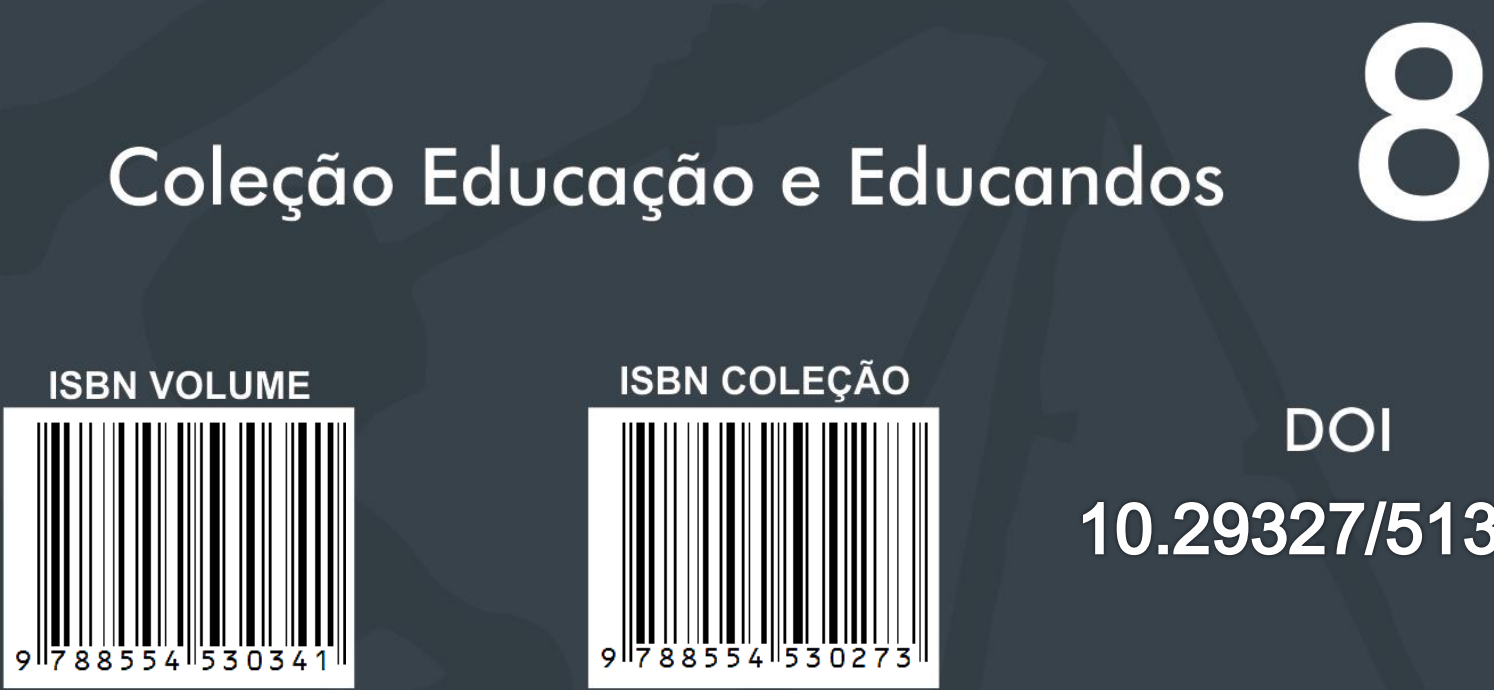

\author{
DOI \\ $10.29327 / 513196$
}

unesp UnifACEF 


\section{EDUCAÇÃO E POLÍTICAS PÚBLICAS EM VIÉSES INTERDISCIPLINARES}


EDUCAÇÃO E POLÍTICAS PÚBLICAS EM VIESES

Sheila Fernandes Pimenta e Oliveira

Vânia de Fátima Martino

Genaro Alvarenga Fonseca

Tatiana Noronha de Souza (org.)

\section{EDUCAÇÃO E POLÍTICAS PÚBLICAS EM VIÉSES INTERDISCIPLINARES}

ISBN 978-85-5453-034-1 


\section{9 \\ Comissão Científica}

Alessandra David (Centro Universitário Moura Lacerda)

Ana Lúcia Furquim Campos-Toscano (Uni-FACEF)

Célia Maria David (UNESP)

Fernando Silva Ribeiro (Universidade Estadual de Goiás)

Genaro Alvarenga Fonseca (UNESP)

Hilda Maria Gonçalves da Silva (UNESP)

Joana Correa Goulart (Universidade Estadual de Goiás)

Karina de Melo Conte (Centro Universitário Claretiano)

Karina Elizabeth Serrazes (Centro Universitário Claretiano)

Lucinda de Fátima Maria Coelho Rodrigues (Uni-FACEF)

Lucimary Bernabé Pedrosa de Andrade (FFCL)

Márcia Pereira da Silva (UNESP)

Maria Eloísa de Souza Ivan (Uni-FACEF)

Maria Madalena Graciloi (FFCL)

Maria Sílvia Pereira Rodrigues Alves Barbosa ((Uni-FACEF)

Pricila Bertanha (Centro Universitário Claretiano)

Sheila Fernandes Pimenta e Oliveira (Uni-FACEF)

Sílvia Regina Viel (Uni-FACEF)

Sílvio Carvalho Neto (Uni-FACEF)

Vânia de Fátima Martino (UNESP)

Tatiana Noronha de Souza (UNESP)

Welton Roberto Silva (Uni-FACEF)

\section{Conselho Editorial}

Ana Cláudia da Silva (UnB)

Antônio Carlos Petean (UFU)

Daniela Melaré Vieira Barros - Universidade Aberta / Portugal

Danilo Seithi Kato (UFTM)

Genaro Alvarenga Fonseca (UNESP)

Sheila Fernandes Pimenta e Oliveira ((Uni-FACEF)

Sílvio Carvalho Neto (Uni-FACEF)

Teise de Oliveira Guaranha Garcia - FFCLRP / USP

Vânia de Fátima Martino (UNESP) 
EDUCAÇÃO E POLÍTICAS PÚBLICAS EM VIESES

Un̈-FACE INTERDISCIPLINARES

Centro Universitário Municipal de Franca ISBN: 978-85-5453-018-1

(C) 2019 dos autores

Direitos de publicação Uni-FACEF

www.unifacef.com.br

Coleção: Educação e Educandos, v.8. 


\section{Uni-FACEF \\ EDUCAÇÃo E POLÍtICAS PÚBLICAS EM VIESES \\ INTERDISCIPLINARES \\ ISBN: 978-85-5453-018-1

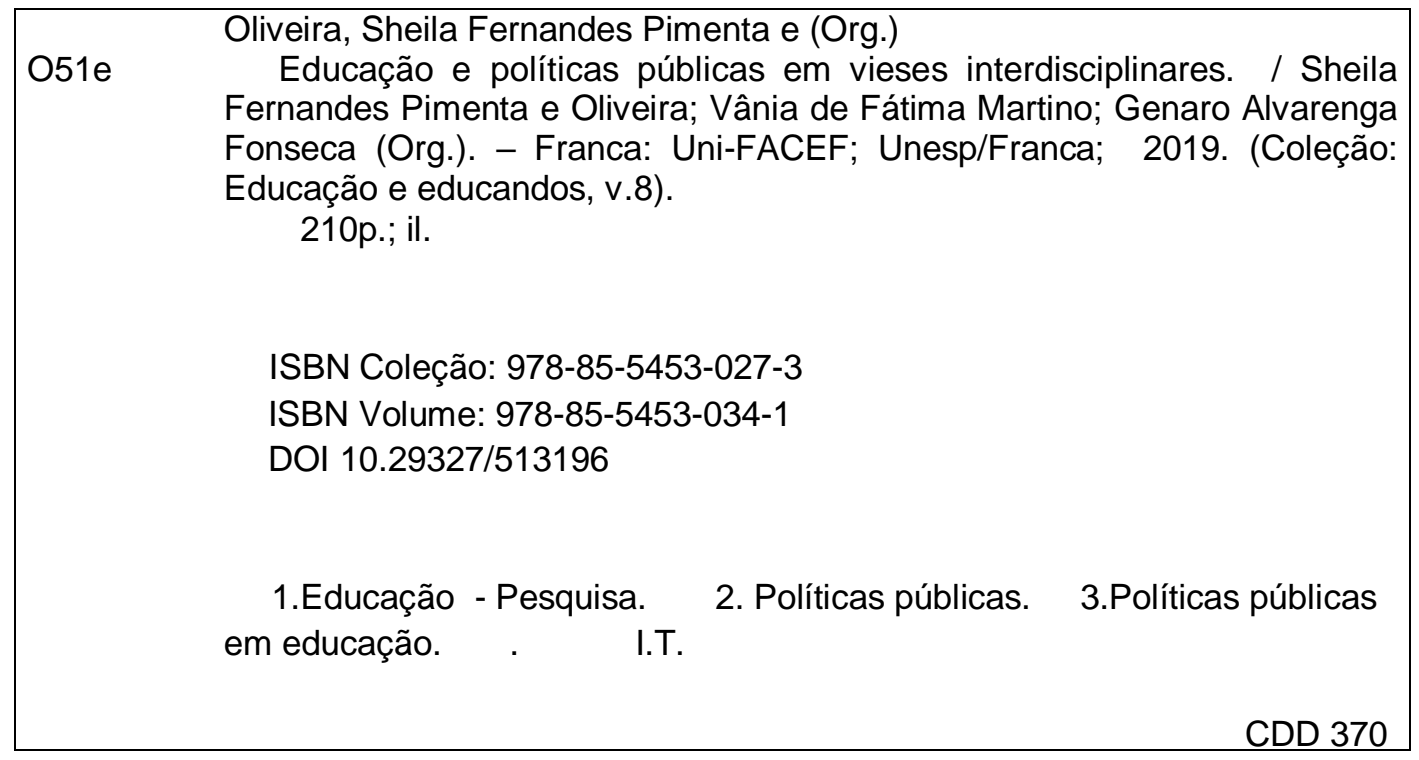

TODOS OS DIREITOS RESERVADOS.

É proibida a reprodução total ou parcial, de qualquer forma ou por qualquer meio. A violação dos direitos de autor (lei no. 9.610/98) é crime estabelecido pelo artigo 184 do código Penal. Todo o conteúdo apresentado neste livro é de responsabilidade exclusiva de seus autores.

Editora Uni-FACEF Centro Universitário Municipal de Franca

Associada à ABEC - Associação Brasileira de Editores Científicos 


\section{PREFÁCIO}

Para se pensar sobre a construção de saber, seguramente, exige-se um olhar para um processo flexível, que transita da humanidade à tecnologia, da emoção à razão, do senso comum à sistematicidade, em múltiplas idas e vindas. Assim, o conhecimento se faz em um contexto dinâmico, e sempre em movimento.

Também é essencial traçar um caminho, em perspectiva histórica, trazendo o passado, para pensar sobre a escola, o ensino e a relação deles com os indivíduos e com as demandas sociais. Objetivos educacionais, conteúdos de ensino, diversidade de metodologia e complexidade de processos avaliativos integram passado, presente e futuro, porque são os elos que agregam as discussões temporais, em educação formal, e podem ser lidos nos diversos textos publicados aqui.

No presente e-book, os textos correlacionam as dimensões das políticas públicas e educacionais, considerando as fundamentações teóricas e vivenciais de estratégias e ações governamentais, para responder aos problemas contemporâneos, nos âmbitos sociais, econômicos, culturais etc..

Não se pode deixar de tratar sobre os atores sociais, que são investigados e descritos, nos diversos capítulos do e-book. Os atores participam do planejamento, elaboração, aplicação e avaliação das diversas políticas públicas brasileiras do âmbito educacional. Aparecem em perfis individuais, mas ainda aparecem em ações coletivas, para que as políticas públicas tenham efeito.

As temáticas chamam atenção para a leitura, porque perpassam pela distribuição de renda, no contexto escolar, pela formação de professores, pelas avaliações externas às escolas, e pelas alterações promovidas nos currículos, especialmente, nas alterações trazidas pela Base Nacional Comum Curricular - BNCC. Também são focadas políticas que asseguram os direitos humanos e educação para a diversidade. Enfim, temas que buscam respostas para os problemas atuais e demonstram a postura científica, diante das políticas públicas.

Nesse sentido, aqueles que se interessam pela defesa da educação formal brasileira têm muitos motivos para folhear e estudar as discussões apresentadas, seja para concordar ou discordar, seja para continuar.

Fica, assim, um convite à leitura, à reflexão e a outra ação.

Prof $^{a}$ Dr$^{\mathrm{a}}$ Sheila Fernandes Pimenta e Oliveira

Pró-Reitora Acadêmica e Docente Centro Universitário Municipal de Franca - Uni-FACEF 


\section{SUMÁRIO}

A EDUCAÇÃO AMBIENTAL PRATICADA EM UMA ESCOLA PÚBLICA DE ENSINO FUNDAMENTAL II DE UM MUNICÍPIO DO INTERIOR DE SÃO PAULO

A EDUCAÇÃO INFANTIL NO BRASIL: A trajetória de conquistas e desafios 28 ACOLHIMENTO COMO ESTRATÉGIA PARA PROMOÇÃO DA SAÚDE E QUALIDADE DE VIDA DE PESSOAS EM SITUAÇÃO DE RUA .

ARQUITETURA E EDUCAÇÃO: A função social da arquitetura e seu aporte aos espaços educativos

CONSELHOS MUNICIPAIS DE EDUCAÇÃO: AVANÇO DAS POLÍTICAS PÚBLICAS EDUCACIONAIS?

EDUCAÇÃO E DIÁLOGOS INTERGERACIONAIS: O processo de envelhecimento e velhice para crianças e adolescentes

ESTUDANTES DO ENSINO MÉDIO: Perspectivas e relação com a universidade

JUVENTUDE E OS PROGRAMAS DE APRENDIZAGENS: O QUE DIZEM AS PESQUISAS?

NOVO OLHAR NO PAPEL DO SERVIÇO SOCIAL NA SAÚDE: A EDUCAÇÃO INTERPROFISSIONAL.

PERSPECTIVAS EM DISPUTA: Olhares das trabalhadoras do sexo de Franca sobre a violência sexual e o estupro

POLÍTICA PÚBLICA MULTICÊNTRICA: Conceito e indicadores como contribuição crítica da realidade educacional brasileira

POLÍTICAS EDUCACIONAIS NO BRASIL: Da gênese à

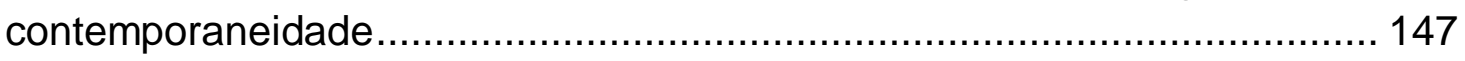

POLÍTICAS PÚBLICAS A SERVIÇO DO CIVILIZAR: Os excluídos da Primeira república. Franca-SP

POLÍTICAS PÚBLICAS EDUCACIONAIS EM UBERABA NO INÍCIO DA DÉCADA DE 1930: Alguns apontamentos

POLÍTICAS PÚBLICAS, EDUCAÇÃO E DIREITOS HUMANOS: o Memorial da Resistência de São Paulo

UMA ANÁLISE DE DADOS COLETADOS NAS UNIVERSIDADES SOBRE RELACIONAMENTOS ÍNTIMOS ABUSIVOS

ÍNDICE 


\title{
A EDUCAÇÃO AMBIENTAL PRATICADA EM UMA ESCOLA PÚBLICA DE ENSINO FUNDAMENTAL II DE UM MUNICÍPIO DO INTERIOR DE SÃO PAULO
}

\author{
SILVA JUNIOR, Adolfo Domingos da \\ Mestrando - UNESP Franca/SP \\ adolfodsj@yahoo.com.br \\ FONSECA, Genaro Alvarenga \\ Docente - UNESP- Franca/SP \\ ga.fosenca@unesp.br
}

\section{INTRODUÇÃO}

A inquietação mundial com a crise socioambiental saiu do círculo de ambientalistas e ecologistas para envolver não só os governos, mas também, as organizações e a sociedade civil na busca de alternativas que cessem ou diminuam esse problema e, também, visando a preservação do planeta e da vida humana.

Segundo Dias (1991, p. 4), durante a realização da Conferência da Organização das Nações Unidas (ONU) sobre o Meio Ambiente Humano, realizada em Estocolmo no ano de 1972 e que objetivava a preservação e a melhoria do ambiente urbano, os países membros editaram a Recomendação $n^{\circ} 96$, reconhecendo o "[...] desenvolvimento da EA como o elemento crítico para o combate à crise ambiental" (DIAS, 2004, p. 79), entretanto os representantes do Brasil

[...] afirmaram que o país não se importaria em pagar o preço da degradação ambiental, desde que o resultado fosse o aumento do Produto Nacional Bruto (PNB). Um cartaz anunciava: 'Bem-vindos à poluição, estamos abertos para ela. O Brasil é um país que não tem restrições. Temos várias cidades que receberiam de braços abertos a sua poluição, porque o que nós queremos são empregos, são dólares para o nosso desenvolvimento" (DIAS, 1991, p. 4).

À época o Brasil se posicionou contrariamente aos demais países, pois "viram na Conferência indício de tentativas de aborto do desenvolvimento dos países pobres, através do controle ambiental" (DIAS, 1991, p. 4).

Entretanto, a pressão exercida pelos movimentos ambientalistas e ecológicos nacionais, juntamente com o quanto discutido nos eventos internacionais, apontaram a crise ambiental como relevante questão de interesse público, demandando atitudes por parte do governo, surgindo então a EA no Brasil com a criação da Secretaria Especial do Meio Ambiente (SEMA), através do Decreto no 73.030/73, a quem competia, entre outros assuntos relacionados ao meio ambiente, 
[...] i) promover, intensamente, através de programas em escala nacional, o esclarecimento e a educação do povo brasileiro para o uso adequado dos recursos naturais, tendo em vista a conservação do meio ambiente" (BRASIL, 1973).

A Conferência de Tbilisi1 foi a responsável pela elaboração dos objetivos, características, definições, princípios, estratégias e ações orientadoras da EA, tanto em nível nacional quanto internacional, e também por realçar seu caráter interdisciplinar, crítico, ético e transformador. Naquela oportunidade, ainda se deliberou que para a implementação de uma EA efetiva, necessário considerar todos os aspectos que compõem a questão ambiental, a saber: os aspectos políticos, sociais, econômicos, científicos, tecnológicos, culturais, ecológicos e éticos.

Por força dos movimentos internacionais nas décadas de 70 e 80, que enfatizaram a qualidade de vida e a preservação de patrimônio natural, editou-se a Lei $n^{\circ}$ 6.938/81, que instituiu a Política Nacional do Meio Ambiente (PNMA), objetivando

"a preservação, melhoria e recuperação da qualidade ambiental propícia à vida, visando assegurar, no País, condições ao desenvolvimento sócio-econômico, aos interesses da segurança nacional e à proteção da dignidade da vida humana" (BRASIL, 1981).

A Constituição Federal de 1988 (CF) dedicou um capítulo especialmente ao Meio Ambiente, conferindo aos cidadãos o "direito ao meio ambiente ecologicamente equilibrado" (BRASIL, 1988), além de determinar ao Poder Público a obrigatoriedade de promover a EA. Esse dispositivo constitucional recepcionou2 a Lei no 6.938/81, a qual já enunciava o "art. $2^{\circ}$ - [...] X - educação ambiental a todos os níveis de ensino, inclusive a educação da comunidade, objetivando capacitá-la para participação ativa na defesa do meio ambiente" (BRASIL, 1981).

A Conferência das Nações Unidas sobre Meio Ambiente (CNUMAD), a ECO-92, que ocorreu em junho de 1992 no Rio de Janeiro, contou com representantes de 179 países e reafirmou a preocupação mundial com o meio ambiente. Paralelamente a este evento foi realizado o Fórum Global das ONGs3, elaborando-se o Tratado de Educação Ambiental para Sociedades Sustentáveis e Responsabilidade Global4 no qual se reconheceu "[...] o papel central da educação

1 Conferência Intergovernamental de Educação Ambiental de Tbilisi, promovida na Geórgia (ex-União Soviética), entre 14 e 26 de outubro de 1977, organizada pela UNESCO e o Programa de Meio Ambiente da ONU (PNUMA).

2 Recepção é o instituto pelo qual a nova Constituição, independente de qualquer previsão expressa, recebe norma infraconstitucional (lei ordinária) pertencente ao ordenamento anterior (editada antes dela), com ela compatível, dando-lhe, a partir daquele instante, nova eficácia.

3 "Organizações Não-Governamentais são organizações formadas pela sociedade civil sem fins lucrativos e que tem como missão a resolução de algum problema da sociedade, seja ele econômico, racial, ambiental, e etc, ou ainda a reivindicação de direitos e melhorias e fiscalização do poder público." (FARIA, [201-]).

4 JORNADA DE EDUCAÇÃO AMBIENTAL. Tratado de Educação Ambiental para Sociedades Sustentáveis e Responsabilidade Global. Rio de Janeiro, 1992. Disponível em: 
na formação de valores e na ação social" (JORNADA DE EDUCAÇÃO AMBIENTAL, 1992), afirmando

A educação é um direito de todos; somos todos aprendizes e educadores. A educação ambiental deve ter como base o pensamento crítico e inovador, em qualquer tempo ou lugar, em seus modos formal, não-formal e informal, promovendo a transformação e a construção da sociedade. (JORNADA DE EDUCAÇÃO AMBIENTAL, 1992).

O Conselho Nacional de Educação (CNE) aprovou em 1998 os Parâmetros Curriculares Nacionais (PCN) (BRASIL, 1998a), inserindo a preservação do meio ambiente como tema transversal nos currículos escolares por se tratar de problema social urgente e atual.

A contribuição dos PCN (1998b) para a EA é percebida na abordagem

[...] A perspectiva ambiental deve remeter os alunos à reflexão sobre os problemas que afetam a sua vida, a de sua comunidade, a de seu país e a do planeta. Para que essas informações os sensibilizem e provoquem o início de um processo de mudança de comportamento, é preciso que o aprendizado seja significativo, isto é, os alunos possam estabelecer ligações entre o que aprendem e a sua realidade cotidiana, e o que já conhecem. Nesse sentido, o ensino deve ser organizado de forma a proporcionar oportunidades para que os alunos possam utilizar o conhecimento sobre Meio Ambiente para compreender a sua realidade e atuar nela, por meio do exercício da participação em diferentes instâncias: nas atividades dentro da própria escola e nos movimentos da comunidade. É essencial resgatar os vínculos individuais e coletivos com o espaço em que os alunos vivem para que se construam essas iniciativas, essa mobilização e envolvimento para solucionar problemas (BRASIL, 1998b, p. 189-190).

Ainda na esteira dos movimentos ambientalistas e ecológicos, surgiu a Política Nacional de Educação Ambiental (PNEA), com a edição da Lei oㅡ 9.795/99, oriunda do Projeto de Lei n. 3.792/1993, realçando que a melhoria da qualidade de vida e a conservação do meio ambiente possuem estreito vínculo com os processos de educação ambiental efetivos e abrangentes, apresentava como justificativa:

[...] A modificação de práticas e atitudes no sentido de uma ética sustentável, de uma nova forma de entendimento das relações humanas com a natureza, requer o estabelecimento de estratégias nacionais para motivar, para educar as pessoas em tal direção. É este o papel da Política Nacional de Educação Ambiental [...] (FELDMAN, 1993, p. 8). 
A EA passou a ser entendida como sendo "os processos por meio dos quais o indivíduo e a coletividade constroem valores sociais, conhecimentos, habilidades, atitudes e competências voltadas para a conservação do meio ambiente", prescrevendo-o, ainda, que deveria ser incrementada de "forma articulada, em todos os níveis e modalidades do processo educativo, formal e nãoformal" (BRASIL, 1999). Apresenta como princípios ínsitos no art. 4:

\footnotetext{
I - o enfoque humanista, holístico, democrático e participativo;

II - a concepção do meio ambiente em sua totalidade, considerando a interdependência entre o meio natural, o sócio-econômico e o cultural, sob o enfoque da sustentabilidade;

III - o pluralismo de idéias e concepções pedagógicas, na perspectiva da inter, multi e transdisciplinaridade;

IV - a vinculação entre a ética, a educação, o trabalho e as práticas sociais;

$\mathrm{V}$ - a garantia de continuidade e permanência do processo educativo; VI - a permanente avaliação crítica do processo educativo;

VII - a abordagem articulada das questões ambientais locais, regionais, nacionais e globais;

VIII - o reconhecimento e o respeito à pluralidade e à diversidade individual e cultural.
}

Os objetivos fundamentais da PNEA destacam o exercício da cidadania na defesa da qualidade ambiental, através de uma atuação crítica, levando-se em conta a "compreensão integrada do meio ambiente em suas múltiplas e complexas relações, envolvendo aspectos ecológicos, psicológicos, legais, políticos, sociais, econômicos, científicos, culturais e éticos [...] (BRASIL, 1999).

A regulamentação dessa lei se deu três anos após a sua aprovação, através do Decreto ํㅜ 4.281, de 25 de junho de 2002.

O Conselho Nacional de Educação (CNE), através da Resolução n 2, de 15 de junho de 2012, estabeleceu as Diretrizes Curriculares Nacionais para a Educação Ambiental (DCNEA), ressaltando que a EA deve ter uma abordagem que considere a "interface entre a natureza, a sociocultura, a produção, o trabalho, o consumo, superando a visão despolitizada, acrítica, ingênua e naturalista ainda muito presente na prática pedagógica das instituições de ensino" (MINISTÉRIO DA EDUCAÇÃO, 2012a, art. $6^{\circ}$ ). Aponta entre seus objetivos "estimular a reflexão crítica e propositiva da inserção da Educação Ambiental na formulação, execução e avaliação dos projetos institucionais e pedagógicos das instituições de ensino [...]" (MINISTÉRIO DA EDUCAÇÃO, 2012b).

Dessa forma, este estudo de caso, parte integrante de uma pesquisa mais ampla no Curso de Mestrado Profissional Interdisciplinar do Programa de PósGraduação em Planejamento e Análise de Políticas Públicas da Universidade Estadual Paulista (UNESP) de Franca, intitulado A EDUCAÇÃO AMBIENTAL NO ENSINO FUNDAMENTAL II: uma análise em três escolas públicas do município de Batatais/SP, teve como objetivo geral analisar o que tem sido realizado em termos 
de EA em uma escola pública estadual de período integral de ensino fundamental II do município de Batatais/SP.

Quanto à abordagem utilizou-se a pesquisa qualitativa que objetiva analisar o que tem sido desenvolvido em termos de EA na escola estudada, com a finalidade de conhecer a realidade vivenciada, uma vez que segundo Silveira e Córdova (2009, p. 32) "preocupa-se, portanto, com aspectos da realidade que não podem ser quantificados, centrando-se na compreensão e explicação da dinâmica das relações sociais".

Quanto aos objetivos utilizou-se a pesquisa descritiva que objetiva "descrever com exatidão os fatos e fenômenos de determinada realidade" (TRIVIÑOS, 1987, p. 100).

Quanto aos procedimentos foi realizada pesquisa documental nos arquivos da escola objetivando a consecução do plano de gestão e do projeto político-pedagógico, além de outros documentos que apontam o que tem sido desenvolvido na questão de EA e de que forma ela ocorre.

O tratamento dos dados ocorreu utilizando-se da análise de conteúdo, que segundo Zanella (2009, p. 126-127)

[...] trabalha com materiais textuais escritos, tanto textos que são resultados do processo de pesquisa como as transcrições de entrevista e os registros das observações, como textos que foram produzidos fora do ambiente de pesquisa como jornais, livros e documentos internos e externos das organizações (ZANELLA, 2009, p. 126-127).

Delimitou-se o intervalo de estudo aos anos de 2017 e 2018, sendo que o ciclo II do ensino fundamental foi escolhido pelo fato de que a faixa etária dos alunos compreendida nesta etapa - entre 10 e 14 anos de idade - é quando ocorre a transição da fase infantil para a da adolescência e o Estatuto da Criança e do Adolescente (ECA) (BRASIL, 1990) os consideram como pessoas humanas em desenvolvimento, inclusive sujeitas de direitos, conforme se observa:

$[\ldots]$

Art. 15. A criança e o adolescente têm direito à liberdade, ao respeito $\mathrm{e}$ à dignidade como pessoas humanas em processo de desenvolvimento e como sujeitos de direitos civis, humanos e sociais garantidos na Constituição e nas leis. (BRASIL, 1990, grifo nosso).

Ademais, a escola é fundamental na formação do cidadão em desenvolvimento, estimulando hábitos, atitudes e ações que possam contribuir sobremaneira para um meio ambiente mais equilibrado e sustentável. Nos dizeres de Hartung

[...] A educação é a base e o motor da mudança de verdade e só a ação política republicano-democrática e equilibrada, conduzida com 
os pés bem firmes no chão concreto da realidade e a partir de olhares lúcidos, racionais e inclusivos, pode promovê-la e incentivá-la no rumo do desenvolvimento socioeconômico sustentável e equitativo" (HARTUNG, P. 2019).

Aliás, o protagonismo juvenil pode ser constatado diuturnamente pelo mundo, podendo citar como exemplo a adolescente sueca Greta Thunberg5, com 16 anos e que há anos mobiliza os cidadãos contra as mudanças climáticas, sendo, inclusive, indicada ao Prêmio Nobel da Paz. A consciência de sua responsabilidade cidadã na relação com o meio ambiente e qualidade de vida tem sido a diferença, conforme sua afirmação - "As mudanças climáticas estão aqui, ameaçando o futuro, e os adultos responsáveis não estão levando isso a sério"6 (HARTUNG, P., 2019a).

Outro exemplo a demonstrar a relevância e a importância da difusão e prática de uma EA crítica para os jovens é o caso do adolescente Rhenan Cauê, de 13 anos de idade, autor de projeto de revitalização e recuperação de um córrego na sua cidade, contemplando limpeza das margens envolvendo um mutirão e plantio de mudas, ação que mobilizou a sociedade civil e órgãos públicos7.

Estes e outros exemplos fizeram com que se procurasse analisar o que tem sido realizado em termos de EA na Escola Estadual Silvio de Almeida, do ciclo II do ensino fundamental do município de Batatais/SP.

\section{A CONSTRUÇÃo DA POLÍTICA PÚBLICA DE EDUCAÇÃo AMBIENTAL E A ESCOLA INVESTIGADA}

Cotidianamente a crise socioambiental é abordada face a degradação do meio ambiente, que muito tem impactado a qualidade de vida e a sobrevivência da pessoa humana.

Para Tamaio (2008, p. 24) a institucionalização da EA surgiu, em um primeiro momento, com os movimentos ecológicos preocupados em mobilizar o envolvimento da sociedade em ações socioambientais e demonstrar o esgotamento dos recursos naturais e, num outro no qual a EA passa a constituir uma proposta relacionada à seara educacional, suas teorias, saberes e tradições. $O$ autor defende, ainda, que:

5 BBC BRASIL. Greta Thunberg a adolescente sueca que está sacudindo a luta ambiental. BBC NEWS BRASIL, São Paulo, 23 abr. 2019. Disponível em: https://www.bbc.com/portuguese/geral48022690. Acesso em: 22 jul. 2019.

6 Sustentabilidade: das ideias às ações transformadoras. Disponível em:

https://www1.folha.uol.com.br/opiniao/2019/05/sustentabilidade-das-ideias-as-acoes-

transformadoras.shtml. Acesso em: 22 jul. 2019.

7 Jovem de 13 anos lidera projeto para limpar afluente do rio Araguaia. Disponível em:

https://www1.folha.uol.com.br/empreendedorsocial/2019/07/jovem-de-13-anos-lidera-projeto-para-

limpar-afluente-do-araguaia.shtml. Acesso em: 22 jul. 219.

A EDUCAÇÃO AMBIENTAL PRATICADA EM UMA ESCOLA PÚBLICA DE ENSINO

FUNDAMENTTAL II DE UM MUNICÍPIO DO INTERIOR DE SÃO PAULO - pp. 9-26 
[...] a origem e a institucionalização da EA no Brasil foram diretamente influenciadas pelos resultados e desdobramentos, em âmbito interno, das grandes conferências ambientais internacionais promovidas pela ONU, as quais se traduziram em uma instância de disputa sobre os interesses hegemônicos do capitalismo na sua relação de apropriação da natureza. Elas repercutiram e fortaleceram a discussão no movimento ecológico - pela ação das entidades e organizações da sociedade civil, no Estado brasileiro -, ao organizar agências de meio ambiente que passaram a desenvolver ações e políticas centradas nas questões ambientais (TAMAIO, 2008, p. 24).

Efetivamente, os movimentos ambientalistas aliados ao quanto discutido nos eventos internacionais foram fundamentais por apontar a crise ambiental como relevante questão de interesse público.

Carvalho (2008, p. 51) preceitua que a EA é parte integrante do movimento ecológico, apontando que ela advém da preocupação da coletividade "com o futuro da vida e com a qualidade da existência das presentes e futuras gerações".

Várias são as concepções de EA e segundo Tozoni-Reis (2008, p. 49) surgem das diferentes práticas educativas ambientais, as quais apresenta como sendo:

[...] a Educação Ambiental para mudança de comportamentos considerados ambientalmente incorretos (a-crítica); a Educação Ambiental centrada na transmissão de conhecimentos técnicos e científicos sobre os processos naturais (a-crítica); e a Educação Ambiental como um processo político de apropriação crítica de conhecimentos, atitudes, valores e comportamentos para a construção, coletiva e participativa, de uma sociedade sustentável (TOZONI-REIS, 2008, p. 49).

Essa última concepção, a EA crítica, tem-se como a mais adequada para o cotidiano de enfrentamento da situação vivenciada, pois objetiva propiciar a percepção da problemática socioambiental levando-se em conta as suas várias dimensões, inclusive a PNEA objetiva o "estímulo e o fortalecimento de uma consciência crítica sobre a problemática ambiental e social [...]. Nessa ótica é que se conduziu o presente estudo.

Carvalho (2008, p. 125), referindo-se a EA Crítica, informa que ela "seria, portanto, aquela capaz de transitar entre os múltiplos saberes: científicos, populares e tradicionais, alargando nossa visão do ambiente e captando os múltiplos sentidos que os grupos sociais atribuem a ele" (CARVALHO 2008, p. 125).

Segundo Loureiro (2008, p. 69) a EA apresenta um caráter transformador e emancipatório ao preconizar que 
[...] A Educação Ambiental é uma práxis educativa e social que tem por finalidade a construção de valores, conceitos, habilidades e atitudes que possibilitem o entendimento da realidade de vida e a atuação lúcida e responsável de atores sociais individuais e coletivos no ambiente. Nesse sentido, contribui para a tentativa de implementação de um padrão civilizacional e societário distinto do vigente, pautado numa nova ética da relação sociedade-natureza" (LOUREIRO, 2008, p. 69).

\section{Acrescenta ainda referido autor que}

[...] a educação ambiental necessita vincular os processos ecológicos aos sociais na leitura de mundo, na forma de intervir na realidade e de existir na natureza. Reconhece, portanto, que nos relacionamos na natureza por mediações que são sociais, ou seja, por meio de dimensões que criamos na própria dinâmica de nossa espécie e que nos formam ao longo da vida (cultura, educação, classe social, instituições, família, gênero, etnia, nacionalidade etc). [...] Para a educação ambiental crítica, conseqüentemente, a prática escolar exige o conhecimento da posição ocupada por educandos na estrutura econômica, da dinâmica da instituição escolar e suas regras e da especificidade cultural do grupo social com o qual se trabalha" (LOUREIRO, 2007, p. 66-67).

Conclui-se, assim, que para a EA seja capaz de construir valores, mudar atitudes e comportamentos capazes de mobilizar o cidadão para uma relação cônscia com meio ambiente em que vive, necessário se faz com que se leve em conta os aspectos políticos, sociais, econômicos, científicos, tecnológicos, culturais, ecológicos e éticos.

Para Sorrentino et al (2005, p. 288-289) a EA surge como processo educativo "que conduz a um saber ambiental materializado em valores éticos e regras políticas de convívio social e de mercado, que implica a questão distributiva entre benefícios e prejuízos da apropriação e do uso da natureza" .

\subsection{Educação ambiental - Construção da política pública}

Para que se possa entender a educação ambiental como uma política pública, necessário a compreensão do que significa este termo.

Segundo Sato (2002, p. 23-24), a definição mais aceita internacionalmente sobre o que é EA foi forjada na Conferência de Tbilisi em 19778, que diz

8 Conferência Intergovernamental de Educação Ambiental de Tbilisi, promovida na Geórgia (exUnião Soviética), entre 14 e 26 de outubro de 1977, organizada pela UNESCO e o Programa de Meio Ambiente da ONU (PNUMA). 
A Educação Ambiental é um processo de reconhecimento de valores e clarificação de conceitos, objetivando o desenvolvimento das habilidades e modificando as atitudes em relação ao meio, para entender e apreciar as inter-relações entre os seres humanos, suas culturas e seus meios biofísicos. A Educação Ambiental também está relacionada com a prática das tomadas de decisões e a ética que conduzem para a melhoria da qualidade de vida (SATO, 2002, p. 2324).

A publicação do MEC denominada "Políticas de Melhoria da Qualidade de Educação: um balanço institucional" (MINISTÉRIO DA EDUCAÇÃO, 2002, p. 5) acentua que

Durante as décadas de 60 e 70 , a questão ambiental era
juridicamente fragmentada e desenvolvimentista. O poder público se
pautava no binômio desenvolvimento/progresso para preservar
alguns segmentos dos recursos naturais sem a preocupação da
conservação ambiental como um todo. [...]
Verificamos que tanto o Código Florestal (art. 42 ) 9 como a Lei de
Proteção à Fauna (art. 35) 10 obrigam a inserção de textos sobre
estes temas nos livros escolares com prévia aprovação do Conselho
Federal de Educação, sem maiores orientações de como e onde
fazer essas inserções dentro do currículo escolar" (MINISTÉRIO DA
EDUCAÇÃO, 2002, p. 5).

Os movimentos mundiais em torno das questões ambientais efetivamente refletiram no Brasil, estimulando conferências, seminários, cursos, fazendo com que se criasse legislações voltadas à temática e para a $E A$, podendose citar a criação da SEMA (BRASIL, 1973), as edições da PNMA (BRASIL, 1981), da CF (BRASIL, 1988) nos seus artigos 23, 24, 170 e 225, da PNEA (BRASIL, 1999) e das DCNEA (MINISTÉRIO DA EDUCAÇÃO, 2012a).

Referente a inserção da EA na educação básica, o Censo Escolar de 2001 realizado pelo Instituto Nacional de Estudos e Pesquisas Educacionais Anísio Teixeira (INEP) apontou que 61,2\% das escolas disseram trabalhar com a temática, enquanto que no Censo de 2004 este índice subiu para 94\%, dados estes que indicam, sob a ótica quantitativa, que no Brasil a EA está inserida na escola básica, segundo Tozoni-Reis et al (2013, p. 360-361). Estes mesmos autores constataram no estudo intitulado $O$ que fazem as escolas que dizem que fazem educação

90 art. 42 do Código Florestal (BRASIL, 1965) dizia que "dois anos depois da promulgação desta lei, nenhuma autoridade poderá permitir a adoção de livros escolares de leitura que não contenham textos de educação florestal, previamente aprovados pelo Conselho Federal de Educação ou órgão competente". Esta lei foi revogada pela Lei no 12.651, de 25 de maio de 2012.

100 art. 35 da Lei de Proteção da Fauna (BRASIL, 1967) diz que "dentro de dois anos, a partir da promulgação desta lei, nenhuma autoridade poderá permitir a adoção de livros escolares de leitura que não contenham textos sobre proteção da fauna, previamente aprovados pelo Conselho Federal de Educação ou órgão competente". 
ambiental? (TRAJBER; MENDONÇA, 2006), realizado pelo INEP, cujo objetivo era compreender de maneira qualitativa dessa inserção em escolas de ensino fundamental e médio do País, chegando a conclusão que

[...] uma das grandes dificuldades para a inserção da EA nas escolas está relacionada com a precariedade de recursos materiais, em que estão inseridos os materiais de pesquisa e estudo para 0 aprofundamento de temas ambientais e educacionais, inclusive para a formação permanente dos professores. Sem material adequado e em quantidade suficiente para realizar seus trabalhos, eles procuram fontes diversas, nem sempre com adequada qualidade acadêmica e científica, o que vem prejudicando o trabalho desenvolvido. [...]" (TOZONI-REIS ET AL, 2013, p. 360-361)

Assim, objetivando conhecer a realidade atual, resolveu-se analisar o que tem sido desenvolvido em termos de EA numa escola estadual do ciclo II do ensino fundamental do município de Batatais, interior do Estado de São Paulo.

\subsection{Escola Estadual Silvio de Almeida}

A Escola Estadual Silvio de Almeida encontra-se localizada na rua Coronel Joaquim Alves $\mathrm{n}^{\circ}$ 1438, bairro Riachuelo, no município de Batatais, que se situa na região nordeste do Estado de São Paulo, com população estimada11 em 62.508 habitantes e área territorial de $849,526 \mathrm{~km}^{2}$.

Foi criada pelo Decreto-lei no $16.870 / 47$ com o nome de Ginásio Estadual de Batatais (CARDOSO, 1999, p. 59). Pela Lei $n^{\circ} 623 / 50$ mudou para Colégio Estadual, e posteriormente a denominação para Colégio Estadual Silvio de Almeida.

Passou a Escola de Tempo Integral no ano de 2006 e em 2014 veio a integrar o Programa de Ensino Integral (PEI), instituído pela Lei Complementar $\mathrm{n}^{\circ}$ 1.191, de 28 de dezembro de 2012 (SÃO PAULO, 2012). O PEI objetiva difundir a cultura de gestão participativa e focada na melhoria da aprendizagem dos alunos, que juntamente com a formação das competências e habilidades necessárias, propicia o exercício da cidadania autônoma, solidária e competente, onde os docentes, laborando em regime de dedicação plena e integral, têm a sua disposição, condições diferenciadas para o exercício de seu mister.

A matriz curricular e a proposta pedagógica da escola somada ao regime de dedicação exclusiva dos professores propiciam o ambiente favorável ao desenvolvimento de projetos didáticos pedagógicos, interdisciplinares e

11 IBGE Instituto Brasileiro de Geografia e Estatística. Disponível em:

https://cidades.ibge.gov.br/brasil/sp/batatais/panorama. Acesso em: 05 set. 2019. 
multidisciplinares, sobretudo para as disciplinas eletivas, que por sua vez envolvem as diferentes áreas de conhecimento e pressupõe a diversificação de situações didáticas, pois visam aprofundar, enriquecer e ampliar estudos relativos aos conteúdos das áreas de conhecimento contempladas (SÃO PAULO, 2014).

O corpo docente é formado por 20 Professores e 4 Coordenadores, enquanto o corpo discente, no ano letivo de 2018, apresentava no ensino fundamental II o quadro total de 214 alunos.

\title{
2.2.1 Plano Gestor e projeto político-pedagógico
}

Segundo o Plano Gestor da Escola Estadual Silvio de Almeida, o seu Projeto Político-Pedagógico tem como alicerce uma concepção educativa em que o aluno, "como protagonista e construtor de saberes", é motivado a participar ativamente de seu processo de aprendizagem e a interagir com a coletividade. Prescreve que o currículo se apresenta de forma flexível e dinâmico permitindo que a ação educativa perpasse a sala de aula - "Favorece a integração entre a investigação, a vivência de novas experiências de inserção sociocultural, o conhecimento historicamente produzido e a intervenção social" (EE SILVIO DE ALMEIDA, 2015, p. 15).

Segundo as Diretrizes do Programa de Ensino Integral (SÃO PAULO, 2014, p. 28):

\begin{abstract}
"as disciplinas eletivas são um dos componentes da Parte Diversificada e, devem promover o enriquecimento, a ampliação e a diversificação de conteúdos, temas ou áreas do Núcleo Comum. Consideram a interdisciplinaridade enquanto eixo metodológico para buscar a relação entre os temas explorados, respeitando as especificidades das distintas áreas de conhecimento" (SÃO PAULO, 2014, p. 28).
\end{abstract}

Observou-se que as disciplinas eletivas são organizadas semestralmente por dois professores de disciplinas distintas, com tema de livre escolha, desde que se trate de um assunto relevante e que seja abordado de modo a aprofundar os conteúdos da Base Nacional Curricular Comum (BNCC) (MINISTÉRIO DA EDUCAÇÃO, 2016).

No tocante a EA constatou-se dos assentamentos existentes na escola, quais sejam, dos projetos e seus relatórios com síntese dos dados obtidos, que partiu de alguns alunos a proposta de uma eletiva para o segundo semestre de 2017, denominada de Cultivando Sonhos, ideia difundida entre o corpo docente e discente do $6^{\circ}$ e $7^{\circ}$ anos, projeto esse que envolveu as áreas de conhecimento/disciplina de Ciências, Matemática e Artes, alcançando os resultados esperados. Com a estruturação e implementação de horta, os alunos interviram na 
sua cultura alimentar e nutricional, incorporando uma alimentação baseada em produtos naturais, saudáveis e economicamente sustentáveis.

No primeiro semestre de 2018 os alunos do $8^{\circ}$ e $9^{\circ}$ anos desenvolveram o projeto da eletiva Corpo Sustentável - Água Fonte de Vida, objetivando dar continuidade a horta, ampliando-o e construindo Mandallas12, produzindo legumes e hortaliças para integrar a refeição na escola.

O projeto denominado Bacia Hidrográfica e Observatório Multidisciplinar, instituído objetivando discutir a realidade ambiental do município de Batatais, com a participação dos alunos dos $8^{\circ}$ e $9^{\circ}$ anos, parte do conceito de bacia hidrográfica e incorpora outras questões ambientais, tais como a importância da agroecologia e da alimentação saudável, qualidade dos recursos hídricos, sensibilização ambiental e dinâmica sociocultural e está sendo desenvolvido em parceria com a Universidade Federal de São Carlos (UFSCar), especificamente o grupo de estudos Sustenta do Programa de Pós-Graduação em Ciências Ambientais. Referido projeto foi intitulado no curso de extensão como Percepção Ambiental em Bacias Hidrográficas (PERCEBaH 1): ensino, conteúdos e práticas no ambiente escolar da Escola Estadual Silvio de Almeida - Batatais/SP, visando a sensibilização ambiental e a conservação e gestão da água, tendo "[...] como meta estudar, identificar e preparar materiais instrutivos com propostas de atividades mais eficazes para as abordagens de ensino das questões relacionadas ao meio ambiente, gestão e conservação de bacias hidrográficas"13.

Os recursos necessários para execução deste projeto vieram do Fundo Ambiental de Batatais (FAB), através da direção da escola que apresentou ao COMDEMA (BATATAIS, 2014) o plano de ação chamado Desenvolvendo a Consciência Ambiental (EE SILVIO DE ALMEIDA, 2017). Ressalte-se que trabalhar o conceito de bacia hidrográfica, como é o caso, é muito importante, pois faz com que se possa "aproveitar desde aspectos geográficos, históricos, ambientais e sociais. Acreditamos que por ser um conceito holístico permite um leque de oportunidades de aprendizagem" afirma Figueiredo (2013, p. 58). Ainda segundo a autora,

[...] é possível corroborar a ideia de Ab'Saber (1987) quando diz que o estudo da bacia hidrográfica possibilita uma visão sistêmica e integrada do ambiente, sobretudo devido à clara delimitação da mesma e à natural interdependência dos processos climatológicos, hidrológicos e geológicos que nela ocorrem, considerando, ainda, que sobre esses subsistemas atuam as forças antropogênicas e que

12 Mandalla é um sistema de produção de culturas em círculos concêntricos, cujas estruturas internas são chamadas de anéis, em torno de uma única fonte de água para irrigação, distribuída de maneira uniforme e que permite melhor aproveitamento da água e do solo.

13 Percepção Ambiental em Bacias Hidrográficas (PERCEBaH 1): ensino, conteúdos e práticas no ambiente escolar da Escola Estadual Silvio de Almeida - Batatais/SP. Disponível em:

http://www.extensao.ufscar.br/site/menu_projetos/Meio_Ambiente. Acesso em: 17 jul. 2019. 
neles as atividades e os sistemas econômicos, sociais e biogeofísicos interagem" (FIGUEIREDO, 2013, p. 57).

Constata-se que o estudo da bacia hidrográfica do município permite aos alunos utilizarem-se, de forma interdisciplinar, o conteúdo aprendido em várias disciplinas, propiciando uma visão sistêmica e integrada do meio ambiente. Também permite a constatação de como a ação humana pode impactar o equilíbrio do meio ambiente e promover nos alunos a consciência da importância da mudança de atitudes e comportamentos na sua relação com aquele.

Corroborando tal entendimento ODUM (1971, p. 39 apud FIGUEIREDO, 2013, p. 57), assinala que

O conceito de Bacia Hidrográfica ajuda a colocar em perspectiva muito dos nossos problemas e conflitos. Por exemplo, as causas e as soluções da poluição da água não serão encontradas olhando-se apenas para a água; geralmente, pelo gerenciamento incorreto da bacia hidrográfica que destrói nossos recursos aquáticos [...] (ODUM, 1971, p. 39 apud FIGUEIREDO, 2013, p. 57).

As fases do projeto Bacia Hidrográfica e Observatório Multidisciplinar envolvem a formação continuada dos professores no tocante a questão ambiental, que inclui ainda a elaboração de material didático com a participação dos docentes através de oficinas, visando a adequação e a complementação dos conteúdos programáticos das disciplinas obrigatórias ministradas, para aplicação às especificidades locais e a realidade regional de abordagem dos temas ambientais na gestão de bacias hidrográficas.

\section{CONSIDERAÇÕES FINAIS}

As ações práticas desenvolvidas na escola objeto deste estudo através de projetos têm envolvido toda a comunidade escolar no que refere a questão ambiental, o que permite uma formação crítica e transformadora dos alunos em relação com o Meio Ambiente.

Destaca-se entre os projetos o denominado Bacia Hidrográfica e Observatório Multidisciplinar, exemplo de espaço pedagógico multidisciplinar onde os alunos colocam em prática os conhecimentos teóricos, desenvolvendo atitudes e habilidades que os capacitam para sua atuação, prevenção, identificação e solução de problemas ambientais locais.

O projeto contempla ainda a formação continuada dos professores na questão ambiental, inclui a elaboração de material didático com a participação destes, através de oficinas, visando a adequação e a complementação dos conteúdos programáticos das disciplinas obrigatórias ministradas, para aplicação às 
especificidades locais e a realidade regional de abordagem dos temas ambientais na gestão de bacias hidrográficas.

Concilia os conteúdos da Base Nacional Curricular Comum com a Parte Diversificada abordando as questões ambientais, de forma inter e multidisciplinar, objetivando a formação dos cidadãos em desenvolvimento, cônscios de seus direitos e deveres em relação a coletividade e com ambiente a sua volta, e na sua sensibilização como ator dentro deste contexto, moldando seus valores de maneira a contribuir com o meio ambiente ecologicamente equilibrado. A atividade prática desenvolvida pelos alunos na forma contextualizada e planejada observada no projeto incentiva-os a conhecer a situação socioambiental vivenciada no seu ambiente e a resolverem os problemas.

O fato de a escola trabalhar com projetos voltados à educação ambiental reunindo a comunidade escolar e abordando a realidade local impactam os alunos tanto individual como coletivamente, pois disseminam no seu meio social e familiar as experiências vivenciadas, tornando-os verdadeiros agentes multiplicadores.

Para que a EA possa contribuir para uma mudança de valores e incutir no cidadão a consciência de sua responsabilidade com o meio ambiente em que está inserido e delinear ações voltadas a preservá-lo, não basta que a escola trabalhe só a teoria, conceitos e informações de perspectiva conservadora, mas sim que a questão seja enfrentada em ações práticas, de forma transversal e transdisciplinar para que realmente adquira além de habilidades e competências, o aprendizado necessário para atuar criticamente, como verificado na escola estudada.

\section{REFERÊNCIAS}

BATATAIS. Lei n. 3.267, de 18 de março de 2014. Dispõe sobre a alteração da Lei 1.185, de 14 de abril de 1980, que cria o Conselho Municipal de Defesa do Meio Ambiente COMDEMA. Disponível em: http://www.camarabatatais.sp.gov.br/wpcontent/uploads/leis/lei3267.pdf. Acesso em: 12 dez. 2018.

BBC BRASIL. Greta Thunberg a adolescente sueca que está sacudindo a luta ambiental. BBC NEWS BRASIL, São Paulo, 23 abr. 2019. Disponível em: https://www.bbc.com/portuguese/geral-48022690. Acesso em: 22 jul. 2019.

BRASIL. Decreto n. 73.030, de 30 de outubro de 1973, que cria, no âmbito do Ministério do Interior, a Secretaria Especial do Meio Ambiente - SEMA, e dá outras providências. Diário Oficial da União, Brasília, DF, 30 out. 1973. Disponível em: http://www2.camara.leg.br/legin/fed/decret/1970-1979/decreto-73030-30-outubro-1973421650-publicacaooriginal-1-pe.html. Acesso em: 15 maio 2018.

BRASIL. Lei n. 6.938, de 31 de agosto de 1981. Dispõe sobre a Política Nacional do Meio Ambiente, seus fins e mecanismos de formulação e aplicação, e dá outras providências. 
Diário Oficial da União, Brasília, DF, 2 set. 1981. Disponível em:

http://www.planalto.gov.br/ccivil_03/leis/L6938.htm. Acesso em: 22 out. 2016.

BRASIL. Constituição da República Federativa do Brasil de 1988. Diário Oficial da União, Brasília, DF, 5 out. 1988. Disponível em: http://www.planalto.gov.br/ccivil _03/constituicao/constituição.htm. Acesso em: 13 maio 2017.

BRASIL. Lei n. 8.069, de 13 de julho de 1990. Dispõe sobre o Estatuto da Criança e do Adolescente e dá outras providências. Diário Oficial da União, Brasília, DF, 16 jul. 1990b. Disponível em: http://www.planalto.gov.br/ccivil_03/leis//8069.htm. Acesso em: 20 abr. 2019.

BRASIL. Secretaria de Educação Fundamental. Parâmetros Curriculares Nacionais: terceiro e quarto ciclos do ensino fundamental: apresentação dos temas transversais. Brasília, DF: MEC/SEF, 1998a. v. 10.1. Disponível em:

http://portal.mec.gov.br/seb/arquivos/pdf/ttransversais.pdf. Acesso em: 20 jan. 2019.

BRASIL. Secretaria de Educação Fundamental. Parâmetros Curriculares Nacionais: terceiro e quarto ciclos do ensino fundamental: meio ambiente. Brasília, DF: MEC/SEF, 1998b. v. 10.3. Disponível em: http://portal.mec.gov.br/seb/arquivos/ pdf/meioambiente.pdf. Acesso em: 20 jan. 2019.

BRASIL. Lei n. 9.795, de 27 de abril de 1999. Dispõe sobre a educação ambiental, institui a Política Nacional de Educação Ambiental e dá outras providências. Diário Oficial da União, Brasília, DF, 28 abr. 1999. Disponível em:

http://www.planalto.gov.br/ccivil_03/leis/L9795.htm. Acesso em: 1 mar 2017.

BRASIL. Decreto n. 4.281, de 25 de junho de 2002. Regulamenta a Lei no 9.795, de 27 de abril de 1999, que institui a Política Nacional de Educação Ambiental, e dá outras providências. Diário Oficial da União, Brasília, DF, 26 jun. 2002. Disponível em: http://www.planalto.gov.br/ccivil_03/decreto/2002/d4281.htm. Acesso em: 10 jun. 2018.

CARDOSO, C. S. C. M. (org.). IESA de ouro. Batatais: S.C.P., 1999.

CARVALHO, I. C. M. Educação ambiental: a formação do sujeito ecológico. 4. ed. São Paulo: Cortez, 2008.

DIAS, G. F. Os quinze anos da educação ambiental no Brasil: um depoimento. Em Aberto, Brasília, DF, v. 10, n. 49, jan./mar. 1991. Disponível em: http://emaberto.inep.gov.br/index.php/emaberto/article/view/1798/1769. Acesso em: 15 jan. 2019.

DIAS, G. F. Educação ambiental: princípios e práticas. 9. ed. São Paulo: Gaia, 2004.

EE "SILVIO DE ALMEIDA". Plano de Gestão 2015 - 2018. Batatais, 2015.

EE "SILVIO DE ALMEIDA". Apresentação de proposta para uso de verba do FAB - Fundo Ambiental de Batatais - Projeto Desenvolvendo a Consciência Ambiental. Batatais, 2017. 
FARIA, C. ONGs (Organizações não Governamentais). [São Paulo], [201-]. Disponível em: https://www.infoescola.com/geografia/ongs-organizacoes-nao-governamentais/. Acesso em: 10 jun. 2018.

FELDMAN, F. Projeto de lei n. 3.792, de 6 de maio de 1993. Dispõe sobre a educação ambiental, institui a Politica Nacional de Educação Ambiental e da outras providências. Diário do Congresso Nacional, Brasília, DF, ano 18, n. 95, 4 jun. 1993. Disponível em: http://www.camara.gov.br/proposicoesWeb/ fichadetramitacao?idProposicao=215990. Acesso em: 10 jun. 2018.

FIGUEIREDO, A. N. Análise reflexiva da produção participativa e da dimensão crítica de materiais de educação ambiental no contexto de bacias hidrográficas no estado de São Paulo. 2013. 118 f. Dissertação (Mestrado em Ecologia e Recursos Naturais) - Universidade Federal de São Carlos, São Carlos, 2013.

HARTUNG, P. Sustentabilidade: das ideias às ações transformadoras. Folha de S. Paulo, São Paulo, 21 maio 2019. Opinião. Disponível

em: https://www1.folha.uol.com.br/opiniao/2019/05/sustentabilidade-das-ideias-as-acoestransformadoras.shtml. Acesso em: 22 jul. 2019.

HARTUNG, P. Educação como motor de uma nova história. O Estado de São Paulo, São Paulo, 03 set. 2019. Opinião. Disponível em: https://digital.estadao.com.br/o-estado-de-spaulo/20190903. Acesso em: 03 set. 2019.

IBGE. Cidades e Estados: Brasil em síntese: Batatais. Rio de Janeiro, 2017. Disponível em: https://cidades.ibge.gov.br/brasil/sp/batatais/. Acesso em: 21 mar. 2018.

INEP. Índice de Desenvolvimento da Educação Básica. Brasília, DF, 2018. Disponível em: idebescola.inep.gov.br/ideb/escola. Acesso em: 13 nov. 2018.

JORNADA DE EDUCAÇÃO AMBIENTAL. Tratado de Educação Ambiental para Sociedades Sustentáveis e Responsabilidade Global. Rio de Janeiro, 1992. Disponível em: https://www.mma.gov.br/informma/item/8068-tratado-de-educa\%C3\%A7\%C3\%A3oambiental-para-sociedades-sustent\%C3\%A1veis-e-responsabilidade-global.html. Acesso em: 10 jul. 2019.

LOUREIRO, C. F. B. Educação Ambiental crítica: contribuições e desafios. In: Vamos cuidar do Brasil: conceitos e práticas em educação ambiental na escola. Coordenação: Soraia Silva de Mello, Rachel Trajber. Brasília, DF: Ministério da Educação: Coordenação Geral de Educação Ambiental: Ministério do Meio Ambiente, Departamento de Educação Ambiental: UNESCO, 2007.

LOUREIRO, C. F. B. Educação ambiental e movimentos sociais na construção da cidadania ecológica e planetária. In: LOUREIRO, C. F. B.; LAYRARGUES, P. P.; CASTRO, R. S. (org.). Educação ambiental: repensando o espaço da cidadania. 4. ed. São Paulo: Cortez, 2008. 
MINISTÉRIO DA EDUCAÇÃO. Secretaria de Educação Fundamental. Políticas de melhoria da qualidade da educação: um balanço Institucional - 2002. Disponível em:

http://www.dominiopublico.gov.br/download/texto/me4568.pdf. Acesso em: 15 maio 2018.

MINISTÉRIO DA EDUCAÇÃO. Conselho Nacional de Educação. Parecer CNE/ CP n. 14, de 6 de junho de 2012. Diretrizes Curriculares Nacionais para a Educação Ambiental. Diário Oficial da União, Brasília, DF, 15 jun. 2012a. Disponível em:

http://portal.mec.gov.br/docman/maio-2012-pdf/10955-pcp014-12. Acesso em: 31 mar. 2019.

MINISTÉRIO DA EDUCAÇÃO. Conselho Nacional de Educação. Conselho Pleno.

Resolução n. 2, de 12 de junho de 2012. Estabelece as Diretrizes Curriculares Nacionais para a Educação Ambiental. Diário Oficial da União, Brasília, DF, 18 jun. 2012b. Disponível em: http://portal.mec.gov.br/index.php?option=com_docman\&view=download\&alias=10988rcp002-12-pdf\&category_slug=maio-2012-pdf\&ltemid=30192. Acesso em: 23 fev. 2019.

MINISTÉRIO DA EDUCAÇÃO. Base Nacional Curricular Comum: 2 $2^{\underline{a}}$ versão revista. Brasília, DF, abr. 2016. Disponível em: http://historiadabncc.mec.gov.br/ documentos/bncc-

2versao.revista.pdf. Acesso em: 11 maio 2018.

ONU. Declaração de Estocolmo sobre o Meio Ambiente Humano - 1972. Estocolmo, jun. 1972. Disponível em: http://www.direitoshumanos.usp.br/index.php/Meio-

Ambiente/declaracao-de-estocolmo-sobre-o-ambiente-humano.html. Acesso em: 10 jun. 2018.

PAMPLONA, P. Jovem de 13 anos lidera projeto para limpar afluente do Araguaia. Folha de S. Paulo, São Paulo, 21 maio 2019. Opinião. Disponível em: https://www1 .folha.uol.com.br/empreendedorsocial/2019/07/jovem-de-13-anos-lideraprojeto-para-limpar-afluente-do-araguaia.shtml. Acesso em: 22 jul. 2019.

SÃO PAULO (Estado). Decreto-Lei n. 16.870, de 10 de fevereiro de 1947. Dispõe sobre criação de um Ginásio Estadual, em Batatais. Diário Oficial do Estado de São Paulo, São Paulo, ano 57, n. 33, 11 fev. 1947. Disponível em:

https://www.al.sp.gov.br/repositorio/legislacao/decreto.lei/1947/decreto.lei-1687010.02.1947.html. Acesso em: 25 mar. 2018.

SÃO PAULO (Estado). Lei n. 623, de 04 de janeiro de 1950. Dispõe sobre a criação de colégios estaduais nas cidades de Assis, Batatais e Capivari. Diário Oficial do Estado de São Paulo, São Paulo, ano 60, n. 4, 5 jan. 1950. Disponível em:

https://www.imprensaoficial.com.br/DO/BuscaDO2001Documento_11_4.aspx?link=/1950/ex ecutivo/janeiro/05/pag_0002_524DP68J0JBNPe1BUSA0SRUFHOI.pdf\&pagina=2\&data=05/ 01/1950\&caderno=Executivo\&paginaordenacao=100002. Acesso em: 13 nov. 2018.

SÃO PAULO (Estado). Lei Complementar n. 1.191, de 28 de dezembro de 2012. Dispõe sobre o Programa Ensino Integral em escolas públicas estaduais e altera a Lei Complementar no 1.164, de 2012, que instituiu o Regime de Dedicação Plena e Integral RDPI e a Gratificação de Dedicação Plena e Integral - GDPI aos integrantes do quadro do 
magistério em exercício nas escolas estaduais de ensino médio de período integral, e dá providências correlatas. Diário Oficial do Estado de São Paulo, São Paulo, v. 122, n. 243, 29 dez. 2012b. Disponível em:

https://www.al.sp.gov.br/repositorio/legislacao/lei.complementar/2012/lei.complementar1191-28.12.2012.html. Acesso em: 10 maio 2018.

SÃO PAULO (Estado). Diretrizes do Programa de Ensino Integral: escola de tempo integral. São Paulo, [2014]. Disponível em: http://www.educacao.sp.gov.br/ a2sitebox/arquivos/documentos/726.pdf. Acesso em: 10 maio 2018.

SATO, M. Educação ambiental. São Carlos: RiMa, 2002.

SILVEIRA, D. T.; CÓRDOVA, F. P. A pesquisa científica. In: GERHARDT, T. E.; SILVEIRA, D. T. (org.). Métodos de pesquisa. Porto Alegre: UFRGS, 2009.

SORRENTINO, M. et al. Educação ambiental como política pública. Educação e Pesquisa, São Paulo, v. 31, n. 2, p. 285-299, maio/ago. 2005. Disponível em: http://www.scielo.br/pdf/ep/v31n2/a10v31n2.pdf. Acesso em: 6 jun. 2017.

TAMAIO, I. A política pública de educação ambiental. Salto para o Futuro: Educação Ambiental no Brasil, Brasília, DF, ano 18, n. 1, p. 21-29, mar. 2008. Disponível em: http://forumeja.org.br/sites/forumeja.org.br/files/Educa\%C3\%A7\%C3\%A30\%20Ambiental\%2 0no\%20Brasil\%20(texto\%20basico).pdf. Acesso em: 28 maio 2018.

TOZONI-REIS, M. F. C. A inserção da educação ambiental na escola. Salto para o Futuro: Educação Ambiental no Brasil, Brasília, DF, ano 18, n. 1, p. 46-53, mar. 2008. Disponível em:

http://forumeja.org.br/sites/forumeja.org.br/files/Educa\%C3\%A7\%C3\%A3०\%20Ambiental\%2 0no\%20Brasil\%20(texto\%20basico).pdf. Acesso em: 28 maio 2018.

TOZONI-REIS, M. F. C. et al. A inserção da educação ambiental na educação básica: que fontes de informação os professores utilizam para sua formação? Ciência \& Educação, Bauru, v. 19, n. 2, p. 359-377, 2013. Disponível em: http://www.scielo.br/scielo.php?pid=S1516-73132013000200009\&script=sci_abstract\&tlng=. Acesso em: 20 out. 2016.

TRAJBER, R.; MENDONÇA, P. R. (org.). Educação na diversidade: o que fazem as escolas que dizem que fazem educação ambiental? Brasília, DF: Secretaria de Educação Continuada, Alfabetização e Diversidade, 2006.

TRIVIÑOS, A. N. S. Introdução à pesquisa em ciências sociais: a pesquisa qualitativa em educação. São Paulo: Atlas, 1987.

ZANELLA, L. C. H. Metodologia de estudo e de pesquisa em administração. Florianópolis: UFSC; [Brasília, DF]: CAPES: UAB, 2009. 


\section{A EDUCAÇÃO INFANTIL NO BRASIL: A trajetória de conquistas e desafios}

DONIZETTE, Lidiane Cristina

Mestranda - UNESP/Franca

lidichrist@gmail.com

ANDRADE, Lucimary Bernabé Pedrosa de Doutora em Serviço Social - UNESP/Franca. lucimarypandrade@yahoo.com.br

\section{INTRODUÇÃO}

Ao percorrermos a história da educação infantil no Brasil verifica-se que nem sempre a criança foi protegida por leis que garantisse seu direito à educação e muito menos ao acesso a instituições de educação infantil.

A história revela que a educação das crianças esteve muito tempo sob a responsabilidade exclusiva da família, visto que era através do convívio com os adultos e outras crianças que elas participavam das tradições e aprendia a regras de convívio de sua cultura.

O presente artigo tem a finalidade conhecer a trajetória histórica e o quadro legal que rege a educação infantil no Brasil, bem como os avanços e os desafios para uma educação infantil de qualidade, procurando delinear a trajetória de sua história e as legislações que contribuíram com diretrizes e parâmetros educacionais para alavancar essa etapa da educação como direito das crianças de 0 a 5 anos de idade.

Este estudo se justifica, pois apesar dos grandes avanços proporcionados atualmente por diferentes leis, estudos diversos demonstram que a realidade denuncia um descompasso entre essas leis e o cotidiano das instituições de atendimento dessa etapa da educação.

Para realização deste estudo foi realizado um levantamento bibliográfico em livros e artigos científicos de autores que estudam a educação infantil no país, buscando desvendar aspectos históricos, legais e pedagógicos da educação das crianças e os desafios para a implantação de políticas públicas que assegurem uma educação infantil de qualidade.

1.1 Contextualizando a educação infantil no mundo e no Brasil 
Na Europa, a partir da Revolução Industrial surge a passagem do feudalismo para o capitalismo, em que fábricas começam a substituir o trabalho manual por maquinários. A partir de então, a sociedade começa a se reestruturar possibilitando a entrada da mulher no mercado de trabalho e, consequentemente, a alteração da estrutura social modificando os hábitos e costumes das famílias.

De acordo com Rizzo (2003) as mães operárias que não tinham com quem deixar seus filhos optavam em utilizar o trabalho de mães que optavam pelo não trabalho em fábricas e vendiam seus serviços para cuidarem dos filhos de outras mulheres. Essas enfatizavam atividades de bons hábitos de comportamento e internalização de regras morais.

\begin{abstract}
Criou-se uma nova oferta de emprego para as mulheres, mas aumentaram os riscos de maus tratos às crianças, reunidas em maior número, aos cuidados de uma única, pobre e despreparada mulher. Tudo isso, aliado a pouca comida e higiene, gerou um quadro caótico de confusão, que terminou no aumento de castigos e muita pancadaria, a fim de tornar as crianças mais sossegadas e passivas. Mais violência e mortalidade infantil. (RIZZO, 2003, p. 31).
\end{abstract}

De acordo com a autora, a preocupação das famílias era diminuir a pobreza a procura da sobrevivência, e dessa forma os maus tratos com as crianças tornaram se normais à sociedade. Dessa forma, surgem através de filantropia algumas pessoas que começaram a acolher essas crianças que se encontravam nas ruas. De acordo com Paschoal (2009, p. 80) "a sociedade aplaudiu, uma vez que todos queriam ver as ruas limpas do estorvo e da sujeira provocados pelas crianças abandonadas".

Aos poucos foram surgindo na Europa e Estados Unidos instituições com o objetivo de proteger as crianças enquanto as mães saíam de casa para trabalhar. No ocidente, essas entidades tinham objetivo assistencialista enfocando higiene, alimentação e cuidados com essas crianças. Kuhlmann Jr. (2001) mostra que essas instituições se preocupavam também com a educação já que desde o início tinham cunho pedagógico. Algumas entidades trabalhavam lições que abordavam exercícios de dança e canta oral e os materiais didáticos possibilitavam à criança o desenvolvimento do raciocínio. Segundo o autor essas instituições tinham o propósito de tirar essas crianças das ruas, mas também desenvolver a sua inteligência e os bons costumes

Ao estudarmos um pouco da história das instituições que atendem essas crianças como detentoras de direitos, encontraremos instituições criadas para cuidar, escolarizar e para receber as crianças.

Diferentes idéias, diferentes modelos de organização dos lugares e diferentes opiniões sobre o que fazer com as crianças enquanto permanecessem nessas instituições marcam a origem desses lugares. (BRASIL, 2005, p. 18).

A partir da segunda metade do século XIX o atendimento a essas crianças era realizado em creches e pré-escolas. Em nosso país essas entidades 
criaram força somente a partir da história da República. Antes disso havia a predominância de ações de caridade para crianças desamparada.

A partir de então espalhou se a ideia de que a assistência poderia resolver problemas ligados à pobreza o que reforçou um maior preconceito contra as crianças vindas de famílias pobres.

Isso acontecia à medida que os homens que falavam em nome da ciência divulgavam a idéia de que os pobres, se não fossem disciplinados e amparados, fatalmente entrariam no mundo do crime ou da vadiagem (BRASIL, 2005, p. 21).

Somente a partir de 1880 houve a necessidade de jardins de infância a serem ofertados pelo Estado. Kuhlmann Jr. (1998) relata que a primeira creche surgiu ao lado de uma fábrica de tecidos chamada Corcovado, no Rio de Janeiro. Também foi criado neste ano o Instituto de Proteção a Infância do Rio de Janeiro na qual se iniciou uma rede de assistência que se espalhou pelo país e tinha como objetivo atender as mães grávidas pobres e dar assistência aos recém-nascidos, distribuir leites, consultar as lactantes e também vacinar os bebês.

Outra instituição importante criada foi o Instituto de Proteção e Assistência à Infância que tinha o objetivo não só de fiscalizar como combater o trabalho das mães voluntárias que cuidavam de maneira precária dos filhos das trabalhadoras (KUHLMANN JR, 1998).

A partir de 1923 a presença feminina começa a ser marcante no trabalho industrial e desde então as indústrias foram pressionadas a reconhecer o direito da mulher de amamentar e o direito às crianças de um atendimento enquanto suas mães estavam no trabalho. Foram reivindicadas melhores condições de trabalho e criação de instituições de educação e cuidado com filhos das trabalhadoras.

O fato dos filhos das operárias estarem em creches, escolas maternais e jardins de infância, montadas pelas fábricas, passou a ser reconhecido por alguns empresários como vantajoso, pois mais satisfeitas, as mães operárias produziam melhor. (OLIVEIRA, 1992, p. 18).

Ao longo das décadas as conquistas em relação à educação das crianças foram ocorrendo em resposta aos avanços da industrialização e a inserção da mulher no mercado de trabalho. As mulheres por meio do movimento feminista tiveram papel importante na mudança de atendimento de crianças em creches e préescolas, defendendo a ideia de que as mesmas deveriam atender todas as mulheres independentes de suas condições sociais. Como resultado houve o aumento do número de instituições mantidas pelo poder público.

Kramer (1995, p. 24) ressalta que "o discurso do poder público, em defesa do atendimento das crianças das classes menos favorecidas, parte de 
determinada concepção de infância, já que o mesmo reconhece esse período da vida da criança de maneira padronizada e homogênea".

Surgem então diferentes propostas no sentido compensatório. Segundo Kramer (1995) a pré-escola seria uma forma de mudança social já que possibilitaria a democratização das oportunidades educacionais.

Nessa época as escolas maternais recebiam crianças de 2 a 4 anos de idade e o jardim de infância de 4 a 5 anos. E esses maternais que recebiam crianças com menos de 2 anos de idade foram chamados de berçários. Nesse sentido vê se que a sociedade começa a reconhecer esse período como infância e suas respectivas etapas relacionadas ao tempo de ser criança.

Duas décadas depois de debates e disputas políticas o Congresso Nacional criou a lei no 4024 de 20 de dezembro de 1961 que apresentou reformas na educação do país, na qual apresenta que crianças de 0 a 6 anos são possuidoras de direitos a serem atendidas em maternais e jardins de infância.

Porém, em 1971 surge uma nova lei o 5692 de agosto desse mesmo ano em que retira do governo qualquer obrigação escolar a ser oferecida às crianças de menor idade.

Os sistemas de ensino velarão para que as crianças de idade inferior a sete anos recebam conveniente educação em escolas maternais, jardins de infância e instituições equivalentes. (BRASIL, 1971).

Surge em contrapartida para essa faixa etária o Projeto Casulo, a qual tinha o propósito de espalhar redes de atendimentos baseado em trabalhos voluntários com o propósito assistencialista pregando a prevenção dos problemas sociais com ações destinadas a cuidar ou dar alimentação para resolver problemas e amparar as mães e as crianças.

No entanto, esse tipo de ação preventiva ganhou força e os jardins de infância mantidos pelo governo começaram a ter a ideia de que essas instituições deveriam custar pouco, e oferecer o mínimo para não estourar o orçamento governamental.

Assim anos depois de muitas lutas sociais é promulgada em 1988 a Constituição Federal a qual irá reconhecer a educação infantil como direito da criança de 0 a 5 anos e a garantia do atendimento em creches e pré-escolas. $O$ inciso IV diz que "O dever do Estado para com a educação será efetivado mediante a garantia de oferta de creches e pré-escolas às crianças de zero a cinco anos de idade" (BRASIL, 1988). A partir dessa lei as creches, que anteriormente eram ligadas à assistência social passam a ser responsabilidade da educação.

Dois anos após a aprovação da Constituição Federal de 1988 é sancionado o Estatuto da Criança e do Adolescente (ECA), Lei 8069/90, que reitera em seu artigo 54 que o Estado tem o dever de oferecer atendimento em creches e pré-escolas às crianças de 0 a 5 anos e em seu artigo $3^{\circ}$, a criança e o adolescente devem ter assegurados os direitos fundamentais inerentes à pessoa humana, para 
que seja possível, desse modo, ter acesso às oportunidades de "[...] desenvolvimento físico, mental, moral, espiritual e social, em condições de liberdade e dignidade" (BRASIL, 1994a). O ECA instituiu um sistema de elaboração de políticas públicas voltadas às crianças tentado impedir desvios em seus direitos.

Anos seguintes há a publicação da Lei de Diretrizes e Bases da Educação Nacional, Lei 9394/96, a qual declara que a educação infantil deverá ser ofertada em creches às crianças de 0 a 3 anos e em pré-escolas crianças de 3 a 5 anos e 11 meses, tornando a educação infantil parte integrante da educação básica no Brasil. Essa Lei define que a finalidade da educação infantil é promover o desenvolvimento integral da criança até cinco anos de idade, complementando a ação da família e da comunidade (BRASIL, 1996).

Como ressaltado no início verifica se um grande avanço a partir do proposto, já que a educação infantil embora não obrigatória é considerada em leis um direito da criança com o objetivo de proporcionar condições adequadas para seu desenvolvimento físico, motor, emocional, social, intelectual e a ampliação de suas experiências.

Anos depois o Ministério da Educação publica alguns documentos a fim de delinear uma política para educação infantil no país com quadro legal que estabelecem as diretrizes pedagógicas e recursos humanos com o objetivo de expandir a oferta de vagas e promover a melhoria da qualidade de atendimento nessa etapa.

No quadro dos documentos do MEC, em 1998 foram elaborados os Referenciais Curriculares Nacionais para a Educação Infantil (1998) a fim de contribuir para a implantação de práticas educativas de maior qualidade na educação infantil. Esse foi visto como um guia sobre os objetivos, conteúdos e orientações didáticas para os profissionais que atuam nessa etapa da educação.

O Referencial sugere que as atividades sejam oferecidas por meio de brincadeiras integrando situações de cuidar e educar.

\begin{abstract}
Educar significa, portanto, propiciar situações de cuidados, brincadeiras e aprendizagens orientadas de forma integrada e que possam contribuir para o desenvolvimento das capacidades infantis de relação interpessoal, de ser e estar com os outros, em uma atitude de aceitação, respeito e confiança, e o acesso pelas crianças, aos conhecimentos mais amplos da realidade social e cultural (BRASIL, 1998a, p. 23).
\end{abstract}

Já o cuidar deve ser visto como parte integrante da educação demandando a integração de vários campos de conhecimento. De acordo com o Referencial Curricular Nacional para Educação Infantil (1998, p. 24) "A base do cuidado humano é compreender como ajudar o outro a se desenvolver como ser humano, significa valorizar e ajudar a desenvolver capacidades". É um ato em relação ao outro que implica procedimentos específicos. 
Ainda em 1999 e reeditada em 2010 foram elaboradas as Diretrizes Curriculares Nacionais para Educação Infantil as quais estabelecem princípios, fundamentos e procedimentos para orientar as propostas pedagógicas das instituições de educação infantil no país.

Pode se verificar que muitos anos se passaram desde as primeiras instituições, muitos movimentos sociais aconteceram para mudar a realidade a qual se encontrava essa etapa da educação a fim de proporcionar um atendimento de qualidade e garantir o direito das crianças à educação. Essa luta foi propulsora de diversificadas mudanças em leis que passaram a identificar a criança como sujeito de direitos, e que precisa ser desenvolvida em todos seus aspectos valorizando e respeitando suas particularidades.

\section{OS AVANÇOS E DESAFIOS DA EDUCAÇÃO INFANTIL NO BRASIL}

As primeiras instituições de educação infantil surgiram como uma resposta à situação de abandono e maus tratos a que as crianças eram submetidas devido à expansão da industrialização que levou muitas mulheres a buscarem emprego e deixarem seus filhos aos cuidados de outras mulheres ou com irmãos mais velhos.

Essas instituições foram criadas com uma proposta assistencialista, já que eram destinadas às famílias cujas mães necessitavam trabalhar e não tinham com quem deixar seus filhos.

No Brasil, até o início do século ainda se tinha a ideia de que o atendimento as crianças era um favor, uma caridade. Sendo assim, organizações sociais e filantrópicas e donos de empresas tentavam construir um aparato para atender os filhos das operárias sob $o$ intuito de que elas pudessem se reproduzir satisfatoriamente enquanto forças de trabalho (PASCHOAL; MACHADO, 2009)

Historicamente o desenvolvimento da educação infantil passou pela concepção e atendimento em creches e pré-escolas mais assistencialistas que educativas em que o importante era a alimentação e o cuidado com a saúde. Esse formato de atendimento deixava claro que se destinava a camada mais pobre da população.

No entanto, no século $X X$, iniciaram-se alguns protestos $e$ reivindicações por melhores condições de trabalho e por creches para atendimento dos filhos desses trabalhadores. Cada vez mais a mulher participava do mercado de trabalho e prevalecia os problemas para a conciliação do trabalho com atendimento dos filhos.

As instituições de educação infantil eram propostas como meio para diminuir os conflitos sociais, e também como um meio de educação para uma sociedade igualitária. A ampliação do trabalho feminino leva também a classe média 
a procurar instituições educacionais para seus filhos. Sendo assim, o atendimento educacional às crianças passa a ganhar legitimidade social não só para os filhos dos pobres (KUHLMANN JR, 2000, p.11), uma vez que surge o atendimento dos centros de convivência infantil para atender filhos de diversos setores da sociedade.

Os estudos demonstraram que a sociedade brasileira tem protagonizado nas últimas décadas diversas transformações na legislação referente às políticas públicas dirigidas à infância, enfatizando o direito ao atendimento de qualidade às crianças de zero a cinco anos, agora como responsabilidade da educação e não mais da assistência, como historicamente foi constituída.

Contudo, a realidade vem mostrando o hiato existente entre a legislação e sua efetiva concretização através de políticas públicas, revelando a manutenção da política de convênios com instituições filantrópicas em alguns municípios. Segundo Pinto (2016) o risco que está por trás dessa opção de atendimento é o comprometimento da qualidade, uma vez que os valores repassados geralmente ficam muito abaixo das estimativas feitas, por exemplo, para o Custo Aluno-Qualidade inicial (CAQi), previsto no Parecer CEB/CNE n 8/2010.

Segundo estudos de Borghi, Adrião e Garcia (2011) a criação do Fundeb contribuiu para a manutenção de convênios e parcerias entre o setor público e o privado na oferta de educação infantil, já que estabelece um coeficiente para creches e pré-escolas abaixo do valor das séries iniciais de ensino fundamental e dessa forma esse custo reduzido poderá implicar na qualidade do serviço prestado.

Estudos concluem também, que essa etapa da educação ainda perece de dois problemas, entre eles a de acesso e de qualidade do atendimento. Segundo Barreto (1998), mesmo tendo havido nas últimas décadas a expansão do atendimento a entrada da criança na creche, ainda deixa a desejar porque crianças de famílias de baixa renda têm menos oportunidade. Além disso, a autora ressalta que a qualidade:

As instituições de educação infantil no Brasil, devido à forma como se expandiu, sem os investimentos técnicos e financeiros necessários, apresenta, ainda, padrões bastante aquém dos desejados [...] a insuficiência e inadequação de espaços físicos, equipamentos e materiais pedagógicos; a não incorporação da dimensão educativa nos objetivos da creche; a separação entre as funções de cuidar e educar, a inexistência de currículos ou propostas pedagógicas são alguns problemas a enfrentar (BARRETO, 1998, p. 25).

Para se atingir a qualidade esperada é necessário que seja efetivada a formação de professores e estabelecido recursos financeiros destinados a essa faixa etária. Para isso surgiu em 2014 a lei no 13.005 que institui o Plano Nacional da Educação na qual um dos objetivos é assegurar que todas as crianças entre 4 e 5 anos devem estar matriculadas na pré-escola. 
A meta 6 propõe a oferta de atendimento com qualidade e prevê a adoção progressiva do atendimento em tempo integral em metade das escolas públicas do país.

É importante também pensar nos profissionais dessa faixa de ensino, uma vez que para se atingir as novas exigências previstas em lei esses profissionais necessitam de uma formação adequada e continuada. Portanto, de acordo como Paschoal e Machado "Em se tratando da criança pequena, a realidade tem apontado que ambas as formações é uma das variáveis que maior impacto causa sobre a qualidade desse tipo de atendimento" (2009, p. 90). Para os autores, como o currículo ainda é dividido por áreas dificulta qualquer mudança, sendo assim fica difícil que esse profissional conceba a criança de modo integrado, uma vez que em seu curso de formação os conteúdos se apresentam de forma fragmentada.

O currículo é um aspecto que deve ser levado em consideração, pois ele é um projeto coletivo que deve ser organizado com elementos que possam enriquecer o universo infantil.

\begin{abstract}
Planejar o currículo implica ouvir os profissionais em suas concepções e decisões, problematizar a visão deles sobre creches e pré-escolas, evitando perspectivas fragmentadas e contraditórias, que refletem a influência das várias concepções educacionais que vivenciaram ou com que tiveram contato. (OLIVEIRA, 2002, p. 168).
\end{abstract}

Ao falar sobre trabalho pedagógico o professor encontra muitas dificuldades "a própria literatura, quando aborda esta questão, centra-se mais no recorte de um ou outro aspecto que envolve o cotidiano da instituição, mas não fornece aos professores uma visão mais globalizante dos elementos que constituem o seu trabalho diário (PASCHOAL E MACHADO, 2009, p. 91).

\title{
2. CONSIDERAÇÕES FINAIS
}

Esse estudo possibilitou compreender a trajetória da história da educação infantil no Brasil e mostrar que através de lutas sociais essa etapa da educação alcançou depois de muitos anos um lugar de direitos a todos a uma educação de mais qualidade. Vê-se que as últimas décadas foi um tempo de conquistas para a educação de crianças já que o Estado se compromete através de leis a oferecer atendimento público a todas as crianças nessa faixa etária.

Apesar dos avanços estudos apontam que ainda há muito que se realizar nessa etapa no que tange a um atendimento de efetiva qualidade, entre eles, pode-se citar: recursos financeiros insuficientes, formação do professor que atenda a exigência de educar e cuidar ao mesmo tempo, projeto pedagógico que possibilite diferentes experiências, espaço físico adequado ao desenvolvimento das crianças, rotina estáveis e materiais diversificados. 
Sendo assim, pode se concluir de acordo com as pesquisas que muitos foram os avanços nessa etapa da educação, porém ainda vemos que muitos desafios acompanham a trajetória dessas instituições, uma vez que na prática ainda tem se serviços voltados a cuidados relacionados à higiene e alimentação em detrimento de um trabalho voltado aos aspectos educativos.

Dessa forma, é necessário que a educação infantil de qualidade seja reconhecida não só em legislações e documentos oficiais, mas que seja efetivada nas práticas e no cotidiano das instituições de educação infantil.

\section{REFERÊNCIAS}

BARRETO, Ângela M. R. Situação atual da educação infantil no Brasil. In: BRASIL. Ministério da Educação e do Desporto. Subsídios para o credenciamento e funcionamento de instituições de educação infantil. v. 2. Coordenação Geral de educação infantil. Brasília: MEC/SEF/COEDI, 1998.

BORGHI, Raquel F.; ADRIÃO, Theresa M. de F; GARCIA, Teise de O. As parcerias público-privadas para a oferta de vagas na educação infantil: um estudo em municípios paulistas. Revista Brasileira de Estudos Pedagógicos, v. 92, n. 231, p. 285-301, 2011.

BRANDÃO. Carlos da Fonseca. A educação infantil no Plano Nacional de Educação: a questão da oferta e do atendimento. In: PASCHOAL, Jaqueline. D. (Org.). Trabalho pedagógico na educação infantil. Londrina, PR: Humanidades, 2007. p.77-86.

Ministério da Educação e do Desporto. Secretaria de Educação Fundamental. Referencial curricular nacional para a educação infantil. Brasília, DF: MEC/SEF, 1998a.

KRAMER, Sonia. A política do pré-escolar no Brasil: a arte do disfarce. 5. ed. São Paulo: Cortez,1995.

KUHLMANN Jr., Moysés. Infância e educação infantil. Porto Alegre: Editora Mediação, 1998.

LOPES, Karina Rizek Lopes; MENDES, Roseana Pereira; FARIA, Vitória Líbia Barreto (Org.) Coleção PROINFANTIL. Brasília: MEC. Secretaria de Educação Básica. Secretaria de Educação a Distância, 2005.

OLIVEIRA, Zilma Moraes R. Creches: Crianças, faz de conta \& Cia. Petrópolis, RJ: Vozes, 1992.

Zilma Moraes R. Educação infantil: fundamentos e métodos. São Paulo: Cortez, 2002. (Coleção Docência em Formação). 
PASCHOAL, Jaqueline Delgado; MACHADO, Maria Cristina Gomes Machado. A História da Educação Infantil no Brasil: Avanços, retrocessos e desafios dessa modalidade educacional. Revista HISTEDBR On-line, Campinas, n.33, p.78-95, mar.2009

PINTO, José M. R.. Uma análise da destinação dos recursos públicos, direta ou indiretamente, ao setor privado de ensino no Brasil. Educação e Sociedade, v. 37, n. 134, Campinas, 2016.

RIZZO, Gilda. Creche: organização, currículo, montagem e funcionamento. 3. ed. Rio de Janeiro: Bertrand Brasil, 2003. 


\title{
ACOLHIMENTO COMO ESTRATÉGIA PARA PROMOÇÃO DA SAÚDE E QUALIDADE DE VIDA DE PESSOAS EM SITUAÇÃO DE RUA
}

\author{
OLIVEIRA, Leticia Natália de \\ Pós-Graduanda em MBA - Universidade de Franca. \\ nataliaoliveiraleticia@gmail.com \\ ALMEIDA JUNIOR, Silvio de \\ Mestrando - Universidade de Franca \\ silvioalmeidajr@yahoo.com.br \\ BULGO, Danilo Cândido \\ Docente - Universidade de Franca \\ danilobulgo@gmail.com
}

\section{INTRODUÇÃO}

Desde a década de 70, estudos brasileiros têm analisado intensamente a pobreza urbana. Espaços urbanos ocupados por grupos sociais, em decorrência da pobreza e falta de moradia ou de infraestrutura, foram caracterizados como "periferias" - espaços socialmente homogêneos, "esquecidos" pelas políticas estatais, e localizados em sua grande maioria nas extremidades dos centros urbanos.

No entanto, Torres (2003) evidencia que atualmente a homogeneidade e a localização das periferias têm sido revistas em vários aspectos, principalmente no que diz respeito ao processo de disseminação da pobreza e de pobres por toda a cidade, levando a criação de mais periferias, por consequência de invasões de pequenos espaços, não ocupadas pela urbanização, entre pontes e margens de rios ou linhas férreas.

Carneiro e Veiga (2004) definem vulnerabilidade como exposição a riscos e baixa capacidade material, emocional e comportamental de famílias e pessoas para enfrentar e superar os tantos desafios.

Neste meio existem famílias que migram de outros estados do país para grandes metrópoles, ou do campo para a cidade, em busca de oportunidades de reconstruir suas vidas, mas durante esta procura, sem muito subsidio para continuarem vivendo, como habitação e alimentação, se deparam com a situação de rua. Porém, neste âmbito, outra população compreende "a rua" como um local de extrema liberdade de existência, apensar de todos os riscos. 
O conceito descrito no Decreto $\mathrm{n}-7.053 / 2009$, que regulamenta a Política Nacional da População de Rua (PNPR), define essa população como:

\footnotetext{
"Grupo populacional heterogêneo que possui em comum a pobreza extrema, os vínculos familiares interrompidos ou fragilizados e a inexistência de moradia convencional regular, e que utiliza os logradouros públicos e as áreas degradadas como espaço de moradia e de sustento, de forma temporária ou permanente, bem como as unidades de acolhimento para pernoite temporário ou como moradia provisória." (BRASIL, 2009, p.16).
}

Com mais entendimento deste fenômeno da Pessoa em Situação de Rua (PSR), faz-se necessária compreender como se dá o processo de "exclusão social", refletindo assim a sua origem, que se observarmos minuciosamente, aparenta estar interligada ao renascimento das cidades, fruto do surgimento do capitalismo (CRP, 2015).

No livro "No Meio Da Rua: nômades, excluídos e viradores", Bursztyn (2000, p.20) nos permite ter uma vasta visão da influência da globalização para com essas pessoas, em que são "jogadas para fora" do sistema, sendo excluídas do processo de riqueza (emprego) e da distribuição de frutos (consumo), sobrevivendo com o acesso precário a mecanismos públicos, como a assistência social e os serviços de saúde, e de forma assistemática, contando com o auxílio de entidades filantrópicas ou religiosas.

\subsection{Políticas Públicas Específicas}

Frente às necessidades advindas da falta de amparo perante as pessoas em situação de vulnerabilidade, faz-se necessário à criação de políticas públicas efetivas e equipamentos/serviços eficazes que auxiliem na adoção de medidas que maximize a visão para este perfil populacional.

Esse panorama se alterou em passos lentos, a partir do fim de 1987 através da Constituição Federal de 1988, na qual proferiu os direitos sociais como direitos fundamentais de todo indivíduo, e com a Lei Orgânica da Assistência Social (LOAS) decretada em 07 de dezembro de 1993, que regulamentou os artigos 203 e 204 da Constituição Federal, reconhecendo a Assistência Social como política pública. Com base na atual legislação, o poder público passou a ter a tarefa de manter serviços e programas de atenção à população de rua, garantindo à estas pessoas, padrões éticos de dignidade e de direitos de cidadania (BRASIL,1993, s/p).

Assim, pensando em tantas necessidades, foi implantada a Política Nacional para a População em Situação de Rua - PNPR, instituída pelo Decreto no 7.053, de 23 de dezembro de 2009, que visa assegurar o acesso ampliado, 
simplificado e seguro aos serviços e programas que integram as diversas políticas públicas desenvolvidas pelos nove ministérios que o compõem (BRASIL, 2009, s/p).

A PNPR, além dos princípios da universalidade, igualdade e equidade, garante a participação e controle social, o respeito à dignidade da pessoa humana; o direito à convivência no seio familiar e integração social; a valorização e respeito à vida e à cidadania; o atendimento humanizado e integral; e o respeito às diversidades étnico e cultural, raça, idade, nacionalidade, gênero, orientação sexual e religiosa, com atenção especial às pessoas com deficiência (BRASIL, 2009, s/p).

Visando ampliar o acesso desde grupo populacional, o Centro de Referência Especializado para Pessoas em Situação de Rua, constitui-se como um dos principais equipamentos voltado para o atendimento especializado à população em situação de rua, com o intuito de oferecer serviço e atendimentos individuais e coletivos aos moradores de rua, adultos, de ambos os sexos, que chegam espontaneamente ou encaminhados pela rede de atendimento.

O Centro POP, enquanto uma unidade de referência da proteção social especial de média complexidade atua com equipes interdisciplinares, proporcionando um espaço de referência para as pessoas em situação de rua, onde podem se alimentar, cuidar de sua higiene pessoal, participar de oficinas e grupos de acolhimento, além de receberem encaminhamentos para outros serviços e para obtenção de benefícios, documentação, e até mesmo cuidados com a saúde. Estas Unidades também representam um espaço de referência para o convívio social e o fortalecimento de vínculos que corroboram para o incentivo da solidariedade, afetividade e respeito, desenvolvendo assim a consciência crítica com relação à cidadania, seus direitos e também deveres (SCLIAR, 2005).

Assim, pensando nas metas propostas pela Agenda 2030, no qual aponta 17 Objetivos de Desenvolvimento Sustentável (ODS) para melhorias relacionadas ao plano de ação para as pessoas, para o planeta e para a prosperidade. Os ODS buscam o fortalecimento da paz universal com maior liberdade. Diminuindo a erradicação da pobreza em todas as suas formas e dimensões, abarcando a pobreza extrema, é o maior desafio global e um requisito indispensável para o desenvolvimento sustentável. Corroborando com o presente estudo, o Objetivo 10 da Agenda 2030 visa reduzir a desigualdade dentro dos países e entre eles. Na meta 10.2 aponta o empoderamento e promoção da inclusão social, econômica e política de todos, independentemente da idade, gênero, deficiência, raça, etnia, origem, religião, condição econômica ou outra (ONU, 2015).

O objetivo do presente trabalho é realizar uma intervenção por meio de instrumentos e métodos adequados com a população em situação de rua que vão ao Centro de Referência Especializado para Pessoas em Situação de Rua - Centro POP, localizado em uma cidade de médio porte do interior Paulista, por meio de rodas de conversa, objetivadas em fornecer informações referentes à instituição e realizar possíveis encaminhamentos para profissionais especializados em situações 
específicas, promovendo uma maior interação social entre os usuários e a equipe de funcionários presentes na instituição.

\section{METODOLOGIA}

A metodologia aplicada na construção deste artigo foi baseado em estudo exploratório, segundo Dencker (1998), utilizou-se fontes secundárias e observação informal. Foi elaborado um cronograma de atividades objetivadas em proporcionar a acolhida aos novos usuários, através de grupos de rodas de conversa e posteriormente realizar a triagem para que seja preenchido o cadastro do usuário no sistema da instituição. Os encontros semanais foram executados às sextas-feiras das $08 \mathrm{~h} 00$ às $11 \mathrm{~h} 00$.

A instituição conta com um grande número de usuários que procuram os demais serviços oferecidos todos os dias, porém o Grupo Acolher foi integrado por novos usuários que procuravam o Centro Pop naquele dia, justamente para proporcionar a acolhida dos mesmos. O Grupo contou com a participação de uma equipe multidisciplinar, no qual participaram e contribuíram para a realização dos encontros, como as psicólogas e assistentes sociais que nos acompanharam.

Os instrumentos utilizados para mediar a intervenção foram técnicas de grupo, conversas informais acerca de discussões reflexivas. Foram propostas atividades que corroboram com a ida dos indivíduos ao local no estudo.

\section{RESULTADOS E DISCUSSÃO}

As atividades foram realizadas a partir da demanda já existentes na instituição e foram moldadas a partir das necessidades do estágio. No primeiro contato com a instituição, toda a equipe se mostrou muito receptiva e aberta com a nossa chegada. Fomos recebidas pelas psicólogas do Centro POP, que proporcionaram uma rica conversa para nos explicar o funcionamento, as políticas que regem os serviços, a missão e também expor as atividades que são realizadas pelos profissionais.

Desde o início da intervenção, foi observado a importância do respeito e assistência humanizada de uma equipe multidisciplinar para com a população que vive em extrema vulnerabilidade, principalmente quando nos referimos à pessoa em situação de rua, levando em consideração sua história, vivências e singularidades.

Neste âmbito, Barros at al. (2017, p.7) considera que a humanização da saúde é uma maneira de aproximar-se do indivíduo nos momentos difíceis, delicados e de grande sofrimento, percebendo-a em sua totalidade de ser humano autônomo e responsável, ao escutá-lo com respeito, oferecendo igualdade na abordagem. 
Durante as intervenções houve interação com a equipe e com estagiários de demais áreas de atuação do Serviço Social, tendo um papel muito importante nos momentos do grupo ou do cadastro das fichas dos novos usuários. Contudo, as pessoas que foram selecionadas para participar do Grupo Acolher, foram aqueles que estavam presentes no Centro POP pela primeira vez, pois precisavam ser acolhidas e cadastradas no sistema da instituição.

Neste âmbito Hino P, Santos JO, Rosa AS (2018, p. 733), ressaltam:

" [...] tomando como parâmetro o tempo de permanência na rua, a relação com esse contexto de vida e os vínculos familiares, a população que vivencia situação de rua pode ser classificada em três situações diferentes: ficar na rua (circunstancialmente), estar na rua (recentemente) e ser da rua (permanentemente)".

Nos primeiros encontros, a psicóloga se propôs em direcionar o grupo, pois já havia vivenciado experiências parecidas em outros projetos desenvolvidos, mas também nos deixou livres para propiciarmos reflexões em torno das vivências trazidas pelos participantes, proporcionando assim momentos de escuta e troca de experiências.

Após alguns dias de contato com a rotina do Centro, observamos que a proposta inicial de trabalho seria "expandida" para abarcar as demandas da instituição, com o intuito de aproximar a prática acadêmica com o trabalho já desenvolvido no local. A partir dessa observação foi estabelecido que em cada encontro iniciaríamos o Grupo Acolher e posteriormente faríamos o cadastro das fichas dos participantes.

O Centro POP disponibiliza uma entrevista padrão semiestruturada para ser realizada, onde contém as informações mais gerais até o motivo que levou a pessoa a procurar o serviço.

Vivências trazidas pelos participantes foram extremamente importantes para o seguimento do grupo, pois a partir do que era exposto por cada pessoa, íamos fornecendo informações referentes aos serviços que eram oferecidos na casa e por outros setores da assistência social, ressaltando sempre os deveres que precisavam ser cumpridos por eles, para receberem tais atendimentos, como o atendimento médico, e serem encaminhados para serviços específicos na assistência à população em situação de rua.

A criação da Portaria no. 122, da diretriz de organização e funcionamento das equipes de Consultório na Rua, publicada em 2011 pelo Ministério da Saúde, contribuiu para ampliar e maximizar o acesso das pessoas em situação de rua aos serviços de saúde e, assim atender melhor às demandas de saúde dessa população. (BRASIL, 2012).

Com o avançar dos encontros, fomos nos familiarizando com as atividades e desenvolvendo nossa escuta qualificada, ponto chave nos momentos 
da entrevista e triagem para o cadastro das fichas dos usuários. Nestes momentos "filtramos" os relatos trazidos pelo usuário, para podermos realizar os apontamentos pertinentes e possíveis encaminhamentos. Este "filtro" também demonstra a maneira de acolher a história trazida pela pessoa, nos afastando das "representações sociais" e compreendendo a subjetividade de cada um.

Observamos "representação social", neste contexto, como a categoria definida por Jodelet (2001), sendo,

"[...] uma forma de conhecimento, socialmente elaborada e partilhada com um objetivo prático, e que contribui para a construção de uma realidade comum a um conjunto social. Igualmente designada como saber de senso comum ou ainda saber ingênuo, natural, esta forma de conhecimento é diferenciada, entre outras, do conhecimento científico" (JODELET, 2001, p. 22).

Ao nos aproximarmos das vivências dos participantes, identificamos que, por mais que a condição de extrema vulnerabilidade seja similar em ambos os casos atendidos, os motivos pelos quais a pessoa recorreu viver na rua, ou no trecho (permanecendo em várias cidades em um curto período de tempo), são distintas, no entanto todos os usuários que participaram do grupo ou somente do cadastro, relataram ter vínculos rompidos com seus familiares (pai/ mãe/esposa/filhos ou irmãos).

Além disso, pode-se dizer que parte da problemática das pessoas atendidas está relacionada com o desemprego e também uso de álcool de outras drogas. Muitos relataram estarem nesta situação, pois não tem possuem vínculos e estão em busca de emprego, mesmo que seja informal. Já outros mencionaram viver nestas situações devido ao vício, que acarretaram ao rompimento do vínculo com suas redes de apoio.

Ademais, foram realizadas rodas de conversa focadas em questões trazidas pelos participantes do Grupo, proporcionando momentos de sociabilidade, troca de experiências e reflexões. Estes momentos em grupo também permitiam a integração com demais profissionais, como por exemplo, a assistente social, que nos auxiliou em realizar os encaminhamentos, dialogando também com o usuário.

Entre todas as atividades, destacamos um encontro, no qual dois participantes se emocionaram em expor suas vivências e o que os motivou a procurar o auxílio do Centro POP, um dos participantes informou que vivia em situação de rua há cerca de cinco meses, porém não queria continuar vivendo assim, pois precisava conseguir um emprego, e se emocionou muito em dizer que "não confiaria mais no homem, pois foi se deu muito mal", explicou-nos que foi enganado pelo seu irmão e por isso se encontra nesta situação. O outro participante, também muito emocionado ao ouvir, relata que gostaria de auxílio para ser encaminhado para o tratamento de dependência química, pois ainda deseja reatar seu casamento e se aproximar de sua filha. 
O olhar atento sobre a realidade de cada indivíduo permite-nos observar como a troca de experiências e o diálogo podem influenciar nas percepções sobre si mesmo, sobre nosso presente e principalmente em um possível futuro.

Em 1948 a Organização Mundial de Saúde ampliou o conceito da palavra saúde, tornando-a como o "mais completo bem-estar físico, mental e social e não apenas a ausência de enfermidade" (OMS, 1948).

Anos depois na Primeira Conferência Internacional sobre Promoção da Saúde, surge um importante documento nomeado de "Carta de Ottawa", consagrada no Canadá, 1986, que em seu corpo textual define alguns pré-requisitos fundamentais para a saúde, sendo eles: paz; habitação; educação; alimentação; renda; ecossistema estável; recursos sustentáveis; justiça social; equidade (BRASIL, 2002, p.20).

Nessa perspectiva, a promoção da saúde surge como um conjunto de estratégias e ferramentas que visam reduzir as iniquidades em saúde, ampliando o empoderamento e a garantia de oportunidades a todos os cidadãos de fazerem escolhas mais favoráveis, serem atores no processo de produção da saúde e buscar por melhorias da qualidade de suas vidas, tanto no âmbito individual quanto coletivo (BUSS, 2009).

Fleck et al. (2003) afirma que a Psicologia se destaca no campo científico e social, proporcionando condições que possam interferir no bem-estar dos indivíduos, associados a fatores relacionados à qualidade de vida, no intuito de propor alternativas de intervenção elaborando ações e políticas no âmbito da saúde, visando atender às demandas da população.

A partir de todas essas informações podemos compreender que a Instituição apresentou muito interesse e disposição em dar continuidade às atividades elaboradas e realizadas pelas estagiárias atuantes no Grupo Acolher.

\section{CONSIDERAÇÕES FINAIS}

Conviver com a vulnerabilidade social, pode aproximar diversos profissionais em relação as ações comunitárias, realizando o trabalho junto às pessoas que não são vistas pela sociedade formal, de forma humanizada e singular para cada situação. A equipe multiprofissional, deve exercer suas práticas laborais baseadas no acolhimento, empatia e liberdade. Embora o convívio com a instituição tenha sido realizado em um período de quatro meses, existiu entre profissionais e usuários do serviço uma troca rica de experiências, elevando a qualidade de vida e o empoderamento dos cidadãos. A partir dessas vivências, pudemos resignificar 0 olhar para "o morador de rua, ou andarilho", que em contrapartida, tivemos a possibilidade de negar estas nomenclaturas que excluem suas identidades, atribuindo a essas pessoas a condição histórica de lutar junto a nós para a 
transformação desta realidade social, a fim de produzir serviço de todas as classes para construir, junto com elas, uma sociedade que saiba reproduzir a equidade.

\section{REFERÊNCIAS}

ABREU, M. A. Evolução urbana no Rio de Janeiro. 1987.

BARROS, M. D. F. F; LEAL, C. S; SILVA, V. Assistência humanizada à pessoa idosa com dificuldade de comunicação: atuação do psicólogo em um hospital universitário de São Luís-MA. Novas Edições Acadêmicas, 2017, p.07.

BRASIL. Decreto № 7053, de 23 de dezembro de 2009, institui a Política Nacional para a PSR e seu Comitê Intersetorial de Acompanhamento e Monitoramento, e dá outras providências. Diário Oficial da União, Brasília, 24 dez. 2009, p.16-17. Disponível em: < http://www.planalto.gov.br/ccivil_03/_ato20072010/2009/decreto/d7053.htm>. Acesso em: 09 maio de 2019

BRASIL. Ministério da Saúde. Portaria n0 122 de 25 de janeiro de 2011. Define as diretrizes de organização e funcionamento das equipes de Consultório na Rua. Diário Oficial da União;2012.

Brasil. Ministério da Saúde. As Cartas da Promoção da Saúde. Secretaria de Políticas de Saúde, Projeto Promoção da Saúde. Brasília: Ministério da Saúde, 2002.

BURSZTYN, M. et al. No meio da rua: nômades, excluídos e viradores. Rio de janeiro: Garamond, p. 19-26, 2000.

BUSS, P.M. Carvalho AI. Desenvolvimento da promoção da saúde no Brasil nos últimos vinte anos (1988-2008). Cien Saude Colet 2009; 14(6):2305-2316.

CARNEIRO, C. B. L; VEIGA, L;. O conceito de inclusão, dimensões e indicadores. Belo Horizonte: Secretaria Municipal de Coordenação da Política Social, 2004.

CONSELHO Federal de Psicologia, Psicologia-Legislação. Resolução CFP № 05/2003. Art. 3․ I. Substituída pela CFP №13/2007. Disponível em: <https://site.cfp.org.br/wp-content/uploads/2006/01/resolucao2003_5.pdf>. Acesso em 21 abril de 2019. 
EDUCAÇÃO E POLÍTICAS PÚBLICAS EM VIESES

FLECK, M. et al,. Projeto WHOQOL-OLD: método e resultados de grupos focais no Brasil. Revista de Saúde Pública, v. 37, p. 793-799, 2003.

HINO, P; DE OLIVEIR. S. J; DA SILVA R. A. Pessoas que vivenciam situação de rua sob o olhar da saúde. Revista Brasileira de Enfermagem, v. 71, 2018.

JODELET, D. As representações sociais. Rio de Janeiro: Ed. UERJ, 2001, p.22.

LANE, S. T.M; BOCK, A. M. B. ABRAPSO: Uma história da psicologia social enquanto práxis. Psicologia social: relatos na América Latina, p. 145-155, 2003.

MEDEIROS, L, et al. Um breve histórico da psicologia jurídica no Brasil e seus campos de atuação. Estudos de Psicologia, v. 26, n. 4, p. 483-491, 2009.

SCLIAR, C. Ministério do Desenvolvimento Social e Combate à Fome. 2005.

TORRES, H. G. et al. Pobreza e espaço: padrões de segregação em São Paulo. Estudos avançados, v. 17, n. 47, p. 97-128, 2003. 


\title{
ARQUITETURA E EDUCAÇÃO: A função social da arquitetura e seu aporte aos espaços educativos
}

\author{
SOUZA, Letícia de Paula \\ Graduanda em Arquitetura e Urbanismo - UFU \\ lepaulasouza@gmail.com
}

\author{
GARREFA, Fernando \\ Doutor em Arquitetura e Urbanismo - USP \\ fgarrefa@ufu.br
}

\section{INTRODUÇÃO}

A arquitetura e a ocupação dos espaços são sempre mutáveis, desde a construção à localização, expressando uma expectativa de comportamento dos seus usuários. Neste sentido, o edifício escolar ganhou grande relevância ao longo de sua história. Consolidado a partir da Idade Média, as alterações ocorridas no perfil das instituições escolares modificaram os seus espaços e novas condicionantes projetuais foram desenvolvidas, refletindo assim em sua tipologia.

Assim, como coloca Giselle Arteiro Nielsen Azevedo (2002), a escola é o primeiro espaço que insere a criança numa experiência coletiva. Logo o espaço escolar reflete uma dinâmica de relações que ultrapassa a noção tridimensional para um espaço significativo de "lugar", reconhecido e vivenciado por seus usuários.

Diante disso, a concepção do edifício escolar é considerada de grande importância a partir do seu significado social, objeto emblemático inserido no tecido urbano, bem como no seu processo educativo. Para tanto, a relação espaço-usuário é um parâmetro fundamental para a concepção projetual, visto que a junção das duas áreas agrega no nível de conhecimento e relação com as pessoas.

Com esta concepção, a arquitetura contribui incisiva e racionalmente para projetar e reorganizar os espaços, como em destaque, o espaço escolar. Neste contexto, se destaca a reflexão sobre um processo projetual que relacione 0 ambiente àqueles que o vivenciam e vise e versa. Isto é, considerando seu desempenho e bem-estar do usuário, entendendo o espaço físico essencial para o desenvolvimento de uma filosofia pedagógica e do suporte da edificação para efetivação dos significados sociais.

Por isso, a adequação do edifício escolar à proposta pedagógica adotada é conduzida a partir dos conhecimentos reais das necessidades dos usuários, valores e expectativas, já que é nesse ambiente que a criança irá se desenvolver, estabelecendo interações e participações com o mundo e com outras pessoas. 
A partir do destacado, o escrito foi baseado em uma bibliografia de investigação sobre o tema, dividido em dois capítulos. Inicialmente, aborda-se a questão da contribuição do arquiteto e urbanista para a formação de um espaço social na cidade. Já por último, parte-se para uma breve discussão entre o espaço escolar enquanto projeto arquitetônico e pedagógico, partindo para sua reflexão a partir das relações estabelecidas na edificação para melhor desempenho educacional e social.

\section{ARQUITETURA E A CONSTRUÇÃO DO ESPAÇO SOCIAL}

Diferente de outras concepções de espaços em outros campos disciplinares, o espaço arquitetônico se define por um vazio que constitui em consequência de uma ação humana compositiva (COUTINHO, 1977). Neste sentido, quando nos referimos a construção do espaço social, não podemos destacar apenas a sociedade como referência de indivíduo, mas sim as necessidades do grupo em comum.

Assim, entendendo o sentido etimológico da palavra arquitetura (architektôn) compreende-se sua proposição humana (arkhê) e compositiva (tektôn), ou seja, o fazer arquitetônico é um lugar projetualmente humano. Isto quer dizer, que a arquitetura cumpre a função de criar espaços que permitem a interação e convivência do ser humano em sociedade. Em temos práticos, entende-se que a função da arquitetura, seria a de traduzir em termos de espaço e tempo uma ideia ou princípio gerador, com um potencial de síntese de valores subjetivos que são determinantes à sua formalização concreta enquanto espaço construído (LORENTZ, 2016).

Historicamente, desde a Revolução Industrial houve uma mudança significativa no crescimento das cidades atrelado ao populacional e, assim, as necessidades humanas foram mudando em relação aos espaços. Contudo, não foi somente neste período que as pessoas começaram a necessitar de outros espaços, uma vez que foi sempre presente desde a antiguidade, no qual tem-se como exemplo a ágora e foro como espaços de convivência e relações sociais.

Deste modo, a compreensão da arquitetura refletida no espaço construído é explorada há anos e opera como mediador entre o indivíduo e o seu contexto. Logo, tomando a definição de Martin Heidegger por Norberg Schulz (2003), a ideia de existência humana gira em torno da ideia de ser-no-mundo (Dasein), e ao habitar propicia o homem um reconhecimento materializado em um objeto - um espaço construído - criando um vínculo de identidade entre o usuário e o lugar.

Nessa condição, mesmo sendo recorrente a imagem da casa quando tentamos descrever o espaço existencial, a mesma estrutura se aplica também as demais formas e lugares. Dessa forma, fica claro a construção de espaço social está 
relacionada, sobretudo, a construção de um espaço que torne visível os valores e a cultura de uma determinada comunidade. O objetivo da arquitetura, portanto, conforme colocado por Rafael De Conti Lorentz (2016, p.100) "seria justamente o de concretizar genius loci de cada situação específica, criando um espaço construído no qual o homem seja capaz de projetar a sua identidade".

Diante disso, da mesma raiz latina que deriva a palavra cidade, também temos cidadão, civilidade e cidadania. Sendo assim, esta última nos remete as características ou qualidades do indivíduo e, portanto, a capacidade que a cidade ou qualquer outro espaço construído tem de promover um vínculo de identidade com o usuário torna-se a sustentação da cidadania em determinado corpo social.

Nesse mesmo pensamento, o privado ou coletivo são colocados em constante conexão, estimulando a convivialidade e apreensão do senso de coletividade frente à civilidade. Para tal, entender a importância do papel do indivíduo como protagonista da sociedade em que se insere, implica no restabelecimento do vínculo de identidade que fundamentará a atuação da cidadania e, consequentemente, a construção do espaço social.

A construção do espaço social é entendida enquanto relações entre as pessoas, diante do qual se sobrepõe a igualdade coletiva e uma possibilidade de estabelecer conexões afetivas. Ou seja, o espaço social é concebido como um espaço multidimensional de posições que constituem um conjunto de relações ou um sistema de posições socias que se definem umas em relação às outras.

A propósito, o espaço aqui colocado pressupõe atribuição de sentido e deve ser compreendido como mais amplo do que sua delimitação física, produzido a partir de práticas sociais, nessa lógica, Henri Lefbvre (1991, p. 73) conceitua que:

\footnotetext{
Espaço social não é uma coisa entre outras coisas, nem um produto entre outros produtos: em vez disso, subsume coisas produzidas, e abrange suas inter-relações em sua coexistência e simultaneidade a sua ordem (relativa) e/ou (relativa) desordem. É o resultado de uma sequência à instancia de um mero objeto. Ao mesmo tempo, não há nada imaginado, irreal ou "ideal" sobre ele, em comparação, por exemplo, com a ciência, representações, ideias ou sonhos. Sendo em si o resultado de ações passadas, o espaço social é o que permite que novas ações ocorram, enquanto as sugestiona ou as proíbe. [...] O espaço social implica grande diversidade de conhecimento.
}

No contexto apresentado pelo autor, observa-se que o espaço está para as vivencias, assim como a forma está atrelado com suas funções e estrutura. Ainda nessa consideração, Milton Santos (2006) coloca que o espaço está intrinsicamente atrelado às práticas humanas, "formado por um conjunto indissociável, solidário e também contraditório, de sistemas de objetos e sistemas de ações, não considerados isoladamente, mas como o quadro único no qual a história se dá" (p. 36). 
Resta claro que o exercício profissional do arquiteto se coloca na intersecção de duas vertentes: a técnica e a intencional, através da organização do espaço físico e também da decodificação destes como lugares identitários resultante das relações afetivas das pessoas com o meio. Assim, como pondera Rodrigo de Azambuja Brod e Jane Márcia Mazzarino (2015) é preciso na hora de projetar ou compreender o lugar, vivenciá-lo, apreender como se significa a partir dos seus interlocutores, articulando posições e referências físicas e afetivas, histórias e relações construídas e incorporadas, seus usos e práticas. Sendo assim, entender a materialização do espaço construído baseado no indivíduo, simultaneamente está se falando em espaço social.

\section{ARQUITETURA ESCOLAR: Sua relação arquitetônica e pedagógica para um espaço significativo e social}

A partir do entendimento de Giselle Arteiro Nielsen Azevedo (2002), a escola é o primeiro espaço que insere a criança numa experiência coletiva. Neste sentido, o espaço escolar pode ser observado pela lógica estabelecida ao papel profissional do arquiteto no meio construído, ou seja, de responder as expectativas e necessidades do usuário do ponto de vista identitário e de propiciar relações.

Assim, entender a lógica do espaço educativo corresponde a refletir acerca da importância do ambiente físico para a prática educativa e, consequentemente, para a formação e desenvolvimento da criança, destacando a estrutura social onde ele existe, o que ele reflete e suporta, e suas significâncias simbólicas (LIMA, 1989). Para além de abrigar fisicamente seus usuários, o prédio escolar deve dar suporte e material para o ensino e aprendizagem, propondo soluções espaciais. Para isso, à percepção ambiental sinalizam as interações existentes entre o homem e o ambiente a partir da compreensão de seus significados e simbolismos, relacionando a percepção, cognição e comportamento (AZEVEDO, 2002).

Sob essa ótica espacial do lugar educativo, a relação entre espaço e educação é antiga. A transmissão do conhecimento de um povo e formação dos indivíduos foram conduzidas na antiguidade em locais construídos para outros fins, como templos religiosos, residências, entre outros ou ao ar livre. Posteriormente, na Idade Média começa a ser concebidos em edifícios específicos, que assim passam a ganhar ambientes próprios, com nova articulação e simbologia.

Porém, ainda em constante mudança, na primeira metade do século $X X$ a escola ganha um novo significado, graças a possibilidade de o aluno conduzir seu próprio aprendizado e, assim, aprender a aprender. O papel da escola seria de criar um ambiente que despertasse o interesse e criasse estímulos para as 
atividades dos alunos (AZEVEDO, 2002). Nessa prática, fica evidente a materialização do espaço baseado no indivíduo e atribuição de sentido e identidade.

Como referência desse novo modelo educacional, a médica italiana Maria Montessori, na virada do século XIX para o XX, criou um sistema reconhecido pelo seu próprio nome, que propunha espaços e atividades que gerassem maior liberdade em relação aos sistemas anteriores de educação. Dessa maneira, sua proposta era o aprendizado baseado nas atividades que a criança consegue exercer de acordo com o grau de dificuldade. Este "modelo preparado" denominado por ela, tinha por objetivo favorecer a atividade da criança de maneira correta, tornar o aluno independente do adulto tanto quanto possível, permitir que cada um caminhe dentro do seu próprio ritmo e enseje a troca de experiencia entre aprendizes de diferente idades, isto é, a favor da liberdade e individualidade (NASCIMENTO, 2012).

Logo, a arquitetura escolar traz uma nova discussão no âmbito educacional: o bem-estar dos usuários e suas relações com o ambiente. Dessa forma, como colocado por Sheila Pérsia do Prado Cardoso Melatti (2004), a concepção do espaço e a influência dos materiais poderá interagir com os alunos e educadores e criar um ambiente agradável e estimulante.

Conforme este cenário, sob olhar do profissional de arquitetura, a escola é entendida como espaço social em duas dimensões, a institucional, por um conjunto de normas e regras e a cotidiana, que influi nas relações sociais entre os usuários. Nessa medida, a educação e seus processos são compreendidos para além dos muros escolares e vai se ancoras nas relações sociais, (DAYRELL, 1992, p. 2):

São as relações sociais que verdadeiramente educam, isto é, formam, produzem os indivíduos em suas realidades singulares e mais profundas. Nenhum indivíduo nasce homem. Portanto, a educação tem um sentido mais amplo, é o processo de produção de homens num determinado momento histórico.

A priori o espaço arquitetônico da escola expressa uma determinada concepção educativa, essencial enquanto coletivo. Neste sentido, Silvia Ferreira Santos Wolff (1996, p. 105 in NASCIMENTO, 2012, p. 27) coloca que:

A arquitetura, mais do que abrigar variadas funções da atividade humana, é suporte de conteúdos simbólicos. Através de suas formas os edifícios se caracterizam como símbolos destas mesmas funções. É por isso que ao longo da história aprendeu-se a decodificar a imagem da igreja, da mesquita, do prédio dos correios, da agência bancaria, do mercado e da escola, entre tantas outras tipologias arquitetônicas que se foram consolidando.

Entende-se, portanto, que o ambiente escolar é repleto de vivencias sociais e cognitivas que revelam uma dinâmica de relações que ultrapassam a mera noção de espaço tridimensional, passam assim, a ter uma significação de "lugar", reconhecido e vivenciado por seus usuários (AZEVEDO, 2002, p. 11). Neste caso, ao retratar a escola com essa significação de "lugar" estamos afirmando o que Brond 
e Mazzarino (2015, p.1) traz em sua discussão sobre lugares identitários, no qual segundo os autores, a relação entre espaço e construção de identidade se dá:

[...] através das práticas sociais que formam o que aqui serão chamados de lugares identitários: porções do espaço público definidas por sua significação e posição cultural, formadas a partir de processos singulares e subjetivos de codificação-decodificação e compreendidas a partir das relações sociais [...]

Dessa maneira, o projeto arquitetônico de uma instituição de ensino deve ser subordinado à criança e também à proposta de ensino atendido, o que contribui para lugares mais acolhedores. Então, como justifica Juarez Tarcísio Dayrell (1996), o processo de ensino/aprendizagem ocorre numa homogeneidade, estratégias e propostas educativas para todos, expressado na forma de conceber um projeto político pedagógico que vai informar os conjuntos das ações educativas, junto com o espaço escolar. Ao mesmo tempo, o autor coloca que (1996, p. 142):

[...] existe um outro nível, o das interações dos indivíduos na vida social cotidiana, com suas estruturas, com suas características próprias. É o nível do grupo social, onde os indivíduos se identificam pelas formas próprias de vivenciar e interpretar as relações e contradições, entre si e com a sociedade, o que produz uma cultura própria. É onde os jovens percebem as relações em que estão imersos, se apropriam dos significados que se Ihes oferecem e os reelaboram, boa a limitação das condições dadas, formando, assim sua consciência individual e coletiva.

Ao analisar o que a discussão trazida por Dayrell (1996), é possível identificar que todas as experiências vividas pelos alunos os constituem como indivíduos concretos, expressões de um gênero, raça, lugar e papeis sociais, de escalas e valores e, por isso, fazem parte de um processo educativo amplo. Ainda colaborando para esse pensamento, Hertzberger (1996) também faz considerações importante a respeito do espaço arquitetura, que "enquanto, por um lado, a estrutura representa o coletivo, por outro, a maneira como pode ser interpretada representa exigências individuais reconciliando assim o individual e o coletivo" (p. 106). Uma arquitetura que possibilite oferecer algo mais para os usuários, um valor potencial e adicional, que provoque associações que, interpretadas individualmente, possam gerar vários significados e, que, tenha a capacidade de adaptar-se à diversidade e à mudança, sem perder a sua identidade.

Por fim, para ilustrar o assunto discutido acima, tem-se o exemplo da Escola da Criança, localizada em Uberlândia - MG, projetada pelos arquitetos Maria Eliza Guerra e Roberto Andrade. Conforme uma análise feita pela Elza Cristina Santos (2011) a arquitetura da escola apresenta forte relação com a proposta construtivista de ensino adotada pela escola, uma delas é a criança construir seu conhecimento a partir de suas relações com o meio ambiente, promove a construção do saber por meio da pesquisa em todas as áreas do conhecimento (Figura 1) e também, com o lugar e comunidade. 
Além disso, segundo os próprios arquitetos, atendendo a proposta da pedagogia construtivista, três elementos primários da natureza (água, terra e fogo) foram incorporados simbolicamente ao projeto, materializados na praça da água, praça do fogo e praça da terra (horta). Ao analisar o projeto, observa-se que esses lugares se cruzam, estabelecendo quatro áreas importantes de aprendizagem, onde é possível a realização de diversas atividades lúdicas, deriocinadas ou não.

Á vista disso, o lugar representa um ponto que conectamos nossa identidade e, nesse aspecto, a construção da escola se enquadra nessa nova perspectiva pedagógica e arquitetônica enquanto espaço social. A partir da sua evolução projetual, buscou-se uma discussão entre o espaço útil ao cidadão usuário do espaço escolar - estabelecendo interações e participações com o mundo e com outras pessoas, motivando a convivialidade e reafirmando o papel do indivíduo como chave principal no meio que se insere, reafirmando assim, as práticas de identidade em prol de uma estrutura mais diversificada e que atenda as reais necessidades educacionais.

Figura 1 - Áreas externas da escola - espaços lúdicos e de aprendizado. 
a)

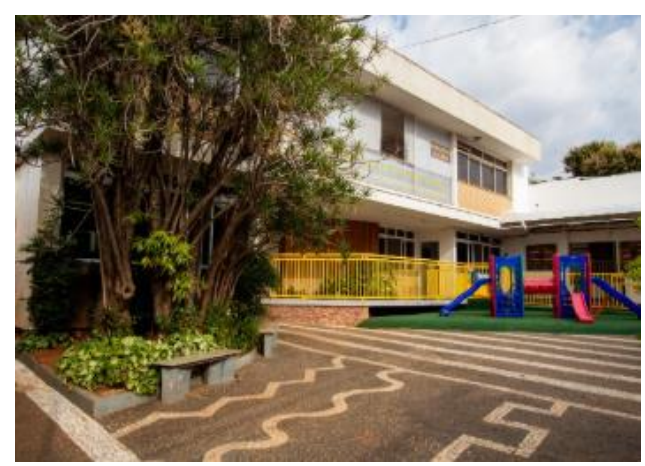

c)

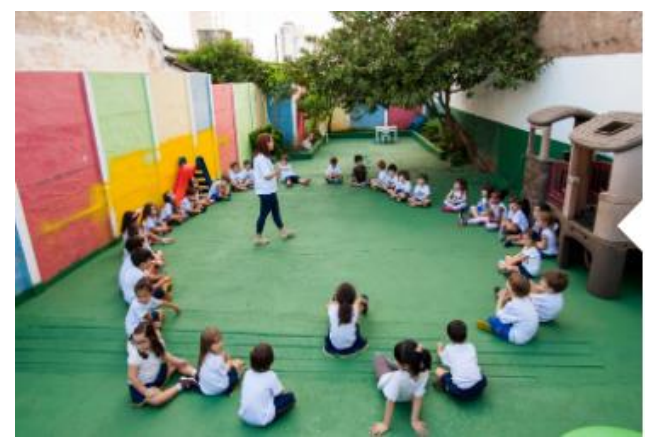

e)

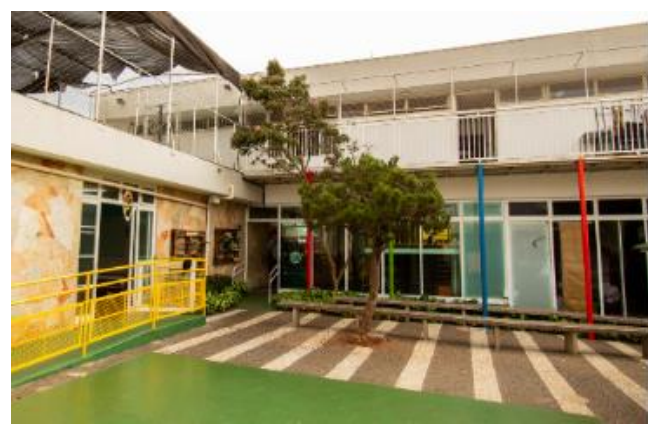

b)

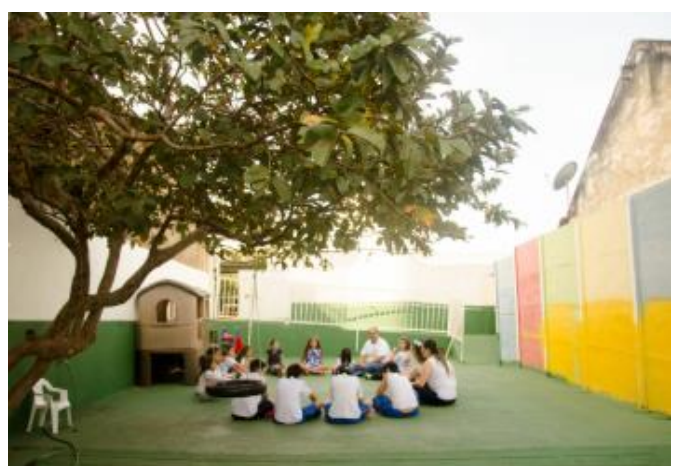

d)

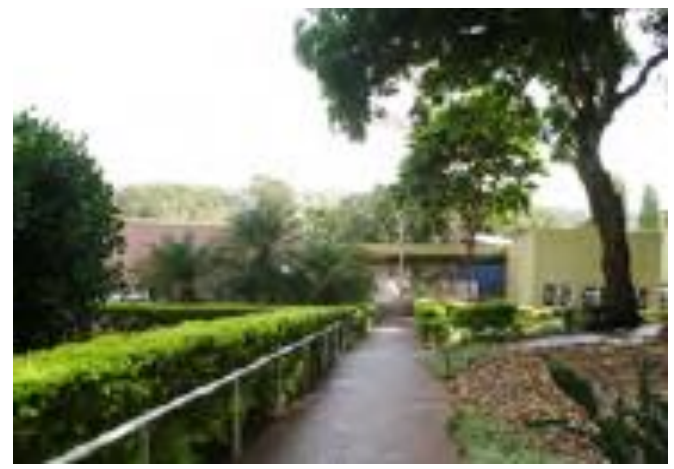

f)

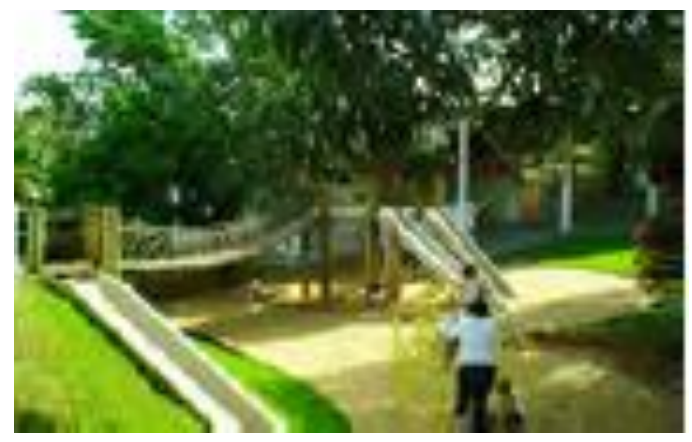

Fonte: ESCOLA DA CIDADE, 2018.

\section{CONSIDERAÇÕES FINAIS}

O presente trabalho não buscou esgotar, de forma alguma, o tema relativo ao papel profissional do arquiteto e urbanista enquanto formador dos espaços construídos úteis aos cidadãos, dentre eles, o espaço escolar, mas tão somente apresentar uma breve reflexão acerca da relação do projeto pedagógico e arquitetônico, firmada a partir da leitura das contribuições teóricas do campo arquitetônico e também pedagógico/educativo, tendo em vista que se complementam e representa um espaço social e de relevância para o crescimento e aprendizagem.

Verifica-se que que a inclusão entre o espaço escolar e seu modelo educativo representa um processo de transformação e mudança na mentalidade 
social, que se expressa mediante ao entendimento que o espaço percorre o processo de identificação e/ou construção de uma identidade. Ou seja, no espaço escolar, lugar onde a criança inicia-se sua participação com o mundo e com outras pessoas e, dessa forma, serve como referência às práticas sociais que nos formam enquanto indivíduos e também coletividade.

Na escola, portanto, o espaço torna-se identitário e cumpre seu papel enquanto educador ao ser significativo por quem o vivência, logo, entender a lógica do espaço educativo corresponde a refletir acerca da importância do ambiente físico. Nessa lógica, tem-se como exemplo trazido pela Maria Montessori, no qual propõe espaços e atividades que gerassem maior liberdade, atribuindo maior independência aos alunos de acordo com seu ritmo e a troca de experiencia entre aprendizes de diferentes idades.

O entendimento dos lugares identitários, aqui colocado no ambiente educacional, é entendido ao se pensar a materialização do lugar construído baseado no indivíduo, de suas relações afetivas e também da construção do modelo pedagógico, discutindo assim, simultaneamente a função social do espaço. Portanto, a concepção do espaço e a influência dos materiais poderá interagir com os alunos e educadores e criar um ambiente agradável e estimulante.

Dessa forma, conclui-se que há a necessidade de maior diálogo interdisciplinar dos profissionais de arquitetura e da pedagogia durante a elaboração de projetos. Isto é, visando atender as diversas condições para o ambiente escolar, assim como é abordado no exemplo trazido no texto sobre a Escola da Cidade. Percebe-se que a relação espaço-usuário representa um parâmetro essencial para a adequação do edifício escolar à proposta pedagógica adotada, uma vez que vai ser nesse ambiente que a criança irá se desenvolver.

\section{REFERÊNCIAS}

AZEVEDO, Giselle Arteiro Nielsen. Arquitetura escolar e educação: um modelo conceitual de abordagem integracionista, 2002, 208 f., Tese (Doutorado) Faculdade de Engenharia de Produção, Universidade Federal do Rio de Janeiro, Rio de Janeiro, 2002.

BROND, Rodrigo de Azambuja; MAZZARINO, Jane Márcia. O que fica, o que fui e o que fala: lugares identitários no ambiente urbano. Revista Ambiente \& Sociedade, v. 18, n. 4, p. 55-74, 2015. Disponível em: http://www.scielo.br/scielo.php?pid=S1414-

753X2015000400005\&script=sci_abstract\&tlng=pt. Acesso em 01 set., 2019.

COUTINHO, Evaldo. O espaço da arquitetura. São Paulo: Perspectiva, 1997.

DAYRELL, Juarez Tarcísio. A Educação do aluno trabalhador: uma abordagem alternativa. Educação em Revista, Belo Horizonte, n. 15, p. 21-29, 1992. 
DAYRELL, Juarez. A escola como espaço sócio-cultural. In: Juarez Dayrell. (Org.). Múltiplos Olhares sobre educação e cultura. Belo Horizonte: Editora da UFMG, p. 136-161, 1996.

ESCOLA DA CIDADE. Nosso espaço. 2018. Disponível em: http://www.escoladacidade.net.br/infrastructure/. Acesso em 04 set., 2019.

HERTZBERGER, Herman. Lições de Arquitetura. São Paulo: Martins Fontes, 1996.

LEFEBVRE, Henri. Social Space. In: The production of space. Trad. D. NicholsonSmith. Oxford: Basil Blackwell, 1991.

LIMA, Mayume Watanabe de Souza. A cidade e a criança. São Paulo: Nobel, 1989.

LORENTZ, Rafael de Conti. A arquitetura como ferramenta de construção da cidadania. In: II Congresso Internacional Uma Nova Pedagogia da Sociedade Futura: Protagonismo Responsável. Rio Grande do Sul: Faculdade Antônio Meneghetti, p. 99-110, 2016.

MELATTI, Sheila Pérsia do Prado Cardoso. A arquitetura escolar e a prática pedagógica, 2004, 120 f., Dissertação (Mestrado) - Centro de Ciências Tecnológicas, Universidade de Santa Catarina - UDESC, Santa Catarina, 2004.

NASCIMENTO, Mario Fernando Petrilli. Arquitetura para a educação: a contribuição do espaço para a formação do estudante, 2012,154 f., Dissertação (Mestrado) - Faculdade de Arquitetura e Urbanismo, Universidade de São Paulo, São Paulo, 2012.

NORBERG-SCHULZ, C. II Signifcato nell'a Architettura Ocidentale, 4. ed., Modadori Electa, 2003.

SANTOS, Elza Cristina. Dimensão lúdica e arquitetura: o exemplo de uma escola de educação infantil na cidade de Uberlândia, 2011, 363 f., Tese (Doutorado) Faculdade de Arquitetura e Urbanismo, Universidade de São Paulo, São Paulo, 2011.

SANTOS, Milton. A natureza do espaço: técnica e tempo, razão e emoção, 4.ed. São Paulo: Edusp, 2006. 


\title{
CONSELHOS MUNICIPAIS DE EDUCAÇÃO: Avanço das políticas públicas educacionais?
}

\author{
MESSIAS, Rosilene de Fátima Rocioli \\ Membro da comunidade
}

\section{INTRODUÇÃO}

A escolha pelo tema "Conselho Municipal da Educação" (doravante $\mathrm{CME}$ ) é decorrente dos estudos desta pesquisadora em uma das suas linhas de pesquisa: "Estado, Políticas Sociais e Serviço Social", sob a perspectiva do controle social como instrumento da sociedade civil. O mesmo instiga a pesquisadora a entender a função social da educação, especialmente quanto ao processo de gestão educacional, visto que busca compreender a realidade na sua totalidade para a concretização da práxis pedagógica transformadora, pois "o controle social é um direito do cidadão brasileiro, conquistado na Constituição Federal do Brasil (doravante CF) de 1988, ou seja, é um direito de participação da sociedade no acompanhamento e na verificação da gestão dos recursos federais empregados nas políticas públicas" (MARCELINO, 2013, p. 86).

Entende-se que os Conselhos Municipais de Educação podem desempenhar um papel relevante na busca de uma educação autônoma, crítica, possibilitando a transformação da realidade da classe trabalhadora brasileira e não somente a servidão a interesses econômicos e políticos.

Esses órgãos se revelam como espaços que podem promover a participação e o diálogo como forma de conscientização e emancipação da sociedade civil e da classe trabalhadora como forma de adquirir novos conhecimentos para fazer uma releitura da sua realidade, de modo a organizarse enquanto classe e conquistar seu espaço de cidadania. Esta pesquisa se propõe a pensar tal realidade educacional na pretensa ideia de que a educação não transforma a sociedade, mas, quiçá, consiga mudar as pessoas em um processo de transformação social.

A caminhada histórica da pesquisadora lhe permite enveredar por esse estudo educacional, entendendo que a sua atuação profissional enquanto assistente social e no exercício da docência revelam a possibilidade de contribuir com a sociedade por meio de reflexões para uma educação de qualidade que implica em uma participação comprometida nos conselhos locais, efetivamente engajada e cidadã, na qual todas as decisões e informações estejam ao alcance de todos.

Fatos históricos relatam que a presença dos Conselhos na área da educação é antiga no Brasil, pois a primeira tentativa deveu-se à criação de 
um conselho na estrutura da administração pública, em 1842, na Bahia. No entanto, o Conselho Geral de Instrução Pública foi criado apenas dois anos mais tarde (RIBEIRO, 2004, p. 40-41).

A ideia de Conselho Superior de Ensino se efetivou em 1911. Em seguida, outros se instalaram: o Conselho Nacional de ensino (1931); os Conselhos Estaduais de Educação (1961); os Conselhos Municipais de Educação (1971). Várias alterações em leis atualizaram a existência dos conselhos nessas esferas administrativas até os dias atuais. A realidade político-econômica do país, nas primeiras décadas do século $X X$, influenciaram intensamente no direcionamento e estabelecimento de uma política educacional elitista e excludente.

O Conselho Nacional de Educação (CNE) foi instituído pela Lei no 9.131, de 1995. É um órgão vinculado ao Ministério da Educação (MEC), criado para deliberar sobre políticas educacionais e questões pedagógicas. É uma instância nacional permanente de negociação federativa, no que diz respeito à função de pactuar aspectos de questão, financiamento e condições necessárias para a qualidade pedagógica proposta (BRASIL, 2009).

$\mathrm{E}$ ainda o CNE, por sua função normativa, deliberativa e consultiva e sua composição bipartida, deve pactuar-se com os Conselhos Estaduais da Educação e Conselhos Municipais de Educação, com a mesma função. No que se refere aos Conselhos Municipais de Educação, na contemporaneidade, caracterizam-se na concepção de que tais colegiados se vinculam à Secretaria Municipal de Educação e a interesses locais e comunitários, inserindo-se no efetivo cumprimento do direito à educação escolar de sua respectiva população.

Vale ressaltar que a educação contemporânea brasileira, ou ainda, o conhecimento que, muitas vezes, é resultado de um processo educacional, apresenta-se como uma mercadoria a serviço do "Capital" financeiro, pois nessa "nova" categoria chamada "sociedade do conhecimento" perde a sua qualidade, prevalecendo a infinidade de informações (MARCELINO, 2013, p. 10-11).

No final dos anos 1970 e início dos anos 1980, ocorreu a retomada dos movimentos sociais na busca pela construção de relações democráticas entre Estado e sociedade civil, assim como uma política de desenvolvimento econômico e social na perspectiva de reforma na organização e formulação de políticas sociais. Colocava-se em dúvida a estrutura política autoritária e a organização das políticas sociais instituídas no país, pois não respondiam às necessidades básicas da população. Foram propostas reformas para ampliar e redirecionar os gastos sociais e alterar os parâmetros de proteção social, segundo critérios justos de equidade e de uma reforma administrativa na máquina estatal responsável pelas políticas sociais a fim de corrigir as deformações existentes (DRAIBE, 1989). 
$\mathrm{Na}$ segunda metade da década de 1970, foram desenvolvidas várias experiências de gestão pública municipal inovadoras que trouxeram o componente de participação popular como elemento constitutivo da gestão pública, da qual muito do conteúdo político dessas experiências foram absorvidos pela CF.

A CF de 1988 definiu instrumentos de participação da sociedade civil no controle da gestão das políticas sociais, estabeleceu mecanismos de participação e implementação dessas políticas, apontou canais para o exercício da democracia participativa por meio de decisões direta como o plebiscito, referendo e de projetos de iniciativa popular. Sob essa perspectiva, a Carta Constitucional instituiu a criação de conselhos integrados por representantes dos diversos segmentos da sociedade civil para colaborar na implementação, execução e controle das políticas sociais.

\begin{abstract}
Os conselhos gestores de políticas públicas são espaços públicos de composição plural e paritária entre Estado e sociedade civil, de natureza deliberativa e consultiva, cuja função é formular e controlar a execução das políticas públicas setoriais. Os conselhos são o principal canal constitucional de participação popular encontrado na três instâncias do governo (federal, estadual e municipal) (MÓDULO DE COMPETÉNCIAS BÁSICAS, 2006, p. 70 apud, MARCELINO, 2013, p. 87).
\end{abstract}

Esses conselhos, que expressam uma das principais inovações democráticas no campo das políticas sociais, organizam-se em diferentes setores dessas políticas e devem assumir uma representatividade nas várias esferas governamentais. Possuem uma composição paritária entre representantes da sociedade civil e do governo e função deliberativa no que se refere à definição da política em cada setor e ao controle social sobre a sua execução (DOURADO, 2013).

$\mathrm{Na}$ contemporaneidade, são várias experiências de organização dos conselhos nas áreas da saúde, da criança e do adolescente, da educação, da assistência social e de outras. Caracterizam-se como novas formas de participação da sociedade civil na esfera pública como uma proposta de democratização das políticas sociais, porém, muitas vezes, na contraposição do modelo neoliberal legitimado pelos governos vigentes.

Nesse sentido, busca-se romper com a subordinação histórica da sociedade civil frente ao Estado por meio da construção de espaços de discussão e participação da sociedade civil na dimensão política da esfera pública, rumo à universalização dos direitos de cidadania.

A conquista de novos espaços de participação da sociedade civil se consolidou na construção de descentralização das ações, com maior responsabilidade dos municípios na formulação e na implantação de políticas sociais, na transferência de parcelas de poder do Estado para a sociedade civil organizada. Os conselhos paritários e deliberativos no âmbito das políticas 
públicas foram a estratégia privilegiada. Assim, são compostos por representantes de entidades da sociedade civil e representantes do governo que devem, em conjunto, participar do planejamento, das decisões e do controle de políticas sociais setoriais. Eles se mantêm como espaços públicos de discussão, decisão, acompanhamento e fiscalização de ações, programas e distribuição de recursos (GOHN, 2003, p. 100).

Por meio dos conselhos, objetiva-se propor alternativas de políticas públicas, criar espaços de debates entre governos e cidadãos, buscar mecanismos de negociação, conhecer a lógica burocrática estatal para socializar as ações e deliberações, ultrapassar interesses particulares e corporativistas em atendimento às demandas populares. Tem-se uma realidade dinâmica que busca a construção de esferas públicas autônomas e democráticas em relação às decisões políticas e, assim, rever as relações entre espaço institucional e práticas societárias (MORTORANO, 2003, p. 164165).

Hoje, há nos municípios brasileiros um grande número de conselhos implantados em diferentes setores, o que revela um novo modelo de participação da sociedade na gestão pública, oriundo das lutas sociais das últimas décadas, propondo uma redefinição das relações entre espaço institucional e práticas societárias, como forças antagônicas e conflitantes que se completam na busca de uma sociedade democrática.

É evidente que a garantia legal da criação e da implementação desses conselhos não garante a efetivação e a operacionalização de todos, logo, como a participação popular não pode tão pouco ser reduzida apenas ao espaço dos conselhos, sejam eles de assistência social, criança e adolescente, educação, saúde e outros, tal participação se apresenta como forma de participação política da sociedade civil organizada e que precisa ser devidamente acompanhada e avaliada. Com um acompanhamento sistemático das práticas dos conselhos, nas diferentes políticas sociais e nos diversos níveis governamentais, sinaliza-se para o perigo da burocratização, da rotina e da cooptação pelos órgãos públicos, centralizando as decisões nas mãos do poder governamental, neutralizando ou fragilizando a autonomia dos conselhos em suas ações e decisões. Como apontam Cisne e Sguihiro (2011, p. 47), os conselhos gestores podem ser um processo de luta das classes subalternas por democracia ou "eles representam a velha política disfarçada de democracia. A conscientização dos conselhos na condição de um espaço democrático exige organização política para além do seu espaço interior".

Tem-se na realidade dos muitos municípios brasileiros essa interferência dos órgãos governamentais, principalmente, no que diz respeito às decisões relativas ao orçamento, processo eleitoral dos conselheiros, escolha das presidências, entre outros. Apresenta-se como desafio, então, a formação dos conselheiros, sobretudo, da sociedade civil, nas competências 
políticas, econômicas, éticas, sociais, entre outras, para o exercício do seu papel com seriedade e compromisso social na gestão pública.

Referente à educação brasileira e aos Conselhos Municipais de Educação (objeto de investigação desta pesquisa), a realidade nacional é marcada por grandes evoluções, conquistas e rupturas, especialmente no que diz respeito aos autores que a construíram, dos jesuítas aos tempos atuais. Entretanto, evidencia-se uma educação ainda buscando seu rumo e prioridades para a população em geral.

No século XXI, a educação conquista importância no cenário da globalização, visto que a busca constante pela competitividade ampliou a demanda por conhecimentos e informação. Contemporaneamente, as políticas educacionais revelam o fracasso escolar e apontam que o seu enfrentamento poderá acontecer por meio das lutas constantes da sociedade civil junto ao poder público a fim de garantir o investimento na formação de profissionais e na qualidade do ensino (ANTUNES; PINTO, 2017, p. 108).

A educação é um direito social inalienável definido pela CF de 1988 para cada cidadão. Essa garantia resultou, ao longo dos anos, em vários instrumentos legais, especialmente a Lei de Diretrizes e Bases da Educação (1996), que reescreveu a educação nacional após a ditadura militar. Na concepção de Gramsci (2004), é necessária que haja uma educação/escola não mais "alienada e coisificada", mas emancipada e segue afirmando que é preciso

[...] de uma escola desinteressada. Uma escola na qual seja dada à criança a possibilidade de ter uma formação. De tornar-se homem. De adquirir aqueles critérios gerais que servem para 0 desenvolvimento do caráter. Em suma, uma escola humanista. Tal como entendiam os antigos, e mais recentemente, os homens do renascimento. Uma escola que hipoteque o futuro da criança, e não constrinja sua vontade, sua inteligência, sua consciência em formação, a mover-se por um caminho cuja meta seja prefixada (GRAMSCI, 2004, p. 75).

Merece destaque ainda a emenda constitucional no 59/2009, que trouxe marcos jurídicos avançados, como a obrigatoriedade do ensino para crianças de 4 a 17 anos, o Plano Nacional de Educação (Lei no 13.005, de 2014) e a inclusão, no texto constitucional, da expressão Sistema Nacional de Educação (SNE)14.

O Plano Nacional de Educação atual, com vigência de dez anos (2014-2024), expõe a real necessidade de recursos para sua execução e a exigência de ser referência aos diversos planos de governo. Da mesma forma, o Plano Estadual de Educação de São Paulo (Lei no 16.279/2016), ambos

\footnotetext{
${ }^{14}$ Sistema Nacional de Educação entendido aqui como um aperfeiçoamento na organização da educação nacional, sustentada por um pacto federativo construído de forma democrática e inscrito em um conjunto de leis nacionais, capazes de orientar cada sistema ou rede de ensino para que o direito constitucional inalienável seja garantido, com equidade, a cada cidadão brasileiro (DOURADO, 2015).
} 
serão estudos bibliográficos para a pesquisa, sendo que os planos municipais farão parte do estudo documental da mesma, os quais serão estudados mediante a efetivação de suas propostas de diretrizes e metas para a educação local, cujo recorte temporal será de 2018 a 2020 (trienal da pesquisadora).

Os Planos Municipais de Educação devem ser elaborados por meio da organização da sociedade civil e seus representantes do segmento da política educacional. Isso implica em ampla mobilização, articulação e participação dos conselheiros e, fóruns de debates, assembleias, conferências da sociedade civil, garantindo uma educação escolar em consonância com a realidade de seus educandos e que eleve, cultural e socialmente, a classe trabalhadora.

E, nesse sentido, Marcelino (2013, p. 93) entende que os Conselhos de Educação exerceriam sua autonomia para propor uma política educacional de acordo com a comunidade escolar e da realidade local. Podese afirmar que os CMEs desempenham um papel fundamental na organização do sistema de ensino no Brasil, assumindo o compromisso de normatizar o processo de ensino, acompanhar e avaliar as políticas educacionais na efetivação de direitos à população, como afirma Marcelino:

\begin{abstract}
A participação da sociedade civil e política, segundo Gramsci, utiliza instrumentos institucionais para se expressar, e caracteriza-se pela busca de consensos, construção de identidades, pela tentativa de controle da aplicação dos recursos públicos, pela interferência na elaboração de orçamentos, criação e efetivação de direitos e pelo enfrentamento de problemas cotidianos. No que se refere à Política Educacional, sua formulação deve ser de responsabilidade compartilhada entre as secretarias de educação, que efetivamente administram, executam e avaliam as ações, e os conselhos de educação. Neste contexto, cabe aos conselhos acompanhar e fazer o controle das ações do executivo, numa relação de cooperação, mas também de autonomia. É necessário, no entanto, que cadaa qual execute de fato suas funções pré-estabelecidas pela legislação, assim como seu compromisso coma qualidade de ensino, principal objetivo do CME (MARCELINO, 2013, p. 94-95).
\end{abstract}

Por fim, como destaque não mais relevante à pesquisa, mas fundamental ao que propõe este trabalho pela pesquisadora, a atuação do profissional de Serviço Social (assistente social), que tem se inserido com frequência nos conselhos em suas diferentes áreas. Entretanto, se por um lado, sua contribuição tem feito avançar a esfera pública no campo das políticas sociais, por outro, tem se apresentado à profissão a urgência da qualificação em seu aspecto teórico-metodológico, ético-político e técnicooperacional para atuar na elaboração dos planos nas esferas governamentais (SOUZA FILHO; GURGEL, 2016).

\title{
2. METODOLOGIA
}


A pesquisa se revela como um processo social e pela capacidade de questionamento e diálogo do pesquisador com a realidade investigada. Ela não determina resultados definitivos, inquestionáveis, mas sim uma realidade histórica e prática em permanente movimento.

Os procedimentos metodológicos da pesquisa contribuirão para se chegar à pesquisa anteriormente proposta. Eles se apresentam como "um conjunto de técnicas que permitem o desenvolvimento desta atividade nos diferentes movimentos do seu processo, nos auxiliam e possibilitam elaborar um conhecimento sobre a realidade" (PÁDUA, 2013, p. 32).

Esse estudo objetiva investigar $\mathrm{e}$ analisar os Conselhos Municipais de Educação (CME) na região geográfica de Ribeirão Preto/SP, enquanto órgão normativo, consultivo, deliberativo e fiscalizador das políticas municipais para a educação e no que se refere à participação dos diferentes segmentos da sociedade como mecanismo de gestão colegiada e democrática.

O Estado de São Paulo, entre 1989 e 2017, foi dividido, geograficamente, pelo IBGE, em quinze mesorregiões, as quais, por sua vez, foram subdivididas em 63 microrregiões. Em 2017, o IBGE extinguiu as microrregiões e mesorregiões, criando um novo quadro regional brasileiro com novas divisões geográficas denominadas, respectivamente, regiões geográficas imediatas e regiões geográficas intermediárias15, como revela 0 quadro a seguir:

Figura 1 - Mapa das regiões imediatas do estado de SP

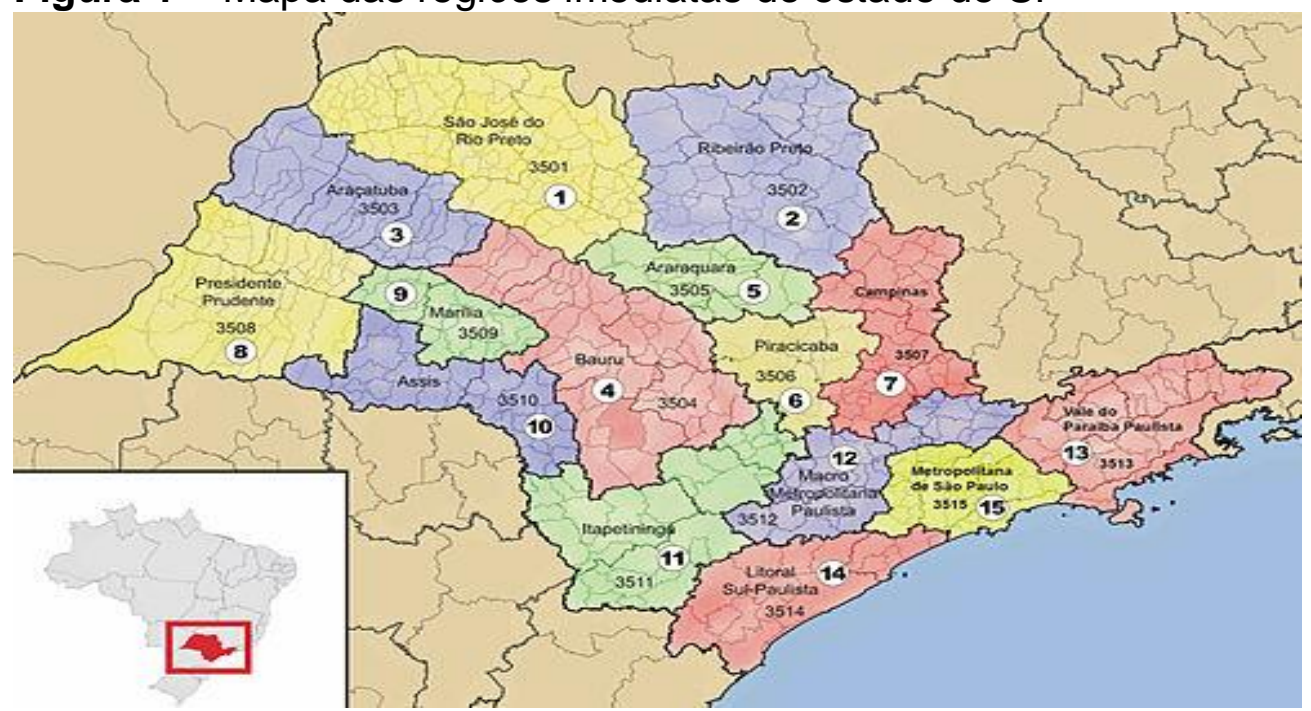

Fonte: IBGE (2017).

15 Região geográfica imediata: divisão criada pelo IBGE em 2017, em substituição às antigas microrregiões. Constitui um aglomerado de municípios conectados por meio de relações de dependência e deslocamento da população em busca de bens, prestação de serviços e trabalho. Região geográfica intermediária: divisão criada pelo IBGE em 2017, em substituição às antigas mesorregiões. Abrange um aglomerado de regiões geográficas imediatas, tendo como base uma ou mais metrópoles, capitais regionais e/ou centros urbanos representativos dentro do conjunto (IBGE, 2017). 
A pesquisa terá como cenário a região geográfica (intermediária) de Ribeirão Preto, do Estado de São Paulo, composta por sete microrregiões, sendo elas: Microrregião de Barretos, Microrregião de Batatais, Microrregião de Franca, Microrregião de Ituverava, Microrregião de Jaboticabal, Microrregião de Ribeirão Preto, Microrregião de São Joaquim da Barra.

A escolha pela região geográfica se justifica pelos seguintes critérios: (i) por se tratar da localização da Universidade Estadual Paulista "Faculdade de Ciências Humanas e Sociais", campus de Franca; (ii) por ser uma expressiva região econômica, cultural e educacional no cenário estadual paulista; (iii) e por ser uma grande área de atuação dos discentes egressos da UNESP.

A região geográfica de Ribeirão Preto é uma das quinze mesorregiões de São Paulo. É formada pela união de 66 municípios, agrupados em sete microrregiões. Conforme a Estimativa Populacional de 2017, sua população é de 2.613.217 habitantes, sendo a terceira maior região do estado de São Paulo. Seu PIB ultrapassou o valor adicional de $\mathrm{R} \$ 76$ bilhões, em 2014. Somente Ribeirão Preto, sua principal cidade e capital Regional Nível B, possui 682.302 habitantes, correspondendo a 36\% do PIB de toda a mesorregião (IBGE, 2017).

Figura 2 - Região geográfica de Ribeirão Preto

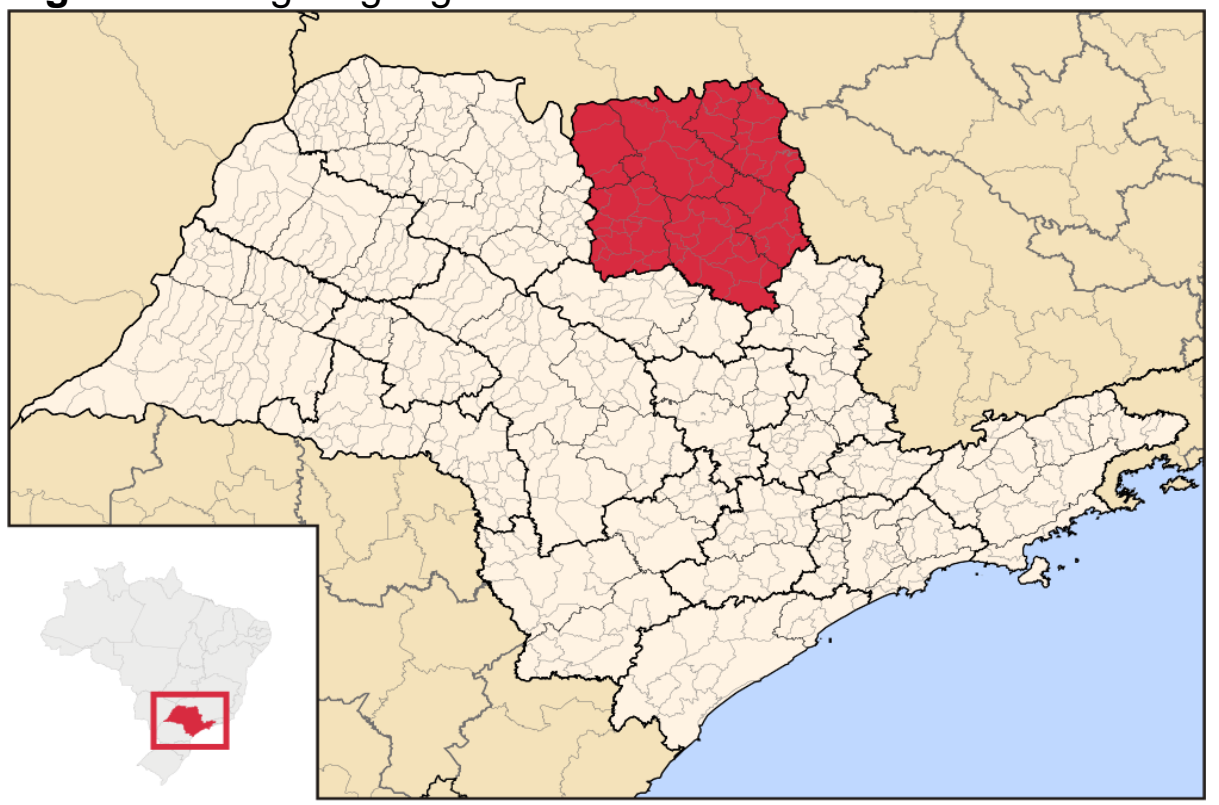

Fonte: IBGE (2017).

Esta pesquisa tem como objeto de estudo os Conselhos Municipais de Educação da região de Ribeirão Preto na função de formular e implementar as políticas de educação no município, assegurando a participação democrática da sociedade civil. E apresenta os seguintes 
questionamentos: Como esses conselhos têm se articulado para avançar com a política de educação no município, garantindo o amplo acesso, permanência e resultados qualitativos aos cidadãos no processo de ensino-aprendizagem? Os membros do conselho representam os segmentos dos quais fazem parte, ou há uma prática desconectada da realidade, burocrática e/ou cooptada pelo poder público local? E ainda, os planos municipais de educação foram elaborados com a ampla participação da sociedade e segmentos educacionais que atuam diretamente com os níveis (educação básica e superior)?

Por meio dessa concepção dinâmica da sociedade, é possível acreditar que os espaços de representação social na organização e gestão das políticas sociais devem ser ampliados, buscando a participação de novos e diferentes sujeitos sociais, de modo particular, os tradicionalmente excluídos do acesso às decisões do poder político.

Segundo a Lei de Diretrizes e Base da Educação Nacional (Lei no 9.394, de 1996), o Conselho Municipal de Educação é um órgão que compõe o sistema municipal de ensino, trazendo em sua natureza o princípio da participação e da representatividade da comunidade na gestão democrática, conforme 0 art. 9오 $\S 1^{\circ}$, "na estrutura educacional, haverá um Conselho Nacional de Educação, com funções normativas e de supervisão e atividade permanente, criado por lei” (BRASIL, 1996, on-line).

A defesa deste estudo está assentada na perspectiva de que os CMEs devem garantir a ampla participação da sociedade civil, representantes das famílias, alunos, professores, especialistas, profissionais da educação, associações de moradores, entidades e órgãos ligados à educação municipal e demais segmentos organizados da sociedade, eleitos ou indicados de forma democrática. E, nesse sentido, avançar com a Política de Educação, garantindo a ampliação, o acesso, a permanência e o processo de ensino e a aprendizagem de todos os alunos.

É importante observar que a composição do Conselho Municipal de Educação depende de cada realidade municipal, variando entre seis (6) e onze (11) conselheiros titulares, com seus respectivos suplentes. A Lei deve garantir a paridade do órgão, sendo a escolha de seus membros realizada de forma democrática.

A pesquisa será desenvolvida por meio de dois momentos que se integram: a pesquisa bibliográfica e a pesquisa documental16.

No que diz respeito à pesquisa bibliográfica, esta consistirá em uma revisão de literatura com estudiosos científicos da temática (tais como, Gramsci, Mascaro, Behring, Gohn, Saviani, Frigotto), permitindo uma

\footnotetext{
${ }^{16}$ Não será realizada a pesquisa de campo, pois, até o momento, deseja-se focar na análise e na interpretação dos muitos dados fornecidos pelas pesquisas bibliográfica e documental. Não obstante, a pesquisa estará aberta a complementações metodológicas se assim esta demandar.
} 
compreensão histórica da educação das políticas públicas de atendimento à educação básica no Brasil e do protagonismo do CME nas proposições de políticas públicas e, assim, percebendo as ações do Conselho no ensino escolar e ainda a gênese dos conselhos, sua contextualização e caracterização, bem como seu espaço de participação popular, muitas vezes, contraditório, no sentido de legitimar o que está determinado pelo poder vigente ou de contribuir para a qualidade de uma educação à classe trabalhadora proletária. Para isso o recorte histórico será realizado a partir do século XXI.

A pesquisa bibliográfica é desenvolvida a partir de material já elaborado, constituído principalmente de livros e artigos científicos. Embora em quase todos os estudos seja exigido algum tipo de trabalho desta natureza, há pesquisas desenvolvidas exclusivamente a partir de fontes bibliográficas. Parte dos estudos exploratórios podem ser definidos como pesquisas bibliográficas, assim como certo número de pesquisas desenvolvidas a partir da técnica de análise de conteúdo (GIL, 2012, p. 50).

A pesquisa documental será realizada com base na lei municipal que cria os Conselhos Municipais de Educação e no Documento Base dos Planos Municipais de Educação (PME) dos municípios que compõem a região geográfica de Ribeirão Preto, a saber: PME de Batatais (2015-2025); PME de Franca (2015-2025); PME de Ituverava (2015-2025); PME de Jaboticabal (2015-2025); PME de Ribeirão Preto (2014-2024); PME de São Joaquim de Barra (2014-2024).

Para a pesquisa documental, Gil (2012) entende como fontes não analisadas, mas também entende que corresponda a documentos que podem ser reelaborados segundo os objetivos da pesquisa.

\footnotetext{
A pesquisa documental assemelha-se muito à pesquisa bibliográfica. A única diferença entre ambas está na natureza das fontes. Enquanto a pesquisa bibliográfica se utiliza fundamentalmente das contribuições dos diversos autores sobre determinado assunto, a pesquisa documental vale-se de materiais que não receberam ainda um tratamento analítico, ou que ainda podem ser reelaborados de acordo com os objetivos da pesquisa. [...] Existem, de um lado, os documentos de primeira mão, que não receberam qualquer tratamento analítico, tias como: documentos oficiais, reportagens de jornal, cartas, contratos, diários, filmes, fotografias, gravações etc. De outro lado, existem os documentos de segunda mão, que de alguma forma já foram analisados, tais como: relatórios de pesquisa, relatórios de empresas, tabelas estatísticas etc. (GIL, 2012, p. 51).
}

A análise dos dados ocorrerá a partir de categorias que são históricas, que emanam da realidade e contribuem para a análise dos fenômenos, tendo como referência o material teórico e documental apreendido. As categorias teóricas da pesquisa serão: Conselho Municipal de Educação, Sociedade Civil, Democracia, Participação, Gestão Colegiada, Educação, Estado. 
O método dialético de análise, na perspectiva marxista, permitirá a compreensão crítica da realidade, em sua totalidade, de modo a permitir que o objeto seja estudado em seu contexto histórico, social e político.

Enfim, é evidente que no decorrer da pesquisa possa haver alterações nas formas de condução da mesma, porém, até o momento esses se apresentam como os principais eixos norteadores da pesquisa: (i) a existência de conselhos gestores, como canais democráticos de participação; (ii) e a conquista da efetivação dos direitos da população em geral à educação. Esses se colocam como desafios para a presente pesquisa.

\section{REFERÊNCIAS}

ANTUNES, R.; PINTO, G. A. A fábrica da educação: da especialização taylorista à flexibilização toyotista. São Paulo: Cortez, 2017. (Coleção da nossa época).

BEHRING, E. R. Política social no contexto da crise capitalista. In. Serviço social: direitos sociais e competências profissionais. Brasília/DF: CFESS/ABEPSS, 2009.

BRASIL. Divisão Territorial do Brasil em Regiões Geográficas Imediatas e Regiões Geográficas Intermediárias. Instituto Brasileiro de Geografia e Estatística. 2017.

BRASIL. Estimativas da população residente nos municípios brasileiros com data referência em 1 de julho de 2017. Instituto Brasileiro de Geografia e Estatística. 2017.

BRASIL. Conselho Municipal de Educação e suas articulações com as políticas públicas. Brasília: Ministério da Educação. Secretaria de Educação Básica, Universidade Federal de Santa Catarina, 2009.

BRASIL. Constituição Federal de 1988. Disponível em: $<$ www.planalto.gov.br/ccivil 03/constituicao/constituica067.htm>. Acesso: 05 jan. 2018.

BRASIL. Lei de Diretrizes e Base da Educação. Lei no 9394 de 20 de dezembro de 1996.1 Disponível em: $<$ http://www.planalto.gov.br/Ccivil 03/leis/L9394.htm>. Acesso: 05 jan. 2018.

CISNE M.; SUGUIHIRO, V. L. T. A produção do conhecimento em torno dos conselhos dos direitos da criança e do adolescente: uma análise de teses e dissertações. In: SOUZA FILHO, R.; SANTOS, B. R.; DURIGUETTO, M. L. (Org.). Conselhos dos direitos: desafios teóricos e práticos das experiências 
de democratização no campo da criança e do adolescente. Juiz de Fora, MG: UFJF, 2011.

DOURADO, L. S. Sistema nacional de educação, federalismo e os obstáculos ao direito à educação básica. Educação \& Sociedade, vol. 34:134, 2013, p 761-785.

DRAIBE, S. M. As políticas sociais brasileiras: diagnóstico e perspectivas. In: Para a década de 90: prioridades e perspectivas das políticas públicas, $\mathrm{n}$. 4, Brasília: IPEA/Ilan, 1989.

FREITAS, M. C.; BICCAS, M. S. História social da educação no Brasil (1926-1996). São Paulo: Cortez, 2009. (Biblioteca básica da história da educação brasileira v. 3).

GENTILI, P. (Org.). Política educacional, cidadania e conquistas democráticas. São Paulo: Fundação Perseu Abramo, 2013.

GIL, A. C. Métodos e técnicas de pesquisa social. 6. ed. São Paulo: Atlas, 2012.

GOHN, M. G. Conselhos gestores e participação sociopolítica. 2 ed. São Paulo: Cortez, 2003. (Coleção questões da nossa época).

GRAMSCI, A. Escritos políticos. Rio de Janeiro: Civilização Brasileira, 2004.

LIBÂNEO, J. C.; OLIVEIRA, J. F.; TOSCHI, M. S. Educação escolar: políticas, estrutura e organização. 10. ed. São Paulo: Cortez, 2012.

MARCELINO M. F. Conselho municipal de educação e ensino escola: limites, perspectivas e possibilidades. Campinas, SP: Mercado de letras, 2013. (Série Educação geral, educação superior e formação continuada do educador).

MARTORANO, L. C. Conselhos e democracia: em busca da participação e da sociabilização. São Paulo: Expressão Popular, 2011.

MASCARO, A. L. Estado e forma política. São Paulo: Boitempo, 2013.

MINAYO, M. C. S. (Org.). Pesquisa social: teoria, método e criatividade. Petrópolis/RJ: Vozes, 2016. (Série Manuais Acadêmicos).

NETTO, J. P. Introdução ao estudo do método de Marx. São Paulo: Expressão Popular, 2011.

PÁDUA, E. M. M. Metodologia da pesquisa: abordagem teórico-prática. 17. ed. São Paulo: Papirus, 2013.

PARO, V. H. (Org.) A teoria do valor em Marx e a educação. 2. ed. São Paulo: Cortez, 2013. 
PARO, V. H. Educação como exercício do poder: crítica ao senso comum em educação. 3 ed. São Paulo: Cortez, 2104. (Questões de nossa época v. 4).

PEREIRA, P. A. P. Estado, sociedade e esfera pública. In. Serviço social: direitos sociais e competências profissionais. Brasília/DF: CFESS/ABEPSS, 2009.

RIBEIRO, W. Municipalização: os conselhos municipais de educação. Rio de Janeiro: DP\&A, 2004.

SAVIANI, D. Trabalho e educação: fundamentos ontológicos e históricos. In Revista Brasileira de Educação. v. 12, n 34, jan./abr. 2007. p. 152-180.

SOUZA FILHO, R.; GURGEL, C. Gestão democrática e serviço social: princípios e propostas para a intervenção crítica. São Paulo: Cortez, 2016. (Biblioteca básica de serviço social; v. 5).

TONET, I. Educação, cidadania, emancipação humana. 2. ed. Maceió/Al: Edufal, 2013. 


\title{
EDUCAÇÃO E DIÁLOGOS INTERGERACIONAIS: O processo de envelhecimento e velhice para crianças e adolescentes
}

\author{
COSTA, Denise Gisele Silva \\ Doutora - UEMG \\ MATTAR, Jane Borges Lemos \\ Mestre - UEMG \\ QUEIROZ, Adriana de Souza Lima \\ Doutora - UEMG
}

\section{A QUESTÃO DO ENVELHECIMENTO NA CONTEMPORANEIDADE}

$\mathrm{Na}$ contemporaneidade $\mathrm{o}$ envelhecimento populacional se apresenta como uma nova realidade social, a partir de um avanço numérico sem precedentes altera de forma inédita a composição da pirâmide etária, representando a faixa com maior crescimento populacional nas últimas décadas. Segundo as Nações Unidas (2017), o mundo está vivenciando um processo de transição demográfica único e irreversível, assim, à medida que as taxas de fertilidade se reduzem, a proporção da população idosa acima dos 60 anos17 deverá duplicar entre 2007 e 2050, alcançando o número de 2 bilhões de idosos, para os mais idosos, acima dos 80 anos, a população deve duplicar, alcançando a inédita marca de quase 400 milhões.

Desta forma, o processo de envelhecimento e velhice se mostram como um dos grandes desafios do século XXI, sendo um fenômeno mundial, se concretizando de maneira gradativa nos países desenvolvidos e de forma acelerada nos países em desenvolvimento, principalmente nos últimos anos. Ressalta-se que por ter ocorrido de maneira mais lenta nos países centrais, a questão do envelhecimento já está inserida no debate econômico e político há décadas, na França por exemplo, foram necessários 116 anos para dobrar sua população acima dos 65 anos, saindo dos $7 \%$ para $14 \%$ no total, já no Brasil, segundo estimativas serão necessários apenas 21 anos para se ter o mesmo movimento.

Ao se tornar um marco na história da humanidade, o aumento populacional idoso pode ser associado há diversos fatores, como a queda da natalidade e mortalidade infantis, os avanços científicos e tecnológicos, condições apropriadas de alimentação, nutrição e acesso a bens e serviços,

\footnotetext{
${ }^{17}$ A ONU considera como idoso, pessoas com 60 anos e mais nos países em desenvolvimento e 65 e mais nos países desenvolvidos.
} 
proporcionando a melhora das condições gerais de vida das populações. No entanto, é necessário que se entenda o envelhecimento enquanto um fenômeno heterogêneo, multifacetado e complexo, tensionado constantemente por determinantes sociais que lhe imprimem características específicas de cada sociedade em determinado momento histórico, além de fatores extremamente relevantes como classe social, etnia, gênero, cultura, ideologia e atividades laborais, os quais permeiam o processo de envelhecimento e velhice.

Destaca-se que populações inteiras vivenciam um significativo aumento na expectativa de vida, de acordo com o Relatório de Envelhecimento e Saúde da Organização Mundial de Saúde (2015) uma criança nascida no Brasil em 2015 pode esperar viver cerca de 20 anos a mais que uma criança nascida há 50 anos, é inegável que este aumento seja uma conquista social, porém esta conquista não é linear, nem todas as populações têm tido as mesmas condições em relação à longevidade, em países africanos como Serra Leoa a expectativa de vida em 2017 não ultrapassava a 50 anos, não tendo se alterado significativamente até o momento. Este quadro é comum a muitos países da África subsaariana, como Angola que apresenta uma expectativa de vida de 52 anos, Lesoto de 53 anos, Nigéria de 54 anos, desta forma esta região se apresenta com as menores expectativas de vida do planeta, não sendo a longevidade uma realidade. Em seu lado oposto estão países desenvolvidos como Suíça com uma expectativa de vida que chega aos 83 anos, Espanha, Itália, Islândia, Israel, França entre outros apresentam expectativas de vida acima dos 82, 2 anos.

No Brasil, segundo IBGE (2018) a expectativa de vida do brasileiro chegou a 76 anos em 2017, atingindo um aumento de 30,5 anos se comparado a 1940, a unidade da federação que apresenta a maior expectativa de vida é o estado de Santa Catarina com 79,4 anos, embora a longevidade seja uma realidade, é necessário atentar-se para a brutal desigualdade existente no país, assim, analisar a velhice somente a partir do aspecto cronológico pode trazer sérios equívocos, ao não se considerar a heterogeneidade expressa nas dimensões biológica, cronológica, social, econômica, demográfica, cultural, psicológica, ideológica e política. O impacto destas dimensões é verificado ao se comparar um indivíduo proveniente de classes sociais abastadas, com um percurso profissional intelectual e um trabalhador rural do sertão nordestino ou um catador de recicláveis de grandes centros, mesmo que tenham a mesma idade cronológica dificilmente apresentariam a mesma idade biológica e social, o desgaste sofrido pelo trabalho manual, intensivo e insalubre durante toda a vida refletem diretamente na condição da velhice.

Desta forma, trabalhar a questão do processo de envelhecimento e velhice se faz extremamente relevante, uma vez que este é inerente a todos 
os seres humanos. Discutir sua heterogeneidade bem como estimular formas de enfrentamento às limitações ocasionadas por este processo, qualificam a sociedade a uma vida e uma velhice muito mais digna.

A longevidade humana é sem dúvida uma conquista significativa, no entanto, o distanciamento entre as gerações tem causado preconceitos que introjetados nos sujeitos sociais passam a desvalorizar socialmente a velhice, ora, assim a construção de um diálogo sobre as gerações passa a ser um desafio cotidiano, tanto para os profissionais que trabalham com o segmento idoso, quanto para a sociedade.

Destarte, propiciar o debate sobre uma sociedade cada vez mais envelhecida é tarefa importante para uma sociedade mais humana e menos preconceituosa, assim, ao estimular uma maior empatia entre as gerações e ao mesmo tempo sensibilizar as crianças e os adolescentes sobre a inerência do processo de envelhecimento à vida humana, contribui significativamente em sua formação humana e cidadã.

\section{A HETEROGENEIDADE DA VELHICE E SEUS ÊXITOS}

A velhice se mostra enquanto um fenômeno múltiplo, apresentando as dimensões cronológica, biológica, psicológica, cultural, econômica e social mostrando-se multifacetada, complexa e heterogênea. Assim, não se configura enquanto única a todos, pelo contrário, é vivenciada de diversas formas pelos sujeitos, se caracterizando de fato como o resultado da sua trajetória de vida. Para Beauvoir (1990, p. 15) a velhice tem uma dimensão existencial, modificando a relação do sujeito com o tempo e, portanto, sua relação com o mundo e com sua própria história, no entanto, o homem nunca vive em estado natural, assim na velhice, como em qualquer outra fase da vida, sua condição lhe é imposta pela sociedade a qual pertence.

Segundo a Organização Mundial de Saúde (OMS) a velhice é cronologicamente marcada a partir dos 60 anos de idade para os países em desenvolvimento, no entanto, ela se mostra multidimensional, havendo uma relação constante entre os aspectos cronológicos, biológicos, psicológicos, econômicos, sociais e culturais, assim, outros fatores devem ser considerados. Ainda segundo a OMS (2015, p. 10) no nível biológico o envelhecimento está associado ao acúmulo de danos moleculares e celulares, que passam a afetar as reservas fisiológicas dos indivíduos, porém essas mudanças não são lineares ou consistentes. Quanto ao processo de envelhecimento, estudos afirmam que biologicamente, ele se inicia por volta dos 30 anos, quando o organismo inicia esse processo de danos moleculares e celulares, encetando uma perda constante e gradativa das reservas fisiológicas. 
Ao mencionar o desafio de se estudar a velhice, Beauvoir (1990, p. 109) relata a dificuldade de encontrar documentos sobre os velhos, pois, em sua maioria estes, são incorporados ao conjunto do adultos, e quando retratada, a velhice se mostra variável de acordo com os tempos e lugares, se tornando incerta, confusa e contraditória, tendo a palavra velhice dois sentidos diferentes: "É uma categoria social mais ou menos valorizada segundo as circunstâncias. É para cada indivíduo, um destino singular- o seu próprio" (BEAUVOIR, 1990, p. 109).

A temática processo de envelhecimento e velhice será compreendida enquanto uma construção social, ao se afirmar que a velhice e o envelhecimento são heterogêneos, não são o mesmo e não se manifestam da mesma forma a todos, passamos a entender que o idoso é o reflexo deste conjunto de determinantes, é o resultado de um processo, e não algo novo, desconectado daquilo que o indivíduo foi e viveu em toda a sua vida. Dentro desta perspectiva histórica e de totalidade podemos compreender o idoso como uma invenção social, fruto de uma sociedade que determina a sua valorização ou seu contrário em aspectos múltiplos e opostos.

\begin{abstract}
Por isso mesmo, somos levados a concluir que a velhice e o envelhecimento são socialmente construídos. A partir do referencial biológico, fatores não biológicos marcam profundamente o ritmo, a natureza, a estrutura, funções e significações da velhice, a ponto de perguntarmos se a velhice não é antes de tudo uma entidade criada em um processo social em que alguns atribuem a outros pesos e medidas. (MAGALHÃES, 1989, p. 20)
\end{abstract}

O segmento idoso com um percurso marcado por lutas, alcança visibilidade e começa a ter seus direitos sociais atendidos, no entanto, há de se esclarecer que se trata de velhices, em seu plural, muitas vezes antagônicas, dentro de uma heterogeneidade marcante, assim é possível que uma parcela destes velhos, que tiveram uma trajetória de vida digna, dentro dos padrões de pleno emprego e de acesso a seguridade social se aposentam ainda com saúde, com possibilidades de ter uma velhice também digna, a estes, o estereótipo de inválidos, doentes e decadentes não pode ser aplicado. Em seu contrário, tem-se os trabalhadores que não conseguiram ter uma vida laboral decente e em sua velhice permanecem vulneráveis às contradições do sistema capitalista, com o aprofundamento da desigualdade.

Seguindo as tendências impostas pelos organismos internacionais e ao mesmo tempo, enquanto reflexo das lutas dos movimentos sociais dos velhos trabalhadores (inclusive com a promulgação da CF), tem-se em 1994 a regulamentação de uma política direcionada ao segmento idoso, a criação da Lei n. 8842/94 denominada Política Nacional do Idoso (PNI), que dispõe sobre os direitos sociais desta população, garantindo autonomia, integração e participação efetiva como instrumento de cidadania, uma conquista em termos legais. Consistindo em assegurar os direitos sociais da população idosa, 
partindo do princípio fundamental de que "o idoso é um sujeito de direitos e deve ser atendido de maneira diferenciada em cada uma das suas necessidades: físicas, sociais, econômicas e políticas". (CAMARANO, 2004, p. 269), tendo como premissa a promoção da qualidade de vida.

A PNI apresenta como diretrizes norteadoras o incentivo e a viabilização de formas alternativas de cooperação intergeracional; a necessária participação dos idosos através de suas representações na formulação, implementação e avaliação de políticas, planos e programas; a prioridade de seu atendimento em condição de vulnerabilidade por suas famílias em detrimento do atendimento asilar; a descentralização político-administrativa; a capacitação de recursos humanos nas áreas da geriatria e gerontologia; a prioridade do atendimento em órgãos públicos e privados prestadores de serviços; e o fomento das discussões e desenvolvimento de estudos referentes à questão do envelhecimento.

$\mathrm{Na}$ esteira das conquistas do segmento idoso, em 2003, é promulgado o Estatuto do Idoso (Lei no 10.741/2003), visando reforçar as diretrizes contidas na $\mathrm{PNI}$ e formando as bases das políticas públicas voltadas ao segmento, apresentando como direitos fundamentais da pessoa idosa o direito à vida, à saúde, à alimentação, à educação, à cultura, ao esporte, lazer e cultura, ao trabalho, à cidadania, à liberdade, à dignidade, ao respeito e a convivência familiar e comunitária, abarcando todos os aspectos da vida social do velho trabalhador. Desta forma, o Estatuto dispõe de princípios e intenções em relação a população idosa e traz para a sociedade um conjunto de diretrizes e regulações a serem observadas tanto pelas instituições/órgãos sociais quanto pela população em geral.

Segundo Alcântara (2016, p. 366), o Estatuto do Idoso criou um sistema de garantia de direitos, que apesar dos problemas, tem buscado a efetivação dos direitos sociais dos idosos brasileiros.

O sistema de garantias previsto no Estatuto é composto pelas seguintes instituições/órgãos: Conselhos do Idoso; Sistema Único de Saúde (SUS); Sistema Único de Assistência Social (SUAS); Vigilância em Saúde; Poder Judiciário; Defensoria Pública; Ministério Público; e Polícia Civil. Acredito que a eficiência desse sistema de garantias é uma das possibilidades para a efetividade dos direitos da pessoa idosa. (ALCÂNTARA, 2016, p. 366)

O Estatuto propõe mecanismos necessários à regulamentação dos direitos da população idosa, é um dispositivo formal que garante os direitos elementares da existência, os direitos fundamentais inerentes à pessoa humana, independente de sua condição econômica, de produção ou consumo, ou seja, do "valor de uso" que apresente para o mercado, desta forma tem-se a perspectiva do idoso enquanto sujeito de direitos, mesmo quando se configurando enquanto "não-rentável" para o capital. (TEIXEIRA, 2008, p. 289). 


\title{
4. A INTERGERACIONALIDADE E SEUS DESAFIOS
}

O fator geração se soma a muitos outros determinantes do comportamento social, como a classe, o gênero e a etnia, assim, padrões sociais são preestabelecidos de acordo com a faixa etária, assim é comum ouvir em nosso cotidiano "Isso é coisa de velho" ou "Você parece criança", tais frases trazem consigo estereótipos comportamentais relacionados diretamente a idade cronológica que se tem. Há de se considerar que além da dimensão biológica, as gerações são historicamente construídas, de acordo com seu tempo histórico, assim, a construção social das gerações se concretiza por meio de valores morais e expectativas de conduta para cada geração, cada fase da vida.

Desta forma passa-se a ter a fragmentação do tempo de vida ou o surgimento das categorias etárias que tem seu início na modernidade, com o advento da industrialização e de uma nova organização social - o capitalismo, pois nas sociedades pré-industriais não havia a separação nítida entre as diversas fases da vida, tampouco as especializações funcionais de cada idade. Foi a partir do século XIX que passam a surgir gradativamente as diferenciações entre as idades, os espaços e hábitos de cada faixa etária e as funções socialmente delimitadas a cada uma delas. Assim tem-se o início da fragmentação do curso de vida em estágios mais formais, em transições mais rígidas, em funções determinadas para cada estágio da vida.

\begin{abstract}
Desse modo, o reconhecimento da velhice como uma etapa única é parte tanto de um processo histórico mais amplo - que envolve a emergência de novos estágios da vida como a infância e a adolescência - quanto de uma tendência contínua em direção à segregação das idades na família e no espaço social. (SILVA, 2008, p.157)
\end{abstract}

Com a contribuição dos estudos do historiador Phillipe Àries (1978) acerca do surgimento da categoria infância foi possível vislumbrar outras faixas etárias como a adulta e a velhice, e os fatores marcantes de cada parte da vida humana, agora desmembrada em vários rituais, funções, exigências, ocupações, espaços e significados. O "eu" se torna múltiplos "eus" de acordo com a idade cronológica.

A partir do século XX já se pôde observar dentro dos grupos etários uma homogeneização de cada fase da vida, com uma demarcação mais ou menos precisa entre as diferentes idades bem como a institucionalização de ritos de passagem como o ingresso na escola, na universidade, no mercado de trabalho ou na aposentadoria. Desta forma a identidade do sujeito moderno passa a ser forjada no ato de "habitar" cada uma das etapas da vida - infância, adolescência, juventude, idade adulta e velhice. 
Para Debert 2012 (apud KOHLI, MEYER 1986) há um processo de individualização que é próprio da modernidade, onde a "cronologização da vida" institucionaliza o curso da vida humana, envolvendo praticamente todas as dimensões do mundo familiar e do trabalho, estando presente na organização do sistema produtivo, nas instituições educativas, no mercado de consumo e nas políticas públicas, que cada vez mais tem como alvo grupos etários específicos.

Assim, uma organização social em que a idade cronológica era irrelevante, acabou sendo suplantada por outra, onde a idade é fundamental para a organização social. Explicitando as possíveis razões, atribuem às mudanças estruturais da economia, na transição da economia doméstica para economia de mercado e inversamente enfatiza-se o Estado Moderno, que por excelência seria a instituição que orienta o curso de vida, "[...] regulamentando todas as suas etapas, desde o momento do nascimento até a morte, passando pelo sistema complexo de etapas de escolarização, entrada no mercado de trabalho e aposentadoria" (DEBERT, 2012, p.56 apud KOHLI, MEYER, 1986).

Debert (2012 apud GIDDENS 1992) afirma que na modernidade a própria ideia do ciclo de vida perde sentido, considerando que a vida pessoal e troca entre gerações se quebram. Nas sociedades pré-modernas a tradição e a continuidade estavam estreitamente vinculadas com as gerações, havia rituais que marcavam estas trocas.

$\mathrm{Na}$ modernidade as fases de transição de uma etapa a outra tendem a ser interpretadas pelo indivíduo como uma crise de identidade, não havendo uma linearidade no curso de vida, mas sim sendo demarcado por constantes crises.

Em seu estudo sobre a relação entre infância e velhice Gusmão (2003) indica que tanto as crianças quanto os velhos são alvos de procedimentos educativos que visam à homogeneização do diverso, pois ambos de certa forma não estão inteiramente subsumidos aos ditames da ordem social objetiva, podendo em algum momento escapar da opressão causada pelo capital.

Não é sem razão que, nos tempos de hoje, similar ao que aconteceu e acontece com a criança, a chamada 'terceira idade' constitui uma nova etapa educativa no interior das sociedades modernas. (GUSMÃO, 2003, p. 25 apud GIDDENS, 1995).

Assim a criança e o velho são destituídos de sua autonomia e independência, para determinar-se socialmente. "Com isso descobre-se que os problemas desse outro - criança ou velho - está em nós e na imagem que construímos de nós mesmos como padrão do que é ser, de modo pleno e completo" (GUSMÃO 2003, p. 27).

A autora afirma que crianças e velhos são um patrimônio cultural e social extremamente rico, e evidenciam a estratificação e a permanente 
classificação de coisas e de pessoas determinadas pela sociedade moderna. Ressalta também que o adulto produtivo é considerado por seus atributos um ser superior, modelo a ser seguido e respeitado.

[...] igualar-se aos deuses imortais, é esse o desejo das culturas como a nossa, que banalizam ou tentam fechar os olhos à fatalidade da morte, que acumulam riquezas comercializando acintosamente o mito da eterna juventude, fazendo crer na capacidade humana de tudo reparar, de tudo -controlar, de eliminação total do acaso. É difícil em nosso mundo aceitar os limites do ser humano de ser apenas humano. (PERROTI, 1990, p.42 apud GUSMÃO, 2003, p. 27)

Destarte, as gerações são historicamente construídas, desconstruídas e reconstruídas, de modo que as relações entre elas sejam constantemente refeitas, isto é, a maneira como as relações geracionais são estabelecidas determinam novos comportamentos intergeracionais. Esse movimento dialético de reconstrução permanente ocorre no cotidiano das relações, mas o que se presencia, atualmente, é o distanciamento, as gerações vivem segmentadas em espaços restritos. Ambientes exclusivos para uma parcela geracional são cada vez mais comuns, pois neles esperam-se determinados comportamentos e atitudes, o que acabam por ser considerados naturais e, até mesmo, pedagógicos, morais e adequados. Desta forma crianças e adolescentes possuem seus espaços distantes dos espaços dos idosos, no entanto o convívio intergeracional se mostra necessário, em especial em uma sociedade que envelhece rapidamente

Neste contexto a intergeracionalidade se mostra extremamente relevante, uma vez que as trocas geracionais permitem uma maior socialização e potencializam a empatia entre gerações distintas. Debater o processo de envelhecimento e velhice junto às crianças e adolescentes lhes permite o entendimento do envelhecer enquanto um processo natural inerente a todos os seres vivos, propiciando um novo olhar sobre o "outro" o "diferente" de si mesmo.

Desta forma estratégias de interação baseadas nas vivências e oralidade de cada grupo permitem o entendimento do outro, ao mesmo tempo que coloca a todos sob o julga do tempo, do qual ninguém consegue escapar, ou seja, enquanto vivos... envelhecemos.

\section{CONSIDERAÇÕES FINAIS}

Diante do exposto, considerando-se o inédito processo de envelhecimento da população mundial e em especial da população brasileira, faz-se urgente abordar a questão do envelhecimento e velhice nos processos educativos voltados à crianças e adolescentes, propiciando debates profícuos que vislumbrem formas de estimular $o$ enfrentamento às limitações $e$ 
transformações desencadeadas por este processo, qualificando a sociedade a um novo patamar de empatia, solidariedade e humanização, em especial em tempos tão obscuros quanto os da atualidade, tempos em que a intolerância e o desrespeito ao outro apresenta tons de normalidade.

Destarte a longevidade humana é sem dúvida uma conquista significativa, no entanto, o distanciamento entre as gerações tem causado preconceitos que introjetados nos sujeitos sociais passam a desvalorizar socialmente a velhice, ora, assim a construção de um diálogo sobre as gerações passa a ser um desafio cotidiano, tanto para os profissionais que trabalham com o segmento idoso, quanto para a sociedade como um todo. Assim, propiciar o debate junto às crianças e adolescentes sobre uma sociedade cada vez mais envelhecida é tarefa importante que reflete em atitudes e valores mais empáticos e menos preconceituosos, consolidando a formação de cidadãos.

\section{REFERÊNCIAS}

ALCÂNTARA, A.O. Da Política Nacional do Idoso ao Estatuto do Idoso: a difícil construção de um sistema de garantias de direitos da pessoa idosa. In:

ALCÂNTARA, A. O.; CAMARANO, A.A; GIACOMIN, K.C, Política Nacional do Idoso: velhas e novas questões. Rio de Janeiro: IPEA, 2016

ARIÈS, Philippe. História social da criança e da família. Rio de Janeiro: Zahar. 1978

BEAUVOIR, S. A velhice. Rio de Janeiro: Nova Fronteira, 1990.

BOSI, E. Memória e sociedade: lembranças de velhos. São Paulo: Companhia das Letras, 1994.

BRASIL. Estatuto do Idoso. Lei n. 10741, de 1 de outubro de 2003, e legislação correlata. Brasília, DF: Centro de Documentação e Informação: Ed. Câmara, 2008. (Legislação, n.14)

. Lei n. 8.842, de 04 de janeiro de 1994. Dispõe sobre a Política Nacional do Idoso. Brasília, 1994. Disponível em < http://www.planalto.gov.br/ccivil 03/LEIS/L8842.htm> Acesso em 26 Jan. 2019.

CAMARANO, A.A. Os Novos Idosos Brasileiros: Muito além dos 60 ? Rio de Janeiro: IPEA, 2004.

COMISSÃO ECONÔMICA PARA A AMÉRICA LATINA E O CARIBE. Conferência Regional Intergovernamental sobre Envelhecimento e Direitos dos Idosos na América Latina e no Caribe. 2019. Disponível em https://www.cepal.org/pt-br/orgaos-subsidiarios/conferencia-regional- 
intergovernamental-envelhecimento-direitos-idosos-america > Acesso em 24 Jan 2019.

DEBERT, G. G. A reinvenção da velhice: socialização e processos de reprivatização do envelhecimento. São Paulo: Universidade de São Paulo, FAPESP, 2012.

FERRIGNO, José Carlos. Coeducação entre Gerações. 2ª ed. São Paulo:

Edições

SESC SP, 2010.

GUSMÃO, N. M. M. (Org.). Infância e velhice: pesquisa de ideias. Introdução. Campinas: Alínea, 2003.

IBGE. Em 2017 a expectativa de vida era de 76 anos. Rio de Janeiro, 2018a. Disponível em < https://agenciadenoticias.ibge.gov.br/agencia-sala-deimprensa/2013-agencia-de-noticias/releases/23200-em-2017-expectativa-devida-era-de-76-anos >. Acesso em 09 jan. 2018.

. Projeção da população. Rio de Janeiro: 2008. Disponível em < https://ww2.ibge.gov.br/home/estatistica/populacao/projecao da populacao/20 08/piramide/piramide.shtm> Acesso em 20 Jan 2019.

KURZ, R. A expropriação do tempo. 1999. Disponível em:

$<$ www.race.nuca.ie.ufrj.br/journal/k/kurz2.doc $>$ acesso em 09 jun.2016

MAGALHÃES, D.N. A invenção social da velhice. Rio de Janeiro: Ed. Papagaio, 1989.

NERI, A.L. As políticas de atendimento aos direitos da pessoa idosa expressas no Estatuto do Idoso. A terceira idade. (SESC), São Paulo. V. 16, n 34, p 7-24, out. 2005.

. Feminização da velhice. In: NERI, A.L. (Org). Idosos no Brasil: vivências, desafios e expectativas na terceira idade. São Paulo: Editora Fundação Perseu Abramo, 2007. 


\title{
ESTUDANTES DO ENSINO MÉDIO: Perspectivas e relação com a universidade
}

\author{
BATISTA, Evelyn Riola \\ Graduanda em História - UNESP \\ Evelyn.riola@gmail.com \\ FONSECA, Genaro Alvarenga \\ Doutor em Psicologia e Educação Escolar - UNESP \\ Ga.fonseca@unesp.br
}

\section{INTRODUÇÃO}

A educação brasileira, é regulamentada pela Lei de Diretrizes e Bases - LDB, Lei ํo 9.394/96, que divide a educação entre ensino básico e ensino superior, onde o primeiro é composto pela educação infantil, ensino fundamental e ensino médio, tendo caráter obrigatório e gratuito a partir da emenda constitucional no59/2009. O ensino superior, por sua vez, é considerado opcional, sendo escolha individual ingressar e permanecer nele, mas será que este nível de ensino tem se apresentado como possibilidade a todos os jovens do país?

Ambos os níveis de escolaridade apresentados são oferecidos pelo Estado e também por instituições privadas. Durante os anos do ciclo básico as escolas públicas são frequentadas, majoritariamente, por alunos de classes sociais mais baixas, e as escolas particulares são destinadas, em sua maioria, aos filhos das famílias com maior poder aquisitivo, no entanto, quando se chega ao ensino superior, a presença de estudantes oriundos da rede particular é maior nas universidades públicas, e grande parte dos egressos da rede pública não continuam a estudar, ou ingressam na rede privada de ensino superior. Por que há tal inversão se tais estudantes têm condições de pagar mensalidades particulares? Por que os estudantes mais humildes ocupam poucos lugares nas universidades, em especial as públicas? Será falta de interesse ou dificuldade de acesso? Será que sabem de seu direito ao ensino superior gratuito e de qualidade?

O ensino médio é a etapa final do ensino básico, onde o jovem se vê encerrando um ciclo e tendo de iniciar outro, com novos direcionamentos e responsabilidades. Tendo em vista esse momento de escolhas, o que será que eles têm pensado sobre seu futuro? Quais seus desejos? Quais possibilidades estão postas diante deles? 
A partir das questões levantadas, colocadas em análise conjunta à uma perspectiva inserida no contexto uma universidade pública (UNESPCampus de Franca), o presente trabalho procura iniciar uma reflexão sobre as oportunidades que são apresentadas à maioria dos jovens brasileiros, que em sua fase final do ensino básico estão matriculados na rede pública de ensino, buscando levantar essas questões dentro do contexto acadêmico, para fomentar a discussão de como a instituição universitária tem se relacionado com os estudantes da educação básica.

Para a construção deste artigo, houve uma pesquisa de caráter teórico com trabalhos produzidos no país, e também a análise de alguns dados referentes à região de Franca/SP e à Universidade Estadual Paulista "Júlio de Mesquita Filho", no seu campus localizado na cidade citada. É válido pontuar que há o entendimento de que existem diferentes realidades no Brasil, mas que de acordo com trabalhos produzidos em todo o território, pode-se perceber certo padrão no assunto estudado, e espera-se que a partir do caso local iniciese uma reflexão mais ampla sobre o tema. É importante ressaltar que o presente trabalho procura se apresentar como fomentador de discussão e que a problemática em questão pede por uma pesquisa mais aprofundada, por isso se mostrará mais introdutório do que conclusivo.

\section{DESENVOLVIMENTO}

Nesse primeiro momento, chama-se a atenção para 0 adolescente/jovem que se encontra nos anos finais do ensino básico. Para ter uma breve noção do que esse momento representa é interessante compreender os indivíduos como seres em constante modificação, mas que na fase da adolescência, devido ao modo como a sociedade está organizada, são condicionados a fazerem planos e escolhas determinantes para suas vidas. Nesta linha de raciocínio Marcelino, Catão e Lima (2009) entendem a adolescência e o projeto de vida como construção psico-sociohistórica, ou seja, defendem que todo fato só pode ser compreendido quando analisado inserido na totalidade de onde foi produzido, e que o adolescente é "um ser ativo, social e histórico, que produz histórica e coletivamente a si próprio e à sociedade e é por ela produzido" (MARCELINO; CATÃO; LIMA, 2009, p.546). No tocante aos projetos de vida, segundo as autoras, são planos criados de forma dialética entre a subjetividade e objetividade, que objetivam as transformações futuras de suas vidas, a partir da reflexão acerca das próprias vivencias, concluindo se há ou não a possibilidade de acontecer a superação de certas realidades futuramente. Ou seja, o adolescente e suas perspectivas de futuro estão intimamente ligados às condições sociais que permeiam sua existência, nesse sentido, o ambiente escolar e as relações que se dão dentro dele, além do quadro familiar e social influenciam diretamente nos anseios desse jovem em seus momentos decisivos. 
Para Oliveira e Saldanha (2010) uma boa síntese para definir "perspectivas de futuro/projetos de vida" seria:

\begin{abstract}
"A forma como os indivíduos percebem o seu futuro e os objetivos de vida que se propõem a atingir, ou, ainda, como um construto voltado para o planejamento ou esperança de concretizar algo, posteriormente, que considera a influência de outras variáveis teóricas, como a maturidade profissional e motivação dos indivíduos, por exemplo, e aquelas de natureza socioeconômica, como renda, contato com outras culturas, dentre outras." (OLIVEIRA; SALDANHA, 2010)
\end{abstract}

Oliveira e Saldanha (2010) realizaram uma pesquisa com 296 adolescentes, que em sua maioria tinham de 16 a 18 anos, sendo $54,1 \%$ estudantes de escolas privadas e $45,9 \%$ de escolas públicas, onde questionaram a maneira que os jovens imaginavam como seriam seus futuros, e perceberam que a maioria dos jovens tem esperanças positivas, mas dos que imaginam seu futuro de forma negativa, a maior parte está matriculada no ensino público. As pesquisas apontaram também as diferenças de renda familiar desses estudantes, onde o grupo de alunos da escola pública, apresentam predominantemente renda inferior a $R \$ 500,00$, e os do ensino privado, superior a $R \$ 2.000,00$. Quanto aos objetivos de vida, há aproximação entre os anseios de ambos, que estão relacionados principalmente ao trabalho, estudos e família/relações afetivas. Os entrevistados, majoritariamente encaram o ensino superior como importante, no entanto, a respeito de qual carreira querem seguir os estudantes de escola pública se mostram mais indecisos. Segundo as autoras e suas referências, isso pode acontecer porque os alunos da rede privada tem mais esperanças de ingressar no ensino superior pois enxergam que esse é praticamente o único meio de se profissionalizar e de ingressar no mercado de trabalho, enquanto os da rede pública não tem certeza sobre seus futuros, e tem menos expectativas de ingressar em uma universidade, nesse sentido Oliveira e Saldanha citam 0 estudo de Locatelli e cols. (2007) que diz que a definição da identidade vocacional se dá ao fim do ensino básico, principalmente porque considera-se a chance de ingressar em seguida no ensino superior, portanto a falta de expectativa de entrar em uma faculdade colabora para a indecisão do adolescente.

Outro estudo a respeito do tema foi realizado por Cabral (2017), que entrevistou 50 alunos da rede pública da periferia da cidade de São Paulo, com uma faixa-etária predominante de 17 e 18 anos. O pesquisador obteve como resultado que a maior parte dos estudantes vê o ensino médio como importante para se inserirem no mercado de trabalho, além de seu caráter formador e espaço de interação social. Esses alunos enxergam a educação como forma de ascensão social, principalmente, pois dão mais possibilidade de emprego, em sua maioria estão interessados em continuar seus estudos futuramente, no entanto, poucos consideram que a continuidade se dê em 
universidades públicas, alegando que a qualidade de ensino que recebem não é suficiente para competir com os alunos da rede privada e dos cursinhos de alta qualidade, enxergando-se como incapazes, ou construindo sua vida a partir da lógica de trabalhar para pagar um cursinho ou a faculdade, para continuar trabalhando e melhorar as condições de vida, como apresentado na fala da estudante de 17 anos do período noturno, Diana: "Quero fazer uma faculdade particular, não tenho chances de passar na USP" ou ainda no discurso da estudante Aline, também de 17, mas do período matutino: "(Espero) não passam em qualquer vestibular ou Enem. (preciso trabalhar para) conseguir coisas boas. Tenho que ser organizada para pagar cursinho para reforçar meu estudo" (CABRAL, 2017, p. 67).

Ainda a respeito do trabalho de Cabral (2017), a maioria desses jovens diz receber apoio em casa para concluir o ensino médio, associando o período de estadia na escola como distancia da violência da rua, ou ainda porque o pensamento da escola para ascender socialmente é bastante difundido nas camadas sociais mais pobres, mas reclamam da falta de incentivo de alguns professores e da escola que não acreditam em suas potencialidades.

Oliveira, Pinto e Souza (2003) também realizaram pesquisas de campo com secundaristas a respeito sobre seus anseios para o futuro. Com um recorte geográfico, de gênero e socioeconômico, estudaram duas escolas da cidade de Brasília (região de classe média alta), uma privada e uma pública, e duas escolas da cidade-satélite de Taguatinga (região de classe média e média baixa), seguindo os mesmos critérios. Ao todo foram entrevistados 48 alunos a respeito de 6 eixos temáticos, no entanto, para melhor encaixe no presente trabalho, será posto em questão principalmente os eixos 2 e 4, nominados, respectivamente, como "Expectativas quanto ao ingresso em uma universidade/faculdade" e "expectativas quanto a emprego, profissão e carreira". Em relação ao eixo 2, apesar de uma quantidade mais significativa de respostas positivas, as escolas da cidade menor se apresentaram mais negativas, em especial a da rede pública, corroborando com o ponto levantado por Oliveira e Saldanha (2010), quanto à indecisão associada à falta de expectativa de ingresso na universidade. O estudo apontou ainda que as respostas negativas dos alunos da rede privada estavam associadas à pressão da transição para a vida adulta e de passar no vestibular, não tendo uma preocupação real de ingressar no mercado de trabalho logo, enquanto os estudantes da rede pública estão preocupados em inserir-se rapidamente no mercado de trabalho para auxiliar no sustento de casa. A partir da análise dos comentários, o grupo da escola pública de Taguatinga foi o que mais demonstrou preocupação, que leva à hipótese de que para eles a

"qualificação profissional é tida como o meio de acesso a uma atividade remunerada, consoante ou não com suas preferências pessoais e que a Universidade constitui uma meta 
que, embora valorizada, é vista como inalcançável" (OLIVEIRA; PINTO; SOUZA, 2003).

O grupo de estudantes do gênero feminino apresentou, em todos os eixos maior quantidade de respostas negativas. Como o presente trabalho busca uma visão mais geral, não se aprofundará nesse aspecto, no entanto, cabe aqui a chamada de atenção e o convite à reflexão das perspectivas de futuro que atingem níveis e expectativas diferentes entre as meninas-mulheres e os meninos-homens, levando em consideração as experiencias, violências, restrições e papéis sociais que os gêneros costumam receber em nossa sociedade.

Existem ainda muitos outros trabalhos, produzidos em outros contextos do país, mas a partir dos estudos apresentados, pode-se começar a notar padrões que servirão ao propósito deste estudo. Percebe-se que a juventude brasileira busca sua felicidade e está preocupada com os rumos que suas vidas tomarão, mas que de acordo com o meio social em que está inserido, as esperanças de realizar seus objetivos e as pressões que recebem se distinguem.

A partir da compreensão da educação como direito de todo cidadão, e como elemento fundamental para a transformação individual e social, defender-se-á aqui o acesso da população das camadas mais pobres ao ensino gratuito e de qualidade que o Estado oferece, e que se mostra alheio à realidade muitas vezes. A intenção aqui não é colocar as faculdades particulares como inferiores, nem defender que estar em uma universidade pública seja a única forma de realização, mas apontar que os rumos tomados pelos indivíduos devem ser feitos por escolhas conscientes e não por falta de possibilidades e informações. Para fortalecer o argumento de que a falta de informação, leva à falta de interesse ou ao medo em relação à mudança, será apresentado o exemplo local da relação da UNESP - Franca e o ensino médio da região.

Para melhor contextualização a UNESP é uma universidade estadual, criada em 1976, e que possui 34 unidades espalhadas no estado de São Paulo, no campus de Franca, oferece 4 cursos de graduação: História, Direito, Serviço Social e Relações Internacionais, e está inserida na cidade há mais de 50 anos. A universidade é a mais aberta entre as estaduais paulistas para a entrada de estudantes de escolas públicas, tendo um sistema de reserva de vagas, onde a partir do ano de $2018,50 \%$ das vagas, de todos os cursos são reservadas à tal público.

Segundo consta no IBGE - Instituto Brasileiro de Geografia e Estatística, a diretoria de ensino de Franca e São Joaquim da Barra, tinham 7556 alunos matriculados na $3^{\circ}$ série do ensino médio no ano de 2018. A Fundação Vunesp, responsável pelos vestibulares da UNESP, separa essas duas diretorias de ensino na "cidade posto" de Franca, e cedeu dados 
referentes ao vestibular aplicado 2018, para ingresso em 2019. Na hora de se inscrever no vestibular, a fundação Vunesp disponibiliza um código para a redução da taxa de inscrição para os alunos da rede pública de ensino, e para essa pesquisa a diretoria da unidade de Franca disponibilizou os dados referentes à "cidade posto" de Franca (Anexo A - Dados referentes às inscrições para o vestibular da UNESP - "cidade-posto" Franca) com a quantidade de inscritos nesta modalidade e a de matriculados, em qualquer curso da instituição, em todos os seu campus, sendo respectivamente, $421 \mathrm{e}$ 18. O número de inscritos no vestibular corresponde a $5,57 \%$ dos alunos que se formaram em 2018, e é um número extremamente baixo se levarmos em conta que há um campus da dita universidade na cidade/região em que habitam, a partir daí pode-se questionar se a presença da mesma tem sido efetiva e qual seu nível de relação com a comunidade local.

Com bases empíricas, como graduanda, extensionista, participante do Programa Institucional de Bolsas de Iniciação à Docência (Pibid) e a partir da participação da divulgação do vestibular em 10 escolas estaduais do município no ano de 2018, percebo que há grande distanciamento da Universidade para com a comunidade francana, tendo as extensões papel importante como pontos de contato, mas mesmo com o trabalho realizados por estas existe uma ideia de que o acesso à universidade é algo para a elite e uma possibilidade extremamente longínqua, além de que nem todas possuem estudantes do ensino médio como público alvo. Durante o trabalho de divulgação, realizado pela Fundação Vunesp, ao entrar em contato direto com os alunos, para falar sobre a universidade, políticas de permanência e instruções para inscrição tudo se mostrava como muita novidade, a existência da UNESP na cidade sequer era conhecida pela maioria dos estudantes e a possibilidade de cursar ensino superior gratuito muito menos. O papel social da faculdade, o tripé educacional de ensino, pesquisa e extensão, e as políticas de permanência estudantil não são apresentados antes da inserção no contexto universitário, ponto levantado também por outros graduandos oriundos de escolas públicas.

A falta de informação é um primeiro ponto, além da falta de conhecimento das políticas de permanência, e todas as questões relativas à mudança de cidade muitas vezes, a falta de recursos financeiros e de incentivo da rede familiar, existem outras questões que são importantes para 0 distanciamento entre a academia e a população, como critica Marilena Chauí (2003), com o fato de as universidades estarem se apresentando mais como organizações sociais do que como instituições sociais, absorvendo a lógica produtivista e capitalista, em lugar de produzir conhecimento de qualidade e revertê-lo para o bem da população.

\section{CONCLUSÃO}


A partir da análise realizada, vê-se que o desejo da juventude brasileira consiste na busca pela felicidade, que devido à lógica social que rege o país, está associada à estabilidade financeira alcançada por meio do trabalho, os adolescentes das camadas ricas e pobres tem os mesmos anseios por relações afetivas saudáveis e colocação social alta, no entanto, devido às suas posições e realidades tem caminhos diferentes e oportunidades muito distintas. Apesar de buscarem um mesmo objetivo, e enxergarem na educação um caminho para alcançar sucesso no mercado de trabalho, os jovens das camadas menos favorecidas não possuem tanta esperança de atingi-lo, e atrelam o ensino como meio de ascensão social, mas reconhecem que não estão preparados para competir com os mais abastados financeiramente, então para aqueles que tem como meta continuar os estudos, pensam em trabalhar para pagar um cursinho ou uma faculdade privada.

A distância entre o jovem periférico e a universidade pública é um fenômeno que pode ser percebido claramente, e que foi apresentado com maior ênfase no caso local da região de Franca e da UNESP, que possui um campus na cidade. A universidade não tem cumprido com eficácia seu papel social, mostrando-se alheia à realidade da comunidade, e sendo vista como um lugar elitizado destinado às pessoas de outras cidades e classes sociais. Esse fenômeno pode ser sentido no país, como se pode perceber nas falas e crenças populares de muitos sobre a universidade pública, como um lugar de bagunça e com pouca utilidade social.

O modo como a educação vem sendo encarada, e reproduzida apenas com um viés mercadológico e servindo à lógica capitalista é problemática e a seu respeito caberiam outras reflexões e análises. Entretanto, apesar dessas questões o acesso à educação e a permanência no sistema educacional são direitos que devem ser garantidos aos cidadãos e ainda se apresentam como meio de diminuir as desigualdades, portanto defende-se que é preciso trabalhar na informação e em uma melhor relação entre a universidade e a comunidade, incentivando e lutando pela democratização do ensino, exaltando as potencialidades dos jovens brasileiros e entendendo que é um direito comum.

\section{REFERÊNCIAS}

ALMEIDA, Wilson Mesquita. Acesso à universidade pública brasileira: posições em disputa. Disponível em: https://periodicos.ufpe.br/revistas/revsocio/article/view/235247/28268

BARROS, Lucas Guimarães; DUTRA, Glênon; CONCEIÇÃO, Lilian. Reflexões sobre as perspectivas de futuro profissional dos alunos de uma escola pública do município de Amargosa - BA. Disponível em: 
https://ufrb.edu.br/pibid/documentos/category/8-

artigos?download=43:artigo-reflexoes-sobre-as-perspectivas-de-futuroprofissional

BRASIL/MEC. Lei no. 9.394, de 20 de dezembro de 1996. Lei de Diretrizes e Bases da Educação Nacional. Brasília, DF: 20 de dezembro de 1996.

CABRAL, Dimas Della Torre Sousa. Ensino Médio na perspectiva de estudantes de uma escola pública da periferia de São Paulo, 2017. Dissertação (Mestrado em Educação (Psicologia da Educação)) - Pontifícia Universidade Católica de São Paulo.

CARVALHO, MÁrcia Marques de; WALTENBERG, FÁbio D.. DESIGUALDADE DE OPORTUNIDADES NO ACESSO AO ENSINO SUPERIOR NO BRASIL: UMA COMPARAÇÃO ENTRE 2003 E 2013. Economia Plicada, Ribeirão Preto, v. 19, n. 2, p.1-2, jun. 2015. Disponível em:

$<$ http://www.scielo.br/scielo.php?script=sci_arttext\&pid=S1413-

80502015000200369 >. Acesso em: 30 ago. 2019.

CHAUI, Marilena. A universidade pública sob nova perspectiva. Rev. Bras. Educ. [online]. 2003, n.24, pp.5-15. ISSN 1413-2478.

IBGE. Instituto Brasileiro de Geografia e Estatística - IBGE: disponível em: https://cidades.ibge.gov.br/brasil/sp/saopaulo/pesquisa/13/5908?indicador $=77910$ \&tipo=ranking \&localidade $1=3520$ $\underline{50}$

MARCELINO, Maria Quitéria dos Santos; CATÃO, Maria de Fátima Fernandes Martins; LIMA, Claudia Maria Pereira de. Representações Sociais do Projeto de Vida entre Adolescentes no Ensino Médio. Psicologia, Ciência e Profissão, Paulo Afonso, v. 29, n. 3, p.544-557, jan. 2009. Disponível em: <http://www.scielo.br/pdf/pcp/v29n3/v29n3a09>. Acesso em: 30 ago. 2019.

OLIVEIRA, Isabel Cristina Vasconcelos de; SALDANHA, Ana Alayde Werba. Estudo comparativo sobre a perspectiva de futuro dos estudantes de escolas públicas e privadas. Paidéia (ribeirão Preto), [s.l.], v. 20, n. 45, p.4755, abr. 2010. FapUNIFESP (SciELO). http://dx.doi.org/10.1590/s0103$863 \times 2010000100007$.

OLIVEIRA, Maria Cláudia Santos Lopes de; PINTO, Raquel Gomes; SOUZA, Alessandra da Silva. Perspectivas de futuro entre adolescentes: universidade, trabalho e relacionamentos na transição para a vida adulta. Temas em Psicologia, Ribeirão Preto, v. 11, n. 1, p.1-2, jun. 2003. Disponível em: <http://pepsic.bvsalud.org/scielo.php?script=sci_arttext\&pid=S1413389X2003000100003\#la>. Acesso em: 30 ago. $201 \overline{9}$. 


\section{ANEXOS}

\section{Anexo A - Dados referentes às inscrições para o vestibular da UNESP - "cidade-posto" Franca}

\section{unesp}

Cidade Posto: Franca

Diretoria de Ensine 036 - Franca

odade - nome da escola

CRISTAIS PAULISTA - JOAO DE FARIA

FRANCA - ADELINA PASQUINO CASSIS PROFA

FRANCA - ADELMO FRANCISCO DA SILVA

FRANCA - AGOSTINHO LIMA DE VILHENA PROF

FRANCA - ANA MARIA JUNQUEIRA PROFA

FRANCA - ANGELO GOSUEN PROF

FRANCA - ANGELO SCARABUCCI

FRANCA - ANTONIO FACHADA PROF

FRANCA - CARMEM MUNHOZ COELHO PROFA

FRANCA - DAVID CARNEIRO EWBANK

FRANCA - ETEC DOUTOR JÚLIO CARDOSO

FRANCA - ETEC PROFESSOR CARMELINO CORREA JÚNIOR

FRANCA - EVARISTO FABRICIO PROF

FRANCA - HELENA CURY DE TACCA PROFA

FRANCA - HELIO PALERMO PROF

FRANCA - ISRAEL NICEUS MOREIRA PROF

FRANCA - JOAO MARCIANO DE ALMEIDA DR

FRANCA - JOSE PINHEIRO DE LACERDA CAPITAO

FRANCA - LUIZ PARIDE SINELLLI PROF

FRANICA MARIA PIA SILVA CASTRO PROFA

FRANCA - MARIO D ELIA

FRANCA - ODETTE BUENO RIBEIRO PROFESSORA

FRANCA - ORLIK LUZ DR

FRANCA - OTAVIO MARTINS DE SOUZA PROF

FRANCA - PEDRO NUNES ROCHA PROF

FRANCA - PROFESSORA STELLA DA MATTA AMBROSIO

FRANCA - SERGIO LECA TEIXEIRA PROF

FRANCA - SUDARIO FERREIRA

FRANCA - TORQUATO CALEIRO

ITIRAPUA - HENRIQUE LESPINASSE PROF

JERIQUARA - OLIVIO PEIXOTO PROF

PATROCINIO PAULISTA - JORGE FALEIROS

PEDREGULHO - JOSE VICENTE MACHADO NETTO DR

PEDREGULHO - MARIA APARECIDA SALES MANREZA PROFA

RESTINGA - ISAAC VILELA DE ANDRADE

RIBEIRAO CORRENTE - NENE LOURENCO

RIFAINA - HENRIQUETA RIVERA MIRANDA PROFA

SAO JOSE DA BELA VISTA - MACIEL DE CASTRO JUNIOR

dos candidatos inscritos e matriculados da escola pública

Diretorla de Ensino

\section{7 - São Joaquim da Barra}

cidade - nome da escola

GUARA - RONDON MARECHAL

IGARAPAVA - ETEC ANTONIO JUNQUEIRA DA VEIGA

IPUA - ANTONIO FRANCISCO D AVILA

TUVERAVA - ANTONIO JUSTINO FALLEIROS CAPITAO

WUVERAVA - ETEC PROFESSOR JOSÉ IGNACIO AZEVEDO FILHO

inscritos matriculados

\begin{tabular}{|c|}
\hline 02 \\
\hline 10 \\
\hline 02 \\
\hline 03 \\
\hline 27 \\
\hline
\end{tabular}

\begin{tabular}{|l|}
\hline 00 \\
\hline 00 \\
\hline 00 \\
\hline 01 \\
\hline 01 \\
\hline
\end{tabular}




\section{unesp}

Cidade Posto: Franca

\section{VESTIBULAR 2019}

Página: 14 de 70

Resumo por escola dos candidatos inscritos e matriculados da escola pública (redução de taxa - R\$ 42,50)

Diretoria de Ensino

077 - São Joaquim da Barra

cidade - nome da escola

MIGUELOPOLIS - ETEC LAURINDO ALVES DE QUEIROZ

MIGUELOPOLIS - WILLIAN AMIN DOUTOR

ORLANDIA - ETEC PROFESSOR ALCIDIO DE SOUZA PRADO

ORLANDIA - OSWALDO RIBEIRO JUNQUEIRA

SAO JOAQUIM DA BARRA - EDDA CARDOZO DE SOUZA MARCUSSI

SAO JOAQUIM DA BARRA - ETEC PEDRO BADRAN

SAO JOAQUIM DA BARRA - GENOVEVA PINHEIRO VIEIRA DE VITTA PROFESSORA

SAO JOAQUIM DA BARRA - MANOEL GOUVEIA DE LIMA

Resumo da DE:

inscritos matriculados

\begin{tabular}{|c|}
\hline 10 \\
\hline 03 \\
\hline 47 \\
\hline 04 \\
\hline 02 \\
\hline 34 \\
\hline 02 \\
\hline 06 \\
\hline 152 \\
\hline 421 \\
\hline
\end{tabular}

\begin{tabular}{|l|}
\hline 00 \\
\hline 00 \\
\hline 04 \\
\hline 00 \\
\hline 00 \\
\hline 03 \\
\hline 00 \\
\hline 00 \\
\hline 09 \\
\hline 18 \\
\hline
\end{tabular}

421 
JUVENTUDE E OS PROGRAMAS DE APRENDIZAGENS: O que dizem as pesquisas?

\author{
MOHERDAUI, Isabela Cintra \\ Mestranda - UNESP/Franca \\ isa_cintra12@hotmail.com \\ GRACIOLI, Maria Madalena \\ Docente - UNESP/Franca \\ lenagracioli@gmail.com
}

\title{
1. INTRODUÇÃO
}

O tema juventude se faz cada vez mais presente na pauta das políticas públicas, demonstrando a existência da preocupação de diversos setores da sociedade acerca do futuro dos jovens, o qual ainda é visto como um problema social. O conceito de jovem, como tema presente em nosso cotidiano, deve ser discutido como uma construção social, uma vez que nos deparamos com diferentes realidades econômicas, sociais e culturais.

Novaes (2006) defende que dizer que os jovens são os indivíduos que nasceram há 14 ou 24 anos poderia ser uma conclusão, porém esses marcos de idade não são vistos como permanentes, pois os que não tiveram direitos de ser criança começam a juventude mais cedo, enquanto, a outra parcela de pessoas (com o aumento da perspectiva de vida e transformações no mundo do trabalho) aumenta o período da juventude até os 30 anos. Nesse mesmo sentido, os jovens podem estar com a mesma idade, mas não significa que vivenciam a mesma juventude.

Assim, pode-se presumir que as vivências com relação a estudo e trabalho podem variar de acordo com o indivíduo. Entende-se que a juventude representa um período em que os indivíduos iniciam o seu projeto de vida, planejando as realizações que pretendem atingir. Em relação ao mundo do trabalho, existem grupos juvenis, os de classe social mais baixas, que vivenciam a angústia da necessidade de inserção no mundo do trabalho mais cedo.

Tendo em vista a dificuldade de inserção e permanência de jovens de baixa renda no mundo trabalho, foram identificadas necessidades de políticas públicas para facilitar a inserção laboral desses jovens, entre elas a política de Aprendizagem Profissional, assentada na Lei Federal 10.097/2000, dando origem aos Programas de Aprendizagem, que tem como objetivo oferecer capacitação aos jovens aprendizes neles inseridos. 
Esse estudo, de cunho qualitativo, tem como objetivo conhecer as produções acadêmicas sobre o tema juventude e Programas de Aprendizagem Profissional, recorrendo à pesquisa bibliográfica denominada estado da arte ou estado do conhecimento, identificando a produção científica destinada a este tema, assim debruçamos sobre produções científicas publicadas entre 2000 e 2018. Para a busca, foram utilizados os seguintes descritores: aprendiz, jovem aprendiz, juventude, programa aprendizagem profissional, programa de aprendizagem, e também o cruzamento dos descritores como juventude e trabalho, jovem aprendiz e Programa de Aprendizagem. Iniciaremos a discussão sobre juventude e sua relação com o mundo do trabalho e, em seguida, os Programas de Aprendizagem.

\section{JUVENTUDE E MUNDO DO TRABALHO}

Muitos estudos são produzidos para superar a ideia de jovem como problema social, visando identificar suas potencialidades enquanto sujeito ativo e de direitos.

De acordo com Ravasco, Maia e Mancebo (2010, p. 381) "a juventude, assim como as outras fases da vida, é uma construção social, histórica e cultural, de modo que, em cada momento histórico, ela possui funções, representações e significações diferenciadas".

Dayrell (2007) define os jovens como indivíduos que sentem amor, refletem a respeito das suas vivências, defendem suas opiniões, têm objetivos e sugestões para melhoria de vida, sendo dessa maneira que cada indivíduo se estrutura como sujeito.

O Estatuto da Juventude (Lei 12.852/2013) entende que as pessoas com idade entre 15 e 29 anos de idade podem ser classificadas como jovens, já o IBGE considera os indivíduos entre 15 e 24 anos. O Estatuto da Juventude, IBGE e outras instituições utilizam essas ordens cronológicas para definir juventude, pois diz respeito a uma abordagem demográfica e está relacionada ao tempo em que ocorre a transição para a vida adulta, diferente dos estudos sociológicos que focam nas condições sociais de cada sociedade. Nesse artigo, assumiremos a definição de jovens recorrendo aos estudos sociológicos e considerando os jovens enquanto categoria social, formulada em múltiplos contextos, como econômico, social, político e cultural, compreendendo as diversas juventudes que convivem na sociedade.

Geralmente é na juventude que dá as primeiras experiências de inserção no mundo do trabalho, nesse sentido o trabalho pode ser considerado como meio de inserção social e elaboração de subjetividade. Ravasco, Maia e Macebo (2010) e Leon (2009) defendem que a atividade laboral econômica, além de ser um caminho para alcançar objetivos pessoais e construção da 
personalidade e identidade, também auxilia na edificação dos projetos de futuro do jovem.

As mudanças no mundo do trabalho impactam diretamente na necessidade do aumento de indivíduos para trabalhar, exigindo destes maior escolaridade, aprimoramentos profissionais e tecnológicos e, ao mesmo tempo, visa-se gastar o menos com a formação desses possíveis trabalhadores. De acordo com Leon (2009), nas bases históricas, os jovens são considerados como aqueles que têm maior dificuldade de inserção laboral. Relacionando jovem e mundo do trabalho, Leon (2009, p.272) afirma que "as questões do trabalho e da renda da juventude refletem o difícil processo de inserção e permanência do jovem no mundo do trabalho".

Considerando as dificuldades de inserção, principalmente das camadas mais vulneráveis da sociedade e considerando inclusão dos jovens nas pautas das políticas públicas, foram criadas políticas públicas voltadas a preparar o jovem para o ingresso no mercado do trabalho, algumas dessas políticas foram desenhadas em forma de programas, visando amenizar a dificuldade de inserção no trabalho, principalmente dos jovens de baixa renda.

Baseadas no Guia de Políticas Públicas de Juventude (BRASIL,2006), percebe-se que nos últimos anos têm ocorrido muitas mudanças no âmbito social, econômico e cultural, influenciando os padrões da economia, convívio social, e trabalhistas no mundo. Isso traz como consequência novas discrepâncias sociais, que demandam novas formas de enfrentamento por parte do planejamento de políticas públicas. Segundo o Guia, os jovens constituem o público que mais sofre com as mudanças no mundo do trabalho e nas diferentes maneiras de violência no século $X X I$. No Brasil, percebeu-se que o tema foi dado como essencial a partir da década de 1990, compreendendo a necessidade de políticas públicas relacionadas ao jovem no que diz respeito à educação e inserção no mundo do trabalho, destacaremos, em específico, a política de Aprendizagem Profissional.

\subsection{PROGRAMA DE APRENDIZAGEM PROFISSIONAL}

A Política de Aprendizagem Profissional, advinda da Lei Federal 10.097/2000 (BRASIL, 2000), normatizada pelo Decreto $\mathrm{n}^{\circ} 5.598$ de $1^{\circ}$ de dezembro de 2005, obriga as empresas de médio e grande porte a contratar jovens, oferecendo a possibilidade de inserção do jovem de baixa no mundo do trabalho.

Referente ao número de jovens a serem vinculados como aprendizes às empresas, a Lei evidencia a necessidade de ser no máximo quinze por cento e no mínimo cinco por cento, com relação ao número de funcionários que participam do quadro da empresa. Os empreendimentos de 
micro e pequeno porte e também as instituições sem fins lucrativos que oferecem educação profissional não são obrigadas a contratar aprendizes (LEI FEDERAL No. 10.097/ 2000).

A faixa etária permitida para contratação é de, no mínimo, 14 anos e, no máximo, 24 anos. A Lei é clara quanto à contratação dos jovens, os quais devem ser contratados com uma jornada de quatro a seis horas diárias, com ressalva dos jovens que estiverem cursando o ensino médio no ensino regular, estes poderão trabalhar até oito horas diárias. Não são permitidas horas extras, nem compensação de horas. O contrato de trabalho é considerado contrato especial, com duração de no máximo dois anos (LEI FEDERAL No. 10.097/ 2000).

Com base no artigo 63 do Estatuto da Criança e do Adolescente (Brasil, 2000), que defende a importância de priorizar os estudos em relação a atividade laboral, essa Lei corrobora que os jovens aprendizes não podem somente ter atuação profissional, precisam, ao mesmo tempo, de capacitação intelectual em instituições voltadas para a política pública da aprendizagem profissional. $\mathrm{Na}$ ação da contratação de aprendizes, as empresas devem cadastrá-los em Serviços Nacionais de Aprendizagem, os quais oferecem essa capacitação, visto que o jovem aprendiz não pode só exercer práticas profissionais, devem aliar o exercício profissional ao curso oferecido por Serviços Nacionais de Aprendizagem. Segundo Gonçalves (2014, p.191):

O Programa de Aprendizagem Profissional deve prever a alternância de aulas teóricas e atividades práticas à ocupação/profissão objeto da formação daquele beneficiário, vivenciadas nas entidades formadoras habilitadas e nas empresas contratantes, respectivamente.

O Programa Nacional de Aprendizagem é uma ação do governo federal com o objetivo de incluir jovens maiores de 14 anos no mercado formal de trabalho, proporcionando assim mais possibilidades de jovens sem experiência terem acesso à vida profissional, aliando essa prática aos estudos.

\section{METODOLOGIA E ANÁLISE DOS DADOS}

O presente estudo pode ser caracterizado como exploratório de caráter qualitativo, diz respeito a uma pesquisa bibliográfica que utiliza o estado da Arte. Esse tipo de estudo pode ser entendido como pesquisa bibliográfica que tem a ação de averiguar e procurar informações através de um levantamento em bases de dados, com a finalidade de revelar o que se encontra de produção relacionada a alguma área de conhecimento. Ferreira (2002, p.258) explica que: "[...] definidas como de caráter bibliográfico, elas parecem trazer em comum o desafio de mapear e de discutir uma certa produção acadêmica em diferentes campos do conhecimento [...]". 
Para atingir os objetivos, valeu-se das bases de dados Scientific Electronic Library Online (Scielo), Biblioteca da Universidade Estadual Paulista "Júlio de Mesquita Filho" (UNESP) e Coordenação de Aperfeiçoamento de Pessoal de Nível Superior (CAPES), de pesquisas publicadas entre os anos 2000 e 2018. Esse recorte foi realizado para identificar pesquisas mais recentes sobre o tema.

Para elegibilidade das pesquisas foram considerados ano de publicação, título e resumo, tendo como temas centrais o jovem e programas de aprendizagens.

3.1 PRODUÇÕES E ANÁLISES DOS DADOS OBTIDOS NAS PLATAFORMAS SCIENTIFIC ELECTRONIC LIBRARY ONLINE (SCIELO), BIBLIOTECA DA UNIVERSIDADE ESTADUAL PAULISTA "JÚLIO DE MESQUITA FILHO" (UNESP) E COORDENAÇÃO DE APERFEIÇOAMENTO DE PESSOAL DE NÍVEL SUPERIOR (CAPES) $(2000-2018)$

A metodologia para analisar o "estado da arte" nos possibilitou estruturar e discutir a produção acadêmica na área de juventude e programas de aprendizagem. Assim, com o objetivo de conhecer o estado da arte nessa área, descrevemos abaixo os trabalhos localizados, apontando o tipo de publicação (artigos científicos, dissertação ou trabalho de conclusão de curso), autoria, título, ano de publicação, bem como um pequeno resumo sobre metodologia utilizada e resultados.

A princípio, na plataforma Coordenação de Aperfeiçoamento de Pessoal de Nível Superior (CAPES), foi utilizado o descritor Programa de Aprendizagem e também o cruzamento dos descritores programa de aprendizagem e aprendiz. Nas plataformas Scielo e Biblioteca da Universidade Estadual Paulista de Franca-SP, para a busca das pesquisas, foram utilizados os descritores: aprendiz, jovem aprendiz, juventude, programa aprendizagem profissional e programa de aprendizagem. O cruzamento de descritores também foi utilizado como juventude e trabalho, jovem aprendiz e Programa de Aprendizagem.

O recorte temporal pesquisado foi de 18 anos, mais precisamente de 2000 a 2018, o artigo científico mais antigo encontrado foi do ano de 2011, já com relação a dissertações e trabalhos de conclusão de curso, a publicação mais antiga foi referente ao ano de 2001. Ao todo, foram encontrados 16 estudos.

A maioria das pesquisas que foram encontradas nas três plataformas (Scielo, CAPES e Biblioteca da Universidade Estadual Paulista de Franca-SP) são pesquisas que correspondem às análises qualitativas. As pesquisas selecionadas utilizaram diversos instrumentos metodológicos, como 
a entrevista semiestruturada, questionários abertos e semiestruturados e o survey.

Tabela 1 - Relação de artigos

\begin{tabular}{|c|c|c|c|c|c|}
\hline Título & Autor(ores) & Metodologia & $\begin{array}{l}\text { Universidade } \\
\text { e/ou revista }\end{array}$ & Tipo & Ano \\
\hline $\begin{array}{c}\text { Programa de } \\
\text { aprendizagem: } \\
\text { imagem e } \\
\text { satisfação na visão } \\
\text { dos aprendizes }\end{array}$ & $\begin{array}{c}\text { Suzete } \\
\text { Antonieta } \\
\text { Lizote; } \\
\text { Miguel Angel } \\
\text { Verdinelli; } \\
\text { Elisa Couto } \\
\text { Laurentino; } \\
\text { Thais Cristina } \\
\text { Melim Petrel; } \\
\text { Luana da } \\
\text { Silva Santos }\end{array}$ & $\begin{array}{c}\text { Quantitativa; } \\
\text { questionário } \\
\text { survey }\end{array}$ & $\begin{array}{l}\text { Universidade do } \\
\text { Vale do Itajaí- } \\
\text { SC; RACE; } \\
\text { Revista de } \\
\text { Administração, } \\
\text { Contabilidade e } \\
\text { Economia. }\end{array}$ & Artigo & 2015 \\
\hline $\begin{array}{l}\text { Formação } \\
\text { profissional: as } \\
\text { vivências dos } \\
\text { jovens em um } \\
\text { programa de } \\
\text { aprendizagem }\end{array}$ & $\begin{array}{l}\text { Manuella } \\
\text { Castelo } \\
\text { Branco } \\
\text { Pessoa; Maria } \\
\text { de Fátima } \\
\text { Pereira } \\
\text { Alberto }\end{array}$ & $\begin{array}{c}\text { Qualitativa/ } \\
\text { entrevista } \\
\text { semiestruturada }\end{array}$ & $\begin{array}{l}\text { Universidade } \\
\text { Federal da } \\
\text { Paraíba-PB; } \\
\text { Revista Estudos } \\
\text { Interdisciplinares } \\
\text { em Psicologia }\end{array}$ & Artigo & 2015 \\
\hline $\begin{array}{l}\text { Adolescentes } \\
\text { aprendizes: } \\
\text { aspectos da } \\
\text { inserção } \\
\text { profissional e } \\
\text { mudanças na } \\
\text { percepção de si }\end{array}$ & $\begin{array}{l}\text { Renata } \\
\text { Danielle } \\
\text { Moreira Silval; } \\
\text { Zeidi Araujo } \\
\text { Trindade }\end{array}$ & $\begin{array}{c}\text { Qualitativa/ } \\
\text { entrevista } \\
\text { semiestruturada }\end{array}$ & $\begin{array}{c}\text { Universidade } \\
\text { Federal do } \\
\text { Espírito Santo; } \\
\text { Revista } \\
\text { Brasileira de } \\
\text { Orientação } \\
\text { Profissional }\end{array}$ & Artigo & 2013 \\
\hline $\begin{array}{l}\text { As representações } \\
\text { sociais do trabalho } \\
\text { entre adolescentes } \\
\text { aprendizes - um } \\
\text { estudo piloto }\end{array}$ & $\begin{array}{l}\text { Elsa de } \\
\text { Mattos; } \\
\text { Antonio } \\
\text { Marcos } \\
\text { Chaves }\end{array}$ & $\begin{array}{l}\text { Qualitativa/ } \\
\text { questionário } \\
\text { aberto }\end{array}$ & $\begin{array}{c}\text { Universidade } \\
\text { Federal da } \\
\text { Bahia; Revista } \\
\text { Brasileira } \\
\text { Crescimento e } \\
\text { Desenvolvimento } \\
\text { Humano }\end{array}$ & Artigo & 2006 \\
\hline $\begin{array}{c}\text { Trabalho e escola: } \\
\text { é possível } \\
\text { conciliar? A } \\
\text { perspectiva de } \\
\text { jovens aprendizes } \\
\text { baianos }\end{array}$ & $\begin{array}{l}\text { Elsa de } \\
\text { Mattos; } \\
\text { Antônio } \\
\text { Marcos } \\
\text { Chaves }\end{array}$ & $\begin{array}{c}\text { Qualitativa; } \\
\text { entrevista } \\
\text { semiestruturada, } \\
\text { questionário } \\
\text { sociodemográfico } \\
\text { e observação } \\
\text { participativa }\end{array}$ & $\begin{array}{l}\text { Universidade } \\
\text { Federal da } \\
\text { Bahia; Revista } \\
\text { Psicologia } \\
\text { Ciência e } \\
\text { Profissão }\end{array}$ & Artigo & 2010 \\
\hline $\begin{array}{c}\text { Juventude e } \\
\text { Educação } \\
\text { Profissionalizante: } \\
\text { Dimensões } \\
\text { Psicossociais do } \\
\text { Programa Jovem } \\
\text { Aprendiz }\end{array}$ & $\begin{array}{c}\text { Maria de } \\
\text { Fatima } \\
\text { Quintal de } \\
\text { Freitas; Lygia } \\
\text { Maria } \\
\text { Portugal de } \\
\text { Oliveira }\end{array}$ & $\begin{array}{c}\text { Qualitativa; } \\
\text { questionário } \\
\text { semiestruturado }\end{array}$ & $\begin{array}{c}\text { Universidade } \\
\text { Federal do } \\
\text { Paraná; Revista } \\
\text { Psicologia em } \\
\text { Pesquisa }\end{array}$ & Artigo & 2012 \\
\hline
\end{tabular}

Fonte: elaborado pelas autoras.

Os seis artigos acima, localizados na Plataforma CAPES, versam sobre os temas: contribuições do Programa de Aprendizagem com a perspectiva dos jovens aprendizes; fatores que levaram os jovens a se inserirem no Programa de Aprendizagem; os impactos da relação entre educação e profissionalização na perspectiva dos jovens; representações 
sociais de jovens aprendizes sobre 0 trabalho e a relação entre trabalho e estudo. Cinco artigos utilizaram análise qualitativa e um valeu-se de análise quantitativa. A maioria das pesquisas encontradas foram de cunho qualitativo, com método exploratório, foram utilizados questionários semiestruturados, questionário sociodemográfico e entrevistas semiestruturadas como instrumento de coleta de dados. Somente um estudo utilizou como metodologia o método aplicado e descritivo de cunho quantitativo e o questionário survey como instrumento para coleta de dados. A maioria das pesquisas dessa plataforma realizaram análise de conteúdo. Todas as pesquisas apontam aspectos positivos da inserção dos jovens nos Programas de aprendizagem, tais como; possibilidade de construir um caminho profissional; aprimoramento profissional; constituição de renda própria e independência financeira; vivência do primeiro emprego; habilidades sociais; aumento da proatividade; aprimoramento de competências e aquisição de novas habilidades. No entanto, todos eles também apontam questões negativas com a dificuldade de conciliar estudo e trabalho; aquisição de responsabilidades do mundo adulto demasiadamente pesadas para os jovens, tornando-os antecipadamente adultos; tempo escasso para atividades extras, principalmente para as jovens aprendizes, assim como priorizar o trabalho em relação ao estudo. Dessa forma, nota-se que as vertentes positivas superam as negativas.

Programa de aprendizagem: imagem e satisfação na visão dos aprendizes. Analisou-se 0 conceito e satisfação de aprendizes sobre 0 programa de aprendizagem do Instituto Crescer. Consultou-se a legislação que expõe o tema da Aprendizagem Profissional no Brasil. Este estudo foi de cunho quantitativo. Baseou-se na pesquisa de Survey através de um questionário aplicado em jovens atendidos pelo Instituto. Buscou-se informações pessoais, expectativas sobre o trabalho e entendimento dos jovens sobre a imagem e satisfação sobre o Programa de Aprendizagem. $O$ estudo concluiu que as respostas dos jovens aprendizes são positivas com relação ao processo de desenvolvimento do programa, que a maioria entende como importante inserir no mercado formal de trabalho como aprendizes, essa vivência oportunizará sua inserção no mundo do trabalho, além de contribuir para escolher seu caminho profissional e auxiliar no aprimoramento profissional.

Formação profissional: as vivências dos jovens em um programa de aprendizagem. Este estudo teve como objetivo analisar as experiências de jovens participantes de um Programa de Aprendizagem. Participaram da pesquisa 20 jovens, dentre 98 integrantes do Programa Jovem Aprendiz realizado por uma instituição específica da cidade de João Pessoa-PB. Os dados do estudo demonstraram que os jovens associaram suas necessidades econômicas e de suas famílias à expressão de que é essencial adquirir experiência profissional para se inserir no mercado. Os aprendizados advindos do programa proporcionaram: formação profissional; adquirir vivências; conhecer técnicas bancárias; conquistar o primeiro emprego. A pesquisa 
também captou que ao mesmo tempo que o Programa oferece oportunidades permite sofrimento, pois o jovem adquire responsabilidades sentidas como pesadas, tornando-os adultos antecipadamente.

Adolescentes aprendizes: aspectos da inserção profissional e mudanças na percepção de si. Objetivou-se identificar fatores que levaram jovens a ingressarem em Programa de Aprendizagem Profissional (PAP) e as mudanças percebidas por esse fato. Contou-se com 22 participantes, com idades entre 15 e 17 anos, de um Programa de Aprendizagem de Vitória- ES. O estudo concluiu que os jovens aprendizes expuseram mudanças positivas advindas da experiência no Programa como profissional, aquisição de habilidades sociais e independência. Sobre as mudanças negativas, como cansaço e tempo escasso para atividades extras foram apontados mais pelas meninas e evidenciou que aspectos positivos são maiores que os negativos.

As representações sociais do trabalho entre adolescentes aprendizes - um estudo piloto. Esse estudo teve como objetivo investigar as representações sociais de adolescentes aprendizes sobre o trabalho e a relação entre trabalho e estudo. Foi desenvolvido com 70 jovens com idades entre 15 e 18 anos, participantes de um programa de aprendizagem desenvolvido em uma ONG situada em Salvador (Bahia). A partir dos resultados, concluiu-se que a partir da vivência do trabalho foi destacado a aquisição do salário e realização de tarefas. Com relação ao desenvolvimento pessoal, surgem questões relacionadas a aprendizagem e obtenção de experiência. Percebeu-se também a relação do jovem e trabalho, a importância dada por eles à aprendizagem e desenvolvimento aparenta ter ligação com a participação no Programa de Aprendizagem. No que tange ao estudo e trabalho, mostrou algo mais complicado, pois exige mais empenho dos jovens em conciliar as duas áreas.

Trabalho e escola: é possível conciliar? A perspectiva de jovens aprendizes baianos. Este artigo é parte de um estudo que pesquisou experiências de trajetória para o trabalho de jovens aprendizes baianos. 0 objetivo foi entender os significados levantados pelos jovens sobre as relações entre trabalho e escola. Participaram da pesquisa 10 adolescentes, de ambos os sexos, com idades entre 17 e 19 anos, egressos de um programa de aprendizagem. O estudo concluiu que a atividade laboral relacionada ao aprendiz é percebida como capaz de trazer mudanças positivas envolvendo aumento de proatividade, aprimoramento de competências bem como aquisição de novas habilidades. Contudo, trabalhar e estudar exige planejamento e estratégias do jovem aprendiz, configurando-se como desafio na rotina. Através disso, a pesquisa concluiu que trabalho e estudo são áreas coexistentes e não podem ser vistos de forma separada, chegando ao ponto dos alunos perceberem o trabalho como realidade e o estudo como ilusório. 


\section{Juventude e Educação Profissionalizante: Dimensões}

Psicossociais do Programa Jovem Aprendiz. Este artigo teve como objetivo analisar os impactos psicossociais da relação entre educação e ensino profissionalizante pela percepção de jovens participantes de um Programa de Aprendizagem. Com relação aos motivos do ingresso e permanência no programa, agruparam-se em categorias: aprimoramento através do estudo e formação; chances de ter um trabalho, ter uma profissão e recursos próprios; e possibilidade de ajudar a família. No que tange as expectativas de sonhos de futuro e objetivos pessoais, os jovens indicaram motivos ligados à aquisição de conhecimento. São motivações: a busca por qualificação e trabalho (38,66\%); o desejo de aprimorar a educação e formação $(31,90 \%)$; possuir bens materiais (7,90\%); ser feliz e com qualidade de vida (6,75\%); formar família $(5,52 \%)$; e ser alguém na vida $(4,29 \%)$. Estes pontos aparentaram mostrar uma relação entre formação e mundo do trabalho como fundamento que guia os sonhos e objetivos dos jovens aprendizes.

Tabela 2 - Relação de artigos 2

\begin{tabular}{|c|c|c|c|c|c|}
\hline Título & Autor(ores) & Metodologia & $\begin{array}{l}\text { Universidade } \\
\text { e/ou revista }\end{array}$ & Tipo & Ano \\
\hline $\begin{array}{l}\text { Avaliação do } \\
\text { Programa } \\
\text { Jovem } \\
\text { Aprendiz } \\
\text { a partir de um } \\
\text { Estudo } \\
\text { Quase- } \\
\text { Experimental }\end{array}$ & $\begin{array}{l}\text { Maria da } \\
\text { Conceição } \\
\text { Oliveira Villar; } \\
\text { Luciana } \\
\text { Mourão }\end{array}$ & $\begin{array}{l}\text { Estudo quase } \\
\text { experimental; } \\
\text { quantitativo; } \\
\text { utilizou a Escala } \\
\text { de Percepção } \\
\text { Atual do } \\
\text { Desenvolvimento } \\
\text { Profissional - } \\
\text { EPADP }\end{array}$ & $\begin{array}{c}\text { Universidade } \\
\text { Salgado de } \\
\text { Oliveira - } \\
\text { Niterói - RJ - } \\
\text { Revista } \\
\text { Temas em } \\
\text { Psicologia }\end{array}$ & Artigo & 2018 \\
\hline $\begin{array}{l}\text { Formação } \\
\text { profissional e } \\
\text { futuro: } \\
\text { expectativas } \\
\text { dos } \\
\text { adolescentes } \\
\text { aprendizes }\end{array}$ & $\begin{array}{c}\text { Orlando } \\
\text { Júnior Viana } \\
\text { Macêdo; } \\
\text { Maria de } \\
\text { Fátima } \\
\text { Pereira } \\
\text { Alberto; } \\
\text { Anísio José } \\
\text { da Silva } \\
\text { Araújo }\end{array}$ & $\begin{array}{c}\text { Qualitativa; } \\
\text { entrevistas } \\
\text { semiestruturadas } \\
\text { individuais, } \\
\text { coletivas }\end{array}$ & $\begin{array}{c}\text { Universidade } \\
\text { Federal da } \\
\text { Paraíba - PB } \\
\text { - Revista } \\
\text { Estudos de } \\
\text { Psicologia }\end{array}$ & Artigo & 2012 \\
\hline $\begin{array}{l}\text { O sentido da } \\
\text { formação } \\
\text { profissional no } \\
\text { contexto da } \\
\text { aprendizagem }\end{array}$ & $\begin{array}{c}\text { Orlando } \\
\text { Júnior Viana } \\
\text { Macêdo; } \\
\text { Maria de } \\
\text { Fátima } \\
\text { Pereira } \\
\text { Alberto }\end{array}$ & $\begin{array}{c}\text { Qualitativa; } \\
\text { entrevistas } \\
\text { semiestruturadas } \\
\text { individuais, } \\
\text { coletivas e } \\
\text { análise } \\
\text { documental. }\end{array}$ & $\begin{array}{c}\text { Universidade } \\
\text { Federal da } \\
\text { Paraíba - PB } \\
\text { - Revista } \\
\text { Estudos de } \\
\text { Psicologia }\end{array}$ & Artigo & 2012 \\
\hline
\end{tabular}

Fonte: elaborado pelos autoras.

Os três artigos acima relacionados foram localizados na Plataforma Scielo, com os temas: expectativas dos jovens aprendizes para 0 futuro e contribuição do Programa de Aprendizagem na vivência profissional 
dos aprendizes. Dois artigos tiveram cunho qualitativo, realizaram análise de conteúdo e utilizaram como instrumento metodológico a entrevista semiestruturada, uma delas também recorreu a análise documental, enquanto outro estudo utilizou o método quase experimental de cunho quantitativo e amparou-se no instrumento a Escala de Percepção Atual do Desenvolvimento Profissional - EPADP, uma escala de percepção e desenvolvimento profissional. Os resultados indicam como pontos positivos dos Programas de Aprendizagem: desenvolvimento profissional e empregabilidade; o auxilio os jovens na percepção de si; vontade de continuar os estudos em nível superior; possibilita inserção social e aquisição de bens de consumo. Sob o enfoque negativo, as pesquisas apontam que o Programa não contribui para 0 desenvolvimento do pensamento crítico; não proporciona maior valorização da educação.

Avaliação do Programa Jovem Aprendiz a partir de um Estudo Quase-Experimental. Pretendeu-se avaliar a contribuição do Programa Jovem Aprendiz na vida de jovens de 15 a 18 anos, no que diz respeito ao desenvolvimento profissional, empregabilidade e autoeficácia. Este estudo foi quantitativo. Os resultados demonstraram que o Programa de Aprendizagem possibilita o desenvolvimento profissional, a empregabilidade e a autoeficácia. Concluiu-se também que esse Programa Jovem Aprendiz auxilia, de forma positiva, para que o jovem tenha uma percepção de si, em um curto período.

Formação profissional e futuro: expectativas dos adolescentes aprendizes. Discutiu-se o que os jovens aprendizes têm de expectativas do futuro. As entrevistas demonstraram que os jovens objetivam profissões de nível superior e até de nível médio e que o programa pode auxiliá-los a alcançar essas expectativas através da vivência. $O$ estudo concluiu que, ao mesmo tempo que o Programa possibilita vontade de continuar os estudos até o nível superior, não oferece informações para uma análise crítica, uma vez que esses jovens não demonstraram clareza de que a realização do sonho não depende apenas de esforço pessoal e que o aprimoramento profissional, por uma instituição renomada, não garante futuro.

O sentido da formação profissional no contexto da aprendizagem. Objetivou-se identificar o sentido que os jovens atribuíam ao programa de formação profissional. Os dados demonstraram que a procura do programa se deu mais por perceberem como oportunidade de inserção no mercado de trabalho e para adquirirem renda própria. Em terceiro plano, configurou a aprendizagem. $O$ autor defende a posição de que, através do Programa de Aprendizagem, os indivíduos são ensinados para o mercado e mundo do trabalho. Através dessa pesquisa, ele subentendeu que o programa é visto como inserção social ao mercado e perspectiva de alcance de bens, o que faz com que os jovens não identifiquem a educação, que é uma das principais propostas da formação profissional. 
Tabela 3 - Relação artigos 3

\begin{tabular}{|c|c|c|c|c|c|}
\hline Título & Autor(ores) & Metodologia & $\begin{array}{l}\text { Universidade } \\
\text { e/ou revista }\end{array}$ & Tipo & Ano \\
\hline $\begin{array}{l}\text { O trabalho } \\
\text { juvenil em } \\
\text { perspectiva }\end{array}$ & $\begin{array}{l}\text { Maria Inês } \\
\text { Fontana } \\
\text { Pereira de } \\
\text { Souza; }\end{array}$ & $\begin{array}{c}\text { Qualitativa; } \\
\text { entrevista } \\
\text { semiestruturada }\end{array}$ & $\begin{array}{l}\text { UNESP- } \\
\text { Franca-SP }\end{array}$ & Dissertação & 2001 \\
\hline $\begin{array}{c}\text { Programa de } \\
\text { Aprendizagem: } \\
\text { Desafios e } \\
\text { perspectivas } \\
\text { para o serviço } \\
\text { social }\end{array}$ & $\begin{array}{c}\text { Fernanda } \\
\text { Ferro da Silva; }\end{array}$ & $\begin{array}{c}\text { Qualitativa; } \\
\text { entrevista } \\
\text { semiestruturada }\end{array}$ & $\begin{array}{l}\text { UNESP- } \\
\text { Franca-SP }\end{array}$ & $\begin{array}{l}\text { Trabalho de } \\
\text { Conclusão de } \\
\text { Curso }\end{array}$ & 2011 \\
\hline $\begin{array}{l}\text { O trabalho do } \\
\text { menor aprendiz } \\
\text { no Brasil e a } \\
\text { guarda mirim de } \\
\text { Franca }\end{array}$ & $\begin{array}{l}\text { Patrícia da } \\
\text { Costa Maia; }\end{array}$ & $\begin{array}{c}\text { Qualitativa; } \\
\text { entrevista } \\
\text { semiestruturada }\end{array}$ & $\begin{array}{l}\text { UNESP- } \\
\text { Franca-SP }\end{array}$ & $\begin{array}{l}\text { Trabalho de } \\
\text { Conclusão de } \\
\text { Curso }\end{array}$ & 2004 \\
\hline $\begin{array}{c}\text { Trabalho } \\
\text { aprendiz x } \\
\text { trabalho infantil: } \\
\text { O que os } \\
\text { diferencia? }\end{array}$ & $\begin{array}{l}\text { Talita } \\
\text { Fernanda } \\
\text { Doná; }\end{array}$ & $\begin{array}{c}\text { Qualitativa; } \\
\text { entrevista } \\
\text { semiestruturada } \\
\text { com as } \\
\text { coordenadoras } \\
\text { das instituições } \\
\text { de } \\
\text { Aprendizagem }\end{array}$ & $\begin{array}{l}\text { UNESP- } \\
\text { Franca-SP }\end{array}$ & $\begin{array}{l}\text { Trabalho de } \\
\text { Conclusão de } \\
\text { Curso }\end{array}$ & 2007 \\
\hline $\begin{array}{l}\text { O trabalho } \\
\text { infantil e o } \\
\text { contrato de } \\
\text { aprendizagem }\end{array}$ & $\begin{array}{c}\text { Tatiana } \\
\text { Mascarenhas } \\
\text { Chavier }\end{array}$ & $\begin{array}{l}\text { Qualitativa; } \\
\text { Pesquisa } \\
\text { bibliográfica }\end{array}$ & $\begin{array}{l}\text { UNESP- } \\
\text { Franca-SP }\end{array}$ & $\begin{array}{l}\text { Trabalho de } \\
\text { Conclusão de } \\
\text { Curso }\end{array}$ & 2014 \\
\hline $\begin{array}{l}\text { O trabalho da } \\
\text { criança e do } \\
\text { adolescente: } \\
\text { problema ou } \\
\quad \text { solução }\end{array}$ & $\begin{array}{c}\text { Sheila Batista } \\
\text { Souza }\end{array}$ & $\begin{array}{c}\text { Qualitativa; } \\
\text { entrevista } \\
\text { semiestruturada } \\
\text { com famílias } \\
\text { atendidas pelo } \\
\text { Programa e } \\
\text { com a } \\
\text { assistente } \\
\text { social do } \\
\text { CREAS; três } \\
\text { oficinas com as } \\
\text { famílias e } \\
\text { profissionais; } \\
\text { questionários } \\
\text { pra alunos de } \\
\text { uma escola }\end{array}$ & $\begin{array}{l}\text { UNESP- } \\
\text { Franca-SP }\end{array}$ & $\begin{array}{l}\text { Trabalho de } \\
\text { Conclusão de } \\
\text { Curso }\end{array}$ & 2012 \\
\hline $\begin{array}{l}\text { Aprendizagem } \\
\text { Profissional: } \\
\text { uma alternativa } \\
\text { ao trabalho } \\
\text { infantil } \\
\end{array}$ & $\begin{array}{l}\text { Marina Akemi } \\
\text { Nomoto }\end{array}$ & $\begin{array}{l}\text { Qualitativa; } \\
\text { documental; } \\
\text { entrevista } \\
\text { estruturada }\end{array}$ & $\begin{array}{l}\text { UNESP- } \\
\text { Franca-SP }\end{array}$ & $\begin{array}{l}\text { Trabalho de } \\
\text { Conclusão de } \\
\text { Curso }\end{array}$ & 2004 \\
\hline
\end{tabular}

Fonte: elaborado pelos autoras.

$\mathrm{Na}$ base de dados da Biblioteca da Universidade Estadual Paulista "Júlio de Mesquita Filho" (UNESP) foram encontrados sete trabalhos, acima relacionados, tendo como temas centrais jovem e programas de aprendizagem. Destes sete, somente um se insere na categoria de dissertação de mestrado, os outros cinco são trabalhos de conclusão de curso. Os estudos apresentaram os temas: análise de Programas de Aprendizagem pela perspectiva do jovem aprendiz e também de profissionais que participam dessa política pública; o processo de inserção do adolescente no mundo do trabalho, 
a realidade do trabalho do aprendiz no município de Franca-SP; visão de jovens trabalhadores. A maioria dos trabalhos utilizaram o método exploratório, com revisão de literatura e o uso de entrevistas semiestruturadas como instrumento de coleta de dados. Somente um trabalho utilizou a entrevista estruturada e questionário como instrumento de coleta de dados. Apenas um estudo utilizou como metodologia a pesquisa bibliográfica. Ao contrário das pesquisas anteriores, essas indicam mais as vertentes negativas que positivas dos Programas de aprendizagem. Os poucos aspectos positivos são a inserção no mundo do trabalho e aprimoramento pessoal. As vertentes negativas indicam que os Programas necessitam de fiscalização para evitar a exploração do jovem aprendiz; pouco cuidado e amparo para confirmar a formação para cidadania, correndo o risco de ao invés de incluir gerar exclusão social; falta de respeito pelas empresas em cumprir as leis que regulamentam os Programas de Aprendizagem, a maioria dos jovens não conseguem ser efetivados pelas empregas quanto termina o contrato de aprendizagem; a Aprendizagem Profissional é utilizada de forma equivocada e não cumpre o propósito de relacionar prática e estudo; os jovens aprendizes acham suas vidas mais difíceis que os outros e sentem-se injustiçados em ter que trabalhar e estudar.

O trabalho juvenil em perspectiva. O objetivo do estudo foi analisar como ocorre o processo de inserção no adolescente no mundo do trabalho. A partir dessa pesquisa, as autoras perceberam que, apesar da existência da Lei que rege a política de Aprendizagem Profissional, Lei do Aprendiz, ainda há necessidade de amparo e cuidados para atestar e confirmar a formação de cidadania dos jovens aprendizes, caso isso não ocorra, corre-se o risco de, por conta da vulnerabilidade social desse público, gerar exclusão social.

Programa de Aprendizagem: Desafios e perspectivas para o serviço social. O trabalho teve como objetivo analisar o Programa de Aprendizagem em Comércio de Bens e Serviços na unidade do Senac de Franca -SP e também as diferentes particularidades que demonstram a distinção entre trabalho infantil e o trabalho na condição de aprendiz. A partir dessa análise, as autoras captaram que o fato vai além da existência da Lei da Aprendizagem, os gestores necessitam se ajustar à Lei, os órgãos responsáveis precisam popularizar a propagação da informação sobre a existência da Lei, além de fiscalizar. Além disso, entenderam que, após a inserção dos jovens aprendizes no programa de aprendizagem, foi constatado transformações positivas no caráter profissional, na vida pessoal, em comportamentos e atitudes. O estudo também versou sobre a importância da formação profissional no estímulo de aprimoramento profissional e construção de carreira.

O trabalho do menor aprendiz no Brasil e a guarda mirim de Franca. Buscou-se como objetivo analisar a Guarda Mirim de Franca-SP, 
ressaltando a sua estrutura ao trabalho do jovem aprendiz. A partir do estudo, entendeu-se que é muito relevante utilizar as entidades de aprendizagem como forma de inserir o jovem no mundo do trabalho. Além do que, o contrato especial de aprendizagem se atenta em aliar escola e trabalho dos jovens aprendizes. A pesquisa concluiu então, que o contrato de aprendizagem, se desenvolvido baseado na lei que o regulamenta, beneficia os jovens aprendizes, inserindo-os no mundo do trabalho.

Trabalho aprendiz x trabalho infantil: $O$ que os diferencia? Esta pesquisa objetivou conhecer a realidade concreta do trabalho aprendiz no município de Franca-SP, bem como seu histórico, e focou na diferenciação da compreensão e execução do trabalho infantil e aprendiz. Foi realizada uma pesquisa em três entidades de Franca-SP, com as coordenadoras das instituições. Por meio do estudo, constatou-se que $60 \%$ dos jovens conseguem ser inseridos no mercado como aprendizes e que as empresas não respeitam as Leis, e ao mesmo tempo, percebeu-se ausência de notificação do Ministério do Trabalho. Outro dado relevante que foi levantado é que a maioria das empresas não tem efetivado os aprendizes como funcionários, gerando desmotivação e obrigando-os a voltar ao ciclo do desemprego.

O trabalho infantil e o contrato de aprendizagem. Analisou-se as implicações do trabalho na infância e adolescência no desenvolvimento físico e psíquico do jovem. A pesquisa concluiu que crianças e adolescentes são afetados ao se inserirem no mundo do trabalho de maneira precoce. A Lei da Aprendizagem foi citada como forma de erradicação ao trabalho infantil. Contudo, evidencia a necessidade da visão dos atores sociais da política pública referente a essa lei para prevenir danos no que diz respeito à exploração do adolescente, ou que a Aprendizagem Profissional é utilizada de forma equivocada e não cumpre seu propósito de relacionar prática e estudo dos jovens.

O trabalho da criança e do adolescente: problema ou solução. Discutiu-se acerca da visão dos adolescentes trabalhadores. Foram realizadas entrevistas semiestruturadas com 100 famílias de crianças e adolescentes atendidas pelo PETI (Programa de Erradicação do Trabalho Infantil) moradoras de um bairro de Franca - SP, três oficinas com famílias atendidas pelo Programa, três oficinas com profissionais envolvidos com esse projeto e uma entrevista com uma assistente social do CREAS, além de aplicar questionário para 114 alunos de uma escola situada no mesmo bairro das famílias que participaram das oficinas. O projeto constatou que ocorre o trabalho infantil em trabalhos informais, principalmente em fabricação de calçado em domicílio. Através disso, fica claro que o trabalho infantil e do adolescente é utilizado para complemento da renda, podendo acarretar em prejuízos no desenvolvimento e na educação. 
Aprendizagem Profissional: uma alternativa ao trabalho infantil. 0 estudo teve como objetivo estudar o tema da aprendizagem profissional de um Programa de Aprendizagem de Ribeirão Preto - SP, analisando se ele teve contribuição para jovens aprendizes. As autoras demonstraram que esse Programa de Aprendizagem tem representatividade positiva na vida dos jovens aprendizes que nele estão inseridos, mas alguns jovens ainda relatam que acham sua adolescência mais difícil que a de outros, sentindo-se injustiçados com relação a outros adolescentes que não precisam trabalhar.

Tabela 4 - Análise temática: Assuntos que mais aparecem nas considerações dos trabalhos apresentados nas plataformas.

\begin{tabular}{|c|c|}
\hline Categoria & Subcategoria \\
\hline \multirow[t]{2}{*}{$\begin{array}{l}\text { Contribuição dos } \text { Programas de } \\
\text { Aprendizagens }\end{array}$} & $\begin{array}{l}\text { Contribuições positivas no desenvolvimento pessoal e } \\
\text { profissional dos jovens aprendizes; }\end{array}$ \\
\hline & Necessidade de fiscalização da Lei da Aprendizagem; \\
\hline Relação Estudo e Trabalho & $\begin{array}{l}\text { Conciliar trabalho e estudo se configura como desafio } \\
\text { na rotina dos jovens aprendizes; }\end{array}$ \\
\hline
\end{tabular}

As categorias e subcategorias possibilitam realizar uma análise mais aprofundada dos estudos encontrados. Como exposto anteriormente, a Política Pública de Aprendizagem Profissional foi criada baseada na Lei Federal 10.097/2000 (BRASIL, 2000), normatizada pelo Decreto $n=5.598$, de $1^{\circ}$ de dezembro de 2005, que obriga aprendizes a serem contratados pelas empresas e, ao mesmo tempo, essas empresas devem cadastrar os aprendizes em instituições que realizam curso teórico para esses jovens, denominado Programa de Aprendizagem. A partir de uma leitura mais analítica dos estudos localizados, pode-se perceber que a maioria deles demonstram que os Programas de Aprendizagem têm contribuição positiva no que diz respeito ao desenvolvimento pessoal e profissional, despertando iniciativa de aprimoramento profissional e capacitação dos jovens inseridos nesses Programas. Corroborando com essa afirmação, Souza et.al. (2016) cita os efeitos positivos dos Programas de Aprendizagem como amadurecimento pessoal e profissional, boas oportunidades, responsabilidades, independência financeira, crescimento profissional, realização pessoal, novos aprendizados, experiência profissional e formação profissional.

Os estudos de Maia (2004), Doná (2007), Chavier (2014) e Souza (2011), selecionados na plataforma da Biblioteca da Universidade Estadual Paulista de Franca-SP, evidenciam a relevância de fiscalizar a Lei da Aprendizagem através dos atores sociais, como por exemplo, o Ministério do Trabalho. Essas pesquisas defendem que é necessário realizar constantes visitas técnicas nas instituições que oferecem o Programa de Aprendizagem e também nas empresas que os jovens estão inseridos como aprendizes, com o objetivo de fiscalizar teoria e prática desses jovens, buscando prevenir danos 
no que se diz respeito à exploração do jovem. Além disso, certificar que a Aprendizagem Profissional está sendo realizada na forma que a lei regulamenta, relacionando prática e estudos dos jovens aprendizes. Quando a Lei não é fiscalizada, corre-se o risco de, ao invés da Política de Aprendizagem Profissional cumprir o seu principal objetivo, que é inserir o jovem no mundo do trabalho, desenvolva-se outro problema social, criando condições para 0 trabalho infantil.

Ao refletir acerca de tal situação, é importante pensar sobre a relevância do controle social das Políticas Públicas, Serafim e Teixeira (2008) dizem que é muito importante a participação da sociedade para a garantia de que as políticas acolham as urgências dos indivíduos, melhorando os serviços oferecidos no que tange a qualidade. A participação da sociedade nesse sentido possibilita que a política pública se fortaleça, adequando-as quanto as necessidades da população. Isso está totalmente relacionado com a fiscalização da Lei da Aprendizagem, realizando o controle social permanente na Política de Aprendizagem Social, sendo uma forma de evitar que os direitos dos jovens aprendizes quanto a estudo, trabalho e condições trabalhistas não sejam garantidos.

Outro ponto importante para analisar nas pesquisas encontradas, é a relação entre trabalho e estudo, apresentados pelas pesquisas de Lizote, et. al. (2015), Pessoa e Alberto (2015), Moreira e Trindade (2013), Mattos e Chaves (2006), Mattos e Chaves (2010). Essas pesquisas expõem que, ao mesmo tempo que o Programa de Aprendizagem contribui para 0 desenvolvimento pessoal e profissional do jovem aprendiz, obriga -os a se planejarem em uma rotina muitas vezes apertada de estudo e trabalho, o que pode deixá-los em desvantagem em relação àqueles jovens que só trabalham ou que só estudam, os autores defenderam que alguns jovens acham sua adolescência mais difícil que a de outros, sentindo-se injustiçados com relação a outros adolescentes que não precisam trabalhar. Esse dado corrobora o que Esteves e Abramovay (2009) mostram sobre não existir apenas um tipo de juventude, uma vez que existem diferentes possibilidades, impedimentos e influências na sociedade, o que faz com que reflita na existência de diferentes grupos juvenis. Enquanto os jovens de classe social mais alta se inserem mais tardiamente no mundo trabalho, os de classe social mais baixa precisam iniciar essa fase de responsabilidades mais cedo, muitas vezes deixando de viver a condição juvenil em sua plenitude para se dedicar ao estudo e ao trabalho.

Ainda sobre a relação entre estudo e trabalho Thomé, Pereira e Coller (2016, p.107) expõem que a "[...] dupla jornada escola/trabalho pode ser desgastante para os jovens, fazendo com que o seu rendimento acadêmico decline, ocorrendo, assim, repetências escolares, que podem acarretar em desmotivação e evasão escolar [..]". Lisboa (2010) diz que equiparar emprego e estudo é um obstáculo, bem como faz uma ponte dessa questão com a 
evasão escolar, afirmando que é uma ação comum em jovens de classe social mais baixa, por isso, tem-se mais um fator que justifica a necessidade da aprendizagem profissional, a qual, por lei, exige que, além de trabalhar, 0 jovem deve estar matriculado regularmente na escola e frequentar os estudos. Sabendo que a juventude é um período de desenvolvimento psíquico, emocional e social, e representa uma fase de aquisição de conhecimento, é importante equiparar a relação estudo/trabalho, para que principalmente o estudo não seja prejudicado.

\section{CONSIDERAÇÕES FINAIS}

Apreendemos que os resultados da pesquisa intitulada: Juventude e os programas de aprendizagens: o que dizem as pesquisas? demonstram a relevância da temática enquanto objeto de pesquisa, evidenciando a necessidade de futuras pesquisas mais aprofundadas.

Percebemos por esta pesquisa que o tema juventude, estudo e trabalho é cada vez mais objeto de investigação em pesquisas na área das ciências humanas e sociais, que mostram que o trabalho é uma forma de inserção social.

Da análise final do presente trabalho, os dados científicos coletados foram submetidos a uma comparação entre seus principais pontos: objetivos, metodologia e resultados encontrados. Após um exame minucioso de cada categoria, deve-se reiterar que o Programa de Aprendizagem é considerado por opinião da maioria dos autores como forma de contribuição para inserir o jovem no mundo do trabalho e para o desenvolvimento de habilidades pessoais e profissionais.

Em contrapartida, foi constatado em algumas pesquisas selecionadas que muitas crianças e adolescentes moradoras de bairros periféricos no município de Franca-SP ainda realizam trabalho infantil em atividades informais e que, além disso, esse tipo de trabalho é utilizado, muitas vezes, para auxilio na manutenção básica das famílias. Isso é comum também no jovem aprendiz, como evidenciam os estudos, visto que um dos motivos que os impulsionam à vontade de trabalhar está relacionado ao complemento da renda familiar.

Muitos jovens inseridos nos Programa de Aprendizagem visualizam essa Política Pública como forma de inserção no mundo do trabalho e de aquisição de renda. Algumas vezes, o estudo não é visto na perspectiva deles como objetivo principal. É um dado preocupante, uma vez que mostra que, na relação estudo e trabalho, o trabalho é visto como primeiro objetivo dos jovens, não priorizando os estudos que podem possibilitar o acesso à melhores 
empregos e salários, além da aquisição de capacidade crítica para fazer uma "leitura" do mundo em que vivem.

Ao mesmo tempo em que, na perspectiva dos jovens, o Programa de Aprendizagem é visto como forma de inserção no mundo do trabalho e aquisição de renda, os dados explanam que essa política de Aprendizagem Profissional possibilita ao jovem a percepção de suas habilidades sociais em um curto espaço de tempo e que, além disso, contribui nas orientações profissionais do jovem, bem como influencia alguns a cursarem o ensino superior e continuarem o aprimoramento profissional.

Entendemos que as respostas dos aprendizes nas entrevistas são muito favoráveis ao desenvolvimento do programa, que essa política tem representatividade positiva na vida dos jovens aprendizes. Mas, ao mesmo tempo, as pesquisas mostram que é necessário realizar trabalho contínuo com esse público sobre a importância da aprendizagem e do incentivo ao planejamento entre estudo e trabalho.

Também é possível concluir que é essencial o acompanhamento e fiscalização de políticas públicas para certificar se o objetivo principal está sendo alcançado. Com a política de Aprendizagem Profissional não é diferente, é necessária fiscalização para verificar se as empresas cumprem as leis na contratação de jovens aprendizes e para averiguar se estão garantindo que a relação trabalho e estudo dos jovens aprendizes seja respeitada tanto pelas empresas quanto pelos Programas de Aprendizagem.

De forma geral, considera-se que os Programas de Aprendizagem cumprem seu papel de inserir o jovem no mercado de trabalho, proporcionando possibilidades de desenvolvimento pessoal, de sonhos e objetivos e que devem ser respeitados como sujeitos de direitos em contínuo desenvolvimento pessoal e profissional, uma vez que buscam, por meio do estudo e do trabalho, encontrar sentido para vida e construir a própria identidade.

\section{REFERÊNCIAS}

BRASIL. Estatuto da Criança e do Adolescente: Lei federal no 8069, de 13 de julho de 1990. São Paulo: Governo do Estado de São Paulo, [2017]. Disponível em: <http://www.chegadetrabalhoinfantil.org.br/wpcontent/uploads/2017/06/LivroECA_2017_v05_INTERNET.pdf>. Acesso em: 01 out. 2018.

Estatuto da Juventude: Lei federal no 12.852, de 5 de agosto de 2013. Brasília: Casa Civil, [2013]. Disponível em:

http://www.planalto.gov.br/CCIVIL_03/_Ato2011-2014/2013/Lei/L12852.htm. Acesso em: 18 jul. 2019. 
. Guia de Políticas Públicas de Juventude. Brasília: Secretaria-Geral da Presidência da República, [2006]. Disponível em: $<$ http://bibjuventude.ibict.br/jspui/bitstream/192/117/1/guiajuventude1.pdf>. Acesso em: 12. ago.2019

Lei $\mathbf{n}$. 10.097, de 19 de dezembro de 2000. Altera dispositivos da Consolidação das Leis do Trabalho - CLT. Brasília: Casa Civil, [1979]. Disponível em: http://www.planalto.gov.br/ccivil_03/leis/10097.htm. Acesso em: 12 ago. 2019 .

CHAVIER, T. M. O trabalho infantil e o contrato de aprendizagem. 2014, 57f. (Monografia em Direito). Universidade Estadual Paulista, Franca, 2019.

DAYRELL, J. O jovem como sujeito social. In: FÁVERO, F., et. al. (Orgs). Juventude e contemporaneidade. Brasília: UNESCO, MEC, ANPEd, p. 155176, 2007.

DONÁ, T. F. Trabalho aprendiz $x$ trabalho infantil: 0 que os diferencia?, 2007. (Monografia em Serviço Social). Universidade Estadual Paulista, Franca, 2019.

ESTEVES, L. C. G.; ABRAMOVAY, M. Juventude, Juventudes: uma análise do trabalho e renda da juventude brasileira. In: ABRAMOVAY, M.; ANDRADE, E. R. e ESTEVES, L. C. G. (Orgs). Juventudes: outros olhares sobre a diversidade. Brasília: Ministério da Educação, Secretaria de Educação Continuada, Alfabetização e Diversidade, Unesco, p. 21-56, 2009.

FERREIRA, N. S. A. As pesquisas denominadas "estado da arte". Educação e Sociedade. São Paulo, v. 23, n. 79, p. 257-272, 2002.

GONÇALVES A. L. A. Aprendizagem profissional: trabalho e desenvolvimento social e econômico. Estudos Avançados. Brasília, v.28, n.81, p.191-200, 2014.

LEON, A. L. P. Juventude, Juventudes: uma análise do trabalho e renda da juventude brasileira. ABRAMOVAY, M.; ANDRADE, E. R. e ESTEVES, L. C. G. (Orgs). Juventudes: outros olhares sobre a diversidade. Brasília: Ministério da Educação, Secretaria de Educação Continuada, Alfabetização e Diversidade, Unesco, p. 271 - 322, 2009.

LISBOA, M. D. O desemprego na juventude: um estudo sobre o sentido do desemprego para jovens que residem em cidades de sub-regiões produtivas da indústria do calçado, na região Sudeste do país (Pesquisa de PósDoutorado). São Paulo: FAPESP, 2010. Disponível em:

$<$ http://educere.bruc.com.br/arquivo/pdf2015/16385 10730.pdf >. Acesso em: 05. ago.2019. 
LIZOTE, et.al. Programa de aprendizagem: imagem e satisfação na visão dos aprendizes. Revista de Administração, Contabilidade e Economia (RACE). Joaçaba, v.14, n.3, 2015.

MAIA, P. C. O trabalho do menor aprendiz no Brasil e a guarda mirim de Franca, 2004. (Monografia em Direito). Universidade Estadual Paulista, Franca, 2019.

MATTOS, E; CHAVES, A. M. As representações sociais do trabalho entre adolescentes aprendizes - um estudo piloto. Revista Brasileira Crescimento e Desenvolvimento Humano. Salvador, v. 16, n.3, p.66-75, 2006.

MATTOS, E; CHAVES, A. M. Trabalho e escola: é possível conciliar? A perspectiva de jovens aprendizes baianos. Psicologia Ciência e Profissão. Brasília, v.30, n.3, p.540-555, 2010.

MOREIRA SILVA, R. D. ; TRINDADE, Z. A. Adolescentes aprendizes: aspectos da inserção profissional e mudanças na percepção de si. Revista Brasileira de Orientação Profissional, v.14, n.1, p.73-86, 2013.

NOVAES, R. Os jovens de hoje: contextos, diferenças e trajetórias. IN: AMEIDA, M. I. M. de; EUGENIO, F. (Orgs). Culturas Jovens. Rio de Janeiro: Jorge Zahar, 2006. Cap. 2, p. 105-119.

PESSOA, M. C. B.; Alberto, M. F. P. Formação profissional: as vivências dos jovens em um programa de aprendizagem. Revista Estudos Interdisciplinares em Psicologia. Londrina, v.6, p.02-20, 2015.

RAVASCO A. A.; MAIA M.; MANCEBO D. Juventude, trabalho e projetos de Vida: ninguém pode ficar parado. Psicologia Ciência e Profissão. Rio de Janeiro, v.30, n.2, p.376-389, 2010.

SERAFIM, L.; TEIXEIRA, A. C. Controle social das políticas públicas. 2008.

SOUZA, D. A. A, et. al. Percepção dos jovens aprendizes sobre o trabalho que exercem. 2016. Disponível em: <https://www.aedb.br/seget/arquivos/artigos17/12425153.pdf> Acesso em: 12. ago.

SOUZA, M. I F. P. O trabalho juvenil em perspectiva, 2001, $204 \mathrm{f}$. (Dissertação em Serviço Social). Universidade Estadual Paulista, Franca, 2019.

THOMÉ-DUTRA, L, PEREIRA, A. S.; KOLLER, S. H. O desafio de conciliar trabalho e escola: características sociodemográficas de jovens trabalhadores e não-trabalhadores. Psicologia: Teoria e Pesquisa. Porto Alegre, v.32, n.1, p. 101-109, 2016. 


\title{
NOVO OLHAR NO PAPEL DO SERVIÇO SOCIAL NA SAÚDE: A educação interprofissional
}

\author{
BORGES, Cintia Ceosane de Paula \\ Discente - UEMG \\ CAMARGO, Carmen Aparecida Cardoso Maia \\ Docente - UEMG \\ MARINHO, Isabella de Paula \\ Discente - UEMG
}

\section{INTRODUÇÃO}

Este artigo propõe uma reflexão sobre um novo conceito e um quadro de referência que deve permitir o desenvolvimento de uma melhor compreensão de um fenômeno, que é o desenvolvimento de uma prática de cuidados de saúde coesa e integrada entre os profissionais, em resposta às necessidades dos cuidados básicos em saúde, que é o trabalho interprofissional. Tem por objetivo refletir sobre as possiblidades que a interprofissionalidade pode trazer às diferentes profissões, dentro de uma instituição de saúde, com ênfase no serviço social.

A educação interprofissional e a colaboração interprofissional não têm frequentemente encontrado um lugar na educação e nas práticas dos profissionais de saúde. A interprofissionalidade diz respeito aos processos e determinantes que influenciam às iniciativas de educação interprofissional, bem como aos determinantes e processos inerentes à colaboração interprofissional.

No domínio da saúde, a interprofissionalidade é uma resposta às realidades das práticas de saúde fragmentadas. Os profissionais são oriundos de diferentes disciplinas e organizações de assistência médica, cada qual apresentando conceituações distintas do paciente, das necessidades e do tipo de resposta necessária para abordar as numerosas e complexas situações de cuidado com a saúde do usuário.

A Educação Interprofissional (EIP) vem se constituindo como importante debate e discussão em todo o mundo; e esse artigo tem a intenção de examinar suas bases teórico-conceituais e metodológicas, discutindo suas potencialidades na formação de profissionais, mais aptos ao efetivo trabalho em equipe, bem como problematizando desafios importantes para 0 fortalecimento dessa abordagem na atual lógica de formação profissional em saúde. 
A interprofissionalidade advém da preocupação dos profissionais em conciliar suas particularidades e perspectivas, sendo necessária a interação contínua e o compartilhamento de conhecimentos entre esses, resolvendo ou explorando uma variedade de questões educacionais e assistenciais, a fim de otimizar a participação do paciente.

A temática da formação de profissionais de saúde na perspectiva da interprofissionalidade acompanha o debate sobre as mudanças nas diretrizes curriculares na educação superior há alguns anos. No Brasil, com os debates sobre a integralidade em saúde, em particular com a Reforma Sanitária, mobilizou-se fortemente a formação e o trabalho na saúde, buscando a integralidade, e, assim, no contexto atual, a interprofissionalidade.

O conceito de educação interprofissional em saúde, de acordo com Souto, Batista e Batista (2014), o Center for the Advancement of Interprofessional Education (CAIPE, Londres), se realiza no momento em que uma ou mais profissões aprendem "com, para e sobre cada uma", com a finalidade de melhorar a comunicação, a colaboração interprofissional e, como consequência, a qualidade do cuidado.

As autoras acima, citando Levison (2003), enfatizam que na área da formação em saúde a educação interprofissional é vista como um componente crucial, não só pela proposta de aprendizagem compartilhada, mas também por ser disparador de novos tipos de trabalho e de novas formas de subjetivação dos papéis profissionais, uma vez que reorganiza os fluxos de tarefas e responsabilidades no contexto da equipe interprofissional.

Nos dias atuais, surgem outras definições, sempre buscando esclarecer os aspectos centrais dessa abordagem e sua potência para o fortalecimento do trabalho em saúde, marcado pela efetiva interação entre os diferentes profissionais. Uma definição mais recente, produto de uma revisão sistemática, afirma que a educação interprofissional em saúde ocorre quando os membros de mais de uma profissão da saúde aprendem em conjunto, de forma interativa, com o propósito explícito de melhorar a colaboração interprofissional ou a saúde/bem-estar dos usuários (PEDUZZI et al., 2018).

De acordo com o conceito é possível afirmar que o horizonte da educação interprofissional é o desenvolvimento de profissionais de saúde mais colaborativos, capazes de prestar uma assistência mais integral, e, consequentemente, mais coerente na resolução e no enfrentamento dos problemas e das necessidades de saúde. A colaboração torna-se a prática esperada entre os diferentes profissionais de saúde, implicando em outras importantes mudanças (PEDUZZI et al., 2018).

$\mathrm{Na}$ reflexão sobre o trabalho dos assistentes sociais é relevante destacar que esses profissionais atuam nas manifestações da questão social e 
no modo como elas interagem com a política social, "mediação incontornável na constituição do trabalho profissional” (IAMAMOTO, 2008, p. 185).

Dentre as diversas complexidades da realidade social, que imbricam a formação e o trabalho profissional do assistente social, e, considerando as diversas áreas de atuação, prioriza-se, neste estudo, àquelas relacionadas ao trabalho na área da saúde.

No que se refere à saúde, Bravo e Matos (2009) salienta que este é um dos setores mais significativos na atuação do Serviço Social, tendo concentrado historicamente um grande quantitativo de profissionais, situação que permanece até os dias correntes.

A interprofissionalidade requer uma mudança de paradigma, uma vez que a prática interprofissional tem características únicas em termos de valores, códigos de conduta e formas de trabalho.

Assim, para a desenvoltura das reflexões aqui apresentadas, o artigo foi dividido em dois momentos: no primeiro, apresenta-se elementos universais, que possibilitam a reflexão sobre a educação interprofissional, e, no segundo, a inserção do profissional do Serviço Social nos serviços de saúde, dentro do contexto da educação interprofissional e de práticas colaborativas.

\section{METODOLOGIA}

Trata-se de uma pesquisa descritiva-reflexiva, de cunho bibliográfica, cuja metodologia utilizada foi a busca por trabalhos científicos publicadas em revistas científicas nacionais de 2009 até 2019. Para isso, foram-se pesquisados artigos nos bancos de dados do SciELO e do Google Acadêmico, que tinham como foco a interprofissionalidade; utilizou-se as palavras chave interprofissionalidade, educação interprofissional na saúde e serviço social na saúde.

O estudo foi realizado no mês de abril e maio de 2019, utilizando as bases de dados do Scientific Eletronic Library Online (Scielo). Para o levantamento bibliográfico utilizou-se os descritores interprofissionalidade, educação interprofissional na saúde e serviço social na saúde. Foram encontrados vinte artigos e, desses, dez trouxeram experiências de práticas de interprofissionalidade e Serviço Social na saúde.

Os critérios de inclusão foram artigos no idioma português, dos últimos dez anos, completos. Quanto aos critérios de exclusão, artigos cujo conteúdo não abordavam o assunto proposto.

Dentre os 20 trabalhos analisados, dez trouxeram experiências de práticas do tema proposto. Após compilação dos artigos que se enquadraram nesses critérios, foi realizada a leitura deles e, posteriormente, uma análise de conteúdo temática (Bardin, 2002), buscando a compreensão crítica das 
comunicações e de suas significações. Foi realizada análise de conteúdo dos artigos e identificados dois temas: "interprofissionalidade: rompendo barreiras da hierarquização das profissões" e "Serviço Social e a sade".

\section{RESULTADOS E DISCUSSÃO}

3.1 Interprofissionalidade: rompendo barreiras da hierarquização das profissões

A Educação Interprofissional em Saúde (EIP) consiste em ocasiões nas quais membros de duas ou mais profissões aprendam juntos, de forma interativa, com o propósito explícito de avançar na perspectiva da colaboração, como prerrogativa para a melhoria na qualidade da atenção à saúde. A EIP possui relevância no desenvolvimento de competências colaborativas, como pilares para o efetivo trabalho em equipe na produção dos serviços de saúde e na promoção do cuidado.

De acordo com Araujo et al (2017), a Organização Mundial da Saúde (OMS) propôs a definição para a EIP: "É quando estudantes ou profissionais de dois ou mais cursos, ou núcleos profissionais, aprendem sobre os outros, com os outros e entre si". A EIP constitui uma estratégia que oportuniza o desenvolvimento do trabalho coletivo efetivo, com o intento de otimizar a qualidade da atenção à saúde.

Os autores supracitados, enfatizam que

Fortalecer a EIP favorece a implementação da prática colaborativa em saúde, uma vez que esta pressupõe a incorporação da experiência de profissionais de diversos núcleos do saber, estimulando a comunicação entre eles e a tomada de decisão, com vistas a consolidar a integralidade do cuidado. Destaca-se, ainda, a importância do envolvimento de diferentes atores no processo, para além dos profissionais da área, o que amplia o escopo de atuação destes e as conquistas dos objetivos de saúde.

Portanto, o desenvolvimento da educação interprofissional implica uma melhor compreensão dos determinantes e processos que influenciam a educação interprofissional e a prática interprofissional. Envolve também a compreensão das ligações entre essas duas esferas de atividade.

Escalda et al.(2018), citando (PEDUZZl et al., 2013) acrescenta que

Diferentes autores têm enfatizado que a prática colaborativa é fortemente induzida quando os profissionais são formados nos termos de uma educação interprofissional (EIP). Conceitualmente, a EIP concretiza-se na medida em que duas ou mais profissões são aprendidas de forma cooperada sobre, para e com o outro a melhorar o cuidado e a atenção à saúde, implicando tanto o trabalho em conjunto com pacientes, usuários, seus familiares e cuidadores e as comunidades (WORL HEALTH ORGANIZATION, 2010; BARR, 2005; BARR; LOW, 2012; MCPHERSON; HEADRICK; MOSS, 2001; 
HAMMICK et al., 2008) quanto uma aprendizagem marcadamente interativa, que coloca, no centro da formação (ou qualificação profissional), o conhecimento necessário sobre competências, papéis e conhecimentos das diferentes profissionais.

Ou seja, uma visão integrada, de diferentes autores, em que diferentes profissões trabalhem juntas. No entanto, a despeito da adoção da EIP na formação profissional, o trabalho colaborativo apresenta muitos desafios, principalmente na formação do profissional da Saúde.

De acordo com Ely e Toassi (2018), as inovações impulsionadas pelas políticas públicas, além de promoverem maior aproximação entre universidade e o contexto do SUS, também fomentaram a necessidade de integração entre os cursos da saúde. Somado a isso, a compreensão da integralidade da atenção como eixo central do trabalho e do ensino na saúde coloca o trabalho interdisciplinar e interprofissional como uma necessidade fundamental no processo de formação em saúde.

Nesse contexto, Ely e Toassi (2018), citando alguns autores, argumentam que

\begin{abstract}
Propostas curriculares inovadoras, integradas, começam a se destacar no país (BRAID; MACHADO; ARANHA, 2012), trazendo para a pauta de discussões a necessidade de uma formação em saúde que transcenda os fazeres individualizados de cada profissão. Assume-se, assim, a importância do trabalho em equipe e da compreensão contextualizada e ampla dos processos de saúdedoença.
\end{abstract}

De acordo com Eli e Toassi (2018), a integração ensino-serviço, pode ser definida como o trabalho coletivo pactuado entre estudantes, docentes e trabalhadores do campo de práticas em prol da qualidade da atenção às necessidades de saúde dos usuários, qualidade da formação e satisfação dos usuários e dos trabalhadores do serviço, que pode ter como desdobramento o enfoque no ensino, no serviço, na gestão setorial, no controle social e respeito aos usuários.

Segundo os autores, a fragmentação entre os saberes merece especial atenção, dada a possibilidade de melhora na formação em saúde com sua inclusão na elaboração das propostas de ensino prático. A desarticulação entre o docente e os serviços da saúde pode desencadear conflitos expressos em um processo de divisão do trabalho, no qual o docente responsabiliza-se pela coordenação do ensino, ou seja, a parte mais intelectual da formação, enquanto o trabalhador do campo realizará o trabalho operacional ao qual é atribuído menos prestígio.

Assim sendo, a estrutura fragmentada das universidades reforça a ênfase na especialização do saber técnico-profissional, dificultando a articulação entre os cursos de graduação. 
Por meio da Educação Interprofissional, propomos uma visão integrada de um conjunto de fatores derivados das estruturas que influenciam a interprofissionalidade e os processos colaborativos que permitirão com que educadores e profissionais de diferentes profissões trabalhem juntos.

\subsection{Serviço Social e a saúde}

De acordo com lamamoto e Carvalho (2011), o serviço social nasceu no bojo da sociedade capitalista, na década de 1930, expressando o controle do Estado interventor com as reivindicações da classe trabalhadora por melhores condições de trabalho e de vida. O processo de acumulação do capital aumentava desenfreadamente e manifestava-se materialmente na vida dos sujeitos. Isso resultava no alargamento da questão social já inserida no seio da sociedade. Com a exploração do trabalho e os baixos salários, os proletariados encontravam-se em meio a precárias condições de vida, caracterizando moradias insalubres e a ausência do que se configura enquanto básico para subsistência dos indivíduos, como água, luz e esgoto.

Nesse contexto, o Serviço Social volta as suas ações para o enfrentamento das expressões latentes da questão social, que adoecem a sociedade até os dias atuais, devido à busca pela acumulação do capital e riqueza socialmente construída, mas desigualmente distribuída. Desse modo, em meio à intervenção do Estado e às reivindicações da classe trabalhadora, entra para o debate a Política de Saúde Pública e a conquista do SUS, atualmente inserida no processo contraditório de um Estado norteado por uma política de ajuste neoliberal que, segundo Bravo (2009) se estabelece enquanto mínimo de direitos, contencionista, e tem como base o privilegiamento do modelo privado de saúde.

Nesse sentido, com base em Costa (2009), o assistente social atua na perspectiva da garantia dos direitos, na viabilização de condições que fomentem a promoção da saúde e o acesso aos serviços de saúde, o que se torna matéria-prima do exercício profissional na saúde em implicação ao fortalecimento da saúde pública universal. $O$ assistente social se insere objetivando sua atuação na mediação do que diz respeito ao processo de desvelamento das questões que permeiam a relação saúde-doença.

A inserção do Serviço Social nos serviços de saúde se deu por meio de uma busca de construção do exercício profissional a partir do modelo médico clínico. Assim, o Assistente Social foi identificado, em conjunto com outros profissionais, como aquele que podia contribuir para o aperfeiçoamento do trabalho do médico.

Para Ely e Toassi (2018), o trabalho do assistente social na saúde deve ter como eixo central a busca criativa e incessante da incorporação 
destes conhecimentos, articulados aos princípios do projeto de Reforma Sanitária e pelo Projeto Ético-Político do Serviço Social.

$\mathrm{Na}$ atualidade é exigido do profissional um contínuo processo de conhecimentos através de pesquisas e intervenção profissional competente, vigorosa e crítica, baseada na Política Nacional de Saúde e no Projeto Ético Político do Serviço Social, o que é considerado um desafio, assegurando ao cidadão uma prática humana e humanizadora, na qual o valor humano, a qualidade de vida e a dignidade da morte, no caso dos pacientes fora de possibilidades terapêuticas, sejam alicerces construídos e objetivos comuns para toda a equipe.

O Assistente Social, baseado em sua fundamentação teórica e prática, supera os obstáculos apresentados no contexto atual, considerando atividades e métodos para garantir direitos e melhores condições de vida aos pacientes.

Segundo lamamoto (2008) a organização social capitalista insere diversas armadilhas no cotidiano profissional, que devem ser objetos de atenção. E é com essa perspectiva que o Assistente Social deve enxergar as contradições postas no seu cotidiano profissional.

Uma das armadilhas e desafio que se observa na atuação do profissional do Serviço Social é em relação à fragmentação existente entre as profissões de saúde e as demandas apresentadas, pois é possível notar que existe grande dificuldade de dialogar com a equipe de saúde para esclarecer suas atribuições e competências, porém essas dificuldades devem impulsionar a realização de reuniões e debates entre os diversos profissionais para o esclarecimento de suas ações e estabelecimento de rotinas e planos de trabalho (CFESS, 2009).

O CFESS destaca como ações de articulação dos assistentes sociais na equipe de saúde:

-Esclarecer as suas atribuições e competências, elaborando junto com a equipe propostas de trabalho que delimitem as ações dos diversos profissionais, através da realização de seminários, debates, grupos de estudos e encontros;

-Elaborar, também em conjunto à equipe de saúde, a organização e a realização de treinamentos e a capacitação do pessoal técnicoadministrativo, com vistas a qualificar as ações administrativas, que têm interface com o atendimento ao usuário, tais como a marcação de exames e consultas e a convocação da família e/ou responsável nas situações de alta e óbito;

-Incentivar e participar junto com os demais profissionais de saúde da discussão do modelo assistencial e da elaboração de normas, rotinas e da oferta de atendimento, assegurando como base os interesses e as 
demandas da população usuária. Isso, exige o rompimento com o modelo assistencial, baseado na procura espontânea e no tratamento isolado das doenças;

- Criar, junto com a equipe, uma rotina que assegure a inserção do Serviço Social no processo de admissão, internação e alta hospitalar no sentido de, desde a entrada do usuário/família na unidade, identificar e trabalhar os aspectos sociais da situação apresentada e garantir a participação dos mesmos no processo de reabilitação, bem como a plena informação de sua situação de saúde e a discussão sobre as suas reais necessidades e possibilidades de recuperação, face às suas condições de vida;

-Realizar, em conjunto com o médico, o atendimento à família e/ou responsáveis em caso de óbito, tendo como participante o assistente social, em relação ao apoio necessário para o enfrentamento da questão e, principalmente, a fim de esclarecer a respeito dos benefícios e direitos referentes à situação, previstos no aparato normativo e legal vigente, tais como os relacionados à previdência social, ao mundo do trabalho (licença) e aos seguros sociais (DPVAT), bem como informações sobre sepultamento gratuito, traslado (relação a usuários de outras localidades), entre outras garantias de direitos; e participação em conjunto com a equipe de saúde, de ações socioeducativas nos diversos programas e clínicas, como por exemplo, no planejamento familiar, na saúde da família, na saúde da mulher, da criança e do idoso, na saúde do trabalhador, nas doenças infectocontagiosas (DST/AIDS, tuberculose, hanseníase, entre outras) e nas situações de violência sexual e doméstica;

-Planejar, executar e avaliar com a equipe de saúde ações que assegurem a saúde enquanto direito;

-Sensibilizar o usuário e/ou sua família para participar do tratamento de saúde proposto pela equipe;

-Participar do projeto de humanização da unidade de saúde na sua concepção ampliada, sendo transversal a todo $o$ atendimento da unidade $e$ não restrito à porta da entrada, tendo como referência o projeto de Reforma Sanitária;

-Realizar a notificação, frente a uma situação constatada e/ou suspeita de violência aos segmentos já explicitados às autoridades competentes, assim como a verificação das providencias cabíveis (CFESS 2009. p.31).

Um dos limites observados, também na atuação do assistente social na área da saúde, é a forte presença da perspectiva conservadora que se manifesta na descrença da Saúde enquanto política pública universal, na necessidade da construção de um saber específico e fragmentado, a exemplo da prática médica, na auto representação dos assistentes sociais enquanto 
sanitaristas após realizarem a formação em saúde pública, e na intervenção fenomenológica denominada Serviço Social Clínico (CFESS, 2009).

Ainda se tratando da fragmentação e da falta de diálogo das profissões da atenção à saúde frente às demandas e necessidades de cuidado aos usuários, Mendes (2010) explora a dimensão da gestão do trabalho em saúde apontando que a lógica de hierarquização dos serviços tem raízes no cuidado centrado nos profissionais, com predomínio da perspectiva médica. Para esse autor, a organização do sistema fragmentado de atenção à saúde advém através de um conjunto de pontos de atenção à saúde isolados e incomunicados uns dos outros, incapaz de prestar uma atenção contínua à população, refletindo uma modelagem fragmentada e piramidal, sendo esse tipo de resposta insuficiente frente às necessidades de saúde no século XXI.

Para Bravo e Matos (2009), uma atuação competente do Serviço Social na Saúde pressupõe que o profissional deve estar articulado e sintonizado ao movimento dos trabalhadores e de usuários que lutam pela real efetivação do SUS, conhecer as condições de vida e trabalho dos usuários, bem como os determinantes sociais que interferem no processo saúde-doença, buscar a necessária atuação em equipe, tendo em vista a interdisciplinaridade da atenção em saúde, superando a fragmentação dos serviços e do atendimento às necessidades sociais, além de outras competências.

Diante do exposto fica evidente que é impossível a prestação de serviço de saúde de qualidade sem que se tenha a interdisciplinariedade, interprofissionalidade e as práticas colaborativas, pois são pressupostos básicos para a efetivação de direitos de usuários e melhoria nas condições de vida dos mesmos, e, para que se consiga, de fato, trazer para a realidade do setor da saúde a efetivação dos mesmos.

Para Batista (2012), a Educação Interprofissional (EIP) apresentase, atualmente, como a principal estratégia para formar profissionais aptos para o trabalho em equipe, prática essencial para a integralidade no cuidado em saúde. Parte-se dos pressupostos de que, para se trabalhar nesse contexto, é necessário ressignificar dois conceitos essenciais - o de educação e o de saúde.

Ainda segundo o autor acima citado, a educação deve ser entendida com uma perspectiva dialógica e crítica, que proporciona construção dos conhecimentos, e, assim, favorece a transformação social. A concepção da educação vai além, em relação à perspectiva construtivista, porque o conhecimento é concebido como processo de construção e o aluno assume 0 papel de sujeito do processo de aprendizagem, mas, acima de tudo, rompe-se com a perspectiva tradicional da transmissão de conteúdo, do professor como detentor do saber e o aluno como receptor passivo de informações. 
No âmbito da saúde, Batista (2012) enfatiza que a mesma é entendida como concepção sócio-histórico-cultural e o foco é a integralidade do cuidado, com a equipe de saúde atuando em uma perspectiva interdisciplinar. Essa perspectiva avança em relação à concepção biopsicossocial, que considera o processo saúde-doença e reconhece a importância da multiprofissionalidade no cuidado, mas, acima de tudo, rompe com a concepção puramente biomédica da saúde, centrada na doença, tendo o médico como figura central.

Importante também enfatizar o momento atual em relação aos currículos dos cursos superiores em saúde. A implantação das DCNs (Diretrizes Curriculares Nacionais), promulgadas há 10 anos, ainda é um desafio, especialmente quando se fala sobre os mecanismos efetivos de integração curricular, diversificação de cenários de aprendizagem, articulação com o Sistema Único de Saúde (SUS), resgate da dimensão ética, humanista, crítico-reflexiva e cuidadora do exercício profissional, assumindo uma concepção ampliada de saúde (BATISTA. 2012).

A necessidade de integração também se configura como um desafio e assume ponto de destaque. Integração entendida numa perspectiva de novas interações no trabalho em equipe interprofissional, de troca de experiências e saberes e posição de respeito à diversidade, possibilitando-se, com isso, a cooperação para o exercício de práticas transformadoras, parcerias na construção de projetos e exercício permanente do diálogo.

A implantação da EIP na formação em saúde aparece como resposta a estas indagações. Consiste de oportunidades de treinamentos conjuntos para o desenvolvimento de aprendizagens compartilhadas. Enfim, ocasiões nas quais duas ou mais profissões aprendem juntas com e sobre as outras.

A EIP se compromete com uma formação para o interprofissionalismo, no qual o trabalho de equipe, a discussão de papéis profissionais, o compromisso na solução de problemas e a negociação na tomada de decisão são características marcantes; sempre com o foco no paciente. Para isto, a valorização da história de diferentes áreas profissionais, como o serviço social, a consideração do outro como parceiro legítimo na construção de conhecimentos, com respeito pelas diferenças num movimento de busca, diálogo, desafio, comprometimento e responsabilidade são componentes essenciais, deixando para trás esse viés conservador e a hierarquização ainda presentes nas profissões da saúde (BATISTA. 2012).

Portanto, pode-se dizer que, a interprofissionalidade deve ser uma aliada ao Serviço Social e às demais profissões da saúde, uma vez que essa busca o diálogo entre os profissionais, maior articulação entre as profissões, a integralidade dos mesmos e um enfoque maior no usuário, proporcionando, também, a integração do conhecimento e a oportunidade de busca de 
respostas aos desafios da contemporaneidade, requisitando do profissional um olhar diferenciado e amplo para compreender a dinâmica determinada na realidade em que se insere. É necessário romper com a visão individual, presa nos próprios muros de domínio de conhecimento profissional.

\section{CONSIDERAÇÕES FINAIS}

A análise da literatura, como mostrado acima, sob a visão dos autores citados, deixa claro que, ainda, atualmente, um dos problemas recorrentes na área da saúde é decorrente, diversas vezes, da hierarquização das profissões, sendo que, por esse motivo, o diálogo e as opiniões de diferentes profissionais fiquem em segundo plano, prejudicando assim o usuário. Com isso, o Serviço Social, que hoje é uma profissão de extrema importância na área da saúde, e trabalha com informações sobre o usuário e luta por uma qualidade melhor de vida para o mesmo, tem o seu trabalho dificultado.

Fica evidente também que através da interprofissionalidade essa questão da hierarquização das profissões poderá ser resolvida, com êxito, se aplicada de forma séria e ampla nos espaços de saúde, e, que, através dela, profissionais e usuários serão beneficiados. Os usuários poderão ter um atendimento de alta qualidade, com menores chances de erros ou duplicidades de atendimentos e maior resolutividade; para os profissionais, uma vez que trabalharão juntos e de forma articulada, um ajudando o outro, o trabalho fica menos extenuante, além de que, a resolução dos problemas se torna mais simples.

É certo que para que a interprofissionalidade atinja seu nível máximo de sucesso é necessário empenho e estudo sobre o tema, e que todos estejam engajados na mesma perspectiva e foco, trabalhando juntos e com enfoque na qualidade de vida e bem-estar do usuário: Ensino, Serviço de Saúde e Comunidade.

E através do projeto PET, Programa de Educação pelo Trabalho, docentes e alunos, engajados com essa ideia da interprofissionalidade, podem ajudar a construir uma realidade diferente, aos profissionais de diferentes áreas e aos estudantes que estão para ingressar nas suas respectivas áreas de atuação, mostrando e comprovando que através de um trabalho em equipe, interprofissional, articulado, o mesmo se torna mais resolutivo, assim como os benefícios aos usuários e equipe.

Diante do contexto, percebe-se a importância da educação interprofissional para o fortalecimento do SUS, ao mesmo tempo em que se compreende a urgência em ampliar discussões sobre a prática do trabalho 
colaborativo e interprofissional, em busca da superação dos desafios do Serviço Social na área da saúde.

\section{REFERÊNCIAS}

ARAUJO,T. A. M.,VASCONCELOS, A, C. C. P., PESSOA, T. R. R. F.; FORTE, F. D. S. Multiprofissionalidade e interprofissionalidade em uma residência hospitalar: o olhar de residentes e preceptores. Rev. COMUNICAÇÃO SAÚDE EDUCAÇÃO, 2017. Disponível em: http://www.scielo.br/pdf/icse/v21n62/1807-5762-icse-1807-576220160295.pdf. Acesso em: 10 mai.2019.

BARDIN, L. (2002). Análise de conteúdo. Lisboa: Edições 70.

BATISTA, A. N. Educação Interprofissional em Saúde: concepções e

Práticas. Caderno FNEPAS. Vol. 2. Jan.2012. Disponível em: http://www.fnepas.org.br/artigos caderno/v2/educacao interprofissional.pdf. Acesso em: 17 mai. 2019.

BRAVO, M. I. S.; MATOS, M. C. Projeto ético-político do Serviço Social e sua relação com a reforma sanitária: elementos para o debate. In: MOTA, $A$. E. et al. (Org.). Serviço Social e saúde: formação e trabalho profissional. São Paulo: Cortez, 2009.

COSTA, M. D. H. O trabalho nos serviços de saúde e a inserção dos(as) assistentes sociais. In: MOTA, A. E. et al. (Org) Serviço Social e Saúde: Formação e Trabalho Profissional. 4. Ed. São Paulo: Cortez, 2009.

CONSELHO FEDERAL DE SERVIÇO SOCIAL- CFESS. Parâmetros para Atuação de Assistentes Sociais na Saúde. Brasília, 2009. Disponível em: http://www.cressrs.org.br/arquivos/documentos/\%7B3412879E-C2CC-43679339-847E62E3E82E\%7D parametros saude.pdf. Acesso em: 14 mai.2019.

ELY, L. I.; TOASSI,R. F. C. Integração entre currículos na educação de profissionais da Saúde: a potência para educação interprofissional na graduação. Rev. Interface: Comunicação, Saúde, Educação. Botucatu, 2018. Disponível em: https://www.scielosp.org/article/icse/2018.v22suppl2/15631575/\#. Acesso em: 10 mai.2019.

ESCALDA, P. M. F.; FOGUET-BOREU, Q.; PARREIRA, C.M.S.F.; CYRINO, A.A. Interprofissionalidade e prática colaborativa no âmbito da Atenção Primária em Saúde. Ver. Argum., Vitória, v. 10, n. 3, 2018. Disponível em: https://www.researchgate.net/publication/329882077 Interprofissionalidade e pratica colaborativa no ambito da Atencao Primaria em Saude Interprofes sionality and collaborative practice in Primary Healthcare. Acesso em: 15 mai.2019.

IAMAMOTO, M. V. As Dimensões Ético-políticas e Teórico-metodológicas no Serviço Social Contemporâneo. in MOTA, Ana Elizabete (org. et al.) 
Serviço Social e Saúde: Formação e Trabalho Profissional. São Paulo:

Cortez,2008.

IAMAMOTO, M.V.; CARVALHO, R de. Relações Sociais e Serviço Social No Brasil: Esboço de Uma Interpretação Histórico-Metodológica. 35ํe. São Paulo: Cortez, 2011

MENDES, E,V. As redes de atenção. Rev. Ciências e Saúde Coletiva. 2010; 15(5):2297-305. Disponível em:

http://www.scielo.br/pdf/csc/v15n5/v15n5a05.pdf. Acesso em: 12 mai.2019.

PEDUZZI, M; NORMAN I. J. NORMAN; GERMANI, A.C.C.G.; SILVA, J.A.M.; SOUZA, G.C. Educação interprofissional: formação de profissionais de saúde para o trabalho em equipe com foco nos usuários. Rev. Escola de Enfermagem.Vol.47. N.4. 2018. Disponível em:

http://www.revistas.usp.br/reeusp/article/view/78051. Acesso em: 12 mai.2019.

SOUTO, S.H.; BATISTA, S.H.; BATISTA, N.A. A Educação Interprofissional na Formação em Psicologia: Olhares de Estudantes. Ver. PSICOLOGIA: CIÊNCIA E PROFISSÃO, 2014, vol. 34, nำ1. Disponível em:

http://www.scielo.br/pdf/pcp/v34n1/v34n1a04.pdf. Acesso em: 17 mai.2019

ORGANIZAÇÃO DAS NAÇÕES UNIDAS.OMS: expectativa de vida sobe 5 anos de 2000 a 2015 no mundo, mas desigualdades persistem. 2016. Disponível em: < https://nacoesunidas.org/oms-expectativa-de-vida-sobe-5anos-de-2000-a-2015-no-mundo-mas-desigualdades-persistem/> Acesso em 20 Jan 2019.

United Nations, Department of Economic and Social Affairs, Population Division (2017). World Population Prospects: The 2017 Revision, Key Findings and Advance Tables. 2017. Disponível em: < https://esa.un.org/unpd/wpp/Publications/Files/WPP2017 KeyFindings.pdf> Acesso em 20 Jan 2019.

Plano de Ação Internacional de Viena Sobre o Envelhecimento.1982. Disponível em < http://www.ufrgs.br/epsico/publicas/humanizacao/prologo.html> Acesso em 22 Jan 2019.

ORGANIZAÇÃO MUNDIAL DE SAÚDE. Relatório Mundial de Envelhecimento e Saúde. Genebra, 2015.

. Envejecimiento activo: um marco político. Madrid, 2002.

SILVA, L. R. F. Da velhice à terceira idade: o percurso histórico das identidades atreladas ao processo de envelhecimento. In: REDALYC, v.15, n.1, p.155-168, jan.-mar. 2008. Disponível em < http://www.redalyc.org/articulo.oa?id=386138034009> Acesso 07 Jul 2019. 
TEIXEIRA, S.M. Envelhecimento do trabalhador e as tendências das formas de proteção social na sociedade brasileira. In: Argumentum, v.1; n.1; p. 63-77; juldez, 2009.

Envelhecimento e trabalho no tempo de capital: implicações para a proteção social no Brasil. São Paulo: Cortez, 2008. 


\title{
PERSPECTIVAS EM DISPUTA: Olhares das trabalhadoras do sexo de Franca sobre a violência sexual e o estupro
}

\author{
BARBOSA, Marcela Dias \\ Doutoranda em Direito - Universidade de Granada, Espanha \\ marceladias@correo.ugr.es
}

\section{INTRODUÇÃO}

Entre inquietações, dúvidas e experiências em espaços coletivos de debate, pesquisa e práticas feministas gestei este trabalho. $O$ interesse pelo tema surge a partir da atuação, durante a graduação em Direito, no grupo de pesquisa e extensão, "Margarida Alves," na Unesp, campus de Franca. Mais tarde, em 2015, pela aproximação com o "Centro de Prevenção em DST/Aids", do município, e com as garotas de programa18 usuárias do Programa.

Nesta trajetória, ao me interessar pelas relações nas quais se envolvem as garotas de programa em Franca, vejo que meus conhecimentos elaborados sobre gênero, sexualidade e, mais especificamente, prostituição, eram (e continuam) limitados. No meu primeiro esforço interpretativo me via tentada a conformar as realidades observadas e descritas em uma estrutura maior de dominação masculina, uma ferramenta conceitual que conhecia, porém, não sabia muito bem como utilizar. Foram as conversas na casa de Raquel19, de Beth, na chácara de Isabel20, nos bares da Avenida Brasil, as tardes na região da "Baixada" 21 que me fizeram perceber que as dinâmicas não se davam da forma que eu imaginava. Eu percebia abusos, violências e

18 Uma diversidade de maneiras é usada na literatura específica para nomear as mulheres que realizam prostituição. Essas diferenças de termos não expressam apenas uma mudança terminológica, mas também esta contida a visão de mundo e entendimento que as mulheres têm sobre si e sobre a prostituição que desempenham. Em Franca, as garotas se autodenominavam de garotas de programa, assim o nomearei aqui, intercalando com termos que dão da ideia da prostituição enquanto trabalho.

19 Seguindo as exigências éticas sobre pesquisas envolvendo seres humanos, em especial, a necessidade de termo de consentimento assinado por mim e pelas entrevistadas, com todas as informações sobre a pesquisa, foram suprimidos os nomes reais e qualquer outro dado que pudesse quebrar o anonimato das interlocutoras deste trabalho.

20 A casa de Raquel, a casa de Beth e a chácara de Isabel foram os locais onde pude dialogar com as interlocutoras desta pesquisa, todas introduzidas por João Carlos Doná, profissional responsável pelo "Centro de Prevenção em DST/Aids".

21 Ao longo do trabalho, também entrei em contato com a ONG Vitória Régia, em Ribeirão Preto. Acompanhada de Regina Brito (ativista no movimento pela defesa dos direitos das mulheres prostitutas) e Eulalia Fabiano (doutoranda em Ciências Sociais), estive nas intervenções realizadas na região da "Baixada", conhecido lugar que abriga casas antigas, instituições públicas, bancos, comércio e o mercado central da cidade, também onde funcionam bares e motéis, principalmente durante o dia, frequentados pelas garotas de programa, clientes e transeuntes. Fomos com frequência na movimentada Avenida Brasil, entre os bairros Quintino Facci I e Jardim Salgado Filho, próximos a saída da cidade de Ribeirão Preto, espaço em que as garotas de programa batalham nas ruas, nas casas de prostituição e nos motéis. 
marcadas relações de poder. Contudo, esses ganhavam contornos e sentidos variados.

Ainda confusa e sem saber por onde começar também tive a oportunidade de conversar com Estela Scandola, colega, professora e assistente social, a qual conheci em uma adorável visita que fiz à cidade de Campo Grande, MS. Estava iniciando o meu mestrado, tinha pouca familiaridade com o tema e me movia pela curiosidade e por algumas "intuições". Marcou-me nosso diálogo e sua sutileza para alertar-me de que havia mais coisas por traz destas tais intuições do que eu imaginava. Exemplificou com uma experiência sua: ela viajava de uma cidade à outra, acompanhada de uma amiga sua, quando passaram em frente a uma grande indústria de alimentos. Enquanto ela me cativava com sua narrativa, eu remontava a cena na minha imaginação: ali, sua amiga olhou para o grande estabelecimento e lembrou-se dos longos anos em que passou fazendo atividades repetitivas com as mãos, até ter comprometido os seus movimentos. A lembrança fez com que comparasse seu antigo trabalho com a prática da prostituição, atividade que laborava no momento e avaliando o que se costuma pensar sobre a profissão, chegando à conclusão: "depois dizem que são as prostitutas aquelas que vendem os seus corpos".

A narrativa me deixou pensativa por um longo período e creio que assim continuo. O contato com novas perspectivas (para mim) sobre a prática da prostituição foi ampliando o meu campo de visão e dando espaço para novas perguntas. O contato com as interlocutoras da pesquisa, os debates em sala de aula, os seminários, os congressos e as leituras, ofereceram aportes para algumas das reflexões que trago neste trabalho e os pontos de vista que aparecem a partir destes diálogos. Eu, também, assim como elas, sou (somos) mulher(es) e, diante disto, tenho meus próprios conceitos e experiências sobre o (meu/nosso) gênero, que acabaram sendo postos em termos que dialogavam com aqueles utilizados pelas garotas de programa.

Sentia que a poderosa voz do direito e sua única versão em relação à prostituição, à violência sexual e ao estupro me incomodavam. Assim, considero um ponto de partida o fenômeno da violência contra as mulheres e o contraste entre as narrativas hegemônicas do direito sobre o que pode ser reconhecido enquanto violência sexual e estupro daquilo que expressam, vivem e reivindicam as vozes silenciadas pelas instituições.

\section{VIOLÊNCIA SEXUAL CONTRA AS MULHERES BRASILEIRAS E O SISTEMA DE JUSTIÇA CRIMINAL}

No Brasil, estima-se que pelo menos uma de cada três mulheres sofre violência sexual ao menos uma vez durante sua vida (FAÚNDES, 2006, p. 127). Contudo o maior destaque se dá à sua invisibilidade: estima-se que 
apenas $10 \%$ dos casos são contabilizados e reportados à polícia. Ou seja, a maioria das mulheres que já se deparou com uma situação de violência não viu as instituições jurídicas e de saúde como espaços de acolhimento e de escuta às suas reivindicações, o que talvez comunique a dificuldade em traçar sua relação com a saúde sexual e reprodutiva das mulheres22, ainda negligenciadas (FAÚNDES, 2006).

Segundo Nota Técnica produzida pelo Ipea sobre os estupros no Brasil, do mês de março de 2014, entre os casos notificados, estima-se que $88,5 \%$ das vítimas eram do sexo feminino, mais da metade tinha menos de 13 anos de idade, $51 \%$ eram negras 23 e, de modo geral, $70 \%$ dos estupros foram cometidos por parentes, namorados ou amigos/conhecidos da vítima. Os dados além de indicar que a violência nasce no seio da família, também apontam que a maioria esmagadora dos agressores são homens, independentemente da faixa etária da vítima (CERQUEIRA; COELHO, 2014, p. 7).

A violência sexual e o estupro são um fator de risco para todas as mulheres. Contudo, elementos como raça, etnia, orientação sexual, gênero, classe social, deficiência, idade, religião, escolaridade, origem territorial e nacionalidade conjugam-se de modo a intensificar as condições de risco de determinados grupos (SEVERI, 2017, p. 18). O Mapa da Violência (WAISELFISZ, 2015), por exemplo, evidencia que a articulação24 entre sexismo e racismo gera um percentual elevado de violência sobre as mulheres negras (entre 2003 e 2013, sofre um aumento de 54,2\%), enquanto tende a cair o percentual de violência sobre as mulheres brancas (no mesmo período, com queda de 9,8\%). Tais dados alertam para outras formas de discriminação e violação de direitos, além de gênero, que estão imbricadas nas situações de violência embora ainda permaneçam silenciadas.

As dificuldades no reconhecimento da violência ou da violação contra a saúde sexual, reprodutiva e os direitos humanos das mulheres ficam

\footnotetext{
${ }^{22}$ As consequências da violência sexual podem ser imediatas e de longo prazo e são tanto físicas, como psicológicas. Dentre elas estão: o risco de adquirir uma doença sexualmente transmissível (DST) com a possibilidade de se infectar, particularmente pelo HIV; o trauma físico genital ou de outras partes do corpo; a gravidez não desejada; o desenvolvimento de fobias, depressão, ansiedade, estresse pós-traumático, somatização, entre outros (FAÚNDES, 2006, p.128). Além de afetar a saúde física e psíquica das vítimas, atinge toda a sociedade ao colocar o medo como um elemento da existência das mulheres que pode limitar suas decisões e, consequentemente, afetar seu pleno potencial de desenvolvimento.

${ }^{23}$ É importante considerar que os dados são quantificados a partir dos casos notificados e, como visto, a maior parte dos estupros são subnotificados. Quando confrontamos os números da Nota Técnica com os percentuais do Mapa da Violência de 2015, não parece ser paritária a vitimação entre mulheres negras e mulheres brancas.

${ }^{24}$ Trabalharemos com maior profundidade no próximo capítulo as categorias de articulação e a interseccionalidade, mas já adianto a importância em pensarmos na desestabilização da categoria "mulher" para refletirmos as opressões que afetam de modo qualitativamente diferente os distintos grupos de mulheres.
} 
ainda mais evidentes quando perpassam pelo sistema de justiça criminal. (CASTILHO, 2008; PIMENTEL; SCHRITZMEYER, PANDJIARJIAN, 1998; SABADELL, 2013). Tanto no campo jurídico como em outros espaços de sociabilidade quando se trata de um crime sexual, predomina o imaginário vinculado ao julgamento da reputação sexual, do comportamento, da vida pregressa ou status familiar das mulheres, o que deve se agudizar, principalmente, no tratamento dispensado às garotas de programa que ainda tem como obstáculo o estigma25 construído sobre si e seu trabalho (PETHERSON,1996).

Até 2005, apenas as mulheres "honestas" podiam reivindicar o lugar de vítima na conduta prevista no Código Penal de "posse sexual mediante fraude". No crime de estupro26, antes de sua última alteração, em 2009, somente as mulheres ocupavam o polo passivo da relação e a conduta delitiva se consumava pela conjunção carnal, mediante violência ou grave ameaça. Enumero, ainda, a revogação do que esteve presente desde o Código Penal brasileiro de 1940: a extinção de punibilidade ao estuprador caso ele se casasse com a vítima. Ou seja, as condutas consideradas até recentemente como "crimes contra os costumes"27 deixavam explícito o caráter discriminatório das leis e o poder do direito em normatizar e conformar as relações de gênero e sexualidade.

Apesar das referidas mudanças, o tratamento penal em relação ao crime de estupro continuou sendo pautado pelo que Vera Regina Pereira de Andrade (2005, p.89) chama de "lógica da honestidade". Tal lógica estabelece uma grande linha divisória e seletiva entre as mulheres consideradas honestas (do ponto de vista da moral sexual dominante) e que podem ser consideradas vítimas, das mulheres desonestas (das quais a prostituta é o modelo radicalizado), "abandonadas" pelo sistema de justiça criminal, na medida em que não se adequam aos padrões de moralidade sexual impostos às mulheres.

O combate à violência contra as mulheres, portanto, nos casos envolvendo o crime de estupro, não estará na função latente e real do sistema de justiça criminal. Ao contrário, para a autora (ANDRADE, 2005, p. 91), opera na construção seletiva e estigmatizante, reproduzindo, assim, materialmente, as desigualdades e assimetrias sociais de classe, gênero, raça, dentre outros marcadores. Neste processo, precisamente o núcleo do controle dos corpos de mulheres estará no controle da sexualidade, desde a criminalização primária

\footnotetext{
${ }^{25}$ Gail Petherson (1996, p.82) define o estigma de prostituta como "a marca de vergonha ou enfermidade que marcam uma mulher escrava incasta ou criminosa". A autora indica que o estigma de puta vincula a desonra da prostituta com a falta de legitimidade das mulheres em geral, atribuindo àquelas que realizam o intercâmbio de sexo por dinheiro, a diferenciação mediante a vergonha.

${ }^{26}$ A partir de 2009, no artigo 213, o tipo penal estupro dispõe: "Constranger alguém, mediante violência ou grave ameaça, a ter conjunção carnal ou a praticar ou permitir que com ele se pratique outro ato libidinoso".

${ }^{27}$ Com as modificações de 2009, o Título IV passa a tratar dos "crimes contra a dignidade sexual”.
} 
(definições legais dos tipos penais ou discurso da Lei) até os diferentes níveis da criminalização secundária (inquérito policial, processo penal ou discurso das sentenças e acórdãos) e a mediação do discurso dogmático entre ambas.

Com a seletividade evidenciada, dentre outras contradições que exsurgem do sistema de justiça, são distintos os posicionamentos em relação ao uso do direito para efetivação das demandas dos movimentos feministas. Não desenvolveremos diretamente este debate na pesquisa, mas pontuo 0 meu posicionamento em relação ao tema. Alinho-me ao que propõe Fabiana Cristina Severi (2017, p. 22) para entender as tensões entre direito e feminismos "não mais em termos de antagonismos - ou paradoxos a serem, necessariamente, resolvidos em favor de um ou outro polo da equação -, mas como dimensões de uma dinâmica de disputas que nem sempre se resolvem em favor da ampliação e da realização desse projeto." A autora (SEVERI, 2017 , p. 22) lembra que as políticas em defesa dos direitos humanos das mulheres podem produzir, muitas vezes, efeitos de colonização e racialização, contudo, são entre essas disputas que está a capacidade do campo feminista em desafiar o poder do direito.

Teremos como referências, portanto, as discussões teóricas feministas que questionam e desafiam o uso das instituições jurídicas e políticas estatais para o enfrentamento da violência contra as mulheres ou para a busca de transformações nas relações de subordinação. A atenção a questões como o colonialismo, o racismo e o heteronormativismo tornam ainda mais complexas as problemáticas vinculadas ao processo de institucionalização estatal para o enfrentamento da violência de gênero. Mulheres prostitutas, mulheres transexuais, mulheres de zonas urbanas periféricas ou de zona rurais, mulheres indígenas, mulheres negras, por exemplo, podem deixar de buscar o sistema de justiça tanto pelo receio dos efeitos penais sobre si e seus agressores, como pela distância física (e subjetiva) das delegacias e juizados (SEVERI, 2017, p. 21). Ou ainda, pela incompatibilidade das narrativas sobre a concepção de violência nas instituições daquelas construídas pelas próprias mulheres, em seus distintos locais de enunciação.

Atenta a este desafio, ressalto a participação dos movimentos feministas brasileiros e latino-americanos na disputa pelo reconhecimento de violências praticadas contra as mulheres a partir da década de 1990 e os compromissos da Convenção Internacional sobre a Eliminação de Todas as Formas de Discriminação contra a Mulher (CEDAW), de 1981, e da Convenção Interamericana para Prevenir, Sancionar e Erradicar a Violência contra as Mulheres (Convenção Belém do Pará), de 1994. As obrigações assumidas pelos países em criar mecanismos legais para efetivação dos direitos humanos das mulheres e para a implementação de serviços que garantissem o acesso à justiça e a atenção integral das mulheres em situação de violência deram 
subsídios para que as articulações feministas se engajassem na conquista de políticas públicas com este objetivo.

Os tratados significam um marco para o processo histórico de construção e reconhecimento dos direitos das mulheres como direitos humanos, no Brasil. Porém, é através do amplo enfrentamento estratégico dos movimentos de militantes feministas que a violência ganha visibilidade no espaço público e recebe prioridade pelo Estado brasileiro, compelido a se responsabilizar pela efetivação destes direitos. A intensa resistência e luta feminista resulta na conquista, em agosto de 2006, da Lei Federal $n . \stackrel{0}{11.340}$ ou Lei Maria da Penha28, que cria mecanismos para coibir e prevenir a violência doméstica e familiar contra as mulheres.

A legislação contempla medidas judiciais e extrajudiciais adotando uma concepção ampla de acesso à justiça e a direitos a partir da perspectiva de gênero. Por sua abrangência, o texto legislativo é considerado um conjunto de políticas públicas cuja aplicação integral e em rede com outros setores (saúde, segurança pública, educação e assistência social) depende do compromisso do Executivo, do Judiciário e do Legislativo nas esferas do governo federal, dos estados e municípios (PASINATO, 2015, p. 489).

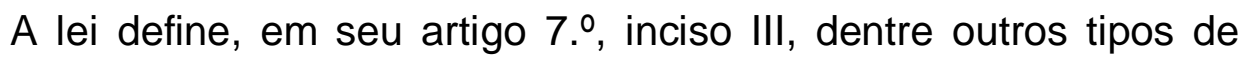
violência doméstica e familiar contras as mulheres, a violência sexual como:

[...] qualquer conduta que a constranja a presenciar, a manter ou a participar de relação sexual não desejada, mediante intimidação, ameaça, coação ou uso da força; que a induza a comercializar ou a utilizar, de qualquer modo, a sua sexualidade, que a impeça de usar qualquer método contraceptivo ou que a force ao matrimônio, à gravidez, ao aborto ou à prostituição, mediante coação, chantagem, suborno ou manipulação; ou que limite ou anule o exercício de seus direitos sexuais e reprodutivos.

Amplia-se o entendimento do que pode ser considerado como violência sexual pela narrativa da Lei Maria da Penha. O exercício dos direitos sexuais e reprodutivos das mulheres passa a ter relação direta com 0 fenômeno da violência e expande-se a noção de consentimento que deixa, por exemplo, de ser presumido dentro dos relacionamentos fixados pelo contrato do casamento. O respeito à autonomia, à sexualidade e aos desejos das mulheres ganham destaque e, ao menos no discurso legal, fundam novas diretrizes para o tratamento da violência sexual pelas instituições estatais.

Apesar dos avanços, Maria Filomena Gregori (2008 b, p.166) alerta para "[...] uma persistente desigualdade social no acesso à justiça". A autora lembra que o acesso à justiça implica negociações entre atores sociais

\footnotetext{
${ }^{28} \mathrm{Na}$ redação da lei um consórcio de ONGs (CLADEM, CEPIA, CFEMEA, AGENDE, THEMIS) exerceu uma inovadora ação legislativa apresentada aos Poderes Executivo e Legislativo que foi aprovada com apenas poucas alterações. Esse consórcio manteve uma ação de advocacy em todo o percurso de tramitação do projeto que deu origem à lei (PASINATO, 2015).
} 
que não têm o mesmo poder na disputa que formata as regras do jurídico. As dinâmicas de negociação no âmbito da justiça são complexas, envolvem limites, possibilidades e, principalmente, dessimetrias de poder relativas a gênero que se intersecciona com outras dimensões recortadas por relações de classe, raça, idade, dentre outras diferenças, convertidas em desigualdades.

Tendo em vista tais dilemas, aqui, importa levantar algumas questões em torno das disputas narrativas pelo reconhecimento da violência sexual e a aproximação às próprias formas de organização das mulheres e de suas resoluções de conflitos envolvendo gênero, raça, classe, idade, dentre outros marcadores sociais. $O$ esforço está em analisar o funcionamento do sistema de justiça criminal e as narrativas em relação ao estupro a partir das percepções das garotas de programa, em Franca, e de suas noções e reinvindicações sobre o que deve ser reconhecido enquanto violência sexual.

Neste sentido, Roberto Efrem Filho (2017, [p. 8]), em seu artigo "A reivindicação da violência: gênero, sexualidade e a constituição da vítima", aponta para a não obviedade da violência e da brutalidade. $O$ autor chama de enfrentamento analítico-político das relações de poder o que permite ou não a arquitetura narrativa do ato de violência como uma imagem de violência, da vítima como vitimável; do acusado como acusável. E discute como as relações de gênero e de sexualidade operam na tessitura de narrativas sobre a violência e, ao revés, como a reivindicação narrativa da violência atua no perfazimento de relações de gênero e de sexualidade - relações reciprocamente constituídas por relações de classe, racialização, geração, territoriais, etc.

Seguindo essas contribuições, parece interessante, a distinção estratégica que Gregori (2008, p. 176) faz entre crime e violência. Para a autora "[...] crime implica a tipificação de abusos, a definição das circunstâncias envolvidas nos conflitos e a resolução destes no plano jurídico". Já a violência é lida como "[...] um termo aberto aos contenciosos teóricos e às disputas de significado que implica reconhecimento social (não apenas legal) de que certos atos - [inseridos em] dinâmicas conflitivas que supõem processos interativos atravessados por posições de poder desiguais entre os envolvidos [constituem abuso]".

Creio que estes são os elementos que considerei relevantes para introduzir as leitoras e leitores e algumas contribuições ao debate que certamente (e felizmente) não se encerra nas discussões aqui presentes.

\section{CONSIDERAÇÕES FINAIS}

Estupro de trabalhadoras do sexo em Franca: vítimas ou vilãs? A partir deste questionamento, no início do meu percurso exploratório, buscava 
compreender questões polêmicas como a prostituição, o estupro, a violência sexual e as intermediações do sistema de justiça criminal. Em um chão movediço, nunca tive certeza de que esta era a melhor pergunta a ser lançada. Percebia que estes termos eram comumente confundidos e muitas vezes instrumentalizados para desqualificar, silenciar e apagar 0 ativismo das mulheres trabalhadoras do sexo. Via como um desafio e uma necessidade, portanto, construir distinções claras entre a prática da prostituição e a violência sexual, elementos que antes de serem lidos conjuntamente, deveriam ser cuidadosamente diferenciados.

O trabalho do sexo não carrega, em si, traços de violência.

Aqui, penso, em mães, filhas, avós, tias, primas, mulheres trabalhadoras, arrimos de famílias que exercem suas profissões, assim como eu, assim como vocês, leitoras desta investigação. Mulheres comuns, mulheres guerreiras. Pagamos nossas contas, vamos ao banco, à farmácia, ao posto de saúde, nos transportamos de um local a outro, temos casos de amor, casos de ódio, afetos mais ou menos próximos, amamos, brigamos, sorrimos, nos angustiamos, queremos bem as pessoas que escolhemos ter por perto e no fundo...o que acredito mesmo, é que todas nós queremos ser respeitadas.

Em um contexto androcêntrico, racista, classista, eurocêntrico e marcado por relações de poder hierárquicas, de maneira muito distinta, nós mulheres, estamos suscetíveis à violência. Todas. Em casa, em sala de aula, nos escritórios, nas fábricas, nas ruas, nos hospitais, nas delegacias, nos fóruns, nos puteiros. E, não podemos partir da premissa de que um espaço é mais seguro que o outro porque envolve uma atividade ou grupo de pessoas mais ou menos valorizados socialmente. Fosse assim, poderíamos facilmente encerrar o debate e descansarmos tranquilas com as nossas ingênuas certezas.

Colocar o dedo em riste para as trabalhadoras do sexo como se carregassem e alimentassem o "mal" da dominação masculina, certamente, não resolve os nossos problemas e pouco contribui para o enriquecimento do debate sobre a violência contra as mulheres.

Então, proponho um primeiro esforço: olhemos para nós. Quantas vezes sentimos doer a injustiça nos espaços que ocupamos? Quantas vezes tivemos que enfrentar, ter voz de comando e subverter as desigualdades que nos roubam vida e vitalidade? Quantas vezes, dentre tantas contradições, sem muito racionalizar nos colocamos no lugar de outras, e resistimos à subjugação de nossos pares? Quantas vezes, falhamos, e reproduzimos, mais do mesmo, rechaçando o que consideramos diferente de nós? Ou quem sabe, rechaçamos o diferente que carregamos como parte constituinte do nosso ser. Até quando vamos travar essa luta contra "o outro" que ao fim e ao cabo, somos nós mesmas? 
O estatuto legal da prostituição, no Brasil, adotando uma postura abolicionista oferece às trabalhadoras do sexo o status de vítimas a serem "tuteladas" pelo Estado. O resultado é o controle da atividade principalmente pela força policial, a clandestinidade e inúmeros obstáculos para o exercício de um trabalho salubre, remunerado, protegido por garantias civis, trabalhistas, previdenciárias. Legalmente, o trabalho sexual não é penalizado, mas todo 0 seu entorno o é (agenciar, aliciar, transportar, transferir, comprar, alojar, acolher). Na prática, mesmo sem amparo legal, a atividade é controlada, criminalizada e duramente reprimida pelos aparatos estatais.

O reforço do estigma à profissão por políticas públicas que equiparam a prostituição à exploração sexual geram um contexto em que as mulheres trabalhadoras para protegerem-se da violência moral, devem se esconder e ocultar a atividade que exercem. Devem apagar suas histórias de vida, experiências, aprendizados para que possam ser preservadas do alto impacto do patriarcado. E mais do que o cuidado com suas clientelas, ajustamse para sobreviver às estruturas institucionalizadas ou não, voltadas para 0 combate à existência de mulheres que subvertem as normativas impostas aos gêneros construídos.

E na resistência, criam suas próprias formas de organização e redes de apoio. A prática ensina como podem trabalhar com maior segurança e as experiências dão elementos para que possam reivindicar e evitar o que sentem como violência. $O$ respeito ao uso do preservativo, o pagamento no valor ajustado, o tempo acordado, as restrições estabelecidas aos contatos corporais, à intimidade das trabalhadoras ou qualquer outra regra que apresentam como invioláveis são habilmente negociados e instituídos pelas trabalhadoras. E quando "um poder maior" que o das garotas de programa rompe com os limites impostos, manifesta-se uma potente forma de exercer violência contra as mulheres.

A interpretação de que seus corpos estão disponíveis para qualquer tipo de relações, além de ser incompatível com a realidade, dificulta a diferenciação entre a prostituição e a violência sexual e criam obstáculos para o combate ao estigma na profissão. Tratá-las como sinônimos também é ocultar as percepções sobre como vivem, veem, sentem e resistem à violência sexual.

Quando sentimos a prática, de nada adiantam os nomes atribuídos. E quando nos tiram o direito de criarmos nossa própria identidade, façamos uma prática combativa pelo uso dos nomes e conceitos que escolhemos. A expressão da sexualidade da forma que achamos pertinente é um direito e reivindica-la a nosso favor, também. A favor de uma vida melhor para as mulheres, livre de estigmas, livre de violências. Afinal, de que lado efetivamente estamos? 
Inicio o fechamento desses breves parágrafos. Aqui, busquei percorrer alguns atalhos para delimitar fronteiras. Muitas questões poderiam ter sido aprofundadas e exploradas, contudo minhas escolhas caminharam para o debate sobre os limites na prática da prostituição e sua relação com a violência sexual, o estupro e as intermediações das instituições estatais.

$\mathrm{Na}$ contramão da construção de versões únicas e de verdade produzidas pelo direito, as narrativas e reflexões desenvolvidas, neste percurso, buscaram ampliar o que pode ser reconhecido e reivindicado enquanto violência sexual e estupro. Em um processo de disputas, no (e fora do) campo jurídico, os sentidos atribuídos à prostituição e ao estupro colocam em evidência distintos posicionamentos e políticas em relação às questões de gênero e sexualidade intersectadas com marcadores de raça, classe, idade, localidade, dentre outros. Do mesmo modo, as narrativas tecidas pelas vozes de distintas mulheres operam no perfazimento de relações sociais e formas de articulação e organização em torno do enfrentamento à violência nos espaços em que atuam.

O tratamento penal sobre os delitos sexuais ganhou distintos contornos a partir das reivindicações dos movimentos feministas, principalmente com as mobilizações nas últimas décadas em torno da violência de gênero. No Brasil, até 2005, a designação "mulher honesta" esteve presente entre os delitos sexuais inseridos no que se caracterizava "crime contra os costumes". Em 2009, a reforma introduzida pela Lei n. ${ }^{\circ} 12.015$, dentre outras alterações, muda a definição do crime de estupro, ampliando o que pode ser entendido enquanto violência sexual, a partir de então, consumado pela conjunção carnal ou outro ato libidinoso, podendo ocupar o polo passivo da conduta tanto mulheres como homens.

Apesar destas e outras mudanças legais, diversos estudos e diagnósticos produzidos e apresentados ao longo do trabalho, demonstram que mantem-se uma definição legal estreita sobre o estupro e mais ainda, permanece intocada a atuação seletiva dos/as operadores/as do direito em relação ao que pode (e deve) ser reconhecido socialmente como violência sexual. Os parâmetros jurídicos ainda refletem valores culturais sobre a sexualidade das mulheres e operam delineando uma linha divisória entre as mulheres suscetíveis de ocuparem o espaço de vítima construído pelo sistema de justiça criminal, daquelas indignas e que não cumprem com as exigências morais estabelecidas. Coloca-se em relevo, portanto, a preocupação pelo julgamento das condutas, comportamentos e status familiar das mulheres em detrimento da tutela de seus direitos sexuais.

Paradoxalmente, ao mesmo tempo em que as mulheres prostitutas, nos casos envolvendo crimes sexuais, representam no imaginário jurídico o modelo radicalizado da mulher "desonesta", "vilã", também são 
caracterizadas como vítimas pelo tratamento penal brasileiro oferecido ao trabalho sexual.

Para além de categorias opostas, acredito que as vozes das garotas de programa de Franca, dão elementos para refletirmos brevemente os aprendizados, as negociações e os limites corporais e afetivos no mercado do sexo a partir dos sentidos que formulam, sem ignorar que foram constantemente intermediadas pela pesquisadora, inclusive na narrativa e organização de suas falas.

Creio que as tantas histórias, lembranças e memórias das garotas de programa são ricos conteúdos os quais alargam as fronteiras do conhecimento e vão além das imposições da academia eurocêntrica. São experiências que desafiam a cartografia do saber imperial pela resistência e poder de agência de mulheres vivas e intensas pela subversão e pluralidade de seus saberes.

\section{REFERÊNCIAS}

ANDRADE, Vera Regina Pereira de. A soberania patriarcal: o sistema de justiça criminal no tratamento da violência sexual contra a mulher. Sequência, Florianópolis, v. 50, p.71-102, 2005.

BARBOSA, Marcela Dias. "Voz de comando: experiências, aprendizados e limites na prática da prostituição. 13 MUNDO DE MULHERES E FAZENDO GÊNERO, 13., 2017, Florianópolis. Transformações, conexões e deslocamentos. Florianópolis: Ufsc, 2017. p. 1-12.

BARBOSA, Marcela Dias; BORGES, P. C.C. Trabalho sexual, estupro e sistema de justiça criminal: uma análise crítica a partir do feminismo de terceiro mundo. Revista Eletrônica do Curso de Direito da UFSM, Santa Maria, v. 12, n. 2, p.387-407, 2017.

CASTILHO, Ela Wiecko Volkmer de. A criminalização do tráfico de mulheres: proteção das mulheres ou reforço da violência de gênero? Cadernos Pagu, Campinas, v. 31, jul/dez. 2008, pp. 101-124. Disponível em : $<$ http://www.scielo.br/pdf/cpa/n31/n31a06>. Acesso em: 12 dez. 2016.

CERQUEIRA, Daniel; COELHO, Danilo de Santa Cruz. Estupro no Brasil: uma radiografia segundo os dados da saúde. Distrito Federal: Instituto de Pesquisa Econômica Aplicada, 2014.

EFREM FILHO, Roberto. A reivindicação da violência: gênero, sexualidade e a constituição da vítima. Cadernos Pagu, Campinas, n. 50, p. 1-54, 2017. 
Disponível em <http://www.scielo.br/scielo.php?script=sci_arttext\&pid=S0104$83332017000200308 \&$ Ing=pt\&nrm=iso >. Acesso em: 25 jul. 2017.

FAÚNDES, Aníbal et al. Violência sexual: procedimentos indicados e seus resultados no atendimento de urgência de mulheres vítimas de estupro. Revista Brasileira de Ginecologia Obstetrícia, São Paulo, v. 28, p.126-135, 2006.

GREGORI, Maria Filomena. Violência e gênero: novas propostas, velhos dilemas. Revista Brasileira de Ciências Sociais, São Paulo, v. 23, n. 66, p.165-182, 2008.

PASINATO, Wânia. Acesso à justiça e violência doméstica e familiar contras as mulheres: as percepções dos operadores jurídicos e os limites para a aplicação da Lei Maria da Penha. Revista de Direito GV, São Paulo, v. 11, p.407-428, 2015.

PETHERSON, Gail. El prisma de la prostitución. Madrid: Talasa Ediciones, 1996.

PIMENTEL, Silvia; SCHRITZMEYER, Ana Lúcia P.; PANDJIARJIAN, Valéria. Estupro ou "cortesia"? Abordagem sociojurídica de gênero. Porto Alegre: Sergio Antonio Fabris, 1998.

SABADELL, Ana Lúcia. Manual de sociologia jurídica. 6. Ed. São Paulo: Revista dos Tribunais, 2013.

SEVERI, Fabiana Cristina. Enfrentamento à violência contra as mulheres e à domesticação da Lei Maria da Penha: elementos do projeto feminista de legalidade no Brasil. 2016. 234 f. Tese (Livre-Docência) - Universidade de São Paulo, Ribeirão Preto, 2017.

WAISELFISZ, J. J. Mapa da Violência 2015: homicídio de mulheres no Brasil. Brasília: FLACSO/ONU-Mulheres/OPAS/OMS/SPM, 2015. 


\title{
POLÍTICA PÚBLICA MULTICÊNTRICA: Conceito e indicadores como contribuição crítica da realidade educacional brasileira
}

\author{
FARIA, Rafael Emilio \\ Mestrando - UNESP \\ MARTINO, Vânia de Fátima \\ Docente - UNESP
}

\section{INTRODUÇÃO}

Políticas públicas advindas da lógica gerencialista de administração vêm sendo implementadas no Brasil desde a reforma do Estado, no início da década de 1990. A distância temporal em que nos encontramos hoje permite uma confrontação empírica entre os conceitos/propostas (tipos ideais) e os resultados, contribuindo para uma concepção mais ampla do instrumental teórico utilizado para análise dessas políticas, assim como para a indicação de possíveis irracionalidades em suas execuções.

O presente texto trata mais especificamente de uma primeira aproximação no sentido de formular um novo conceito de políticas públicas multicêntricas, extraído da particularidade da implementação e dos resultados de tais políticas na educação fundamental brasileira.

Evidenciamos, através de um estudo descritivo analítico, que a descentralização política e administrativa da educação fundamental ocorreu e ocorre teórica e juridicamente dentro das intenções e do viés multicêntrico, no entanto, as realidades dos municípios, junto à determinada estrutura do pensamento político brasileiro, geraram um efeito reverso ao pretendido pelo multicentralismo, principalmente no que tange a gestão democrática/participação dos beneficiários, ou seja, daqueles a quem se destina a política.

Para tanto, primeiramente, fizemos uma breve explanação sobre o desenvolvimento do conceito clássico de política multicêntrica; em seguida, contextualizamos o advento de tais políticas à reforma do Estado brasileiro e o processo de municipalização do ensino fundamental; com isso, apontamos contradições entre o conceito e a realidade dos municípios brasileiros; para aí sim, apresentar o conceito de multicentralismo às avessas, mais adequado ao real. Na última seção, apresentamos e formulamos indicadores que podem revelar a porcentagem de escolas municipais com gestão democrática no Brasil.

\section{POLÍTICAS PÚBLICAS: As abordagens estatista e multicêntrica}


O conceito de política pública é relativamente diverso e conta com diferentes perspectivas. Três definições clássicas formam a abordagem estatista: a de Lawrence Mead29, que a define como um campo dentro do estudo geral da política que analisa o governo à luz das grandes questões públicas (MEAD, 1995); a de Guy Peters30, para quem política pública é a soma das atividades dos governos, que agem diretamente ou através de delegação e que influenciam a vida dos cidadãos (PETERS, 1996); a de Thomas Dye31, que sintetiza a definição de política pública como o que o governo escolhe ou não fazer (DYE, 1984).

Cada um desses conceitos possui particularidades e elementos positivos para a ciência das políticas públicas. Consecutivamente atentaram para a importância da agenda, pois as questões públicas são o elemento central na definição de Mead; para o histórico das políticas públicas e 0 destaque para o cidadão, em Peters; e a possibilidade de uma política pública também ser aquilo que não se faz ou se opta por não fazer, como Dye entende.

No entanto, existem críticas a essas definições, justamente em relação ao que, de maneira geral, elas têm em comum: superestimam aspectos racionais e procedimentais e concentram-se no papel dos governos deixando de fora as possibilidades de cooperação que podem ocorrer entre os governos e outras instituições e grupos sociais:

\begin{abstract}
A abordagem estatista admite que atores não estatais até tenham influência no processo de elaboração e implementação de políticas públicas, mas não confere a eles o privilégio de estabelecer (decidir) e liderar um processo de política pública. Já acadêmicos da vertente multicêntrica admitem tal privilégio a atores não estatais. (SECCHI, 2013, p. 3).
\end{abstract}

Diante de tais críticas, abriu-se a possibilidade de uma abordagem multicêntrica, ou seja, de vários centros além do estatal. Nesse viés, a política pública é caracterizada pela abrangência do seu atendimento: a ação visa atender o interesse público? Se sim, pode ser proposta por diferentes organizações e atores: privados, governamentais, multilaterais etc.

\title{
3. AS POLÍTICAS PÚBLICAS MULTICÊNTRICAS, A REFORMA DO ESTADO NO BRASIL E A MUNICIPALIZAÇÃO DO ENSINO FUNDAMENTAL
}

As políticas públicas multicêntricas ganharam terreno dentro da reforma estatal brasileira a partir da década de 1990, marcada pela lógica gerencialista adaptada de tecnocratas, experiências de mercado e por princípios como: descentralização do ponto de vista político, transferindo recursos e atribuições para os níveis políticos regionais e locais;

\footnotetext{
${ }^{29}$ Professor e pesquisador do departamento de política da Universidade de Nova York onde atualmente leciona na área da política pública.

${ }^{30}$ Professor e pesquisador da School of Public and International Affairs da Universidade de Pittsburgh/USA

${ }^{31}$ Thomas R. Dye é professor emérito de Ciência Política na Universidade Estadual da Flórida/USA
} 
descentralização administrativa, através da delegação de autoridade para os administradores públicos transformados em gerentes crescentemente autônomos; organizações com poucos níveis hierárquicos ao invés de piramidal (BRESSER-PEREIRA, 1997).

Sobre esse contexto, a cientista política Marta Arretche (2002), no artigo "Federalismo e relações intergovernamentais no Brasil: a reforma de programas sociais" mostra como foi realizada a aplicação da reforma estatal no âmbito da educação, mais precisamente em relação ao ensino fundamental e sua "descentralização" de responsabilidades e recursos.

Arretche relata que entre os anos de 1997 e 2000 houve uma redistribuição das matrículas do nível fundamental de ensino, ou seja, ocorreu uma expressiva transferência das matrículas, até então oferecidas pelos governos estaduais para os governos municipais. Segundo a cientista política, isso se deu devido a uma mini-reforma tributária de âmbito estadual, produzida pela aprovação da emenda constitucional que criou o Fundo de Manutenção e Desenvolvimento do Ensino Fundamental e de Valorização do Magistério FUNDEF (ARRETCHE, 2002).

Tal tendência seguia também determinações já expressas na Constituição Federal de 1988 estabelecendo que a oferta de matrículas no nível fundamental deveria ser universal e oferecida preferencialmente pelos governos municipais, obrigando governos estaduais e locais a gastarem $25 \%$ de suas receitas de impostos e transferências em ensino.

Para além disso, técnicos do Ministério da Educação elaboraram um projeto de emenda constitucional (sem consulta aos entes federados) que previa que, pelo prazo de dez anos, estados e municípios deveriam aplicar, no mínimo, $15 \%$ de todas as suas receitas exclusivamente no ensino fundamental. Destes recursos, $60 \%$ seriam aplicados exclusivamente no pagamento de professores no efetivo exercício do magistério. A emenda constitucional também determinava que fosse estabelecido a cada ano um valor mínimo nacional de gasto por aluno, sendo este complementado pelo governo federal nos estados onde o valor mínimo nacional não fosse alcançado (ARRETCHE, 2002).

Souza e Faria (2004), pontuam sobre a conjuntura evidenciando uma agenda não só governamental, mas sistêmica:

\footnotetext{
Naquele momento, marcado por fortes reações ao centralismo do regime autoritário e por uma grande revalorização da instância local, e apesar da pluralidade de interesses, definiu-se a tendência de atribuição de uma maior autonomia aos Municípios, confirmada, no campo da educação, alguns anos após, pela nova Lei de Diretrizes e Bases da Educação (LDB) - Lei no 9.394 -, em 1996. (SOUZA; FARIA, 2004, p. 925)
}

Assim, seguindo os princípios da reforma estatal, ocorreu na educação de ensino fundamental a descentralização do ponto de vista político 
e administrativo transferindo recursos, atribuições, serviços e autoridade para os níveis regionais e locais que, por sua vez, acataram e viram nessas políticas a oportunidade de aumentar suas receitas.

Uma vez aprovada a emenda constitucional, aumentar a oferta de matrículas na rede de ensino fundamental passou a ser uma estratégia dos municípios para obter receitas adicionais, residindo aí, em grande parte, o êxito da municipalização e o início da descentralização administrativa via parcerias público-privadas, algo que problematizaremos a seguir (ARRETCHE, 2002).

\title{
4. CONTRADIÇÕES ENTRE O CONCEITO DE POLÍTICA PÚBLICA MULTICÊNTRICA E A REALIDADE DOS MUNICÍPIOS BRASILEIROS ANTE A MUNICIPALIZAÇÃO DO ENSINO FUNDAMENTAL
}

Em que pese a rapidez e eficácia da municipalização apontada por Arretche (2002), na medida em que os municípios tiveram ampliadas suas responsabilidades e recursos, não houve ou não havia o acompanhamento de uma organização técnica-política do aparato de gestão local, o que engendrou uma ampliação de parcerias público-privadas ou até mesmo uma dependência do município junto ao setor privado:

\begin{abstract}
$\mathrm{Da}$ articulação dessas duas orientações complementares, municipalização do ensino fundamental e alterações no padrão de intervenção estatal, resultaram inúmeros arranjos políticoinstitucionais forjados pelas administrações municipais paulistas para, na melhor das hipóteses, responder às demandas educativas assumidas. Num quadro de despreparo técnico e escassez de recursos, identificados por Barreto (1988) desde os anos de 1980, uma das consequências das opções governamentais parecem apontar para a introdução de mecanismos de privatização da educação municipal.

Tal situação, ao mesmo tempo em que reflete as dificuldades enfrentadas pelas administrações municipais, apresenta-se como justificativa para a opção de políticas governamentais que se apoiam na esfera privada, subvencionando-a, em troca da transferência da lógica de organização privada para o setor público, ao invés de reverter esses recursos públicos para a melhoria e/ou consolidação do aparato governamental necessário à manutenção e ao desenvolvimento do ensino. (ADRIÃO et al, 2009, p.3)
\end{abstract}

Observamos que, no que tange a oferta de educação para o Ensino Fundamental, a política pública passa a ser multicêntrica (parceria público-privada), no entanto, decorrente não propriamente de um preparo da sociedade civil ou de um diálogo com os vários interesses e atores envolvidos no processo, como demanda teoricamente a abordagem multicêntrica.

A contradição reside no fato de que a descentralização e a multicentralidade, neste caso, não foi oriunda daquilo que na ciência das políticas públicas se considera o caminho mais "natural" para este viés: decisões/visões de baixo para cima (Bottom Up) e um planejamento estratégico participativo. Mas, ao contrário, a multicentralidade foi forjada mediante a um 
planejamento ou fluxo de decisões de cima para baixo (Top Down), mediante reforma de Estado e emendas constitucionais sem possibilidade de veto.

A consequência foi o advento de uma modalidade peculiar de descentralização administrativa com parceria público privada: aquelas firmadas entre o poder público local e empresas privadas stricto sensu, isto é, com fins lucrativos, para a compra do que se dissemina como "sistemas de ensino" (ADRIÃO2009).

Essa compra, segundo a pesquisadora Theresa Adrião (2009), representa mais do que a simples aquisição de materiais didáticos ou oferta de serviços, dado se tratar de estratégia por meio da qual o setor privado amplia seu mercado, ao incidir sobre o espaço público (aqui entendido como estatal) na mesma medida em que o setor público transfere parcela de suas responsabilidades para com a educação à iniciativa privada.

\title{
Segundo o pesquisador Carlos Roberto Jamil Cury:
}

A rigor, as políticas de descentralização, sobretudo se acompanhadas do atual modo vigente do pacto federativo, significam um repasse de responsabilidade dos escalões nacionais para os subnacionais. Se estes últimos não forem capazes de sustentar suas responsabilidades, o risco é o de haver um deslocamento do público para o privado e aí reside o risco maior de uma competitividade e seletividade, de corte mercadológico, pouco natural aos fins da educação. (CURY, 2001, p. 196)

\section{O MULTICENTRALISMO ÀS AVESSAS: Contribuição crítica da realidade brasileira ao conceito de políticas públicas multicêntricas}

Ao trabalharmos com a ideia de um conceito "às avessas", pressupõe-se a existência de um conceito clássico que funciona como um tipo ideal weberiano. A política pública multicêntrica clássica que aqui trabalhamos, foi definida em recente obra pelo professor Leonardo Secchi:

\begin{abstract}
Em geral as políticas públicas são elaboradas dentro do aparato institucional-legal do Estado, embora as iniciativas e decisões tenham diversas origens, relacionado a essa visão estão as teorias de governança pública, da coprodução do bem público e das redes de políticas públicas, em que Estado e sociedade se articulam em esquemas espontâneos e horizontais para a solução de problemas públicos. (SECCHI, 2013, p.3)
\end{abstract}

Nessa abordagem chama atenção à menção aos "esquemas espontâneos" e "horizontais", o que indica um fortalecimento e participação de atores múltiplos, porém, sobretudo, daqueles a quem as políticas públicas são endereçadas. É em razão disso que o multicentralismo surge contextualizado a processos de liberalização, descentralização e democratização:

A democracia gera condições de adensamento do tecido social, com a emergência de múltiplas formas de organização de sujeitos políticos que cobram um papel de atores na cena política. A emergência de novos atores, organizados em torno de demandas sociais insatisfeitas, tem transformado o campo das políticas sociais em um 
dos mais dinâmicos. Por outro lado, as redes nesse campo são fruto da incapacidade de qualquer dos atores, governamentais ou nãogovernamentais, em controlar $o$ processo de formação e implementação das políticas públicas e da impossibilidade de qualquer um deles controlar os recursos necessários para atender às demandas sociais. (FLEURY, 2005, p.86).

No contexto da abertura democrática brasileira, mais precisamente nos anos 1990, durante a reforma estatal, a municipalização do ensino fundamental pode ser considerada uma tentativa de desconcentração (decisões no âmbito local) e descentralização (abertura para a participação de atores diversos).

No entanto, a falta de densidade do tecido social oriundo de vinte e um anos de ditadura militar, junto ao processo de municipalização up to down da educação básica, ou seja, sem planejamento participativo, não permitiu, sobretudo, a participação de um conjunto importante de atores: os beneficiários diretos e indiretos dos serviços educacionais.

Estes, na educação, são conhecidos como órgãos colegiados tidos como fundamentais para a execução de uma gestão escolar democrática: Conselho escolar, Associação de Pais e Mestres e o Grêmio Estudantil que juntos reúnem diretores, professores, equipe pedagógica, funcionários administrativos, alunos, pais, comunidade e universidades32 (PARO, 2007).

Segundo as pesquisadoras Simone Falleiros e Tatiana Noronha de Souza:

\begin{abstract}
A importância de participar das decisões nas unidades escolares pressupõe autonomia escolar, uma gestão compartilhada com a comunidade escolar, definição de prioridades pedagógicas, físicas e de manutenção, além do gerenciamento de recursos financeiros que atendem as reais necessidades dessas unidades subsidiadas pelo Estado [...] Será na articulação da gestão com a iniciativa e a participação dos membros da comunidade escolar que a estrutura e funcionamento dessas unidades contarão com os Colegiados Escolares, cuja função básica é a de democratizar as relações de poder, intervindo de forma constante nas ações desenvolvidas e no exercício prático da gestão democrático-participativa no interior das escolas. (FALLEIROS; SOUZA, 2016, p. 306-307).
\end{abstract}

Diante da realidade subtraída de tais atores democráticos, um ator privado (com fins lucrativos) se apresentou em muitos municípios como solução para a gestão escolar e para o processo pedagógico de ensino e aprendizagem: os sistemas privados de ensino. Estes, por sua vez, e em grande medida, não contribuíram para a democratização, transparência, economia e efetividade do serviço a que o multicentralismo é associado.

\footnotetext{
${ }^{32}$ Para Vitor Paro (pesquisador da administração escolar), a administração escolar "deve envolver o maior número de pessoas, nas quais estejam representados tanto os que fazem a educação escolar quanto os que dela beneficiam".
} 
Pesquisas revelam a falta de autonomia de professores, pedagogos, gestores; falta de controle social técnico, fragilidade conceitual e pedagógica dos materiais e serviços comprados pelos municípios (mesmo tendo estes acesso aos programas nacionais de livros didáticos, configurando pagamento duplo pelo serviço); falta de descentralização/desconcentração (adequação às demandas regionais) com a submissão à lógica do lucro (mercado) e padronização/homogeneização de conteúdos e currículos escolares como parâmetro de qualidade:

\begin{abstract}
...sobre o material didático produzido pelas instituições privadas, não incide ou incide muito limitadamente qualquer forma de controle social ou técnico [...]depoimentos obtidos nas entrevistas realizadas por ocasião da pesquisa de campo indicaram serem essas aquisições opção do Executivo e, na maioria das vezes, exclusivas do próprio prefeito. Poucos sãos os Conselhos Municipais de Educação que se posicionam sobre essa decisão, enquanto os Conselhos do FUNDEF e FUNDEB, quando muito, acompanham a prestação de contas e não opinam sobre a decisão já tomada pelo Executivo [...] aspecto que nos tem mobilizado a investigar essa nova investida do privado sobre o público refere-se ao fato de que a educação pública vem sendo incorporada às estratégias de ampliação e concentração do capital privado da área educacional. Neste campo, como em qualquer esfera da sociedade capitalista, a lógica do capital é a de sua reprodução ampliada [...] A tentativa de padronização dos projetos pedagógicos e do trabalho realizado nas escolas [...] incide sobre a autonomia de escolas e docentes frente à organização do trabalho pedagógico ao retirar-Ihes, como assegura a LDB, a possibilidade de organizarem suas práticas a partir de necessidades locais ou iniciativas próprias. (ADRIÃO et al, 2009, p.807-809).
\end{abstract}

A parceria público-privada estabelecida entre municípios e sistemas privados de ensino configurou teoricamente uma política multicêntrica. No entanto, como vimos, nesta seção e na anterior, a municipalização acelerada do ensino fundamental sem pré-requisitos e sem participação ampla da sociedade gerou um efeito reverso ao pretendido pelo multicentralismo clássico na medida em que não fortaleceu atores locais e nem se configurou como serviço eficaz (econômico), muito menos efetivo (qualidade).

Se a política pública multicêntrica não se realiza materialmente, embora esteja implementada juridicamente, e, sobretudo, se o efeito de sua implementação é o reverso daquilo que se queria efetivar, o que temos é um multicentralismo às avessas.

Nada de novo em se tratando de uma realidade política e cultural já descrita por autores de peso como Roberto Schwarz como sendo a das "ideias fora de lugar" que fazem a acomodação entre ideologias e práticas contraditórias (SCHWARZ, 2000), ou, nas palavras de Sérgio Buarque de Holanda, lugar em que a democracia "sempre foi um lamentável mal entendido", "fachada" ou "decoração externa" na acomodação de privilégios (HOLANDA, 1995); ou Raimundo Faoro, para quem o pensamento político 
brasileiro, se existente, é oriundo de uma práxis que lutou para arredar da realidade a liberalização política e social (FAORO, 1987).

Isto posto, concluímos que a realidade brasileira contribuiu para a síntese de uma nova forma de política pública multicêntrica. Esta, por sua vez, um desvio oposto ao conceito original. Caminho este tomado por uma forma específica de implementação da municipalização do ensino fundamental distante da realidade dos municípios e da sociedade brasileira saídos da ditadura civil-militar, porém, que encontra bases mais profundas na estrutura do pensamento político brasileiro.

\section{INDICADORES PARA AVALIAÇÃO E ÍNDICE DE GESTÃO DEMOCRÁTICA DAS ESCOLAS MUNICIPAIS}

Diante da análise do processo de municipalização do ensino fundamental e o advento das parcerias público-privadas que incidiram em políticas multicêntricas às avessas, surge à necessidade de se criar indicadores do índice de gestão democrática das escolas municipais a fim de quantificar ou operacionalizar tal conceito. Isto, pois os resultados de políticas públicas multicêntricas às avessas, neste caso, contrariam não só o conceito clássico de multicentralismo, mas, fundamentalmente, ferem princípios estabelecidos na Constituição Federal Brasileira, mais especificamente 0 Art.206, Inc. VI; assim como as Leis de Diretrizes e Bases da Educação/1996, em seus artigos 14 e 1533.

O próprio Plano Nacional da Educação (PNE) em sua meta 1934, de maneira geral, tem por objetivo assegurar, no âmbito das escolas públicas,

\footnotetext{
${ }^{33}$ Art. 206, Inc. VI. O ensino será ministrado com base nos seguintes princípios: gestão democrática do ensino público, na forma da lei.

LDB Art. 14 - Os sistemas de ensino definirão as normas da gestão democrática do ensino público na educação básica, de acordo com as suas peculiaridades e conforme os seguintes princípios:

I. Participação dos profissionais da educação na elaboração do projeto pedagógico da escola; II. Participação das comunidades escolar e local em conselhos escolares ou equivalentes. Art. 15 - Os sistemas de ensino assegurarão às unidades escolares públicas de educação básica que os integram progressivos graus de autonomia pedagógica e administrativa e de gestão financeira, observadas as normas de direito financeiro público.

${ }_{34}$ Meta 19 prevista no Plano Nacional de Educação " assegurar condições, no prazo de 2 (dois) anos, para a efetivação da gestão democrática da educação, associada a critérios técnicos de mérito e desempenho e à consulta pública à comunidade escolar, no âmbito das escolas públicas, prevendo recursos e apoio técnico da União para tanto", tendo como desmembramento, várias estratégias para usa efetivação, dentre elas, a estratégia 19.1" priorizar o repasse de transferências voluntárias da União na área da educação para os entes federados que tenham aprovado legislação específica que regulamente a matéria na área de sua abrangência, respeitando-se a legislação nacional, e que considere, conjuntamente, para a nomeação dos diretores e diretoras de escola, critérios técnicos de mérito e desempenho, bem como a participação da comunidade escolar". Disponível em:
} 
condições para a efetivação da gestão democrática da educação, associada a critérios técnicos de mérito e desempenho e à participação da comunidade no processo de escolha de gestores escolares.

Nesse sentido, informações no que tange à: a)existência de eleições para a escolha de diretores das escolas públicas - critério de consulta pública à comunidade escolar; e b) obrigatoriedade de participação em programa de formação em gestão escolar ou realização e aprovação em prova de conhecimentos - critério de mérito e desempenho - oferece a construção do indicador:

1-Percentual de municípios que selecionam diretores de escolas públicas da rede de ensino municipal por meio de eleições e critérios técnicos de mérito e desempenho35. Ainda sobre o plano nacional da educação e a meta 19, a estratégia 19.5 estabelece o estímulo, em todas as redes de educação básica, da constituição e do fortalecimento de grêmios estudantis e associações de pais, inclusive, espaços adequados e condições de funcionamento nas escolas e fomento a sua articulação orgânica com os conselhos escolares, por meio das respectivas representações - critério de consulta pública à comunidade escolar. $\mathrm{O}$ que oferece a construção dos indicadores:

estudantil;

2- Percentual de escolas municipais que possuem grêmio

3- Percentual de escolas municipais que possuem ou têm vínculo com associações de pais e mestres;

$\mathrm{Na}$ estratégia 19.6, estimular a participação e a consulta de profissionais da educação, alunos (as) e seus familiares na formulação dos projetos político-pedagógicos, currículos escolares, planos de gestão escolar e regimentos escolares, assegurando a participação dos pais na avaliação de docentes e gestores escolares - critério de consulta pública à comunidade escolar. Oferece o indicador:

4- Percentual de escolas municipais com projetos pedagógicos desenvolvidos pela comunidade para a comunidade.

Estes quatro indicadores associados levam em consideração, ainda que de forma limitada, a presença de órgãos colegiados que contam com os âmbitos da coordenação (diretores), estudantes (grêmio estudantil) e pais e mestres (associações).

http://www.planalto.gov.br/ccivil 03/ ato2011-2014/2014/lei/13005.htm. Acesso em 03 jul.2019.

${ }^{35}$ No relatório do PNE 2018, este foi o único indicador apresentado e utilizado em avaliação. Chama atenção o fato desta meta 19 conter oito estratégias, no entanto, é a meta com menos indicadores. O site observatório do PNE, patrocinado por instituições privadas, não apresenta nenhum indicador relacionado a meta 19. 


\section{INDICADORES: Fórmula de cálculo (Abrangência Brasil e Municípios).}

Indicador 1: Municípios que selecionam diretores/as de escolas públicas da rede de ensino municipal por meio de eleições e critérios técnicos de mérito e desempenho(EMD), dividido pelo número total de municípios(TM), multiplicado por cem (Indicador 01= EMD/TM x 100).

Indicador 2: Escolas municipais que possuem grêmio estudantil (EGE), dividido pelo número total de escolas municipais(TEM), multiplicado por cem (indicador 02= EGE/TEM $\times 100$ ).

Indicador 3: Número de escolas municipais que possuem ou têm vínculo com associações de pais e mestres(EAPM), dividido pelo número total de escolas municipais(TEM), multiplicado por cem (indicador 03= EAPM/TEM $x$ 100).

Indicador 4: Número de escolas municipais com projetos pedagógicos desenvolvidos pela comunidade para a comunidade (EPC), dividido pelo número total de escolas municipais(TEM), multiplicado por cem (indicador 04= EPC/TEM x 100).

\section{CONSIDERAÇÕES FINAIS}

Tendo em vista o exposto, concluímos que, passadas mais de duas décadas da Reforma do Estado e a municipalização do ensino, o efeito democratizante que embasava teoricamente tal ação política (multicentralismo) não ocorreu. Ainda que o ordenamento teórico-jurídico de tal ação esteja dado na aparência com a desconcentração e descentralização, esta última ocorre através de uma parceria com 0 mercado que não representa um empoderamento dos profissionais e beneficiários da educação básica. $O$ que ocorreu e ocorre é uma transferência do eixo autoritário da administração escolar: do Estado para o Mercado.

Se a política pública multicêntrica não se realiza materialmente, embora esteja implementada juridicamente, e, sobretudo, se o efeito de sua implementação é o reverso daquilo que se queria efetivar em termos de exercício democrático, o que temos é um multicentralismo às avessas, conceito que aqui foi proposto como mais adequado à experiência nacional.

A fim de operacionalizar o novo conceito, apresentamos (já existente) e criamos indicadores para avaliar o índice de escolas com gestão democrática no Brasil. A partir das diretrizes de pesquisadores da área e do próprio Plano Nacional de Educação, focamos em aferir a presença dos órgãos colegiados na gestão das escolas brasileiras. A mensuração da quantidade das parcerias público-privadas relacionadas à quantidade de escolas com gestão 
democrática apresenta-se como uma maneira de verificar e avaliar o teor do multicentralismo praticado na educação fundamental.

\section{REFERÊNCIAS}

ADRIÃO, Thereza et al. Uma modalidade peculiar de privatização da educação pública: a aquisição de sistemas de ensino por municípios paulistas. Educ. Soc., Campinas, vol. 30, n. 108, p. 799-818, 2009.

ARRETCHE, Marta. Relações federativas nas políticas sociais. Educ. Soc. [online]. 2002, vol.23, n.80, pp.25-48, 2002.

BRASIL. Constituição (1988). Constituição da República Federativa do Brasil. Brasília, DF: Senado Federal: Centro Gráfico, 1988.

. Lei de Diretrizes e Bases da Educação Nacional. Lei número 9394, 20 de dezembro de 1996.

Relatório do $2^{\circ}$ Ciclo de Monitoramento das Metas do Plano Nacional de Educação - 2018. - Brasília, DF: Inep, 2018.

BRESSER-PEREIRA, Luis Carlos. A Reforma do estado dos anos 90: lógica e mecanismos de controle. Brasília: Ministério da Administração Federal e Reforma do Estado, 1997.

CURY, C.R.J. Políticas públicas: diretrizes e necessidades da educação básica. In: ENCONTRO DE EDUCAÇÃO DO OESTE PAULISTA, 3., 2001, Marília. Anais... Marília: UNESP, 2001.

DYE, Thomas R. Understanding Public Policy. Teachers College Record Volume 74 № 4, 1973.

FALLEIROS, Simone; SOUZA, Tatiana. Do discurso à prática: a gestão democrática nos conselhos escolares. In: SILVA, Hilda Maria Gonçalves da; MARTINO, Vânia de Fátima; GRACIOLI, Maria Madalena (Org.). Políticas Públicas de educação e desenvolvimento social. Curitiba: CRV, 2016.

FAORO, Raimundo. Existe um pensamento político brasileiro? Estudos avançados, vol.1 no.1. São Paulo,1987.

FLEURY, Sonia. Rede de políticas: novos desafios para a gestão pública. Administração em Diálogo, São Paulo, 2005.

HOLANDA, Sério Buarque. Raízes do Brasil. São Paulo, Companhia das Letras, 1995.

MEAD, Lawrence. M. Public Policy: Vision, Potencial, Limits. Policy Currents, Feb. Vol.1 oㅜ 4. 1995. 
PARO, Vitor Henrique. Gestão Escolar, Democracia e Qualidade de Ensino. São Paulo: Ática, 2007.

PARO, Vitor Henrique. Gestão democrática da escola pública. 3. ed. São Paulo, Ática, 2012.

PETERS, Guy. American Public Policy: Promise and Performance. Chatham, N.J. Chatham House Publishers, 1996.

PETERS, G.B.; PIERRE, J. Administração Pública: Coletânea. São Paulo: Editora UNESP; Brasília: ENAP, 2010.

SECCHI, Leonardo. Políticas Públicas: conceitos, esquemas de análise, casos práticos. $2^{\circ}$ Ed. São Paulo: Cengage Learning, 2013.

SCHWARZ, Roberto. Ao vencedor as batatas: forma literária e processo social nos inícios do romance brasileiro. Duas Cidades; Ed. 34, São Paulo, 2000.

Souza, Donaldo Bello de; Faria, Lia Ciomar Macedo. Reforma do Estado, Descentralização e Municipalização do Ensino no Brasil: A Gestão Política dos Sistemas Públicos de Ensino Pós-LDB 9.394/96. [online] Disponível na Internet via http://www.scielo.br/pdf/\%0D/ensaio/v12n45/v12n45a02.pdf. 


\title{
POLÍTICAS EDUCACIONAIS NO BRASIL: Da gênese à contemporaneidade
}

\author{
COSTA, Denise Gisele Silva \\ Doutora - UEMG \\ REIS, Lauane Silva \\ Discente - UEMG
}

\section{INTRODUÇÃO}

O desenvolvimento de um país deve ser calcado na efetivação de políticas públicas que vislumbrem a efetivação dos direitos sociais, dentre eles, tem-se de forma primordial o direito à educação pública, gratuita e de qualidade. Neste manuscrito pretende-se trazer informações necessárias para o entendimento do significado da educação para o Estado brasileiro, no qual, em seu percurso histórico apresenta avanços e retrocessos que de maneira geral opta em satisfazer o capital em detrimento das necessidades de seu povo.

Pode-se afirmar que as políticas públicas são o Estado em ação, é a partir destas que os direitos são efetivados ou negligenciados, formando uma nação desenvolvida em seu sentido mais amplo ou seu contrário, uma nação de seres domesticados e sem criticidade.

A Universidade possui um importante papel social no sentido de propulsão e socialização do conhecimento a fim de proporcionar condições efetivas para o desenvolvimento. Daí a necessidade de apoio à suas atividades de ensino, pesquisa e extensão as quais constituem seu tripé.

Com o estímulo à oferta privada de ensino superior, com políticas que beneficiam diretamente o mercado (ou seja, o capital) e ao mesmo tempo com o sucateamento das universidades públicas fragiliza-se exponencialmente a produção do conhecimento e de tecnologia do país, mantendo-o na periferia do globo. Desta forma pode-se afirmar que o desenvolvimento de um país está alicerçado em políticas efetivas de educação, ou seja, não há possibilidade real de desenvolvimento onde não se invista em educação.

\section{A EDUCAÇÃO NO BRASIL: Percurso histórico}

O sistema educacional brasileiro emerge em meio a diversas mudanças e evoluções em solo nacional, tendo seu nascimento dentro do cerne religioso trazido por seus colonizadores. Para compreender a trajetória do sistema educacional brasileiro ao longo dos séculos, faz-se necessário 
acompanhar o percurso da História, da colonização, da revolução tecnológica, do mercado de trabalho, da emancipação junto aos colonizadores, da necessidade do povo e principalmente da vontade dos políticos brasileiros.

A vinda dos portugueses e sua intenção em transformar o local até então desconhecido em colônia portuguesa, traz a religião católica por meio dos padres jesuítas para o Brasil, tendo o papel de catequizadores e propagadores de conhecimento junto aos nativos da terra, considerados sem alma e sem religião; os índios foram os primeiros da terra brasileira a passarem pelo processo educacional brasileiro.

[...] os índios não tinham a capacidade de distinguir a diferença dos diversos gestos sociais. Recebiam o impacto da colonização como uma totalidade que os retirava do seu sossego e os punha em nova situação, exigindo-lhes trabalho braçal, participação nas guerras, mudança de costumes, adesão visível à doutrina. Por isto, a catequese se Ihes tornou expressão de sua conformação com a vontade dos invasores (PAIVA, 2000, p.3).

Ao longo do período colonial, com a chegada de novas lideranças como Sebastião José de Carvalho e Melo - Marquês de Pombal, nomeado como ministro na época, algumas reformas começam a acontecer, como a reforma Pombalina a partir de 1750, os padres jesuítas são expulsos e o ensino laico ganha espaço, não sendo mais pautado na religiosidade. O acesso ao ambiente educacional era restrito para as mulheres; em algumas instituições homens mestiços eram aceitos pela obrigatoriedade imposta pelos financiadores. Aos homens brancos eram direcionadas as escolas europeias ou colégios jesuítas ainda existentes em localidades distantes.

Com a chegada da família Real ao Brasil, a vontade de transformar a colônia em local à altura para a realeza, fez com que fosse criada a primeira Escola de Medicina em 1808 na Bahia, o Jardim Botânico em 1808 no Rio de Janeiro, a Academia de Militares em 1810, a Biblioteca Real em 1810 no Rio de Janeiro, a Escola Nacional de Belas Artes em 1816 no Rio de Janeiro e o Museu Real em 1818 no Rio de Janeiro. "Como decorrência no âmbito da educação profissional, cria-se em 1809 o Colégio das Fábricas, primeiro estabelecimento do poder público no Brasil voltado à educação dos artistas e aprendizes" (CASTANHO, 2006, p.10).

$\mathrm{Na}$ velocidade em que foram realizadas as modificações dentro das cidades brasileiras com a vinda da família Real, a educação foi tomando rumos distintos, sendo pensada de maneira abrangente e com algumas nuances, até então a intenção era de que a instrução primária gratuita atingisse à toda população, entretanto algumas distinções se faziam presentes em algumas localidades, com a construção de escolas exclusivas para meninas com condições financeiras elevadas. Houve aprovação da lei sobre Ensino Elementar, bem como a tentativa do fim da proibição de acesso às escolas para a população escrava, a criação da Sociedade de Culto à Ciência e de 
diversas novas escolas de ensino religioso jesuíta, marcando seu retorno ao Brasil.

As escolas de jesuítas, especialmente os colégios e seminários em funcionamento em toda a Colônia, preenchiam perfeitamente essas funções, ajudando e assegurando dessa maneira a própria reprodução da sociedade escravocrata (NASCIMENTO, 2007, p.188).

Durante a Primeira República aconteceram reformas importantes dentro do sistema educacional brasileiro, sendo elas: Reforma Benjamin Constant em 1880 e 1881. Reforma Epitácio Pessoa em 1901, Reforma Carlos Maximiliano em 1915 e a Reforma João Alves em 1925, todas com teor de dominação dos governantes, aplicando o autoritarismo junto à população e centralizando o poder das decisões. Entre os anos de 1911 e 1915, acontece a Reforma Rivadávia onde é eximida do Estado a responsabilidade pelo ensino ofertado ao povo, têm a criação da Universidade Federal do Rio de Janeiro em 1920, paralelo a este fato em 1924 é fundada a Associação Brasileira de Educação com bases inicialmente católicas; a Universidade Federal de Minas Gerais-UFMG é criada em 1927, e, em 1932 acontecem alterações nas legislações da época onde a obrigatoriedade da oferta do ensino retoma ao Estado e a laicidade toma espaço, deixando o cunho religioso distante das ações.

\section{Oliveira, 2004, p. 952 afirma que:}

Na esfera educacional, a subida de Getúlio Vargas ao poder, na visão da Igreja, representava o fortalecimento dos ideais escola-novistas, que com a defesa do ensino laico e da escola pública colocavam em risco o predomínio das escolas confessionais.

Durante a era Vargas, a educação teve avanços de cunho modernizador, pautados nas observações feitas nos acontecimentos ao redor do mundo envolvendo guerras e desastres. Em 1930 foi criado o Ministério dos negócios da educação e saúde, que posteriormente desmembra-se e torna-se o Ministério da Educação-MEC. É instituído o Conselho Nacional da Educação em 1931 e o ensino profissional até então era direcionado para as áreas Comercial, Industrial, Normal e Agrícola, para assim atender as demandas do mercado.

[...] o grande desafio do sistema é a melhoria da qualidade do ensino para todos os níveis e modalidades da educação brasileira, prestando atenção redobrada às novas necessidades de conhecimentos e habilidades requeridos no processo de desenvolvimento econômico e social atual (CASTRO, 2009, p.696).

Para a sociedade aristocrática, em especial, para as mulheres, era permitido o acesso livre aos cursos superiores, não sendo acessível aos pobres da época. No período pós Estado Novo, já na era do Populismo, foi criada a primeira Lei de Diretrizes Básicas- LDB em 1961. Simultaneamente, as conquistas advindas dos anos anteriores, são freadas com a ditadura militar, 
iniciada em 1964, trazendo para a educação brasileira a dureza da opressão, baseada na fiscalização e na dissolução de novos ideais.

O regime militar (1964/1985) favoreceu enormemente a iniciativa privada no campo educacional. Não porque as Forças Armadas fossem espontaneamente privatistas, mas, sim, porque os agentes e colaboradores do golpe de Estado de 1964 fizeram parte ou tinham afinidades político-ideológicas com os grupos que defenderam 0 Projeto de Lei de Diretrizes e Bases da Educação Nacional (LDB), de orientação privatista, que deu origem à Lei n. 4.024, de dezembro de 1961 (CUNHA, 2007, p.811).

Disciplinas como moral e cívica foram implantadas durante a ditatura, neste mesmo período foi extinta a União Nacional dos EstudantesUNE, ambas determinações objetivavam "disciplinar" e desarticular os movimentos estudantis; ainda durante a ditadura militar em 1967 foi criado o Movimento Brasileiro de Alfabetização com 0 intuito de diminuir 0 analfabetismo entre a população adulta. Os cursos técnicos profissionalizantes que eram agregados ao ensino médio, deixam de ser obrigatórios para as instituições de ensino médio a partir de 1982 para as fases iniciais e finais; e, nestes espaços a predominância era de alunos vindos de famílias de baixa renda.

[...] desde os anos do "milagre econômico", a ampliação das camadas médias propiciou uma clientela ávida de escola privada, não só como símbolo de status prestigioso, mas, também, como alternativa para o ensino público que se deteriorava a cada ano, justamente por força das políticas elaboradas e implementadas pelos empresários do ensino e seus prepostos, que ocupavam os postos diretivos dos sistemas de educação, nos níveis federal, estadual e municipal (CUNHA, 2007, p.812).

Com a reconquista da democracia no Brasil e com a promulgação da Constituição Federal de 1988, onde a educação é comtemplada como direito social no art.6º o ensino torna-se de fato acessível para a população mais pobre, e passa a galgar passos mais largos rumo à qualidade e ao acesso generalizado. O Conselho Nacional da Educação é criado em 1995, em 2003 o Ministério da Educação passa por reestruturação e em 2007 é instituído o Fundo de Manutenção e Desenvolvimento da Educação Básica e de Valorização dos Profissionais da Educação. Dentro de todo o escopo educacional, o revestimento político fez-se presente, criando mecanismos para suas ações em consonância com os interesses de governo.

As instituições de educação infantil tanto eram propostas como meio agregador da família para apaziguar os conflitos sociais, quanto eram vistas como meio de educação para uma sociedade igualitária, como instrumento para a libertação da mulher do jugo das obrigações domésticas, como superação dos limites da estrutura familiar (KUHLMANN JR., 2000, p.11).

A educação brasileira tem novas modulações, com a criação de novas universidades, novos campus bem como o aumento de vagas para 
acesso às Universidades Públicas. Passam a existir Programas voltados para a população de baixa renda como o Programa Universidade pra Todos- PROUNI de 2005 (programa onde a população pode ter acesso a bolsas de estudos financiadas em até $100 \%$ pelo governo federal) em cursos da Rede Privada de Ensino Superior. Tem-se também o Fundo de Financiamento do Ensino Superior- FIES de 2014 (é um financiamento a longo prazo de cursos também na Rede Privada de Ensino, onde o estudante realiza o curso e posteriormente paga o financiamento ao Governo Federal). Também foi criado o Sistema de Seleção Unificada- SISU em 2010, sendo este um sistema de distribuição e acesso às vagas das Universidades Públicas em todo Brasil.

No que se refere ao repasse de verbas públicas para instituições de ensino privadas, tal política mostra-se contraditória com críticas de setores da vanguarda da comunidade científica que alegam que os recursos deveriam ser destinados à educação pública.

As entidades ligadas à educação pública alegam que os recursos trariam melhores resultados se fossem aplicados na ampliação de vagas do ensino público e, sobretudo, na sua recuperação, pois o mesmo sofreu sérias perdas de recursos [...] (LUCHESI, 2007, p. 525)

Tais programas se tornavam acessíveis após à realização do Exame Nacional do Ensino Médio-Enem, instituído em 1998. Os investimentos em atividades de ensino, pesquisa e extensão foram acontecendo de acordo com o cenário econômico brasileiro, sendo mais ou menos enxutos em decorrência do plano nacional. "No Brasil, o desenvolvimento da pesquisa está atrelado aos Planos Nacionais de Pós-Graduação e às agências de fomento" (HAYASHI, 2008, p.183).

$\mathrm{Na}$ atualidade a pesquisa no Brasil passa por um quadro de brutal desmonte com imposições de cortes destinados ao desenvolvimento, socialização e publicização de estudos científicos além de um policiamento com viés ideológico ultraconservador, o que infelizmente trará danos profundos ao desenvolvimento do país.

Esta breve contextualização do percurso da educação brasileira permitirá um melhor embasamento sobre a política de mercantilização do ensino superior e seus reflexos na precarização da educação.

\section{POLÍTICA DE MERCANTILIZAÇÃO DO ENSINO SUPERIOR: Exclusão social, desvalorização da docência e desqualificação do ensino}

Como visto anteriormente, os programas educacionais de estímulo à educação privada proporcionam um grande impulso à educação enquanto mercadoria e não enquanto direito constitucionalmente garantido, 
privilegiando o mercado e demonstrando claramente um viés neoliberal de redução de responsabilidades do Estado e terceirização dos serviços. "A política de expansão do ensino superior brasileiro é parte da reforma do Estado implementada no país, a partir da década de 1990, chegando aos dias atuais" (CHAVES, 2010, p.482).

Chaves (2010), nos coloca no cerne do processo da comercialização do Ensino Superior, pois ela acontece junto com todas as modificações pelas quais o Estado passa, o Estado como controlador das ações, exime-se de suas responsabilidades e abre todas as chancelas para que a prosperidade educacional privada aconteça; é fato que, o próprio Estado ganha com essa articulação, mantendo suas forças externas, apoio e governabilidade.

O principal marco das mudanças acontecidas no mundo do trabalho que envolveram as atividades docentes situa-se numa crise de acumulação do capital ocorrida em âmbito internacional, por volta do início da década de 1970 (BOSI, 2007, p.1505).

Com as mudanças advindas da crise do capital, com a necessidade efervescente de extrair lucros e com a abertura do nicho mercadológico de ensino privado no Brasil, especificamente do Ensino Superior, as formas de venda da força de trabalhado foram sendo alteradas. A exigência de docentes com bagagem intelectual é evidente, entretanto as condições de trabalho, a remuneração e a valorização não fazem jus à capacidade técnica dos profissionais. "Portanto, a intensificação do trabalho, a precarização, desregulamentação e flexibilização das relações de trabalho, já eram componentes cruciais na equação do desenvolvimento do capitalismo no Brasil" (BOSI, 2007, p.1506).

Os docentes brasileiros passam a trabalhar em ritmo de produção comercial, onde o produto ali produzido precisa ser entregue e ofertar retorno para a economia, quanto menos valor for produzido, menor são as chances de permanência institucional ou de aumento de remuneração. Conciliar condições precárias de trabalho, com um aprimoramento técnico, torna-se um exaustivo exercício para a permanência nos cargos.

Exemplos claros de ações vivenciadas pela docência, ditadas pelas novas regras do capital financeiro no sistema educacional são apontados da seguinte forma:

[...] o aumento insano de horas-aula, a diminuição do tempo para mestrados e doutorados, a avaliação pela quantidade das publicações, colóquios e congressos, a multiplicação de comissões e relatórios etc. virada para seu próprio umbigo, mas sem saber onde este se encontra, a universidade operacional opera e por isso mesmo não age (CHAUÍ,1999, p. 3 apud BOSI, 2007, p. 1513).

Da mesma maneira que os docentes passam por modulações nas ações e na forma de serem enxergados dentro do sistema educacional, a 
população não fica fora da conjuntura. A partir do momento em que o Ensino Superior surge como mercadoria, os discentes se configuram enquanto consumidores de um produto e não mais como alunos que buscam uma formação acadêmica para a atuação profissional posterior. "Assim, a figura do cidadão reposiciona-se para a de 'cidadão-consumidor' (caso tenha renda para consumir planos de saúde, previdência e mensalidades escolares) e 'cidadãopobre' (MOTA, 1995 apud PEREIRA, 2009, p.269).

As relações de consumo em quaisquer âmbitos, acontece quando ambos os lados ofertam algo, numa lógica de ganha $x$ ganha. Com a comercialização da educação superior, o acesso às universidades torna-se restrito apenas para aqueles que tem condições de subsidiar as mensalidades.

\begin{abstract}
No contexto da crise do desinvestimento, a mercantilização tornou-se no arquétipo da arrecadação de receitas para as instituições de ensino superior públicas, mas principalmente das privadas (WANGENGE-OUMA, 2008; MAMDANI, 2007 apud LANGA,2012, p.29).
\end{abstract}

$\mathrm{O}$ ato de comercializar o ensino superior, sendo o capital a única porta para entrada nesses ambientes, age de maneira excludente com a população; barrando assim o acesso da população pobre ao Ensino Superior, restando-Ihes a alternativa de concorrer nas Universidades Públicas, que são muito disputadas também por aqueles que possuíam um poder aquisitivo maior.

Assim, o ensino superior constitui-se como um veio extremamente lucrativo para o capital e, ao mesmo tempo, destaca-se pelo seu papel na disseminação ideológica da sociabilidade colaboracionista, através da formação de intelectuais colaboradores e empreendedores, sob a ótica do capital (Pereira, 2009.p.271).

Sob a ótica do capital, os discentes que advém das universidades, devem estar preparados para ocupar postos de trabalho, serem empreendedores, competitivos entre si de maneira que todo o resultado final seja a expansão dos lucros e a ascensão econômica dos setores. O foco de preocupação das universidades sai da ótica da politização e da cidadania, sendo voltado para a produtividade dos indivíduos.

Essa cultura da produtividade - fator da ressocialização do docente no espaço acadêmico - é transferida para os alunos da graduação e da pós-graduação que passam a receber a pressão para que sejam produtivos sob quaisquer condições. (BOSI, 2007, p.1517).

Alguns elementos ideológicos são trazidos para reforçar a preponderância da expansão sem limites do Ensino Superior Privado, justificando assim as ações que beneficiam poucos e excluí muitos, superexplorando profissionais e moldando robôs para atuação pós universidade. 
Pereira (2009) cita três bases ideológicas de uma educação útil ao capital, a primeira traz a ideia da necessidade de inclusão dos países periféricos em uma "aldeia global" através da educação; outro elemento abordado é a educação enquanto meio para a resolução dos problemas de humanidade - sem obviamente questionar a ordem do capital e a desigualdade por ele provocada, gerando a centralização da riqueza e a socialização da miséria - onde há a defesa dos organismos internacionais de que a educação superior seja realizada via ensino à distância. E finalmente, tem-se outro elemento ideológico que corrobora com as bases anteriormente citadas que é o projeto de uma "Terceira Via"

[...] cujo objetivo é, como um movimento de reação à contrahegemonia, fundar uma nova ideologia, pautada na permanência da ordem capitalista e na concepção da sociedade civil como espaço de colaboração e ajuda mútua, num explícito aclassismo (PEREIRA, 2009, p.270).

Como apontado anteriormente por Pereira (2009), algumas bases ideológicas são colocadas para que a aceitação da pulverização dos meios de se fazer dinheiro através do Ensino Superior, passe a ser naturalizado e assim que se torne comum mesmo com todos os seus contrapontos. Um item que merece destaque para ser analisado é o impulso do sistema de ensino à distância, modalidade que cai no gosto das Instituições Privadas, já que suas despesas relacionadas a pessoal são menores e sua cobertura pode ter maior abrangência.

Do ponto de vista didático-pedagógico, o ensino a distância reconfigura completamente a formação, visto que descentra a figura do professor e cria um novo sujeito: o "tutor". Outro ponto fundamental diz respeito à nula vivência acadêmica do aluno: sua formação restringe-se ao ensino "tutorial", não abarcando as dimensões fundamentais da pesquisa e extensão. Consideremos ainda a não proximidade deste aluno com movimentos coletivos, como o movimento estudantil (PEREIRA, 2009, p.274).

Alcançar novos consumidores, em localidades distantes por meio do ensino à distância, possibilitou ainda mais o fortalecimento das Instituições que atuavam em prol do capital. Entretanto, do mesmo modo que impulsionou a agudização da financeirização do ensino, precarizou ainda mais as relações de trabalho dos docentes, numa proporção que sua presença nos ambientes da Instituição já não se faz mais necessária, sendo possível prestar os serviços de casa mesmo; consequentemente tendo o valor sua força de trabalho reduzida.

A sede pelo lucro, a dominação dos espaços e a ausência do Estado na regulação das ações causou um boom econômico para estas Instituições.

[...] um sinal de que a exploração mercantil da educação se tornou um bom negócio pode ser constatado pelo faturamento apresentado pelas empresas que atuam nesse setor, que tiveram um crescimento 
significativo, de mais de $25 \%$, passando de $R \$ 44$ bilhões, em 2002, para $\mathrm{R} \$ 55$ bilhões, em 2008 (CHAVES,2010, p.494).

Singer (1996) discorre sobre dois pontos de vista com relação a educação e sob qual ângulo são defendidos, advindos de diversos atores envolvidos com o ensino desde a ponta até o lucro final.

\begin{abstract}
Vamos chamar a primeira posição de civil democrática, porque ela encara a educação em geral e a escolar em particular como processo de formação cidadã, tendo em vista o exercício de direitos e obrigações típicos da democracia. O que se contrapõe a essa visão é a que denominarei produtivista. Esta concebe a educação sobretudo escolar como preparação dos indivíduos para o ingresso, da melhor forma possível, na divisão social do trabalho. Não custa repetir que também a visão produtivista não despreza outros propósitos do processo educacional, mas enfatiza o que é chamado pelos economistas de acumulação de capital humano (SINGER, 1996, p.5-6).
\end{abstract}

Ambos os pontos colocam a educação e o sujeito como peças diferentes dentro do sistema, se contrapondo entre si e conseguindo dialogar com a colocação de Pereira (2009), tanto de maneira afirmativa, quanto de maneira contrária.

\title{
4. CONSIDERAÇÕES FINAIS
}

A mercantilização do Ensino Superior no Brasil traz sérias consequências no que tange às possibilidades reais de desenvolvimento humano e técnico, incidindo na precarização das condições e relações de trabalho dos docentes do ensino superior, na baixa qualidade do ensino e de aquisição de novos conhecimentos, uma vez que o conteúdo é passado de forma superficial sem estímulo ao pensamento crítico, e finalmente na retração do Estado diante suas responsabilidades estabelecidas pela constituição.

Desta forma, tem-se uma educação superficial e comercial que não perpassa pelo conceito mais amplo de educação, que visa a transformação da sociedade para que a mesma seja mais humana, equitativa e justa, como uma democracia deve ser.

\footnotetext{
A democratização do processo educativo deveria ir além, tratando de construir em cada escola uma verdadeira comunidade de todos os envolvidos, em que a natural superioridade dos professores e administradores fosse compensada por respeito pela vontade e pelos sentimentos dos outros membros, sobretudo dos mais jovens e mais fracos (SINGER, 1996, p.15).
}

Destarte, Singer (1996) pontua sobre a importância do respeito e da participação coletiva e efetiva dentro das instituições de ensino, mostrando que o número de instituições não é relevante quando o respeito e a participação por vontade própria não existem. "De maneira resumida, por tanto, a educação para a democracia exige conhecimentos básicos da vida social e política e uma correspondente formação ética" (BENEVIDES, 1996, p.227). 
A afirmativa de Benevides (1996), nos retrata concisamente como a educação caminha pelos variados espaços, que não se isola no aprender a ler, escrever ou desenvolver uma atividade laborativa, mas como nos possibilita fazer escolhas e exercer nossa cidadania.

Segundo Freire (1967, p. 96) "Quanto menos criticidade em nós, tanto mais ingenuamente tratamos os problemas e discutimos superficialmente os assuntos". Desta forma, demonstra-se como a criticidade, a leitura de homem e mundo e a capacidade de raciocínio nos empodera diante das dificuldades do cotidiano.

Por fim, ressalta-se que, para o Estado, a emancipação do sujeito, como formador de opinião, prejudica atitudes que visem beneficiar interesses particulares e elitistas característicos de países periféricos com uma classe política egoísta e descomprometida com o povo. A capacidade de questionamento de uma população faz com que se remodelem as estratégias de governança.

\section{REFERÊNCIAS}

BENEVIDES, Maria Victoria de Mesquita. Educação para a democracia. Revista Lua Nova. São Paulo, n.38,224-237, dez.1996.

BOSI, Antônio de Pádua. A precarização do trabalho docente nas instituições de ensino superior do Brasil nesses últimos 25 anos. Revista Educação e Sociedade. Campinas, vol. 28, n. 101,1503-1523, set./dez. 2007.

CASTANHO, Sérgio. Educação e trabalho no Brasil Colônia. In: LOMBARDI, J. C.; SAVIANI, D.I e NASCIMENTO, M. I. M. (Org.). Navegando pela História da Educação Brasileira. Revista HISTEDBR On line. Campinas-SP: UNICAMPFE: 2006.

CASTRO, Jorge Abrahão. Evolução e desigualdade na Educação Brasileira. Revista Educação e Sociedade. Campinas, vol. 30, n.108,673-697, out. 2009.

CHAVES, Vera Lúcia Jacob. Expansão da privatização/ mercantilização do ensino superior brasileiro: A formação dos oligopólios. Revista Educação e Sociedade. Campinas, v. 31, n. 111, 481-500, abr.-jun. 2010.

CUNHA, Luiz Antônio. O desenvolvimento meandroso da Educação brasileira entre o Estado e o Mercado. Revista Educação e Sociedade. Campinas, vol. 28, n.100,809-829, out. 2007.

FREIRE, Paulo. Educação como prática de liberdade. Editora Paz e Terra. Rio de Janeiro-RJ, 1967.

GENTILI, Pablo. O que há de novo nas novas formas de exclusão na educação? Neoliberalismo, Trabalho e Educação. Revista Educação e Realidade. Porto Alegre, v.20, n.1,191-202, jan. /jun.1995. 
HAYASHI, Maria Cristina Piumbato Innocentini et al. A história da educação brasileira: A produção científica na biblioteca eletrônica Scielo. Revista Educação e Sociedade. Campinas, vol. 29, n.102,181-211, jan. /abr. 2008.

HILL, Dave. O Neoliberalismo Global, a Resistência e a Deformação da Educação. Revista Currículo sem Fronteiras. v.3, n.2,24-59, jul. /dez. 2003. ISSN 1645-1384 (online).

KUHLMANN JR., Moysés. Histórias da Educação infantil brasileira. Revista Brasileira de Educação. Rio de Janeiro, n.14,5-18, maio/ago.2000.

LANGA, Patrício V. A mercantilização do ensino superior e a relação com o saber: A qualidade em questão. Revista Científica UEM, Ser: Ciências da Educação. Moçambique, v. 1, n. 0, 21-41, 2012.

LOPES, Ediane Carolina Peixoto Marques; CAPRIO, Marina. As influências do modelo neoliberal na educação. Revista Eletrônica de Política e Gestão Educacional. Araraquara, n.5,1-16, jul. /dez.2008.

LUCHESI, Martha Abraão Saad. Políticas públicas para a educação superior no Brasil no contexto sul-americano: convergências e transformações na passagem do século. In: Revista Brasileira de Política e Administração da Educação, v. 23, n. 3, p. 513-528, Set/Dez 2007.

MARRACH, Sônia Alem Neoliberalismo e Educação. Infância, Educação e Neoliberalismo. Celestino A. da Silva Jr. - M. Sylvia Bueno - Paulo Ghiraldelli Jr. - Sonia A. Marrach, 42-56 - Cortez Editora - São Paulo - 1996.

NASCIMENTO, Maria Isabel Moura. Instituições escolares no Brasil colonial e imperial. Revista HISTEDBR On line. Campinas, n.28,181-203, - ISSN: 16762584 dez.2007.

OLIVEIRA, Marcos Marques de. As Origens da Educação no Brasil Da hegemonia católica às primeiras tentativas de organização do ensino. Revista Ensaio: Avalição e Políticas Públicas em Educação. Rio de Janeiro, v.12, n.45,945-958, out. / dez.2004.

PAIVA, José Maria. Transmitindo cultura: A catequização dos índios do Brasil, 1549-1600. Revista Diálogo Educacional. Paraná, v.1, n.2,1-22, jul. /dez.2000.

PEREIRA, Larissa Dahmer. Mercantilização do ensino superior à distância e Serviço Social. Revista Katálysis. Florianópolis, v. 12 n. 2,268-277 jul./dez. 2009.

PIRES, Marília Freitas de Campos; REIS, José Roberto Tozoni. Globalização, neoliberalismo e universidade: algumas considerações. Revista Interface, Comunicação, Saúde e Educação. Botucatu, v.3, n.4, 29-39, fev.1999.

PIRES, Valdemir. Ensino superior e Neoliberalismo no Brasil. Um difícil combate. Revista Educação e Sociedade. Campinas, vol. 25, n. 86, 263-268, abril. 2004. 
SINGER, Paul. Poder, política e educação. Revista Brasileira de Educação. Rio de Janeiro, n.1,5-15, jan./fev./mar./abr. 1996. 


\title{
POLÍTICAS PÚBLICAS A SERVIÇO DO CIVILIZAR: Os excluídos da Primeira república. Franca-SP
}

\author{
SILVA, Márcia Pereira da \\ Doutora em História - UNESP \\ marciapereirasilva@gmail.com
}

\section{INTRODUÇÃO}

As políticas públicas, normalmente compreendidas como ações governamentais sistematizadas que regulam significativos aspectos da vida social enquanto ciência, estão na fronteira entre o conhecimento científico e a reflexão empírica dos organismos governamentais. É bem verdade que o senso comum atribui às políticas públicas 0 papel de promover 0 desenvolvimento social da perspectiva positiva, mas revelam, na verdade, interesses em conflito. Tais interesses estão subordinados ao tempo histórico e aos grupos em disputa.

O presente trabalho trata de pesquisa ambientalizada em um tempo histórico específico, as primeiras décadas da República no Brasil, período em que diferentes administrações locais e estaduais efetivaram políticas de higienização e saneamento social, ideia já largamente fundamentada entre os historiadores do urbano e da modernidade. Comportamentos apropriados ao homem ideal foram difundidos através da educação, seja nas escolas ou nos diferentes mecanismos do educar como a legislação, os códigos de postura, a imprensa e os órgãos de punição. Pobres, bêbados, prostitutas, imigrantes desempregados e desfavorecidos de toda ordem foram considerados não adaptados à urbe que se modernizava. Tidos como indesejáveis sociais, essas pessoas foram, por muitas vezes, alvos da política de exclusão do Estado. Este trabalho reflete sobre a política pública de saneamento da República brasileira, por meio do exemplo do Hospital Psiquiátrico Allan Kardec.

\section{PRIMEIRA REPÚBLICA, ESTADO E DESENVOLVIMENTO URBANO}

O velho Lima, personagem do conto homônimo de Artur de Azevedo, era burocrata antigo, empregado em uma das várias repartições públicas do Rio de Janeiro no ultimo quartel do período imperial brasileiro. Não tinha o hábito de informar-se. 
Adoentado, permaneceu na cama, sob os cuidados de uma "mulata" com a qual vivia, do dia 14 a 23 de novembro de 1889. Nenhuma informação teve da Proclamação da República no Brasil.

Reestabelecido, tomou o trem em direção ao trabalho no dia 23 do mesmo mês e ano. Viveu então um dia de completa estranheza: foi chamado de cidadão pelo Comendador Vidal que, aliás, Ihe disse não haver no país mais comendas; não compreendeu as pessoas se referirem à personagens imperiais pelo primeiro nome, o descaso para com D. Pedro II. E assim, sem nada entender, e também porque não estava acostumado a prestar atenção nos lugares pelos quais passava, tampouco nas pessoas que encontrava, o velho Lima chegou ao seu local de trabalho: a secretaria.

Na secretaria encontrou "um servente preto e mal trajado" que, surpreendentemente, não Ihe tratou "com a costumeira humildade", chamandoo apenas, juntamente com um aceno, "cidadão".

Era a segunda vez no dia que alguém o chamava de "cidadão", palavra que, para a personagem dessa história, pouco ou nada significava. Em seguida encontrou um conhecido republicano gabando-se de ter alçado posto de comando. E o desfecho da empreitada foi ainda mais surpreendente:

Sentou-se [o velho Lima], e viu que tinham tirado da parede uma bela litografia representando D. Pedro de Alcântara. Como na ocasião passasse um contínuo, perguntou-lhe:

- Por que tiraram da parede o retrato de sua majestade? O contínuo respondeu num tom lentamente desdenhoso:

- Ora, cidadão, que fazia ali a figura do Pedro Banana?

- Pedro Banana! - repetiu raivoso o velho Lima.

$\mathrm{E}$, sentando-se, pensou com tristeza:

"Não dou três anos para que isto seja república!"

O conto de Artur de Azevedo revela a atmosfera de estranhamento vivenciada por parcela da população do Rio de Janeiro,

O próprio formalismo linguístico e de tratamento fora substituído, mas não alcançou significado entre toda a população no mesmo ritmo do golpe que dera cabo ao Império.

Se República, cidadania, paridade social (como o tratamento do negro dispensando ao velho Lima, no conto anteriormente descrito) era uma realidade ainda não apreendida pela população do Rio de Janeiro, então capital do país, não é difícil imaginar o quão estranhos tais termos e ideias podiam parecer aos habitantes do interior do Brasil.

Artur de Azevedo, autor experimentado no ofício de registrar a realidade do mundo e da cidade que Ihe servia de abrigo, foi interprete dos novos significantes e significados das cidades que se desenvolveram nos primeiros anos da Republica no Brasil. $O$ autor teve a sensibilidade de 
perceber, como vários outros, que o comportamento dos homens nas urbes em desenvolvimento, a modernização que se anunciava e os novos papéis sociais que se impunham na forma de estranhos personagens urbanos eram temas de interesse geral, afinal, a Republica significou o advento de formas de sociabilidade que não eram, até aquele momento, comuns à subjetividade popular.

Com a República, o espaço público ganhou notoriedade, mas os homens republicanos, assim como o "velho Lima", deviam aprender a ser homens novos (O'DONNELL, 2008).

É justamente desse tema de que trata esse trabalho, ou seja, dos papéis sociais atribuídos aos homens urbanos e das várias formas de educalos para isso, sobretudo das políticas públicas de saneamento e das instituições de recolhimento e tratamento dos indesejáveis da modernidade.

\section{CULTURA POLÍTICA, DESENVOLVIMENTO URBANO E MEDICINA SOCIAL}

O que são cidades? A pergunta já mereceu inúmeros livros e tratados. Desde aqueles que consideram a passagens de burgos e vilas para 0 status de cidade até os que admitem que o termo ganha significados diferenciados para cada contexto histórico. Independentemente das concepções que possa ganhar, cidade é uma palavra que sempre carrega a perspectiva do possível, da novidade, dos aglomerados urbanos em contraposição à imagem da dispersão populacional do campo. É nas cidades que diferentes perspectivas de poder, de arquitetura, de diversão, de identidade convivem marcadas pela organização burocrática de um espaço plural, caracterizado pela promessa do possível, da inclusão e, ao mesmo tempo, da exclusão.

Consideramos a cidade como um espaço não prioritariamente tomado por plantações e criações de animais, portanto, um lugar que comporta vários tipos de produção, muitas formas de trabalho e, sobretudo, com autonomia político-jurídica para normatizar o cotidiano de seus membros. É nas cidades que a vida corriqueira é influenciada pelo tempo; não o tempo das plantações, das estações do ano, mas o tempo do relógio, das experiências coletivas, da produção exigente e julgada pela comparação com o outro.

A cidade é dinâmica, nunca estática, é múltipla em atores, cheiros, sabores...

O imaginário sobre as cidades é múltiplo, indo do medo ao fascínio; do sonho da inclusão à exclusão; da justiça ao perigo; da segurança à insegurança. Le Goff (2006, p226) fala da "utopia social urbana", construída 
ainda no medievo: a cidade como "o lugar de coabitação harmoniosa entre as classes", sob o controle da ordem pública. No entanto, a cidade é também, como lembra Sandra Pesavento (2005, p.2) lugar de "desigual apropriação do espaço, de exposição da diferença e da desigualdade social".

Nas cidades, o poder político se mostra com clareza; é neste espaço que melhor visualizamos a capacidade de ordenamento social do Estado.

A expressão ordenamento social é aqui utilizada apenas para caracterizar o Estado como um dos muitos sujeitos que disputam os espaços e o comando das urbes. As cidades estão sempre em construção, são constituídas de múltiplos espaços com diferentes significados; as cidades são viáveis para àqueles que querem se mostrar e para os que preferem o esconderijo, personagens anônimos de cantos escuros que elegem a noite em detrimento do sol. Assim, as urbes são espaços sobrepostos de disputas pelo poder, pela apropriação do espaço. Grupos competem pelo território, mas é do Estado que emana o projeto oficial de constituições das urbes, expressas na legislação nacional e estadual, nos Códigos de Posturas municipais, na imprensa, nas instituições de educação formal e nas encarregadas da alienação.

Nesse sentido, o espaço escolhido dessa reflexão é o município de Franca, embora pensar tal localidade signifique refletir sobre o assunto para todo o país.

Localizada no nordeste do estado de São Paulo, a $400 \mathrm{Km}$ da capital, Franca foi elevada de vila à categoria de cidade em 1846. Teve economia baseada na pecuária, café e em culturas como algodão, soja, arroz e milho, até que o urbano foi definitivamente marcado pelas fábricas de sapato. No entanto, é verdade a afirmação que sem a economia cafeeira a cidade não teria conhecido a modernidade e a urbanização que lhe proporcionaria, posteriormente, dedicar-se a produção de calçados.

Com o advento das ferrovias e do café o povoado cresceu, fato que resultou na evolução do artesanato que passou a produzir e fornecer chinelos e calçados rudimentares. Mas, mesmo antes da produção de calçados "tomar" a cidade, em fins do século XIX, foi mesmo o café que gerou a urbanização e determinou a modernidade e urbanização para o município.

Franca está inserida na região que acumulou capital por meio da produção cafeeira. Foi o capital oriundo do café que financiou a urbanização e o desenvolvimento do município. Os produtores mantinham suas propriedades nas imediações das vias urbanas, com as plantações, mas moravam nas cidades e nela investiam.

Isso provocou o crescimento das atividades comerciais e de prestação de serviços na cidade, assim como da população urbana 


\begin{abstract}
que, de aproximadamente sete mil habitantes em 1903, saltou para 11,051 em 1921, alcançando 18,072 moradores em 1937, e 22 mil e 1943. Vários fazendeiros cafeicultores da região, interessados em se manter mais perto das decisões políticas e dos centros econômicos mais importantes, foram paulatinamente deixando suas residências rurais e se instalando na urbe. Esses moradores mais abastados passaram a exigir da municipalidade calçamento de ruas, água encanada, rede de esgoto, iluminação elétrica, linha telefônica, jardins, teatros e hotéis. Ao mesmo tempo, procuravam também investir parte do seu capital no meio urbano, muitas vezes se aproveitando dos generosos incentivos oferecidos pelo Poder Público local à iniciativa privada para que esta provesse a cidade de alguns melhoramentos considerados vitais para a construção de uma paisagem citadina moderna (FOLLIS, 2004, p.33).
\end{abstract}

Mesmo que muitas cidades do interior de São Paulo tenham histórias de crescimento marcadas pela produção do café. $O$ município de Franca guarda duas particularidades: 1) por se tratar de cidade que não começou com o café, aqui já tinha se formado uma elite conservadora e acostumada aos valores do Império quando a urbanização teve início e; 2) como a cidade não está na região da terra roxa (usualmente conhecida como o melhor solo para o café), o local não atraiu os maiores financiamentos da região que concentraram-se na cidade de Ribeirão Preto e arredores (o que significa dizer que a novidade do bares, cabarés, teatros etc não aportou no município como em outras áreas da plantação cafeeira).

O contexto exposto anteriormente gerou, nas duas primeiras décadas do século XX, uma situação paradoxal: uma elite cafeeira enriquecida, enraizada numa política de poder local conservadora, mas ávida pelos benefícios da modernização.

Acreditamos que o fato de a formação de Franca anteceder a das cidades que nasceram por ocasião da expansão cafeeira resultou no forte apelo à tradição que marcou a elite local. Na visão da elite que vai se formando com o café, era preciso manter a antiga estrutura de dominação política que subordinava os menos favorecidos ao Estado, e simultaneamente aderir a um projeto de modernização que lhes permitissem gozar dos benefícios oriundos da modernidade, ao mesmo tempo em que garantia a aplicação do excedente do capital acumulado. O imigrante, por exemplo, geralmente ansiado no município de Ribeirão Preto, em Franca representou ameaça aos poderes locais. A cidade foi o local privilegiado do processo civilizador: "O espaço urbano aparece então como solução dupla: instrumento de aplicação do capital de uma oligarquia enriquecida com o café e local de exercício da civilidade que tal grupo pretendia" (MARTINS, 1983, p. 185).

A passagem do agrário para o urbano não ocorreu sem problemas sociais: houve o inchaço da cidade (em virtude de um número cada vez maior de imigrantes e negros libertos); o crescimento que foge ao 
inicialmente planejado, da falta de estrutura básica suficiente (água, esgoto, saúde, moradia adequada); questões, aliás, próprias do projeto civilizatório. A elite enriquecida com o café propõe a urbanização, agrega valores da modernização na cidade, ao mesmo tempo em que exclui hábitos, ideias, atrasos, pobres, pessoas mesmo. Quanto mais eficiente a política de exclusão, mais sucesso a modernização alcançará êxito aos olhos de seus idealizadores locais.

Na leitura dos Códigos de Posturas, justificados, em geral, por textos preliminares encontrados nas Atas da Câmara, e dos artigos e periódicos locais depreende-se que a elite francana não diferenciava os termos "modernidade", "modernização", "desenvolvimento" e "civilização". Todos significavam, para eles, acesso aos bens de consumo, hábitos tidos como civilizados (que incorporavam educação à mesa, ao andar, ao vestir, contrários à bebida, ao jogo), vinculados ao trabalho e à disciplina. Em resumo, a palavra modernidade estava muito presente no cotidiano da população, definida como ideal de desenvolvimento e de civilidade almejado.

Jurandir Freire Costa (1980) chama a tenção para o fato de que na medida em que as cidades cresciam, um tipo de homem afeito ao desenvolvimento e contrário aos antigos ideais do agrário começa a destacarse: homens mais intolerantes, moralistas e competitivos. Essa foi, na opinião do autor, uma elite que aproximou-se da eugenia.

A invenção da palavra eugenia é atribuída ao cientista Francis Galton, britânico que atuava na segunda metade do século XIX. Etimologicamente, eugenia significa "bem nascido"; trata-se de movimento científico-social marcado pelos possíveis benefícios" que o conhecimento sobre a hereditariedade poderia significar para a "melhor reprodução" ou, em outras palavras, para o aprimoramento das raças. Falando sobre o início do século XX, Nancy Leys Stepan (2005, p.10) afirma que é preciso considerar, para a interpretação do período, "a extraordinária atração de um movimento de reforma científica que viria a ser considerado moral e cientificamente inaceitável após s Segunda Guerra Mundial".

De qualquer modo, baseados ou não na eugenia, cresceu o papel desempenhado pela medicina nas cidades brasileiras.

A medicina social percebia que a urbanização forçava a mudança da família e que o Estado, apoiando a expansão da saúde pública, Ihe havia creditado uma certa confiança que a competia explorar até onde fosse possível (COSTA, 1999, p.113).

No entanto, a medicina social e a psiquiatria não nasceram com a política pública oficial. Segundo Robert Castel (1978, p.177) esse "não foi um aparelho centralizado que impôs sua marca de cima para baixo", aproximandose mais da ideia de "micropoderes". Explica-se: conhecimento e política foram construídos aos poucos, (re)significados ao sabor da história de cada 
localidade. Concepções de mundo, imaginários compartilhados, ações de núcleos locais de poder iam ao encontro das ambições das elites na administração do país e compuseram as políticas do Estado.

Foi nesse contexto de urbanização, de afirmação das políticas públicas de ordenamento social que cresceram, na cidade de Franca, grupos religiosos e agremiações de filantropos desejosos por atuar junto aos desprivilegiados da modernidade, a exemplo da Instituição Espírita Allan Kardec.

\section{ATUAÇÃO ESPÍRITA E MODERNIDADE: O exemplo do Hospital Allan Kardec}

Na primeira metade do século $X X$, era notória a presença de grupos religiosos em Franca, a exemplo da comunidade espírita. Espíritas e católicos disputavam poder e prestígio como membros da elite local. Um desses grupos de espíritas, por exemplo, constitui-se em torno da Fundação Espírita Pestalozzi que chegou a incorporar as escolas Pestalozzi, Unidades 1, 2, 3, diversas creches e projetos sociais financiados por uma fábrica de calçados do mesmo grupo, fazendas com produção agrícola e um observatório astronômico. Outro deles, exatamente o grupo que nos interessa para esse trabalho, respondia pelo que hoje conhecemos por FEAK - Fundação Espírita Allan Kardec.

Nos primeiros anos do século XX, José Marques Garcia construiu pequenas casas em um terreno grande que dispunha na então Rua dos Irmãos Antunes e ali acomodava doentes pobres e abandonados que circulavam pelo município de Franca. Essas pequenas casas reunidas deram origem, em 1922, ao Asilo Allan Kardec.

O asilo Allan Kardec, fundado em 1922, adquiriu personalidade jurídica em outubro de 1933, passando a ser a Casa de Saúde Allan Kardec que, em dezembro de 1972 transformou-se na Fundação Espírita Allan Kardec. A FEAK desenvolveu variadas atividades através dos anos, chegando a abarcar um Hospital, uma Clínica, dois centros espíritas, um jornal, duas livrarias e uma gráfica. Financeiramente, a maioria da verba vinha de doações e campanhas beneficentes, somada aos lucros obtidos com a gráfica, o jornal e as livrarias. Ao que parece, e segundo registros feitos pela própria instituição, só por volta do ano de 1980 é que o Hospital passou a receber dinheiro público, passando a atender as exigências dos sistemas de saúde vigentes.

Os diretores do Hospital Allan Kardec foram sempre conhecidos espíritas, como José Marques Garcia (da fundação ao ano de 1942), José Russo (1942-1980), Dijalvo Braga (1981-1995), Antônio Alberto de Almeida (de 
21 a 31 de janeiro de 1995), Eurípedes Marini (de fevereiro de 1995 a janeiro de 1999) e Dr. Eliseu F. da Mota Junior e assim por diante.

No início da Instituição a ideia era dar abrigo aos muitos pobres e andarilhos da cidade. Os desfavorecidos da modernidade incomodavam membros da população e alguns órgãos da imprensa local que clamavam por providências:

Anda pelas ruas desta cidade um negro, louco, sujeito as intempéries e ofendendo a moral pública com a sua nudez. Será bom que o Sr. Coronel Delegado mande levar esse pobre ente a São Paulo, para ser internado no Hospício de Alienados (TRIBUNA DE FRANCA, 1900, n.15)

Não foram poucos os membros da elite local a associarem etnia, condições financeiras, hábitos não consideráveis compatíveis com a civilidade, com doenças, epidemias e loucura.

Foi em resposta à situação de abandono dos menos favorecidos que respondeu o grupo de espíritas, defensores do assistencialismo, ao criar e manter o antigo Asilo Allan Kardec que posteriormente se transformaria em Hospital Psiquiátrico.

Assim, é importante ressaltar a enorme diversidade de pessoas que pela Instituição passavam. No início as pessoas procuravam por hospedagem gratuita. Era comum, por exemplo, indivíduos que viessem à cidade em busca de tratamento na Santa Casa de Misericórdia local para algum membro da família e não dispusessem de condição de permanecer no município por mais de um dia. Assim, um dos cônjuges ficava com as crianças no Allan Kardec, enquanto o outro estava internado. Após o tratamento todos voltavam para casa. Outras vezes, grupos de imigrantes não encontravam emprego e lá ficavam até que conseguissem sobreviver sozinhos ou juntar dinheiro para tomar outro destino. Há ainda registros de doentes e mendigos que se acumulavam na porta de Centro Espírita Esperança e Fé, localizado em uma das ruas centrais da cidade, em busca da caridade de terceiros e para 0 Asilo eram encaminhados, uma vez que incomodavam a estética urbana e os passeios noturnos das classes abastadas.

Com o tempo, o Asilo cresceu e passou a oferecer tratamento médico, além de comida e pouso para andarilhos. Ao adquirir personalidade jurídica e contratar especialistas foi preciso obedecer à legislação oficial: os muros cresceram, entrada e saída foram burocraticamente controladas e internos passaram a ser vigiados.

Com efeito, cientes ou não das transformações do período, o espaço que antes era de livre acesso adquiriu algumas características das Instituições de exclusão no Brasil. A elite local, antes incomodada pela ação espírita, acomodou-se à Instituição e até passou a defendê-la já que agora os 
indesejáveis da urbe tinham destino alternativo e não precisariam ser tolerados nos espaços públicos.

\section{CONSIDERAÇÕES FINAIS}

O início da República no Brasil foi um período de grande desenvolvimento urbano para homens acomodados ao universo rural e da permanência. Sobrepuseram-se várias formulações sobre o que o Brasil deveria se tornar e quais eram os cidadãos apropriados a viverem nesse novo mundo.

Esse foi um período caracterizado por muitos elementos que colaboraram para compor um universo favorável ao desenvolvimento de políticas públicas voltadas ao binômio civilizar-higienizar. Modernidade, desenvolvimento científico e da ciência psiquiátrica, urbanidade, positivismo, eugenia, urbanização e modernização encontraram-se com a ânsia humana por bens de consumo e ordem social, resultando em diferentes esforços para moldar o comportamento humano.

Mas o desenvolvimento, obviamente, também evidenciava a miséria, a ignorância atribuída àqueles que estavam afastados dos privilégios econômicos. Como esse também foi o período do crescimento dos grupos religiosos pelo interior do Brasil, no município de Franca e região formou-se uma rede assistencialista que procurava aplacar as consequências sociais da modernização. Movidos por diferentes interesses e independente de sua vontade e/ou consciência, esses grupos e suas iniciativas foram ao encontro das pretensões do Estado em civilizar e higienizar.

É imerso nessa complexa realidade que podemos compreender a Instituição Allan Kardec que acabou contribuindo para a configuração de Franca como uma cidade menos sujeita aos indesejáveis da civilização.

\section{REFERÊNCIAS}

ARQUIVO HISTÓRICO DO MUSEU MUNICIPAL JOSÉ CHICHIRI, Jornal Tribuna de Franca, 1900, n.15.

AZEVEDO, Arthur. O velho Lima. Contos de Arthur Azevedo. São Paulo: DCL, 2005, p.28-33. (Col. O Encanto do Conto)

COSTA, Jurandir Freire. Ordem médica e norma familiar. 4 ed. Rio de janeiro: Edições Graal, 1999. 
COSTA, Jurandir Freire. História da psiquiatria no Brasil: um corte ideológico. 3 ed. Rio de janeiro: Campus, 1980.

CASTEL, Robert. A Ordem psiquiátrica: a idade de ouro do alienismo. Rio de janeiro: Edições Graal, 1978. (Biblioteca de filosofia e história das ciências;4)

FOLLIS, Fransérgio. Modernização urbana na Belle Époque paulista. São Paulo: UNESP, 2004.

LE GOFF, Jacques. Verbete "Cidade". In: LE GOFF, Jacques, SCHMITT, Claude. Dicionário Temático do Ocidente Medieval I. Bauru: Edusc, 2006.

MARTINS, A. L. A invenção e/ou eleição dos símbolos urbanos: história e memória da cidade paulista. In: BRESCIANI, S. Imagens da cidade: séculos XIX e XX. São Paulo: Anpuh/ Marco Zero/Fapesp, 1983.

O'DONNELL, Júlia. De olho na rua: a cidade de João do Rio. Rio de Janeiro: Jorge Zahar, 2008.

PESAVENTO, Sandra J. Crime, violência e sociabilidades urbanas: as fronteiras da ordem e da desordem no sul brasileiro no final do século XIX. Nuevo Mundo Mundos Nuevos, Debates, 2005.

STEPAN, Nacy Leys. A hora da eugenia: raça, gênero e nação na América Latina. Rio de Janeiro: Fiocruz, 2005. 


\title{
POLÍTICAS PÚBLICAS EDUCACIONAIS EM UBERABA NO INÍCIO DA DÉCADA DE 1930: Alguns apontamentos
}

\author{
OLIVEIRA, Anelise Martinelli Borges \\ Doutora em Educação - UFTM \\ anelisemartinelli@hotmail.com \\ NASCIMENTO, Mari Clair Moro \\ Doutora em Educação - UEL \\ mariclairmoro@hotmail.com \\ VAGULA, Edilaine \\ Doutora em Educação - UEL \\ edilainevagula@yahoo.com
}

\section{INTRODUÇÃO}

A construção do sistema nacional de ensino brasileiro remonta à década de 1930, com o declínio da República Velha (1889-1930) e a ascensão de uma reorganização política, liderada por Getúlio Vargas.

Em verdade, desde a década de 1920, políticos e intelectuais adeptos da Escola Nova vinham destacando a necessidade da modernização do ensino, em detrimento das técnicas utilizadas no período monárquico, vistas como antigas e obsoletas. O discurso escolanovista trazia projetos pedagógicos respaldados na reformulação de programas de ensino em consonância com projetos que propunham formas de restruturação da sociedade brasileira e visavam:

\footnotetext{
[...] responder ao agravamento dos problemas sociais, através de diferentes propostas de controle das tensões vividas no período que passavam não só pelas relações de trabalho, mas também por problemas de moradia, saúde, higiene, alimentação, pelas tradições, pelos valores, e modos de vida; enfim, dimensões da vida social que vinham sofrendo reformulações, enfrentamentos, resistências etc. (MATE, 2002, p. 36).
}

Inserido na perspectiva de que as transformações pelas quais 0 campo educacional era palco puderam ser presenciadas tanto nas capitais dos estados brasileiros como nas cidades interioranas, o presente trabalho objetiva trazer considerações sobre as políticas públicas educacionais em Uberaba, Minas Gerais, no início da década de 1930. Para tanto, será utilizado como fonte o jornal Lavoura e Comércio, principal periódico uberabense em circulação na época. Acredita-se que a imprensa pode revelar "[...] o movimento da história (seja ele educacional, social, comercial, industrial, 
político, literário, econômico, cultural etc.) em sua dinâmica cotidiana, tal como visto por aqueles que decidem o que noticiar." (ARAÚJO, INÁCIO FILHO, 2005, p. 177). A escolha pela imprensa periódica como fonte da pesquisa ocorreu por se acreditar que o jornal é fruto da realidade social em que se encontra inserido.

O jornal Lavoura e Comércio foi fundado em Uberaba no ano de 1899 por um grupo de grandes produtores rurais e comerciantes que estavam insatisfeitos com o governo de Minas Gerais, devido às altas taxas de impostos (MENDONÇA, 1974).36 Nesse sentido, representava interesses de certos segmentos sociais.

De modo específico, o presente trabalho atenta para informações ligadas ao funcionamento das escolas públicas, à inspeção de ensino e à remodelação dos espaços escolares. Tendo em vista a compreensão da conjuntura política do período, serão utilizadas também informações referentes às ações empreendidas por Francisco Campos e Gustavo Capanema, políticos que conduziram reformas educacionais em Minas Gerais e foram, na década de 1930, ministros da educação no governo de Getúlio Vargas.

O trabalho estabelece diálogo com autores que tratam da História da Educação no Brasil, com ênfase em políticas públicas educacionais, a saber Gatti Júnior; Inácio Filho, 2005; Carvalho, 1989; Mate, 2002; Faria Filho; Vidal, 2000, dentre outros.

Serão tecidas, a seguir, considerações sobre as políticas públicas educacionais na cidade de Uberaba no início da década de 1930.

\section{POLÍTICAS PÚBLICAS EDUCACIONAIS EM UBERABA NO INÍCIO DA DÉCADA DE 1930: alguns apontamentos}

A década de 1930 representou um período de mudanças no cenário brasileiro. A chamada Revolução de 1930 - movimento armado liderado pelos estados de Minas Gerais, Paraíba e Rio Grande do Sul colocou fim à política das oligarquias e trouxe a ascensão de uma burguesia industrial. Considerado como um marco da modernização brasileira, tal período caracterizou-se pelo desenvolvimento do processo de industrialização capitalista e urbanização. Na esfera educacional, vários grupos e reformas educacionais traziam discussões sobre a função da escola como propulsora do progresso. A institucionalização do Ministério dos Negócios da Educação e Saúde, em 1930, é um exemplo das transformações pelas quais a educação escolar era palco.

Como pontua Romanelli (1999, p.59):

\footnotetext{
${ }^{36} \mathrm{O}$ jornal circulou até o ano de 2003, sendo considerado o jornal de maior circulação em Minas Gerais e o terceiro do país.
} 


\begin{abstract}
A intensificação do capitalismo industrial no Brasil, que a Revolução de 30 acabou por representar, determina consequentemente 0 aparecimento de novas exigências educacionais. Se antes, na estrutura oligárquica, as necessidades de instrução não eram sentidas, nem pela população nem pelos poderes constituídos (pelo menos em termos de propósitos reais), a nova situação implantada na década de 30 veio modificar profundamente o quadro das aspirações sociais, em matéria de educação, e, em função disso, a ação do próprio Estado.
\end{abstract}

Com efeito, discussões mais consistentes em torno da função da escola no período republicano remontam à década de 1920, com o desenvolvimento da Escola Nova, movimento de renovação escolar que se iniciou na Europa e nos Estados Unidos. A partir de um discurso pedagógico liberal, a Escola Nova instituiu novas formas de funcionamento das instituições de ensino, cujo discurso pedagógico se baseou em um modo uniformizador de educar compatível com interesses de certos segmentos da sociedade. $O$ modelo escolanovista subsidiou uma série de projetos educacionais nos estados brasileiros, e seus principais expoentes foram Sampaio Dória, em São Paulo, Lourenço Filho, no Ceará, Anísio Teixeira, na Bahia, Fernando de Azevedo, no Distrito Federal, e Francisco Campos, em Minas Gerais.

\title{
Segundo Saviani (1985, p. 14):
}

[...] a "Escola Nova" organizou-se basicamente na forma de escolas experimentais ou como núcleos raros, muito bem equipados e circunscritos a pequenos grupos de elite. No entanto, o ideário escolanovista, tendo sido amplamente difundido, penetrou nas cabeças dos educadores acabando por gerar consequências também nas amplas redes escolares oficiais organizadas na forma tradicional. Cumpre assinalar que tais consequências foram mais negativas que positivas uma vez que, provocando o afrouxamento da disciplina e a despreocupação com a transmissão de conhecimentos, acabou por rebaixar o nível do ensino destinado às camadas populares as quais muito frequentemente têm na escola o único meio de acesso ao conhecimento. Em contrapartida, a "Escola Nova" aprimorou a qualidade do ensino destinado às elites.

Os projetos reformistas propunham criação de escolas-modelo, métodos e programas, estruturação administrativa, legislação específica, reorganização funcional do professorado, onde as intervenções pedagógicas incidiriam sobre o disciplinamento social. Nesse sentido, Mate (2002, p. 41) destaca uma relação dialógica:

[...] entre a pretendida construção de um corpo social harmonioso, ordeiro e produtivo e o movimento de constituição de um sistema de escolarização que teve na apropriação das ideias escolanovistas sua principal forma de expressão e nas reformas sua concretização.

Em Uberaba, o sistema educacional também era palco de mudanças, no sentido de se adotar medidas para resolver os problemas da 
instrução pública. As discussões em torno da constituição de espaços específicos dedicados ao ensino podem ser observadas no Jornal Lavoura e Comércio de 29 de janeiro de 1931, ao noticiar que o prefeito havia realizado negociações com os proprietários dos prédios destinados aos estabelecimentos de ensino. Como boa parte das escolas municipais funcionavam em prédios particulares, a prefeitura efetuou uma espécie de parceria público-privada, tendo em vista obter melhoramentos, como reformas e limpezas. A publicação não mencionou como essa parceria se deu, mas destacou que "o entendimento" entre ambas as partes resultou em:

[...] uma sensível diminuição nessa despesa e, ainda mais, apreciáveis melhoras nos referidos prédios que, quase sem exceção, eram verdadeiros pardieiros, ameaçando ruir sobre a criançada que sob seu telhado se abrigava nas horas de estudos. Agora, com os concertos operados, todos esses inconvenientes foram removidos. (LAVOURA E COMÉRCIO, 29/01/1931, p. 2).

O trecho anterior evidenciou uma preocupação bastante comum no período: a questão da higiene nas escolas brasileiras. Para atender ao novo governo "revolucionário", era necessário adequar as instituições de ensino aos pressupostos europeizantes de saneamento e contribuir para a formação de cidadãos preocupados com a saúde e a higiene. Assim, prédios velhos e malconservados estavam na contramão das novas metodologias de ensino disseminadas pelo discurso das modernas pedagogias. Essa temática será retomada posteriormente.

No Brasil, as reformas de ensino desenvolvidas nas primeiras décadas do século $X X$ estavam atreladas às reformas na esfera social, no sentido de adequar a camada popular aos hábitos de vida e de trabalho concebidos pelas autoridades vigentes e pela elite intelectual da época. 0 período foi caracterizado por uma forte preocupação dos governos locais e federal com a educação primária. Se na década de 1910 estavam matriculados quarenta mil alunos naquela modalidade de ensino, em 1927 a educação primária contava com duzentos mil educandos. Com relação aos estabelecimentos de ensino, no ano de 1930 eram 718 as escolas mantidas pelo governo federal, 2131 escolas municipais e 1320 particulares. (BASTOS, 2005).

Em Uberaba, essas transformações também puderam ser observadas. No ano de 1931, o jornal Lavoura e Comércio noticiou realização de ações frente à ocupação de vagas, e, à contratação de novos professores, os quais deveriam ser capacitados para a função de alfabetização:

A obra administrativa da prefeitura, nesse particular, começou pelo critério severo no preenchimento das vagas existentes nas escolas. $O$ que se exigia dos candidatos ao cargo de professor municipal, foi absoluta competência e idoneidade moral para ocupar o cargo. (JORNAL LAVOURA E COMÉRCIO, 30/06/1931, p. 1). 
A reportagem ainda trazia um panorama da educação na cidade uberabense em 1931. Com o intuito de atender à demanda de alunos nas regiões urbana e rural, a prefeitura realizou a implantação de novos estabelecimentos de ensino. No primeiro semestre daquele ano, as escolas totalizavam 28, algumas das quais com funcionamento nos períodos matutino e vespertino. No que concerne aos professores, contabilizavam 34, dentre os quais se compunham de efetivos e temporários. Estavam matriculados nas escolas municipais um total de 2.527 alunos. (Idem, ibidem).

De fato, foi no ano de 1931 que o Brasil assistiu à sua primeira reforma educacional de caráter nacional, realizada pelo então Ministro da Educação e Saúde Pública, Francisco Campos. Vários decretos compuseram a Reforma, como por exemplo a criação do Conselho Nacional de Educação e a estruturação do ensino secundário.

A escolha de Francisco Campos para o cargo de Ministro ocorreu em decorrência da reforma educacional que o mesmo empreendera no estado de Minas Gerais (1927-1928), o qual, seguindo a óptica liberal da Escola Nova, pretendia disseminar a educação primária pública e gratuita para todo o estado, e, teoricamente, fundar a educação para a cidadania. Segundo Oliveira e Carvalho (2014), Campos constituía um exemplo típico da presença oligárquica num cenário liberal de governo e de educação, sendo produto da lavra de políticos e intelectuais de extração liberal da década de 1920, vindos em sua maioria da elite dirigente. Como tal, apresentava "[...] proposta de mudança coerente com a efervescência ideológica e a inquietação social ante um descompasso entre as forças sociais dominantes, a oligarquia, e forças sociais emergentes, a modernização." (OLIVEIRA; CARVALHO, 2014, p. 137).

Não obstante tinha-se a crença de que os intelectuais brasileiros estavam aptos a solucionar os problemas educacionais, o que se percebe é que muitos deles viam na política uma oportunidade de preservar sua posição social, e não um instrumento para modificar a realidade do país. Portanto, a educação permanecia voltada para os interesses das estratificações sociais mais elevadas.

As reformas empreendidas por Campos implantaram a obrigatoriedade dos "exercícios de educação física" no ensino secundário, que tinha por função, segundo a legislação da época, "[...] proporcionar aos alunos o desenvolvimento harmonioso do corpo e do espírito, concorrendo assim para formar o homem de ação, física e moralmente sadio, alegre e resoluto, cônscio de seu valor e de suas responsabilidades." (BRASIL, 1931, apud HORTA, 2012, p. 71). O documento deixava evidente a política adotada no governo varguista em relação à idealização de uma sociedade considerada saudável do ponto de vista físico e moral, onde a questão do saneamento social era pertinente à educação. 
Sucessor de Campos nas reformas educacionais em Minas Gerais, Gustavo Capanema (1930-1933) seguiu a tendência de um ensino destinado às elites e uma formação moral e disciplinadora. Juntamente com Campos, Capanema foi um dos organizadoras da chamada Legião Liberal Mineira, movimento que surgiu em Minas Gerais em 1931, cujo objetivo era apoiar o regime político surgido da Revolução de 1930 e enfraquecer as correntes políticas oligárquicas que ainda prevaleciam após a instauração do governo Vargas. Em 1933, ocupou o cargo de interventor interino naquele estado, obtendo amplos poderes para discorrer sobre a política mineira37. Tal acontecimento foi abordado pelo jornal Lavoura e Comércio:

A efetivação do atual interventor interino nesse elevado cargo é uma obra de inteira justiça. O Sr. Gustavo Capanema é um lídimo representante da cultura mineira, uma das figuras mais salientes de nossa intelectualidade e, ainda mais, uma das mais brilhantes afirmações da nova geração política mineira que surgiu disposta a reivindicar para o nosso Estado todos os privilégios e prerrogativas que no passado não the deram. (LAVOURA E COMERCIO, 04/10/1933, p. 1).

É importante salientar que o jornal Lavoura e Comércio foi amplamente favorável à Revolução de 1930, e, por consequência, apoiava a corrente legionária mineira e os políticos vinculados a ela. Enquanto periódico representado pelos "maiores fazendeiros e negociantes" uberabenses, nas palavras de Mendonça (1974, p. 83), o jornal Lavoura e Comércio se mostrava adepto dos novos arranjos políticos, vinculados à concepção de uma política destinada às elites.

Capanema, enquanto ministro da educação, defendia que a educação deveria atuar "[...] não no sentido de preparar o homem para uma ação qualquer na sociedade [...]", mas sim "[...] prepará-lo para uma ação necessária e definida, de modo que ele entre a construir uma unidade moral, política e econômica, que integre e engrandeça a Nação." (BRASIL, 1937, apud HORTA, 2012, p. 152). As medidas propostas por Capanema foram retrato da política varguista: centralizadora e excludente.

As reformas propostas por Campos, e posteriormente por Capanema, foram responsáveis por uma maior sistematização do sistema educacional brasileiro, a partir da seriação do conhecimento escolar, por meio de ciclos e séries anuais, da avaliação escolar como prática formal organizada, e, da reestruturação da inspeção no âmbito federal, afim de se estabelecer uma normatização nacional no que diz respeito à fiscalização das instituições de ensino.

A inspeção de ensino passa a ser considerada fundamental para a organização da instrução pública no início do período republicano, apesar de

${ }^{37}$ Em 1931, Getúlio Vargas regulamentou um decreto no qual exercia controle sobre as interventorias federais nos estados brasileiros, tendo em vista monitorá-los. 
existir no ensino público desde o Império (SOUZA, 1998). Cabia ao inspetor de ensino realizar visitas periódicas às escolas, fazendo recomendações, e até mesmo repreensões, tanto do aspecto administrativo/estrutural quanto do aspecto didático-pedagógico. De acordo com Ribeiro (2012, p. 60), “[...] controle, fiscalização e até punição, sempre estiveram atrelados, ao longo da história educacional, à inspeção escolar, especialmente se tratando da nacionalização". A inspeção de ensino atuava na esfera federal, estadual e local, existindo, para isso, inspetores diferentes nos referidos âmbitos.

Em Uberaba, o cargo de inspetor de ensino foi criado no ano de 1912, sendo uma função ocupada por pessoa de confiança do prefeito. Competia a esse funcionário:

\begin{abstract}
[...] apresentar à câmara [municipal] relatórios das escolas visitadas, dando conta do desenvolvimento do ensino, sugerindo medidas para o melhoramento das condições das mesmas e informando sob a capacidade moral e intelectual de cada um dos professores. As visitas deverão ser feitas duas vezes pelo menos por ano em cada escola, demorando-se em todas o tempo suficiente para bem julgálas. (LAVOURA E COMÉRCIO, 09/05/1912, p. 1).
\end{abstract}

Nesse sentido, a inspeção deveria ocorrer por meio da fiscalização das atividades a serem desenvolvidas nos estabelecimentos de ensino, em que o inspetor registraria detalhadamente aspectos concernentes ao âmbito estrutural (espaço físico, asseio) e ao âmbito pedagógico (rendimento dos alunos e práticas da equipe pedagógica, principalmente do professor). As inspeções aconteciam em instituições de ensino públicas e privadas.

No ano de 1931, foi publicado no Jornal Lavoura e Comércio o "Relatório das inspeções feitas nas escolas municipais durante o mês de outubro, pelo inspetor escolar de Uberaba, apresentado ao Prefeito Municipal." O documento trazia uma série de informações sobre as instituições de ensino, que foram classificadas em urbanas, suburbanas, rurais e distritais. De um total de vinte e oito escolas existentes no município, foram inspecionadas dez naquele mês. Em uma delas a inspeção ocorreu de modo parcial, uma vez que o professor pediu exoneração e as aulas foram suspensas. $O$ documento não trazia informações sobre a especificidade das instituições de ensino serem públicas ou particulares.

Das dez escolas inspecionadas, seis se localizavam em área considerada rural, de forma específica, em fazendas. É importante observar que, apesar das crescentes urbanização e industrialização, verificadas no Brasil a partir do início da década de 1930, a maior parte população ainda se concentrava na zona rural. Conforme se verifica em consulta ao Instituto 
Brasileiro de Geografia e Estatística (IBGE), naquele período, a estimativa da taxa de urbanização brasileira era inferior a 30\%38.

De acordo com o relatório do inspetor de ensino, boa parte das escolas possuía apenas uma sala de aula e um único professor. Isso pode ser constatado em:

A escola Cassu (rural), em data de 10 de outubro findo, ficou desprovida de professor por ter o referido professor pedido exoneração de seu cargo. [...] Escola Badajós (rural). O professor desta escola, Sr. Alfredo de Moura [...] Escola dos Carneiros (suburbana). A sala em que funciona esta escola [...]. (JORNAL LAVOURA E COMÉRCIO, 27/11/1931, p. 2)

Tal característica remonta à segunda metade do século XIX, quando as primeiras instituições de ensino uberabenses passaram a ser implementadas por iniciativas privadas de comerciantes, produtores rurais $\mathrm{e}$ Igreja Católica (MENDONÇA, 1974). Além disso, a abertura de escolas particulares era facilitada pela legislação, que, desde o século XIX não exigia licença do governo mineiro (MINAS GERAIS, 1835). Tal facilidade possibilitava o surgimento de escolas particulares, ministradas muitas vezes no próprio domicílio do professor, as chamadas casas de escola, ainda bastante comuns na década de 1930 (FARIA FILHO; VIDAL, 2000).

Outro ponto abordado no relatório de inspeção foi a estrutura física dos estabelecimentos, como se observa a seguir:

O prédio em que funciona a Escola Inocêncio Alves é cedido pelo Sr. de mesmo nome, um dos membros do Conselho Escolar, achando-se em bom estado. [...] O prédio em que funciona a Escola Santa Terezinha é bom. [...] O prédio em que funciona a Escola Joaquim Francisco de Souza é amplo e conservado. [...] O prédio da Escola São Paulo é amplo e espaçoso. [...] O prédio onde funciona a Escola Saturnino Carlos de Oliveira é espaçoso e acha-se em bom estado de conservação. [...] A sala em que funciona a Escola dos Carneiros é boa. (JORNAL LAVOURA E COMÉRCIO, 27/11/1931, p. 2).

O trecho anterior evidenciou que as descrições acerca dos espaços escolares avaliados apareceram de forma sucinta e um tanto genérica - principalmente pela ampla utilização do adjetivo "bom" nas avaliações -, não existindo advertência acerca da disposição estrutural de nenhuma escola. Com efeito, desde o início do período republicano, a escola é concebida como um espaço que deveria refletir o papel social da instrução. Segundo Souza (1998, p. 123):

\footnotetext{
${ }^{38}$ É importante observar que, na década de 1930, o levantamento e gerenciamento de dados e estatísticas sobre algumas características da população brasileira não aconteceu, apesar da obrigatoriedade de sua realização de dez em dez anos, prevista no Decreto-Lei n. 5.730, de 1929. De acordo com as informações do IBGE: "Não obstante essa previsão, motivos, principalmente de ordem política, determinaram a sua não realização nesse ano [1930]". Disponível em: https://memoria.ibge.gov.br/sinteses-historicas/historicos-dos-censos/censosdemograficos.html. Acesso em: 4 set. 2019.
} 
[...] a escola como lugar define-se juntamente com a constituição do espaço social e cultural da escola. A noção de lugar pressupõe a construção do espaço, a sua ocupação e utilização; permite compreender a estrutura física do lugar nos limites da dimensão sociocultural; nesse sentido, as formas tendem a ser físicas e humanas a uma só vez.

A questão da higiene também estava descrita no relatório, aparecendo associada ao comportamento dos alunos. É interessante observar que a avaliação do inspetor trazia uma escala de conceitos em dois níveis, "bom" e "regular": "Notei boa disciplina e bom asseio. Os alunos são disciplinados."; "Encontrei presentes [os alunos] em boa disciplina e regular asseio."; "Há boa disciplina e ordem na classe." (JORNAL LAVOURA E COMÉRCIO, 27/11/1931, p. 2). Com efeito, a preocupação com as práticas disciplinares e de higienização no âmbito educacional estava bastante presente na concepção que se tinha de educação na época, no sentido de incutir, nos alunos, hábitos saudáveis, uma vez que se considerava a escola uma extensão da sociedade.

Vale lembrar que a educação era concebida como problema de saúde pública - a própria implantação do Ministério dos Negócios da Educação e Saúde, atesta isso. Assim:

\begin{abstract}
À escola, inserida numa rede de instituições, estava reservado o papel de formar crianças e jovens, futuros cidadãos, produzindo práticas individuais e coletivas, associadas aos propósitos de constituição de sujeitos ocupados com sua higiene e sua saúde, seja pela ruptura face aos hábitos perniciosos herdados da família, seja pela conservação de práticas salutares, acrescidas de novas formas de ser e de pensar, esboçadas pelos médicos a partir da ciência e dos ideais de civilização e urbanidade (STEPHANOU, 2005, p.150).
\end{abstract}

A ocorrência da disciplina era vista como resultado das ações do professor, de modo mais específico, em como se dava sua gestão em sala, o que se verifica em: "O professor Sr. Mozart de Sales Cabeleira, é esforçado."; "A professora é muito dedicada."; "O professor é esforçado e zeloso". (JORNAL LAVOURA E COMÉRCIO, 27/11/1931, p. 2). Ao lado da aplicação da ordem e da autoridade, o professor era igualmente avaliado sobre sua prática pedagógica: "O professor desta escola, Sr. Alfredo de Moura, cumpre satisfatoriamente as exigências do programa de ensino.", evidenciando que era função da inspetoria fiscalizar a execução das normatizações impostas pelo sistema educacional (Idem, ibidem).

Com relação ao alunado, nas nove escolas inspecionadas de forma integral, vigorava o ensino com classes mistas, não existindo portanto separação por sexo. Estavam matriculados nos referidos estabelecimentos de ensino, no ano de 1931, um total de 740 alunos, sendo que a frequência no momento da inspeção foi de 481 discentes, cerca de 65\%. Assim, a taxa de alunos que não frequentaram a escola foi de $35 \%$. A razão para a ocorrência 
da infrequência, ou mesmo da evasão escolar, dava-se por alguns fatores, dentre eles o descompasso entre as necessidades das famílias e das crianças e o tempo escolar sistematizado, responsável pelo não cumprimento do horário estabelecido na escola. Isso pode ser percebido em um documento do início do século $\mathrm{XX}$, ao retratar a situação dos alunos que não chegavam no horário e/ou precisavam de sair antes do término das aulas:

\begin{abstract}
Uns meninos alegam que vão primeiro ao açougue ou fazer outras compras, outros a distância e agora no inverno alunos há que chegam até as 8 horas e meia. Quando comparecem mais cedo, pedem permissão para sair antes da hora regimental a fim de levarem almoço aos pais que trabalham. [...] a frequência de alguns não passa de fantasia. (MINAS GERAIS, 1910 apud FARIA FILHO; VIDAL, 2000, p. 27).
\end{abstract}

O rendimento escolar nos estabelecimentos de ensino foi igualmente objeto de análise do inspetor de ensino, o qual utilizou, para avaliação, escala de conceitos nos níveis "regular", "bom" e "ótimo": "Há na escola aproveitamento regular."; "Notei, nesta escola, ótimo aproveitamento."; "O aproveitamento na escola é bom." (JORNAL LAVOURA E COMÉRCIO, $27 / 11 / 1931$, p. 2). A fiscalização pedagógica se dava por meio de criterioso acompanhamento das atividades dos alunos nas diferentes escolas:

\begin{abstract}
Examinei os alunos, e notei que os seus aproveitamentos não deixam muito a desejar. [...] Revendo alguns cadernos, pude constatar que a classe tem se desenvolvido satisfatoriamente. [...] Notei aplicação nos trabalhos escolares. [...] Examinei alguns alunos e tive boa impressão de seu desenvolvimento. [...] Examinei os alunos, e notei que os seus aproveitamentos não deixam muito a desejar. [...] Os alunos são aplicados. Revi alguns cadernos e notei boa aplicação da classe. (Idem, ibidem).
\end{abstract}

Em meio às recentes conjunturas políticas, econômicas e sociais, a escola brasileira do início da década de 1930 ia se delineando. A organização do espaço escolar, o cultivo da higiene, o controle do tempo, o surgimento de metodologias específicas do processo de ensino e aprendizagem são alguns exemplos das novas formas de funcionamento das instituições escolares, em especial, das escolas uberabenses.

\title{
5. CONSIDERAÇÕES FINAIS
}

Este trabalho objetivou trazer considerações sobre as políticas públicas educacionais em Uberaba, Minas Gerais, no início da década de 1930, tendo como principal fonte o jornal Lavoura e Comércio, periódico uberabense em circulação na época. A escolha da imprensa periódica como fonte da 
pesquisa ocorreu por se acreditar que pode revelar importantes aspectos do âmbito educativo.

A análise do periódico e o diálogo com autores que tratam da temática - pesquisadores inseridos no campo da História da Educação -, permitiu compreender o cenário educacional uberabense no que tange ao funcionamento das escolas públicas, à inspeção de ensino, à remodelação dos espaços escolares, e, às ações implementadas por Francisco Campos e Gustavo Capanema, políticos que conduziram reformas educacionais em Minas Gerais e foram, na década de 1930, ministros da educação no governo de Getúlio Vargas.

Os resultados indicaram que as informações contidas no jornal Lavoura e Comércio vão ao encontro das políticas públicas educacionais implantadas no restante do país, no que diz respeito às novas formas de funcionamento das instituições escolares. A sistematização do ensino verificada na própria institucionalização do Ministério dos Negócios da Educação e Saúde em 1930 -, trouxe uma nova concepção de educação alicerçada em pressupostos civilizatórios europeizantes e representada, dentre outros, pelos materiais pedagógicos, espaços e tempos escolares, regulações comportamentais (tanto do aluno quanto do professor).

Assim, a presente pesquisa se mostrou relevante por tentar compreender a perspectiva que se tinha acerca das políticas públicas, dos processos educativos e das práticas escolares, os quais vigoravam não apenas na cidade de Uberaba, como também no Brasil no início da década de 1930.

\section{REFERÊNCIAS}

JORNAL LAVOURA E COMÉRCIO. Uberaba/MG. Edição do ano de 1912: 09/05. (Arquivo Público de Uberaba).

JORNAL LAVOURA E COMÉRCIO. Uberaba/MG. Edição do ano de 1931: 29/01, 30/06, 27/11. (Arquivo Público de Uberaba).

JORNAL LAVOURA E COMÉRCIO. Uberaba/MG. Edição do ano de 1933: 04/10. (Arquivo Público de Uberaba).

ARAÚJO, José Carlos Souza Araujo; INÁCIO FILHO, Geraldo. Inventário e interpretação sobre a produção histórico-educacional na região do Triângulo Mineiro e Alto Paranaíba. In: GATTI JÚNIOR, Décio; INÁCIO FILHO, Geraldo (orgs.). História da educação em perspectiva: ensino, pesquisa, produção e novas investigações. Campinas: Autores Associados; Uberlândia: Edufu, 2005. 
BASTOS, Maria Helena Câmara. A Revista do Ensino do Rio Grande do Sul (1939-1942): o novo e o nacional em revista. Pelotas: Seiva, 2005.

FARIA FILHO, Luciano Mendes; VIDAL, Diana Gonçalves. Os tempos e os espaços escolares no processo de institucionalização da escola primária no Brasil. Revista Brasileira de Educação, maio/jun./jul./ago.2000, n.14, p.19-34.

HORTA, José Silvério Baia. O hino, o sermão e a ordem do dia. Campinas: Autores Associados, 2012.

MATE, Cecília Hanna. Tempos modernos na escola: os anos 30 e a racionalização da educação brasileira. Bauru: EDUSC; Brasília: INEP, 2002.

MENDONÇA, José. História de Uberaba. Uberaba: Academia de letras do Triângulo Mineiro. Bolsa de publicações do Município de Uberaba, 1974.

MINAS GERAIS. Lei 13, de 28 de março de 1835. Regula a criação das Cadeiras de Instrução primária, o provimento e os Ordenados dos Professores. Disponível em:http://www.almg.gov.br/consulte/legislacao/completa/completa.html?tipo=LE I\&num $=13 \&$ comp $=\& a n o=1835 \&$ aba $=$ is textoOriginal Acesso em: 01 set. 2019.

OLIVEIRA, Pâmela Faria; CARVALHO, Carlos Henrique. Educação e modernização em Minas Gerais: propostas reformistas na ação conservadora (1926-1930). Revista História da Educação, Porto Alegre, v. 18 n. 42, jan. labr. 2014, p. 131-150. Disponível em:

http://www.scielo.br/pdf/heduc/v18n42/08.pdf. Acesso em: 26 ago. 2019.

RIBEIRO, Ester Rosa. Políticas públicas nacionais em educação entre 1930-1945: A inspetoria municipal de educação de Rio Grande - RS. 2012, 122f. Dissertação (Mestrado em Educação). Universidade do Vale do Rio dos Sinos: São Leopoldo, 2012.

ROMANELLI, Otaíza de Oliveira. História da educação no Brasil. 23. ed. Petrópolis: Vozes, 1999.

SAVIANI, Dermeval. Escola e Democracia. São Paulo, Cortez, 1985.

SOUZA, Rosa Fátima. Templos de civilização: a implantação da escola primária graduada no Estado de São Paulo (1890-1910). São Paulo: UNESP, 1998. 
STEPHANOU, Maria. Discursos médicos e a educação sanitária na escola brasileira. In: STEPHANOU, Maria; BASTOS, Maria Helena Camara (org.). Histórias e memórias da educação no Brasil: século XX. Petrópolis: Vozes, 2005. 


\title{
POLÍTICAS PÚBLICAS, EDUCAÇÃO E DIREITOS HUMANOS: o Memorial da Resistência de São Paulo
}

\author{
CAMPOS, Guilherme Pires de \\ Mestrando - Unesp Franca \\ gp.campos@unesp.br
}

ROSA, Lilian Rodrigues de Oliveira Rosa Pós-doutora em Administração das Organizações - FEA-USP Ribeirão Preto Irrosa@faap.com.br

\section{INTRODUÇÃO}

O cenário político brasileiro passa por um processo de revisionismo histórico do golpe de 1964 e de disputas pela memória do período. A ordem do presidente da república Jair Bolsonaro (PSL) dada ao Ministério da Defesa, para comemorar os 55 anos do regime militar provocou, no dia 31 de março, uma sequência de atos e protestos em todo país. De um lado estavam os apoiadores da ditadura. De outro, grupos ligados a defesa dos direitos humanos e familiares de mortos, desaparecidos durante o governo dos militares.

Tal efeito revela um movimento de esquecimento promovido nas últimas três décadas pelo Estado, na tentativa de varrer os traumas do passado, em nome de uma memória nacional. Entretanto, como uma bomba relógio, quem experienciou o trauma de forma conjunta está sempre pronto a romper o silêncio e trazer à tona o passado. Por isso, este passado que retorna não é o mesmo que passou, é um
passado renovado à luz dos problemas enfrentados no presente, das
lutas e das reivindicações do presente. É o momento em que vêm à
tona "esquecimentos" que foram politicamente provocados para
emudecer, enfraquecer a luta de hoje, silenciar grupos sociais
dispostos à superação da situação de opressão. (FERRAZ, 2006, p.
3)

Como palco dessa arena de conflito estão prédios, avenidas e praças carregados de memórias, que marcam a resistência à repressão. $O$ antigo Destacamento de Operações de Informações - Centro de Operações de Defesa Interna (DOI-CODI), na Vila Mariana em São Paulo, é um exemplo. Criado para combater opositores, passaram pelo departamento milhares de presos políticos. Inclusive hoje uma das reivindicações desses grupos é a transformação do local em memorial. 
Enquanto o antigo DOI-CODI ainda passa por um processo de reconhecimento da necessidade de sua preservação enquanto um lugar de memória (NORA, 1993), há uma década o Memorial da Resistência de São Paulo (MRSP) se consolida como representante de uma política de memória. Inaugurado em 2009 depois de décadas de embates entre grupos de pressão e o Estado, o memorial se dedica basicamente à preservação de referências de memórias vivas da resistência, a partir da musealização de parte do prédio onde funcionou o Departamento Estadual de Ordem Política e Social de São Paulo (Deops/SP).

O espaço, gerenciado por equipe especializada sobre a tutela da Associação Pinacoteca Arte e Cultura, organização social que tem contrato de gestão com a Secretaria da Cultura do Estado, preserva as celas onde ficaram presos políticos, traz uma exposição permanente com fotos, testemunhos orais em vídeo, promove pesquisa e as ações educativas com foco nos direitos humanos. Esta pesquisa se dedica à olhar mais atentamente para este último eixo.

O programa educativo tem objetivo de formar cidadãos críticos e sensibilizar o público para a cidadania, a necessidade do aprimoramento da democracia e do respeito aos direitos humanos.

Enquanto instituição que recebe recursos públicos, por isso uma política pública, nos chama a atenção o fato de que a facilitação do acesso e a divulgação da existência do memorial está proporcionalmente ligado ao alcance das metas e seus objetivos. Ocorre que nesses últimos dez anos de funcionamento percebe-se um aumento da procura de professores e estudantes do ensino público e privado pelo tema. Observa-se, diante do contexto político atual trazer novamente à tona as disputas pela memória da ditadura, a necessidade do reforço de uma educação que se volte para formar uma sociedade igualitária, que preze pela dignidade humana e sobretudo democrática.

$\mathrm{Na}$ falta de uma educação formal estruturada nesses princípios, reforça-se o papel do MRSP, que oferece de graça atividades pedagógicas em direitos humanos para todos os níveis de escolaridade, a partir da própria história política recente do Brasil republicano, do lugar musealizado e das memórias de seus interlocutores.

Neste artigo, portanto, apresentamos a evolução do plano de ação do programa "Visitas Educativas" em números, com base nos relatórios de metas elaborados e divulgados pela APAC, e uma análise prévia da efetividade desta política. Entretanto, é preciso ressaltar que os resultados mostrados são parciais, parte de pesquisa ainda em andamento, no programa de mestrado em planejamento e análise de políticas públicas pela Unesp Franca. 


\section{POLÍTICAS DE MEMÓRIA}

As políticas de memória no Brasil surgem através de ações pontuais ao longo das últimas três décadas, dentro de um contexto de necessidade de reparação de vítimas que tiveram seus direitos humanos violados, em crimes cometidos durante a ditadura civil-militar (1964-1985). A desigualdade de forças entre os cidadãos e o sistema instaurado, que promoveu a censura, perseguições, torturas, desaparecimentos e mortes, levou parte da população a resistir contra a repressão. Mas durante a transição para a democracia, as demandas pela preservação das memórias dessas "culturas minoritárias", como denominou Pollack (1989), acirraram a arena de disputas pela memória, que permanece ainda hoje.

A mobilização de atores sociais, como entidades não governamentais, partidos políticos, grupos ligados aos direitos humanos e outras instituições para a garantia do registro, acesso e divulgação das memórias do período militar no Brasil, dão força ao conceito de "memória coletiva", cunhado por Halbwachs (2006). Para o autor, na tarefa de compreender a si mesmo, o sujeito se recria e os pares se procuram ao redor de um acontecimento. Os próprios espaços onde os crimes aconteceram, como os quartéis, delegacias, faculdades, largos e cadeias são o ancoradouro dessas memórias.

Todos eles podem ser definidos como Nora (1993) denominou de "lugares de memória", por agregarem a memória coletiva de um fato histórico geralmente traumático. Para o autor, o lugar de memória só pode ser assim denominado se contemplar três aspectos: o material, o funcional e o simbólico. Material por sua demografia, funcional por cristalizar a lembrança e simbólico por caracterizar experiências vividas. No sentido de identificar e preservar esses lugares se inserem as políticas públicas de memória.

Para Gumieri (2012), tais políticas são estabelecidas principalmente em programas e atividades oferecidas em memoriais e centros de memória, que têm como proposta social levar a conhecimento público as experiências do passado para o cotidiano atual. O meio para isso se dá através da coleta e registro de testemunhos orais, documentação histórica recolhida e ações para o exercício da cidadania, democracia e respeito aos direitos humanos.

Entretanto, a inciativa memorialista por parte do Estado ocorre tardiamente no Brasil. Na medida que ex-presos políticos, familiares de mortos, desaparecidos forçados e de organizações de direitos humanos demandavam o direito à memória no pós-ditadura, foi estabelecida o que alguns autores chamam de uma política de esquecimento. 
Nos anos finais da repressão, "virar a página", no sentido de esquecer um trauma e deixar pra trás o que passou, foi um objetivo propagado pelo governo, ou seja, uma política de Estado. A lei n․ . 6.683, de 28 de agosto de 1979, do então presidente João Batista Figueiredo, concedeu anistia a todos que cometeram crimes políticos (1961-1979), como também beneficiou parte dos presos políticos que tiveram seus direitos cassados. Diante dos aparatos legais, tentou-se apagar os rastros das violações dos direitos humanos cometidos pelos agentes da ditadura.

Esse esquecimento induzido deu-se, sobretudo, através de
estratégias como o não acesso a documentos, a fim de impedir que
parte dessa memória fosse restaurada, com vistas a pedidos de
justiça e de indenização (BRITO; FERREIRA, 2012, p. 198).

Só a partir da década de 1990, o Estado propôs o que Napolitano (2015) chamou de um conjunto de "leis-memória". Em 1995, a lei 9.140, do governo de Fernando Henrique Cardoso, criou a Comissão Especial de Mortos e Desaparecidos. Este é o primeiro reconhecimento, por assim dizer, da necessidade de reparação às vítimas, como parte da agenda de prioridades do governo. Apesar disso, não foram criados instrumentos de responsabilização dos autores.

As ações avançaram em 2002, com a lei 10.559 que institui a Comissão de Anistia do Ministério da Justiça. Ali foi estabelecida uma política de reparação econômica em caráter indenizatório, para anistiados políticos vítimas da ditadura civil-militar. Em 2005 um marco importante nas políticas de memória foi a transferência dos arquivos do então Serviço Nacional de Informações (SNI) para a Casa Civil, que passou a ser de domínio público no Arquivo Nacional. Avançando um pouco na cronologia, outro passo que vem sequência deste, foi a lei de acesso à informação 12.527 de 2011, já no governo de Dilma Roussef (PT), que garantiu a transparência total de arquivos públicos à sociedade, inclusive os referentes à ditadura civil-militar, possibilitando o aparecimento de novas memórias.

Em 2008 o Arquivo Nacional fechou acordo de cooperação técnica com 28 instituições para a implantação de uma política pública de integração em rede de acervos. O resultado disso, por uma inciativa da Casa Civil, foi a criação do projeto "Memórias Reveladas - Centro de Referência das Lutas Políticas, 1964-1985", um banco de dados com informações dos arquivos participantes, para colocar na internet registros sobre as lutas políticas durante a ditadura. Além dos documentos da SNI, outros conjuntos documentais da guarda do Arquivo Nacional também podem ser consultadas, como os acervos do Deops/SP, do qual falaremos em seguida, da Comissão Geral da Investigações (CGI) e do Conselho de Segurança Nacional (CSN).

Em 2009, pelo decreto 7.037, do governo de Luís Inácio Lula da Silva, foi criado o Programa Nacional de Direitos Humanos, o PNDH-3, onde 
em seu $6^{\circ}$ eixo orientador, o Estado estabelece três diretrizes fundamentais para a formulações de políticas de memória: reconhecimento da memória e da verdade como direito humano da cidadania e dever do Estado; preservação da memória histórica e construção pública da verdade; e a modernização da legislação relacionada com promoção do direito à memória e à verdade, para o fortalecimento da democracia (BRASIL, 2009).

Em 2011 foi instituída a Comissão Nacional da Verdade (CNV), pela lei 12.528, que tinha como objetivo esclarecer violações de direitos humanos, torturas, mortes e desaparecimentos, a identificação de seus autores, estruturas e locais durante a ditadura, promover audiências públicas, assim como a recomendação de medidas e políticas públicas de não repetição.

O relatório final da CNV, publicado em 2014, recomenda 29 medidas importantes, entre elas a proibição de comemorações oficiais do golpe de 1964 e o incremento de uma política de preservação da memória durante a repressão. 434 mortos e desaparecidos políticos 361 agentes de Estado responsabilizados. "A conclusão, já apontada pela pesquisa historiográfica anterior, é que estas violações não constituíram "exceções", como sugeria o discurso oficial do regime e sim uma política de Estado integradas e sistemática" (NAPOLITANO, 2015, p. 25).

\section{O MEMORIAL DA RESISTÊNCIA DE SÃO PAULO}

O MRSP hoje ocupa o prédio onde funcionou, entre 1942 e 1983, - Departamento Estadual de Ordem Política e Social de São Paulo (Deops/SP), uma das polícias políticas mais truculentas do Brasil republicano.

O edifício foi construído em 1914, no Largo General Osório, no 66, como parte do conjunto ferroviário da conhecida Estação da Luz. Em 1939 foi reformado para abrigar o Deops/SP, instituído como forma de controle e repressão ao movimento anarquista, movimentos de greves por parte do operariado e da fundação do Partido Comunista Brasileiro (PCB) em 1922. De acordo com Neves (2012), isso também levou as classes políticas à criação de um "aparato administrativo de vigilância" em diversos estados. A coordenação em nível federal cabia ao Departamento de Ordem Política e Social (DOPS). 0 aparato legal para coibir crimes dessa natureza foi a criação da lei nํㅗ 38 , de abril de 1935, de Segurança Nacional. O Deops/SP serviu tanto ao período autoritário de Getúlio Vargas, persistiu no período democrático e se fortificou na ditadura civil-militar, quando, segundo Gumieri (2012), intensificou estratégias de repressão e enfrentamento contra grupos de resistência, como prisões ilegais, torturas e mortes.

Com a extinção do Deops/SP, em 1983, o prédio passou a ser sede da Delegacia do Consumidor. Em 1998, depois da forte pressão social de 
familiares de presos políticos, mortos e desaparecidos, assim como entidades ligadas aos direitos humanos e do poder público, a administração do prédio passou das mãos da Secretaria da Justiça para a Secretaria da Cultura. Em 1999 houve o tombamento do edifício pelo Conselho de Defesa do Patrimônio Histórico do Estado de São Paulo (Condephaat), através da Resolução SC 28/99.

Nesse mesmo ano, 2002, o governador Geraldo Alckmin publicou o decreto no 46.508, que criou no mesmo endereço onde funcionou 0 Deops/SP, com administração da Secretaria da Cultura, o "Memorial do Cárcere". Pela primeira vez o Estado reconhece a importância de preservar símbolos da resistência à repressão e traça como objetivo estimular a cidadania e seus valores democráticos, por meio de manifestações culturais. No dia 5 de julho daquele mesmo ano, outro decreto, de $n^{0} 46.900$, mudou 0 nome para "Memorial da Liberdade", diante da ideia de promoção dos direitos humanos e da liberdade. Em 20 de janeiro de 2004, o decreto no 48.461 instituiu o edifício como parte integrante da Pinacoteca do Estado, que passou a ser denominado "Estação Pinacoteca.".

Qualificada no final de 2005 como Organização Social de Cultura, a Associação Pinacoteca Arte e Cultura (APAC), assumiu a partir de 2006, através do decreto $n^{\circ} 50.941$, de 5 de julho, a gestão do museu. No artigo $2^{\circ}$ ficou instituída a formulação de diretrizes e promoção da preservação da memória do Estado. Nesse contexto, o "Memorial da Liberdade" passou a ser chamado "Memorial da Resistência de São Paulo".

Em 2009 o MRSP consolidou-se com a implantação do projeto museológico e passou a se dedicar com mais ênfase para preservar as referências da resistência e da repressão políticas. Entre as atividades desenhadas estão rodas de debates, seminários, exposições permanentes e temporárias, pesquisa, coleta de testemunhos orais do período, levantamento de lugares de memória em todo o Estado de São Paulo, ações educativas e cursos de formação sobre direitos humanos.

Como destaca Gumieri (2012), a intenção memorialista parte, em princípio, da ação do Estado, que é o tomador de decisão e implementador desta política. Apesar disso, o MRSP é uma solução criada para resolver um problema público, que só passou a fazer parte da agenda do governo a partir de uma demanda social. A criação do memorial assegura "o direito a resistir, às utopias, à revolução e às liberdades democráticas, além de repudiar o estado de exceção, a repressão e os crimes de lesa humanidade, a partir da visão das vítimas" (NEVES, 2012, p. 3).

Heidemann (2014) define que "toda ação de mudança praticada na sociedade por força de lei ou por regulação pública é política pública, independentemente de serem públicos ou privados seus agentes implementadores" (p. 33). A política pode ser analisada partir de duas 
perspectivas: estatista ou multicêntrica. A primeira parte da prerrogativa de que o Estado é o principal interventor para promoção do bem-estar da sociedade. A elaboração de leis, programas e destinação de recursos são, portanto, monopólio de agentes do Estado. Já a abordagem multicêntrica leva em consideração outros atores sociais, como organizações privadas, ONGs, comunidades e redes de políticas públicas. As decisões nessa perspectiva são elaboradas dentro do aparato legal, mas de forma horizontal, sendo que Estado e sociedade se articulam em conjunto.

Entende-se, portanto, que o Memorial da Resistência de São Paulo em si mesmo é uma política pública planejada e implementada dentro de uma abordagem multicêntrica, já que parte de uma demanda social, atende a um problema público (o direito à memória), foi instituída por decreto e envolve diversos atores em sua implementação, como a Secretaria da Cultura de São Paulo, que destina recurso público, e a APAC, organização social que gerencia o dinheiro e atividades, através de metas, e as executa em contrato de gestão. Essa política segue o modelo de planejamento bottom up, de baixo para cima, uma vez que a sociedade tem participação fundamental. Mas ela não está pronta e acabada. "Nesse modelo, o formato que a política pública adquiriu após a tomada de decisão não é definitivo, e a política pública é modificável por aqueles que a implementam no dia a dia" (SECCHI, 2017, p. 61).

\section{EDUCAÇÃO EM DIREITOS HUMANOS}

O Plano Nacional de Educação em Direitos Humanos (PNEDH) de 2006 é a principal política de Estado para a construção de uma sociedade baseada na cidadania, igualdade, democracia e uma cultura da paz. Trata-se de uma série de diretrizes, definidas pelo resultado da articulação da sociedade civil organizada, organismos internacionais, instituições de ensino e governo, que norteiam a elaboração de políticas públicas, para promoção de uma educação de qualidade para todos.

O debate ganhou relevância pós-ditadura civil-militar, como resposta à violência social e política, praticadas no período. Em 1988 a Constituição Federal consagrou o estado democrático de direito, o que trouxe ao país o estabelecimento de tratados internacionais e reconhecimento da jurisdição da Corte Interamericana de Direitos Humanos. Durante os anos 1990, as ações não governamentais pela proposição de políticas de fortalecimento da democracia ganharam força. Diante disso, a participação da sociedade cresceu na formulação de propostas e diretrizes, por meio de conferências e criação de conselhos em todas as esferas.

A Lei de Diretrizes e Bases ํo 9.394 de 1996 prevê o exercício da cidadania como uma das finalidades da educação. Resultado direto da LDB foi 
o surgimento do conceito de cidadania ativa, que "engloba aspectos inspirados em valores humanistas, embasados nos princípios da liberdade, igualdade, equidade e diversidade" (BRASIL, 2007, p. 23).

O PNEDH de 2006 compreende educação em direitos humanos como a formação de consciência cidadã, o fortalecimento de práticas que promovam a reparação de violações e apreensão de conhecimentos históricos. O plano traz diretrizes para a educação formal, do ensino básico ao superior, formação de professores e educação não-formal, eixo que esta pesquisa se apoia. Nesse sentido, a educação não-formal deve ser vista como:

\begin{abstract}
a) mobilização e organização de processos participativos em defesa dos direitos humanos de grupos em situação de risco e vulnerabilidade social, denúncia das violações e construção de propostas para sua promoção, proteção e reparação; b) instrumento fundamental para a ação formativa das organizações populares em direitos humanos; c) processo formativo de lideranças sociais para 0 exercício ativo da cidadania; d) promoção do conhecimento sobre direitos humanos; e) instrumento de leitura crítica da realidade local e contextual, da vivência pessoal e social, identificando e analisando aspectos e modos de ação para a transformação da sociedade; f) diálogo entre o saber formal e informal acerca dos direitos humanos,
\end{abstract}

integrando agentes institucionais e sociais; g) articulação de formas educativas diferenciadas, envolvendo o contato e a participação direta dos agentes sociais e de grupos populares. (BRASIL, 2017, p. 44)

A prática da educação não-formal em direitos humanos se dá pelos movimentos sociais, ONGs, entidades, partidos políticos e museus, que levam a reflexão sobre os direitos civis, políticos, econômicos, sociais e culturais. O Memorial da Resistência de São Paulo se enquadra nesse escopo.

O plano museológico do memorial está estruturado em três grandes eixos: pesquisa, salvaguarda (documentação e conservação) e comunicação patrimoniais (exposição e ação educativo-cultural). Uma das linhas programáticas é a Ação Educativa que desenvolve atividades que busca contribuir com a formação de cidadãos críticos e "sensibilizar sobre a importância do exercício da cidadania, do aprimoramento da democracia e do respeito aos direitos humanos" (MEMORIAL DA RESISTÊNCIA DE SÃO PAULO).

O plano prevê: a) formação de educadores; b) visitas educativas mediadas para escolas públicas e particulares; c) seminários; d) produção de apoio à prática pedagógica escolar; e) programações temáticas ligadas a datas históricas do calendário oficial.

As "Visitas Educativas" são o contato mais direto de estudantes da educação formal com o tema, já que eles podem ver as antigas instalações do Deops/SP, entrar nas celas onde ficaram presos políticos, ouvirem os relatos gravados e reproduzidos em televisores de vítimas da violência do Estado e participar de uma roda de conversa com pesquisadores e guias do 
memorial, ao redor do acervo fotográfico da exposição permanente. As visitas duram cerca de 1 h15 e precisam de agendamento prévio.

\section{O PROGRAMA "VISITAS EDUCATIVAS" EM NÚMEROS}

Mas como saber se o programa "Visitas Educativas" de fato tem contribuído para uma educação em direitos humanos? Para isso é preciso medir a efetividade desta política.

A avaliação de uma política pública é "a atividade instrumental para a geração de informações importantes para a manutenção, os ajustes ou a extinção de política públicas" (SECCHI, 2017, p.10). Para se avaliar o cumprimento dos objetivos e 0 andamento de uma política pública, a construção de indicadores é necessária para medir quantitativamente e qualitativamente os resultados.

De um lado, indicadores instrumentalizam as demandas de grupos organizados em partidos políticos, sindicatos, associações patronais, imprensa e outras instituições; de outro, oferecem aos técnicos e gestores uma representação estruturada passível de ser avaliada comparativamente com outras demandas concorrentes. (JANUZZI, 2017, p. 3)

A construção de um sistema de indicadores sociais, para Januzzi (2006), segue os seguintes passos: 1) definição da temática a que se refere; 2) a forma de interpretação operacional desse conceito; 3) obtenção de estatísticas públicas; 4) combinação das estatísticas para composição de indicadores.

Os indicadores podem medir a eficácia, eficiência e efetividade de uma política. De forma resumida, de acordo com o IPEA (2018), os indicadores de eficácia mostram se o que foi prometido foi entregue, se os produtos foram entregues no prazo determinado. Os de eficiência, se foi possível reduzir os custos e os de efetividade se a missão está sendo cumprida, se os resultados estão dentro da meta. Para se desenvolver uma avaliação, o primeiro passo está na seleção de dados disponíveis e definidos previamente, "antes da execução de uma intervenção" (IPEA, 2018, 104).

A Associação Pinacoteca Arte e Cultura (APAC), organização social que gerencia os recursos do Estado para a Pinacoteca do Estado e o Memorial da Resistência de São Paulo, anualmente publica um relatório de resultados e prestação de contas em sua página na internet39. Para cada atividade foi estabelecida uma meta a ser alcançada e um indicador de mensuração.

\footnotetext{
${ }^{39}$ http://apacsp.org.br/contrato-de-gestao/auditoria/
} 
Apesar de o MRSP ter começado suas atividades em 2009, seu plano museológico só foi implantado no mês de setembro, por isso os dados passaram a ser compilados e apresentados nesse formato de relatório a partir do ano seguinte. Assim sendo, montamos uma tabela da série histórica entre os anos 2010 e 2018 que mostra a evolução da atividade e abaixo descrevemos as justificavas apresentadas para cada um dos anos. Os números destacados em verde demonstram um resultado positivo e os em vermelho resultado abaixo do esperado.

Quadro 1 - Metas e resultados do programa Visitas Educativas do Memorial da Resistência de São Paulo. Série histórica de 2010 a 2018.

\begin{tabular}{|llll|}
\hline \multicolumn{5}{|c|}{ Memorial da Resistência de São Paulo } \\
VISITAS EDUCATIV AS \\
\multicolumn{4}{|c|}{ Realizado } \\
2010 & 10.000 & 11.814 & Percentual \\
2011 & 12.000 & 16.081 & $118 \%$ \\
2012 & 15.000 & 24.140 & $134 \%$ \\
2013 & 14.000 & 19.058 & $161 \%$ \\
2014 & 14.000 & 17.106 & $136 \%$ \\
2015 & 10.500 & 13.111 & $122 \%$ \\
2016 & 10.500 & 12.574 & $125 \%$ \\
2017 & 10.500 & 10.165 & $120 \%$ \\
2018 & 10.000 & 12.185 & $97 \%$ \\
Total & 106.500 & 136.234 & $127 \%$ \\
\hline
\end{tabular}

Fonte: APAC

\section{ANÁLISE DE RESULTADOS PARCIAIS}

Em 2010, a meta estabelecida para receber alunos da rede pública e privada foi superada em $18 \%$. Além de ser novidade, tal resultado se deve à parceria com o Núcleo de Preservação de Memória Política do Fórum dos Ex-presos e Perseguidos Políticos do Estado de São Paulo. Ocorre que tal 
parceria resultou na divulgação das atividades do memorial, o que contribuiu para atração do público.

Em 2011 percebe-se um aumento significativo de público no programa, totalizando 34\%. Importante notar que a instituição aumentou a meta de um ano pro outro. Um dos motivos foi a parceria entre inciativa privada e 0 Ministério da Cultura, do Governo Federal, por meio de lei de incentivo e de patrocínio de empresas parceiras.

Em 2012, terceiro que foi possível a mensuração de tais indicadores, o programa atingiu o maior índice de sua série histórica, tendo a meta superada em $61 \%$. Aqui a meta estipulada também teve aumento e se comparado com o ano de 2010 de 50\%. A instituição relata um repentino aumento do interesse de público escolar, não só dos ensinos fundamental e médio, como também de universitários e outras instituições de ensino. O que intriga nesse ano é que não há um motivo aparente.

O ano de 2013, o percentual de crescimento cai, mas mesmo assim se mantém em patamares maiores do que em relação aos dois primeiros anos o programa passou a ser medido. Aumento considerável de $36 \%$, provocado também pela grande procura de instituições de ensino e o incremento da atividade "contação de histórias", que atraiu público infantil. Entretanto é preciso registrar que a meta estabelecida caiu em mil pessoas em relação ao ano anterior.

Em 2014 a meta de visitas recebidas durante o ano se manteve e também foi superada em $22 \%$. Os conteúdos trabalhados nas escolas referentes à ditadura militar levaram alunos ao memorial, somados aos esforços de professores em conseguir ônibus para transporte desses estudantes, são explicações para o sucesso do programa. Importante notar que em relação a 2012 há um declínio de público constante.

No ano de 2015 o número de visitantes esperados cai drasticamente e o índice volta quase aos estabelecido em 2010. Em números totais o total de visitantes recebidos também diminui, mas ainda assim a meta foi superada, praticamente mantendo quase a mesma curva percentual em relação ao ano anterior. Ocorre que neste ano $60 \%$ de todas as visitas recebidas deveriam ser exclusivamente de escolas públicas, numa tentativa de estímulo aos estudantes enquadrados nessa categoria. Além disso, o contrato com a Fundação para o Desenvolvimento da Educação (FDE) foi rompido neste ano. Daí se explica a diminuição da meta estabelecida. Ainda assim, ações de comunicação foram tomadas para diminuir o impacto do cancelamento de agendamentos previamente marcados, tendo no fim resultado positivo.

Em 2016 a meta estipulada se mantém em relação ao ano anterior e há ligeira queda nas visitas realizadas. Entretanto este é um ano 
chave na série histórica, quando se olha para as visitas educativas. Apesar do arrefecimento de parcerias e dificuldade financeiras das escolas que impediram a saída de diversos grupos para visitas ao memorial, a instituição intensificou a divulgação de suas atividades. Essa ação foi somada a um contexto político que despertou interesse ao tema ditadura civil-militar. Este foi o ano do processo de impeachment da presidenta Dilma Roussef (PT), que foi quem sancionou a Comissão Nacional da Verdade e vítima histórica de torturas durante o regime. Importante registrar que durante votação na Câmara dos deputados pelo impedimento do exercício da então presidente, o então deputado Jair Bolsonaro (PSL) hoje atual presidente da república, exaltou a figura do General Brilhante Ulstra, acusado de ser torturador de Dilma e de tantas outras vítimas. Esse contexto político despertou o interesse de estudantes sobre o assunto, provocou discussões, o que levou bastante gente ao memorial.

No ano de 2017 a meta foi mantida, entretanto pela primeira vez na série histórica não foi cumprida, ficando 3\% abaixo do esperado. Entre os motivos está o cancelamento de visitas agendadas por parte de escolas, pela falta de recursos para transporte de alunos no terceiro trimestre. Na tentativa de reduzir o impacto, a APAC disponibilizou por meio de captação de recurso, via PROAC ICMS e parceria com a Secretaria Estadual de Educação, transporte escolar de graça para os estudantes.

As incertezas do ano anterior fizeram o memorial reduzir ainda mais a meta de visitas, voltando em 2018 aos patamares iniciais de 2010. Mas ainda assim, o índice estipulado foi superado em $22 \%$. Novamente neste ano 0 contexto político foi a força motriz para o sucesso do programa. $O$ ano eleitoral e a retomada das disputas pela memória, promovidas pelo então candidato à presidência Jair Bolsonaro (PSL), ataques aos direitos humanos, às vítimas da ditadura despertaram 0 interesse das instituições de ensino pelo memorial. Além disso, o contrato com o FDE e a volta dos recursos proporcionou novos agendamentos de escolas.

\section{CONSIDERAÇÕES FINAIS}

No que diz respeito ao programa "Visitas Educativas", o Memorial da Resistência de São Paulo atende ao objetivo estabelecido de fortalecimento dos direitos humanos e da democracia, ao promover o acesso de alunos escolas públicas e privadas ao acervo, exposição e debates sobre o tema a que ele se dedica. Dentro do escopo do que compreende o PNEDH de 2006, a entidade contribui para a formação de um cidadão ativo, através da educação não-formal, ao oferecer atividades complementares ao conteúdo programático do currículo escolar. 
Está claro nos números apresentados e nas justificativas pesquisadas, que a variação dos resultados se dá em função do contexto político e que, apesar disso, a procura pelo tema é constante. A efetividade da política se dá também pela disponibilidade de recursos para o transporte destes estudantes, principalmente das escolas públicas, estabelecido por meio de parcerias com instituições e o governo de São Paulo.

Portanto, o Memorial da Resistência de São Paulo é parte importante na promoção de uma educação em direitos humanos no país ao mostrar que é preciso um planejamento detalhado para a proposição de atividades e acompanhamento de seus resultados. Já que os desafios ainda são muitos, o envolvimento das instituições de ensino com entidades como o MRSP é um caminho sólido para uma cultura de paz.

\section{REFERÊNCIAS}

BRASIL. Plano Nacional de Educação em Direitos Humanos. Brasília: Secretaria Especial dos Direitos Humanos, Ministério da Educação, Ministério da Justiça, UNESCO, 2009.

BRASIL. Decreto no 7.037, de 21 de dezembro de 2009. Aprova o Programa Nacional de Direitos Humanos - PNDH-3 e dá outras providências. Brasília, 2009. Disponível em: <http://www.planalto.gov.br/ccivil 03/ Ato20072010/2009/Decreto/D7037.htm>. Acesso em: 26 jun. 2019.

BRASIL. Lei no 9.394, de 20 de dezembro de 1996. Estabelece as diretrizes e bases da educação nacional. Disponível em: <http://www.planalto.gov.br/ccivil 03/leis//9394.htm>. Acesso em: 01 set. 2019.

BRITO, Ana Paula Ferreira; FERREIRA, Maria Letícia Mazzucchi. A patrimonialização de lugares de sofrimento: o direito à memória e à verdade sobre o regime militar no Brasil (196-206). In. MICHELON, Francisco Ferreira; MACHADO JÚNIOR, Cláudio de Sá; GONZÁLES, Ana María Sosa (Org.). Políticas públicas e patrimônio cultural: ensaios, trajetórias e contextos. Pelotas: Ed. da Universidade Federal de Pelotas, 2012. Disponível em: $<$ https://wp.ufpel.edu.br/ppgmp/files/2016/11/Pol\%C3\%ADticasP\%C3\%BAblicas-do-Patrim\%C3\%B4nio-Cultural.pdf >. Acesso em: 24 jun. 2019.

FERRAZ, Joana D`Arc Fernandes. A Ditadura Militar no Brasil: as disputas pela memória. XII Encontro Regional de História. Rio de Janeiro: ANPUH, 2006.

GUMIERI, Julia Cerqueira. O Memorial da Resistência de São Paulo: reparação simbólica e ações preservacionistas. Histórica - Revista Eletrônica do Arquivo Público do Estado de São Paulo, São Paulo, no 54, p 1-11, jun. 2012. 
HALBWACHS, Maurice. A Memória Coletiva. São Paulo: Centauro, 2006.

HEIDEMANN, Francisco. Do sonho do progresso às políticas de desenvolvimento. In: HEIDEMANN, Francisco; SALM, José. (org). Políticas públicas e desenvolvimento. Bases epistemológicas e modelos de análise. Brasília: Editora UNB. 3 ed. 2014.

IPEA. Avaliação de políticas públicas: guia prático de análise ex ante. Vol. 1. Casa Civil da Presidência da República, Instituto de Pesquisa Econômica Aplicada. Brasília: Ipea, 2018. Disponível em: $<$ https://www.cgu.gov.br/Publicacoes/auditoria-e-fiscalizacao/arquivos/guiaanalise-ex-ante.pdf>. Acesso em: 11/06/2019.

JANUZZI, Paulo de Martino. Indicadores sociais no Brasil: conceitos, fontes de dados e aplicações. 3. ed. Campinas: Alínea, 2006.

Indicadores no ciclo de políticas e programas sociais no Brasil. In: SIMÕES, André; ALKMIN, Antônio Carlos. (org.) Indicadores sociais: passado, presente e futuro. Rio de Janeiro: IBGE, 2017.

MEMORIAL DA RESISTÊNCIA DE SÃO PAULO. Página inicial. Disponível em: <www.memorialdaresistenciasp.org.br/memorial/>. Acesso em: 15 jun. 2019.

NEVES, Deborah Regina Leal. Memoriais das ditaduras: a memória em exposição em São Paulo e Buenos Aires. Anais Eletrônicos do X Encontro Internacional da ANPHLAC, p 1-15, São Paulo, 2012.

NEVES, Kátia Regina Felipini. Memorial da Resistência de São Paulo: uma perspectiva museológica processual. In: FERREIRA, Maria Letícia Mazzuchi; MICHELON, Francisca Ferreira. (org). Pelotas: Ed. da Universidade Federal de Pelotas, 2012.

NAPOLITANO, Marcos. Recordar é vencer: as dinâmicas e vicissitudes da construção da memória sobre o regime militar brasileiro. Antíteses, Londrina, v. $8, \quad$ n. 15, p. 9-45, nov. 2015. Disponível em: $<$ http://www.redalyc.org/articulo.oa?id=193343056003>. Acesso em: 24 jun. 2019.

NORA, Pierre. Entre Memória e História: a problemática dos lugares. In: Projeto História. São Paulo: PUC, n. 10, 1993.

POLLACK, Michael. Memória, esquecimento, silêncio. Estudos Históricos, Rio de Janeiro, v. 2, n. 3, p. 3-15, 1989.

SECCHI, Leonardo. Análise de políticas públicas: diagnóstico de problemas, recomendação de soluções. São Paulo: Cengage Learning, 2017. 


\title{
UMA ANÁLISE DE DADOS COLETADOS NAS UNIVERSIDADES SOBRE RELACIONAMENTOS ÍNTIMOS ABUSIVOS
}

\author{
MARCICO, Bianca \\ Mestranda - UNESP \\ PINCA, Marcela Helena Petroni \\ Mestranda - UNESP
}

\section{INTRODUÇÃO}

A priori cabe pontuar que o presente artigo é derivado de um projeto mais amplo, originado da experiência empírica das autoras, enquanto estudantes, mulheres e universitárias. Dessa maneira, o estabelecimento da restrição ao âmbito das universidades, primeiramente, se deve ao fato da proximidade com tal ambiente e com a percepção de negligência das instituições, públicas e privadas, frente às violências de gênero, inquietações estas que foram atestadas pela pesquisa empírica realizada.

No Brasil, atualmente, doze mulheres são mortas por dia vítimas de feminicídio40, ou seja, doze mulheres são mortas por dia simplesmente pelo fato de serem mulheres. Em que pese esses números alarmantes, um dos principais obstáculos na prevenção de violências contra as mulheres, quando estas possuem uma relação íntima com o agressor, é a dificuldade que a vítima tem em romper o ciclo do abuso, o que se dá por diversas razões de matriz social e psicológica. Buscou-se, através da coleta de dados elaborada de forma anônima e com enfoque também na subjetividade dos relatos, apurar o modo pelo qual esse ciclo de agressão se perpetua.

Embora os dados coletados não nos permitam realizar uma análise geral e dedutiva, entende-se que, nestes casos, a análise qualitativa se apresenta como um dado empírico importante, pois apresenta uma realocação do local de fala dessas vítimas, que deixa de ser contado por outros e passa a ser, por elas, relatado, em uma instância que não apresenta os caracteres formais opressivos, como as delegacias de polícia e o poder judiciário, os quais podem apresentar influências nos relatos.

O contexto da pesquisa foi escolhido em virtude de alguns critérios dessa população específica, quais sejam: mulheres relativamente jovens, com um grau de instrução formal considerado alto, porém em situação de vulnerabilidade quanto ao gênero e quanto a estrutura de redes de apoio, pois que, geralmente, inseridas em um ambiente diverso do qual estavam acostumadas.

\footnotetext{
${ }^{40}$ Para maiores dados consultar: http://especiais.g1.globo.com/monitor-daviolencia/2018/feminicidios-no-brasil/. Acesso em 06 set. 2019.
} 
$\mathrm{Na}$ Universidade, geralmente, a autonomia da(o) aluna(o) é aumentada consideravelmente, se comparada a das(os) alunas(os) do ensino médio, quando estas saem das suas cidades e adentram o universo da carreira que optaram seguir. Todavia, não se pode prescindir do fato de que não há um período de transição e os jovens entram de maneira abrupta, geralmente, em contato com realidades diferentes das que vivia até então. As repúblicas, os apartamentos, as pensões, entre outros, são um ensaio para a "vida adulta", os quais nem sempre trazem apoio suficiente para esses estudantes. Nesse ponto, a Universidade poderia ser visualizada como a figura institucional a quem se recorria em momentos de dificuldade, no entanto, conforme se apurou, a realidade é bastante diferente.

Propõe-se que a Universidade, enquanto espaço de desenvolvimento humano integral, voltada à educação e à promoção da evolução da coletividade, seja também um lugar que possibilite a essas jovens um ambiente de igualdade e aprendizagem que permita a participação saudável dessas mulheres no ambiente universitário, por meio da proteção e do apoio da própria instituição à integridade física, psicológica e mental das universitárias, repudiando violências.

O trabalho busca abordar duas frentes, preventiva e repressiva, dando ênfase à primeira, na medida em que parte-se da percepção de que a proteção dos direitos das humanas deve, assim como quaisquer direitos humanos, ser respeitado e resguardado não só a partir da etapa pós-violatória, mas, principalmente, antes das violências ocorrerem, ou seja, numa perspectiva pré-violatória (RUBIO, 2015).

A conscientização de atitudes abusivas e violentas praticadas em um relacionamento abusivo e o acolhimento da mulher vítima de tal relacionamento, ouvindo seus relatos e dando suporte para que esta mulher encerre o ciclo de violências, é imprescindível para que ela não deixe de frequentar espaços, como a própria universidade. Isto pode acontecer pelo medo do agressor, que em muitas situações está na mesma universidade, ou de possíveis discriminações que ela possa sofrer pela estrutura patriarcal que revitimiza a mulher que sofreu violências, colocando-a como culpada e colocando o agressor como vítima de supostas acusações, na medida em que há toda uma estrutura misógina que naturaliza uma série de violências e impõem às mulheres se submeterem a elas, colocando-as sempre como foco do julgamento ao invés dos agressores (SAFFIOTI, 2004).

Cumpre dizer que a maioria das pessoas não percebe a complexidade de um relacionamento abusivo, na medida em que, de fora e isento dos sentimentos e fatos ocorridos dentro da relação, elas já conseguem captar os "sinais" de uma relação abusiva e, assim, ao invés de dar amparo à essa mulher vítima, a culpabilizam pela permanência na relação. Os relacionamentos abusivos não se iniciam diretamente com a violência, sendo 
muitas vezes mascaradas por atitudes calmas e pacientes por parte do agressor, as quais não são as mesmas daquelas atitudes perpetradas dentro da relação quando já estabelecido o vínculo de confiança do casal. Mesmo que com diferentes peculiaridades é formado um ciclo de violências, no qual há "agressão - desculpas - lua de mel - agressão" (ALBERTIM e MARTINS, 2018:6).

O estudo visa apurar dados aptos à elaboração de uma proposta de política pública - institucional, que abranja os aspectos da identificação e rompimento desse ciclo do relacionamento abusivo, por parte dessas mulheres. De outro lado intenta-se aumentar essa percepção, por parte daqueles que estão ao redor dessa mulher, de como agir e acolher essa mulher, sem expô-la a mais risco e agressões ou culpabilizá-las.

\section{DESCRITIVO DA METODOLOGIA}

A pesquisa foi feita por meio da ferramenta digital "Google Forms", através da elaboração de um questionário cujo preenchimento ocorreu de forma anônima, contendo perguntas objetivas e dissertativas. Para a validação dos dados não se solicitou a confirmação de e-mail ou CPF, pois se considerou que tais solicitações poderiam inibir as participantes em razão de se tratar de um assunto bastante delicado, posto que inserido numa sociedade patriarcal e misógina. Assim, primou-se pela garantia às pesquisadas, da sensação de anonimato a fim de se conseguir uma satisfatória descrição das situações de vulnerabilidade vividas, inclusive com a superação das cifras ocultas da violência de gênero[1].

Dada a escolha feita pelas pesquisadoras existe a possibilidade de algumas respostas terem sido dadas em duplicidade, todavia o foco primordial da pesquisa se trata de uma análise qualitativa dos relatos para, além de se apurar a existência de situações de violência, se pensar em mecanismos à sua redução e garantia de proteção às vítimas. Não se busca uma construção estatística, mas sim, uma análise de casos, eis que "São os dados da pesquisa empírica que estruturam o desenvolvimento do trabalho. [...] Nas ciências sociais, a realidade não se sujeita a coisa alguma. A realidade fala; a realidade se apresenta; e cabe ao pesquisador, apenas, explicitá-la." (BAPTISTA, 2008: p. 16).

Para a divulgação do questionário elegeu-se 0 método snowball[2], com disseminação iniciada nas redes sociais das autoras, através do Twitter, Facebook e WhatsApp, tendo sido solicitado àquelas que tiveram acesso ao formulário que encaminhassem a outros grupos de mulheres universitárias. Os resultados indicam maior participação de mulheres em Universidades do Estado de São Paulo, especificamente da UNESP, fato já 
esperado em decorrência do ponto inicial de disseminação do formulário, pois as autoras são alunas da UNESP - Campus de Franca.

A publicação inicial do questionário foi feita em 01.05.2019 e recebeu a primeira resposta às 18:21:11 daquela data. A última resposta foi colhida em 13.05.2019, às 16:05:54, quando atingiu o total de 550 respostas. $O$ questionário se manteve aberto a respostas até 09.07.2019, quando foi finalizado, para fins de se elaborar a presente comunicação. O limite da disseminação, por meio da metodologia utilizada, se deu em um período de 13 dias, com o alcance de 511 mulheres que estudaram em 104 Universidades[3], 18 Estados[4] e 5 Países[5].

\section{RESULTADOS APURADOS}

O questionário foi pensado especificamente para a pesquisa referente a violências cometidas contra mulheres em relações íntimas de cunho afetivo ou sexual, dentro do ambiente universitário. A validação dos dados desprezou cerca de $8 \%$ das respostas colhidas, pois não se enquadraram dentro dos parâmetros propostos, no caso, mulher que foi ou é estudante universitária, correspondendo ao total de 511 respostas, das 550 colhidas. Quanto ao uso do vocábulo "mulher", não se explicitou a diferença entre mulheres cisgênero e transgênero, utilizando-se apenas os vocábulos: mulher, homem e outro.

Colacionamos os resultados das Universidades nas quais mais de 10 mulheres responderam às perguntas, indicando-se pela ordem: Universidade Estadual Paulista (UNESP) 163 respostas; Universidade de São Paulo (USP) 68 respostas; Universidade Federal do Estado de São Paulo (UNIFESP) 25 respostas; Universidade de Campinas (UNICAMP) 22 respostas; Faculdade de Direito de Franca FDF 21 respostas; Universidade Federal de São Carlos (UFSCAR) 19 respostas; Pontifícia Universidade Católica (PUC) 13 respostas; Universidade Federal do Rio Grande do Sul (UFRGS) 13 respostas.

Proporcionalmente a Universidade em que se apuraram mais casos de violência, dentre as que se obteve mais de dez respostas, são: Faculdade de Direito de Franca FDF 71,43\%; Pontifícia Universidade Católica (PUC) 69,23\%; Universidade Federal do Estado de São Paulo (UNIFESP) 68\%; Universidade Federal de São Carlos (UFSCAR) 57,87\%; Universidade Estadual Paulista (UNESP) 45,4\%; Universidade de São Paulo (USP) 38,23\%; Universidade de Campinas (UNICAMP) 36,36\%; Universidade Federal do Rio Grande do Sul (UFRGS) 15,38\%.

Em complemento, foram apresentadas caixas de seleção com a descrição das violências elencadas pela Lei Maria da Penha (Lei no 11.340/06), solicitando-se assinalar as que houvessem sofrido. Optou-se pela junção das 
violências psicológica e moral dada a tênue linha de separação entre o conceito informado por ambos e a fim de facilitar a compreensão pelas pesquisadas[6]. O texto contido nas caixas de seleção foi o seguinte: A Violência Física (agressão, empurrão, tapas, socos...) ; B - Violência Sexual (estupro, sexo forçado, beijo forçado, recusa em usar preservativo...) ; C Violência Psicológica e Moral (xingamentos, ameaças, perseguições, humilhações...) ; D - Violência Patrimonial (destruição total ou parcial de bens, objetos, controlar os seus gastos...).

As respostas foram correlacionadas com as orientações sexuais declaradas pelas mulheres, do que se têm:

Tabela 1 - Respostas

\begin{tabular}{|l|l|l|l|l|}
\hline Espécie de violência Relatada & TOTAL & \multicolumn{3}{|l|}{ Declarou se relacionar com: } \\
\hline & & Homens & Mulheres & Os dois \\
\hline Física & 2 & 1 & 0 & 1 \\
\hline Física e Psicológica/Moral & 18 & 10 & 1 & 7 \\
\hline Física, Psicológica/Moral e Patrimonial & 11 & 7 & 2 & 2 \\
\hline Física e Sexual & 2 & 2 & 0 & 0 \\
\hline Física, Sexual e Psicológica/Moral & 17 & 15 & 1 & 1 \\
\hline Todas as violências descritas & 7 & 5 & 0 & 2 \\
\hline Patrimonial & 3 & 1 & 1 & 1 \\
\hline Psicológica/Moral & 93 & 65 & 4 & 24 \\
\hline Psicológica/Moral e Patrimonial & 7 & 7 & 0 & 0 \\
\hline Sexual & 30 & 22 & 0 & 8 \\
\hline Sexual e Patrimonial & 1 & 0 & 1 & 0 \\
\hline Sexual e Psicológica/Moral & 52 & 39 & 0 & 23 \\
\hline Sexual; Psicológica/Moral e Patrimonial & 6 & 3 & 0 & 3 \\
\hline
\end{tabular}

Sobre a busca por algum tipo de rede de apoio, a pergunta foi feita com as seguintes opções: A - Familiares; B - Amigas ou amigos; C Centro Acadêmico; D - Psicóloga/Psiquiatra; E - Delegacia de Defesa da Mulher; F - Universidade; G - Judiciário; H - Advogada/o. As opções foram elencadas em forma de caixas de seleção, com a possibilidade de se assinalar as opções aplicáveis. Inferiu-se que as maiores redes de apoio procuradas foram, pela ordem: Amigos, Psicóloga ou Psiquiatra, Familiares, Universidade 
ou Centro Acadêmico, Delegacia de Defesa da Mulher e Advogada. Nenhuma mulher procurou o Poder Judiciário.

Também se buscou perceber qual a sensação de acolhimento e segurança que as mulheres que foram em busca de ajuda conseguiram perceber. Neste item fez-se a opção de perguntas objetivas com uma única possibilidade de resposta, a fim de se evitar contradições. Os dados colhidos foram: A-Recebi ajuda e me senti segura 51 ; B - Recebi ajuda, me senti acolhida, mas não segura 57 ; C - Recebi ajuda, mas não me senti segura 22 ; D - Recebi ajuda e me senti parcialmente segura 37 ; E - Não recebi ajuda 38.

\section{DISCUSSÃO DOS RESULTADOS}

Os diferentes tipos de violências doméstica e familiar contra a mulher são estabelecidas na Lei Maria da Penha (Lei 11.340/06), que são: física, sexual, moral, patrimonial e psicológica. Hoje em dia, tais violências, principalmente as físicas e sexuais, são muito pautadas na mídia41 e, em vista do fato de que a Lei é derivada da condenação sofrida pelo Brasil na Corte Interamericana de Direitos Humanos, que apontou a completa omissão estatal no tocante à proteção de Maria da Penha Maia Fernandes, a qual sofreu inúmeras tentativas de feminicídio e que ficou paraplégica em decorrência das agressões perpetradas por seu marido (OEA, 2000), é nítida a mudança quanto a intenção de desnaturalizar as violências sofridas pelas mulheres.

Também houve a recente tipificação penal do feminicídio (Lei 13.104/15) e ainda que estas leis tenham sido importantes mudanças no cenário atual, são necessárias mais medidas preventivas e que não busquem no Direito Penal a única solução. E como visto as violências sofridas dentro de relacionamentos abusivos podem ser evitadas por medidas de conscientização do que são violências, visto que estas são naturalizadas nas relações íntimas e por ações que visem a proteção da mulher pelas vias administrativas das universidades.

A importância da pesquisa sobre relacionamentos íntimos abusivos reside no fato de que estas relações estão inseridas na lógica patriarcal e são naturalizadas, conquanto uma construção estrutural dos preceitos sociais e jurídicos ao longo de décadas. Embora na maioria dos países exista mais homicídios de homens do que de mulheres a situação se inverte na questão do homicídio de mulheres, o qual, majoritariamente é perpetrado por homens, com os quais essas mulheres se relacionam (MENEGHEL e PORTELA, 2017).

\footnotetext{
${ }^{41}$ Ao buscar o termo "violência contra a mulher" em veículos de grande circulação midiática, percebe-se a existência quase diária de ao menos uma reportagem sobre a temática. Foram consultados os veículos midiáticos G1 ; Veja.com; Estadão.com; BBC News Brasil e Uol.com.
} 
É importante ser abordado que embora seja possível perceber, pelos relatos, que existiram inúmeras situações de violência, essas mulheres possuem dificuldades em denominar os atos e fatos ocorridos com a denominação de violência. A título ilustrativo importa dizer que 9 mulheres declararam ter sido estupradas, 3 tiveram penetração forçada e 31 mulheres indicaram que foram "forçadas a fazer sexo", do que se pode observar a dificuldade em descrever uma situação de violência como tal, na medida em que o estupro e o sexo forçado são a mesma coisa. É possível perquirir que a própria dificuldade da mulher de se enxergar como vítima derive do fato de a sociedade, como um todo, não enxergue esses casos como uma situação de violência, dificultando-se a autopercepção do abuso.

Embora tenham usado vocábulos diferentes, essas mulheres experimentaram a mesma situação de agressão. Assim, de um universo de 500 mulheres, 43 delas, ou seja, 8,3\% sofreram algum tipo de violência sexual. Tal número se amplia quando se soma as que declararam que durante a relação 0 parceiro se recusou, ou, ainda, retirou o preservativo no meio do ato sexual, casos que constam 20 relatos a mais.

Há correntes doutrinárias que afirmam que a retirada do contraceptivo durante 0 ato sexual e sem a anuência da parceira seja considerado estupro e se assim é considerado, o número é aumentado bastante. $O$ problema reside no fato de que muitas mulheres sequer sabem que isso é uma violência ou que não a relatam, pois se referem à uma "intimidade" do casal, modificando a percepção que temos sobre as violências contra a mulher, as quais já possuem uma cifra oculta muito elevada.

Entende-se assim, que apesar de várias dessas violências possuírem provas materiais de sua ocorrência, ainda assim, persiste uma cultura jurídica permeada por discursos que visam desqualificar a palavra da vítima. Essa desqualificação foi construída por meio de diversas formas, seja indicando a moralidade da vítima, para averiguação de alguns crimes sexuais, fato somente abolido em 200542, seja pela argumentação de uma possível absolvição do marido, quando este utilizando-se do seu poder de "correção" perpetrava lesões corporais (FRANCO, 1987:passim.). Nesse mesmo sentido, convém indicar a recente notícia sobre a absolvição de um motorista de aplicativo que estuprou uma passageira que estava sob a influência de uso do álcool43.

\footnotetext{
${ }^{42}$ Cf. BRASIL. LEI № 11.106, DE 28 DE MARÇO DE 2005. Altera os arts. 148, 215, 216, 226, 227, 231 e acrescenta o art. 231-A ao Decreto-Lei no 2.848, de 7 de dezembro de 1940 Código Penal e dá outras providências. Disponível em http://www.planalto.gov.br/ccivil 03/ Ato2004-2006/2005/Lei/L11106.htm. Acesso em 06 set. 2019.

${ }^{43}$ Colaciona-se a notícia publicada no site jurídico Migalhas: "Conforme a denúncia, a mulher, ao acordar, percebeu que seu aparelho celular havia ficado com o motorista, que teria cobrado $\mathrm{R} \$ 50$ para devolvê-lo e perguntado se ela possuía alguma doença transmissível. A vítima
} 
Dos dados colhidos se percebeu que as violências moral e psicológica possuem uma recorrência no que se pode observar de uma construção de um relacionamento que prima por minar a autoestima da mulher, a fim de fazer com que a mulher questione seus pensamentos, sua beleza, sua atitude e, em alguns casos, até sua sanidade. Dentre os relatos há muitas mulheres que declaram ter sido alertadas por amigos e ou familiares, porém, experimentaram dificuldade em se reconhecer na posição de quem sofre a violência, algumas indicaram grupos feministas e outras apoio psicológico para sair da situação, mas são duas grandes problemáticas que devem ser o foco da questão: fazer com que a mulher perceba que está num relacionamento abusivo e fazer com que ela saia desse relacionamento.

Aqui, não se advoga pela questão de se tipificar tais violências, mas, principalmente, da necessidade da criação de mecanismos para que sejam prevenidas e mais facilmente identificáveis tanto pelas vítimas quanto pelos agressores, pois que ambos estão inseridos numa lógica que perpetua violências como naturais (SAFFIOTI, 2004). É importante traçar que além do direito penal, necessita-se de um projeto educativo de empoderamento das mulheres e de combate à masculinidade tóxica, pois não é necessária somente a (re)educação da vítima para perceber o abuso, como também é necessária a (re)educação da sociedade para reconhecer a relação enquanto violação de direitos e a (re)educação do agressor, para que entenda que a performance do masculino prescinde da manifestação de violência e posse sobre a mulher.

\section{PROPOSTAS ÀS UNIVERSIDADES}

também teria percebido lesões e dores em seu corpo, e se lembrava apenas de "flashes" da noite anterior. $O$ júzo de $1^{\circ}$ grau condenou o acusado a 10 anos de reclusão em regime fechado. Ele recorreu da sentença e requereu a absolvição, alegando insuficiência probatória.Ao analisar o caso, a relatora, desembargadora Cristina Pereira Gonzales entendeu que, pelo que se extrai dos depoimentos da vítima e do acusado, "a ausência de consentimento por parte da vítima, decorrente da impossibilidade de oferecer resistência (pela embriaguez) não ficou demonstrada". A magistrada elencou que a mulher admitiu o consumo de álcool, "o que ocorreu por sua livre e espontânea vontade", e que as testemunhas de acusação afirmaram que, em virtude de estar alcoolizada, ela não se encontrava bem, mas não referiram que o estágio etílico chegava a ponto de perder os sentidos. Para a relatora, o MP/RS não fez prova do estado de embriaguez da ofendida, "que a teria impossibilitado de oferecer resistência à investida do acusado, já que inexiste, nos autos, exame toxicológico que atestasse o nível de álcool no sangue da vítima ou o uso de qualquer outra substância". "Sem essa prova, é inviável afirmar que ela perdera a capacidade de resistência ao suposto ataque sexual, mormente porque a prova oral não é conclusiva a esse respeito." A magistrada pontuou que, "se a ofendida bebeu por conta própria, dentro de seu livre arbítrio, não pode ela ser colocada na posição de vítima de abuso sexual pelo simples fato de ter bebido"; e entendeu que o relato da vítima não se reveste de suficiente segurança ou verossimilhança para autorizar a condenação do acusado. Assim, por considerar que não há provas seguras para condenar o motorista, votou por absolvê-lo. O voto foi seguido à maioria pelo colegiado. "Assim, diante da ausência de elementos probatórios capazes de estabelecer o juízo de certeza, mormente no tocante à ausência de discernimento para a prática do ato ou da impossibilidade de oferecer resistência, indispensáveis para sustentar uma condenação, decido a favor do acusado, com fundamento no princípio do in dúbio pro reo."O processo tramita em segredo de Justiça. 
Primeiramente, é indispensável salientar o papel das universidades em relação a conscientização das e dos estudantes sobre como identificar um relacionamento abusivo e quais as violências que são usualmente perpetradas contra as mulheres, além de outras medidas a serem criadas por cada instituição em busca da proteção preventiva do direito das mulheres.

A pesquisa propõe também a necessidade da interferências das Universidades em relação às denúncias de relacionamento íntimos abusivos com vistas a criação de instrumentos administrativos que analisem os casos e que possuam alternativas, extrajudiciais, de proteção aos direitos da vítima.

Em vista de todo o exposto quanto a ocorrência de altos índices de relacionamentos íntimos abusivos sofridos pelas universitárias é mais que límpido o papel que as universidades têm na contenção de tais violências, visto que é um ambiente de conhecimento, profissionalização e que deve ser de livre e igual acesso a todos. E aqui a igualdade se refere a possibilidade de adentrar e frequentar esses espaços de forma segura e saudável, sem que essas mulheres estejam nesses lugares sendo ameaçadas e intimidadas por seus agressores.

A proposta visa também ser uma alternativa ao encarceramento, pois que muitas das violências relatadas pelas mulheres são crimes e, portanto, passíveis de prisão. Nessa mesma linha de pensamento para que as mulheres se direcionem em busca das Delegacias de Defesa da Mulher (PINCA, 2018) e para o Judiciário (SCARPATI, 2013), por exemplo, muitas destas mesmas mulheres só o fazem, se o fazem, quando as violências estão a níveis insustentáveis (vide nenhuma mulher ter procurado o Judiciário e as menores procuras terem sido para as Delegacias de Defesa da Mulher e advogados/as), já que são instituições opressoras e reprodutoras de discriminações e que, portanto, não são locais acolhedores a mulheres que estavam num relacionamento íntimo abusivo cujas complexidades não são entendidas nem analisadas pelos órgãos citados.

Em vista da dificuldade da mulher, vítima de violências praticadas por seu companheiro íntimo, conseguir medidas eficazes nas Delegacias de Defesa da Mulher e no Judiciário, ela acaba deixando de frequentar vários espaços, além de ficar desamparada. Isso cria a possibilidade, ou necessidade, de as universidades, administrativamente criarem mecanismos próprios de proteção às vítimas.

Este texto enfoca na atuação quanto aos relacionamentos íntimos abusivos em que as mulheres são vítimas, posto que são grande maioria, mas tais órgãos visam a proteção dos estudantes em situação de 
vulnerabilidade, podendo ser aplicada a outras discriminações como àquelas relacionadas à raça, à classe, à orientação sexual, entre outras.

É necessária também a inclusão nos conteúdos acadêmicos de novas perspectivas a fim de mitigar essas situações. Entre as medidas se inclui a promoção de eventos destinados à conscientização e combate à cultura patriarcal e de suas decorrentes violências (como o estupro, a relação sexual forçada sem o uso de contraceptivos, o beijo forçado, a perseguição, entre outros) e da masculinidade tóxica. É importante salientar que o machismo também traz imposições aos homens que são danosas à sua integridade, física, psicológica e mental, e que também repercutem neles, acarretando em mais violências.

Propõe-se, então além de palestras, a inclusão de disciplinas, ou ainda, de conteúdos que abarquem essa temática nos requisitos obrigatórios de horas extradisciplinares e, como já dito, impõe-se a criação de instrumentos pela universidade para salvaguardar o direito das mulheres, como um centro de acolhida às universitárias que estiveram em situação de relacionamento íntimo abusivo ou mecanismos institucionais para que a vítima e o agressor não estejam nos mesmos locais. Essa acolhida pode ser apresentada em vários níveis, desde um espaço para a escuta qualificada, até a possibilidade de afastamento das atividades escolares, para um período de distanciamento do agressor, ou o contrário se houver um processo administrativo com o devido contraditório.

Enumera-se então algumas ideias de ações que podem ser desenvolvidas pelas universidades: a criação de um espaço de acolhida, com profissionais, mulheres, habilitadas para a escuta e apoio psicológico; orientação jurídica, caso a estudante queira tomar medidas legais; criação de grupos de apoio e prevenção dentro dos câmpus, no qual, mediante identificação, a ser escolhida, mulheres possam ser referência de suporte em situações de violência; possibilidade de troca de turno a fim de evitar contato com agressor; possibilidade de afastamento das atividades acadêmicas, através da modalidade de estudo a distância, por períodos a serem apurados, a fim de que a mulher se restabeleça; a possibilidade de processos administrativos com ampla defesa que permitam que a universidade tome atitudes de maneira a possibilitar que a vítima frequente tais locais com o afastamento ou restrições por parte do agressor.

Impõe-se que essas medidas podem ser colocadas em prática mesmo que sem o ônus financeiro das instituições, porquanto as universidades já contam com a existência de profissionais aptos aos apoios, podendo apenas reestruturas certos profissionais ou modificar regulamentações acadêmicas, que já existem como possibilidade para outras situações de necessidade pessoal do aluno, as quais podem ser estendidas ao contexto da violência afetiva. 


\section{CONCLUSÕES}

As conclusões parciais foram que a violência de gênero no meio universitário se fez presente em aproximadamente 50\% das mulheres questionadas, com massiva incidência das formas psicológica, moral e sexual. Essas violências por não deixarem vestígios materiais, ou, no caso da violência sexual, experimentarem uma constante deslegitimação da palavra da vítima, são difíceis de provar, e, por consequência, incorre-se em um esvaziamento dos mecanismos jurídicos criados para o seu combate.

Foi perceptível que muitas mulheres buscaram mais ajuda através de redes de apoio, o que ainda será objeto de discussão mais ampla. Todavia, pode-se perceber que as redes de apoio informais se apresentam como a primeira opção de refúgio à essas mulheres, o que condiz com 0 distanciamento existente entre o Direito e suas esferas institucionais, tanto criminais quanto cíveis, e a população em geral. Ainda, cumpre ressaltar que a Universidade se mantém como mecanismo mais acessível que os meios jurídicos, o que mostra a importância de se ampliar o debate institucional sobre o combate à violência de gênero nesse ambiente.

Em próxima etapa os dados objetivos serão conjugado com os relatos apresentados a fim de se verificar quais os principais pontos de enfoque necessários para que as violências de gênero ocorridas no âmbito do ensino superior possam ser combatidas. Buscar-se-á a elaboração de estratégias extrajudiciais, como a construção de grupos de apoio ou redes de empoderamento, sem prejuízo da construção de uma cultura institucional de identificação e prevenção a essas violências, a fim de que estas mulheres possam ter a sua permanência no ensino superior como menores obstáculos em razão de seu gênero.

Cumpre ressaltar que a metodologia escolhida, tem como objetivo dar voz às mulheres que, por vezes, não se sentem, ou acolhidas, ou quando acolhidas, não encontram meios eficazes para sair da situação de violência. Assim, os relatos em primeira pessoa nos permitem vislumbrar as sutilezas contidas em cada uma das experiências, com a apuração de detalhes que, em um questionário objetivo, passariam despercebidos e que podem indicar soluções mais adequadas e permanentes à erradicação da violência de gênero nesse sistema social.

\section{REFERÊNCIAS}

ALBERTIM, Renata. MARTINS, Marcelo. Ciclo do relacionamento abusivo: desmistificando relação tóxicas. Trabalho apresentado no GP Semiótica e 
Comunicação, XVIII Encontro dos Grupos de Pesquisas em Comunicação, evento componente do $41^{\circ}$ Congresso Brasileiro de Ciências da Comunicação. Intercom- Sociedade Brasileira de Estudos Interdisciplinares da Comunicação $41^{\circ}$ Congresso Brasileiro de Ciências da Comunicação - Joinville - SC - 2 a 8/09/2018.

Disponível em: http://portalintercom.org.br/anais/nacional2018/resumos/R13-0301-1.pdf. Acesso em 03 set. 2019.

AZEVEDO. Maria Amélia. Mulheres Espancadas: A violência denunciada. São Paulo: Cortez, 1985.

BAPTISTA, Bárbara Gomes Lupetti. A pesquisa empírica no direito: Obstáculos e contribuições. Trabalho apresentado na 26a․ Reunião Brasileira de Antropologia, realizada entre os dias 01 e 04 de junho, Porto Seguro, Bahia, Brasil. Este paper é resultado de pesquisa promovida no âmbito do projeto PRONEX/CNPQ, iniciado em 2007. Disponível em: <http://www.abant.org.br/conteudo/ANAIS/CD_Virtual_26_RBA/grupos_de_trab alho/trabalhos/GT\%2016/Microsoft\%20Word\%20-

\%20ABA\%202008\%20A\%20pesquisa\%20emp\%C3\%ADrica\%20no\%20Direito. pdf > Acesso em 12 jul 2019.

BRASIL. LEI № 11.106, DE 28 DE MARÇO DE 2005. Altera os arts. 148, 215, 216, 226, 227, 231 e acrescenta o art. 231-A ao Decreto-Lei no 2.848, de 7 de dezembro de 1940 - Código Penal e dá outras providências. Disponível em http://www.planalto.gov.br/ccivil 03/ Ato2004-2006/2005/Lei/L11106.htm. Acesso em 06 set. 2019.

BRASIL. Lei no 11.340, de 7 de agosto de 2006. Lei Maria da Penha. Cria mecanismos para coibir a violência doméstica e familiar contra a mulher e dispõe sobre a criação dos Juizados de Violência Doméstica e Familiar contra a Mulher; altera o Código de Processo Penal, o Código Penal e a Lei de Execução Penal; e dá outras providências. Disponível em:

<https://www.planalto.gov.br/ccivil_03/_Ato2004-2006/2006/Lei/L11340.htm>. Acesso em: 03 maio 2019.

BORGES, Paulo César Corrêa; PINCA, Marcela Helena Petroni. Violência de gênero: a atuação da Delegacia de Defesa da Mulher nos crimes de estupro, na cidade de Franca. Revista de Derechos Humanos y Estudios Sociales, $\mathrm{n}^{\circ} \quad$ 20: jul. dez., 2018. Disponível em: http://www.derecho.uas/p.mx/Documents/Revista\%20REDHES/N\%C3\%BAmer o\%2020/Redhes20-09.pdf> Acesso em: 25 jan. 2019.

CADERNOS JURÍDICOS: Violência Doméstica. Escola Paulista da Magistratura. São Paulo, nº 38, jan.-abr, 2014.

CASIQUE, Leticia; FUREGATO, Antonia Regina Ferreira. Violência contra mulheres: reflexões teóricas. Rev. Latino-Am. Enfermagem, Ribeirão Preto , v. 14, n. 6, p. 950-956, Dec. 2006 . Available from $<$ http://www.scielo.br/scielo.php?script=sci_arttext\&pid=S0104-

$11692006000600018 \&$ Ing=en\&nrm=iso $>$. access on 06 Sept. 2019. http://dx.doi.org/10.1590/S0104-11692006000600018. 
CUNHA, Roberto Salles. Os novos direitos da mulher. São Paulo: Atlas, 1989.

DEWES, João Osvaldo. Amostragem em Bola de Neve e RespondentDriven Sampling: uma descrição dos métodos. Trabalho de Conclusão de Curso apresentado ao Instituto de Matemática Departamento de Estatística. UFRGS. Porto Alegre Dez, 2013. Disponível em: <https://www.lume.ufrgs.br/handle/10183/93246> Acesso em 12 jul 2019.

FUNDAÇÃO SISTEMA ESTADUAL DE ANÁLISE DE DADOS (SEADE). Um retrato da Violência Contra a Mulher, 2038 Boletins de Ocorrência. São Paulo: SEADE, 1987.

FRANCO, Alberto Silva. Et al. Código penal e sua interpretação jurispruenccial. 2 edição, rev. ampl. 2 tiragem. São Paulo: Revista dos Tribunais, 1987.

GOMES, Ingridd Raphaelle Rolim; FERNANDES, Sheyla C. S. A permanência de mulheres em relacionamentos abusivos à luz da teoria da ação planejada. Bol. - Acad. Paul. Psicol., São Paulo , v. 38, n. 94, p. 55-66, jan. 2018. Disponível em $<$ http://pepsic.bvsalud.org/scielo.php?script=sci_arttext\&pid=S1415711 X2018000100006\&lng=pt\&nrm=iso > . acessos em 06 set. 2019.

GOMES, Orlando. Direito privado: Novos Aspectos. Rio de Janeiro/São Paulo: Livraria Freitas Bastos, 1961.

GREGORI, Maria Filomena. Cenas e queixas: um estudo sobre mulheres, relações violentas e a prática feminista. São Paulo: Paz e Terra, 1993.

HIRECHE, Gamil Föppel El. FIGUEIREDO, Rudá Santos. HOMICÍDIO CONTRA A MULHER. Feminicídio é medida simbólica com várias inconstitucionalidades. 23 de março de 2015, 7h29. Disponível em: https://www.conjur.com.br/2015-mar-23/feminicidio-medida-simbolica-variasinconstitucionalidades Acesso em 06 set. de 2019.

LIMA, Camila Machado. O caso Maria da Penha no Direito Internacional. A pressão externa fomentando mudanças em uma nação. Publicado em 07/2017. Elaborado em 01/2016. Disponível em: <https://jus.com.br/artigos/58908/ocaso-maria-da-penha-no-direito-internacional> Acesso em 06 set. 2019.

MARQUES, Tânia Mendonça. Violência Conjugal: Um estudo sobre a permanencia da mulher em relacionamentos abusivos. (Orient.) Marília Ferreira Dela Coleta. Uberlândia: UFU, 2005. Disponível em: https://repositorio.ufu.br/bitstream/123456789/17261/1/TMarquesDISSPRT.pdf. Acesso em 06 set. 2019.

MENEGHEL, Stela Nazareth. PORTELLA, Ana Paula. Feminicídio: Conceito, tipos e cenários. Ciência \& Saúde Coletiva [online]. 2017, v. 22, n. 9. p. 3077- 
3086.

Disponível

em:

https://www.scielosp.org/scielo.php?script=sci arttext\&pid=S1413-

81232017000903077. Acesso em 06 set. 2019.

MIGALHAS. Motorista é absolvido de estupro por falta de prova do grau de embriaguez de passageira: Para a 5 $5^{\text {a }}$ câmara Criminal do TJ/RS, não ficou comprovada ausência de consentimento por parte da vítima. Quinta-feira, $1^{\circ}$ de agosto de 2019 . Publicado em quinta-feira, $1^{\circ}$ de agosto de 2019. Disponível em: $\quad$ https://www.migalhas.com.br/Quentes/17,MI307830,41046Motorista+e+absolvido+de+estupro+por+falta+de+prova+do+grau+de Acesso em 06 set. 2019.

SCARPATI, Arielle Sagrillo. Os mitos de estupro e a (im)parcialidade jurídica: a percepção de estudantes de Direito sobre mulheres vítimas de violência sexual. 2013. 201 f. Tese (Dissertação de Mestrado) - Universidade Federal do Espírito Santo, Vitória, 2013.

OLIVEIRA, Fabiana Luci de. Org. Justiça em foco: estudos empíricos. Rio de Janeiro: Editora FGV, 2012. 208 p. Disponível em: <https://bibliotecadigital.fgv.br/dspace/handle/10438/10358> Acesso em 12 jul 2019.

RUBIO. David Sanchez. CRÍTICA A UNA CULTURA ESTÁTICA Y ANESTESIADA DE DERECHOS HUMANOS. POR UNA RECUPERACIÓN DE LAS DIMENSIONES CONSTITUYENTES DE LA LUCHA POR LOS DERECHOS DERECHOS Y LIBERTADES. Número 33, Época II, junio 2015, p. 99 - $133 . \quad$ Disponível em: archivo.uc3m.es/bitstream/handle/10016/24125/DyL-2015-33sanchez.pdf?sequence=1. Acesso: 23 ago. 2019.

OEA - Organização dos Estados Americanos. COMISSÃO INTERAMERICANA DE DIREITOS HUMANOS. RELATÓRIO ANUAL 2000. RELATÓRIO N 54/01. CASO 12.051 - MARIA DA PENHA MAIA FERNANDES. BRASIL - 4 de abril de 2001. Disponível em: https://www.cidh.oas.org/annualrep/2000port/12051.htm. Acesso em 06 set. 2019

PAES, Fabiana. MP NO DEBATE: Criminalização do feminicídio não é suficiente para coibi-lo. 18 de março de 2019, 8h00. Disponível em: https://www.conjur.com.br/2019-mar-18/mp-debate-criminalizacao-feminicidionao-suficiente-coibi-lo. Acesso em 06 set. 2019.

PEREIRA, Elisângela S. PEREIRA, Daysimar S. Feminicídio - lei no 13.104, de 9 de março de 2015. Feminicídio no Brasil: estatísticas mostram que brasil é o quinto país que mais matam mulheres. Publicado em 11/2017. Elaborado em 11/2017. Disponível em :https://jus.com.br/artigos/62399/feminicidio-lei-n13-104-de-9-de-marco-de-2015. Acesso em 06 set. 2019.

SAFFIOTI, Heleieth lara Bongiovani. Gênero, patriarcado, violência. São Paulo: Fundação Perseu Abramo, 2004. 
[1] SEADE, 1987.

[2] A metodologia elegida permite que seja feito o acesso à populações cuja identificação a priori seria mais difícil, em virtude de os sujeitos da pesquisa não possuírem interesse em serem identificados. Leva-se em conta que a análise utilizada não pode constituir um retrato estatístico fiel, porém, pode trazer uma análise quantitativa que de outros métodos de percepção restariam não alcançados. (DEWES, 2013).

[3] APHONSIANO, CASPER LIBBERO, CESFJ - Argentina, CEUNSP, CLARETIANO, ESPM, FACON, Faculdade Guairacá, Faculdade Sumaré, Faculdade Vale do Cricaré, FAEMA, FAFIRE, FASI, FATEC, FDF, FDSBC, FGV, FIG, FMU, FUMEC, IBMR, IESP, Multivix, PUC, São judas Tadeu, SENAC, SIT - JAPÃO, UAM, UBC, UCR, UDESC, UEC, UEL, UEM, UEMG, UEMS, UEPG, UERJ, UFABC, UFBA, UFC, UFCG, UFF, UFFS, UFG, UFGD, UFJF, UFMG, UFMS, UFPA, UFPB, UFPE, UFPEL, UFPR, UFRGS, UFRJ, UFRN, UFRPE, UFRRJ, UFS, UFSC, UFSCAR, UFSJ, UFSM, UFTM, UFU, UNAERP, UNB, UNCISAL, UNESA, UNESP, UNESPAR, UNIAVEIRO - Portugal, UNIARA, UNIARARAS, UNICAP, UNICEP, UNICID, UNIDERP, UNIFAL, UNIFEI, UNIFESP, UNIFOR, UNIFRAN, UNIMEP, UNIMES, UNIMONTE, UNINNOVE, UNIOESTE, UNIP, UNIPAM, UNIS, UNISANTA, UNISANTOS, UNISINOS, UNISUAM, UNIUBE, Université Sorbonne Paris Cité - França, UNIVESP, UNOESC, UNOESTE, UNOPAR, USF, USP, UTFPR.

[4] AL; BA; CE; DF; ES; GO; MG; MS; PB; PE; PR; RJ; RN; RO; RS; SC; SE; SP.

[5] Argentina, Brasil, França, Japão e Portugal.

[6] A sociedade não está socializada com o Direito, não conhece as suas regras e, por conseguinte, não legitima as suas práticas. Entendo que uma forma viável de minimizar essa distância que separa o que deveria estar próximo, por ser complementar - os Tribunais e a sociedade - é tornar conhecidos e explícitos os rituais judiciários. (BAPTISTA, 2008: p. 04). 


\section{ÍNDICE}

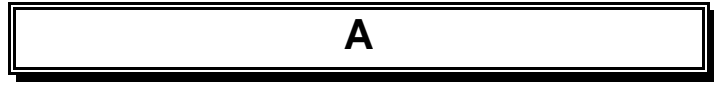

ALMEIDA JUNIOR, Silvio de, 36 ANDRADE, Lucimary Bernabé Pedrosa de, 27

\section{B}

BARBOSA, Marcela Dias, 121, 131

BATISTA, Evelyn Riola, 78

BORGES, Cintia Ceosane de Paula, 107

BULGO, Danilo Cândido, 36

\section{C}

CAMARGO, Carmen Aparecida

Cardoso Maia, 107

CAMPOS, Guilherme Pires de, 180 COSTA, Denise Gisele Silva, 68, 145

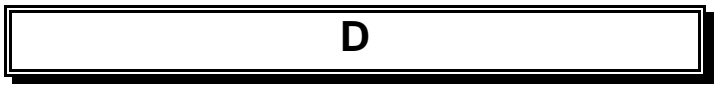

DONIZETTE, Lidiane Cristina, 27

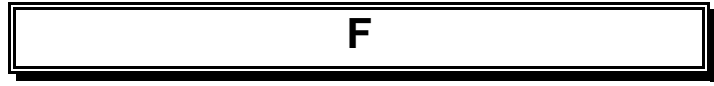

FARIA, Rafael Emilio, 133

FONSECA, Genaro Alvarenga, 9, 78

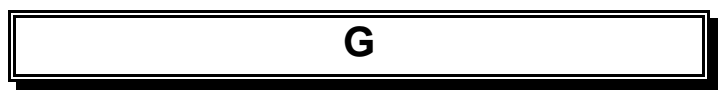

GARREFA, Fernando, 45

GRACIOLI, Maria Madalena, 88, 143

\section{M}

MARCICO, Bianca, 194

MARINHO, Isabella de Paula, 107
MARTINO, Vânia de Fátima, 133, 143

MATTAR, Jane Borges Lemos, 68 MESSIAS, Rosilene de Fátima

Rocioli, 55

MOHERDAUI, Isabela Cintra, 88

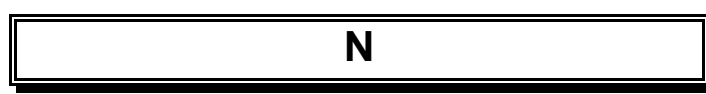

NASCIMENTO, Mari Clair Moro, 167

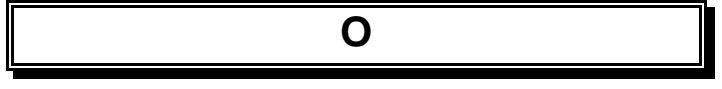

OLIVEIRA, Anelise Martinelli

Borges, 167

OLIVEIRA, Leticia Natália de, 36

\section{$\mathbf{P}$}

PINCA, Marcela Helena Petroni, 194, 205

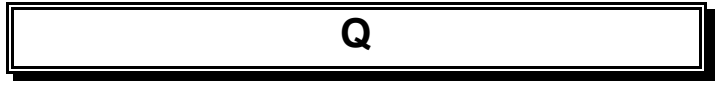

QUEIROZ, Adriana de Souza Lima, 68

\section{$\mathbf{R}$}

REIS, Lauane Silva, 145 ROSA, Lilian Rodrigues de Oliveira Rosa, 180

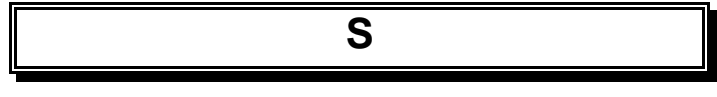

SILVA JUNIOR, Adolfo Domingos da, 9

SILVA, Márcia Pereira da, 157

SOUZA, Letícia de Paula, 45

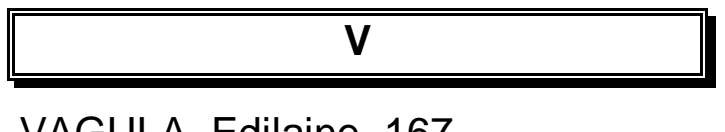

VAGULA, Edilaine, 167 

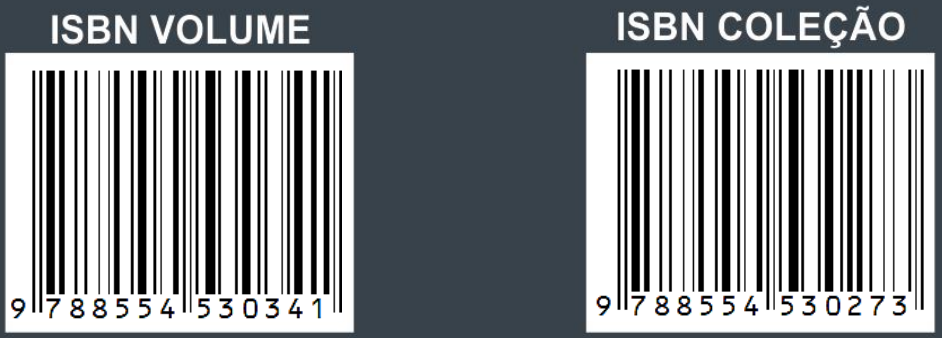

\section{8 | 163713.4688 unifacef.com.br | f}

163706.8700 franca.unesp.br 